Florida International University FIU Digital Commons

4-26-2013

\title{
"To Hold the World in Contempt": The British Empire, War, and the Irish and Indian Nationalist Press, 1899-1914
}

Susan A. Rosenkranz

srose002@fiu.edu

DOI: $10.25148 /$ etd.FI13080503

Follow this and additional works at: https://digitalcommons.fiu.edu/etd

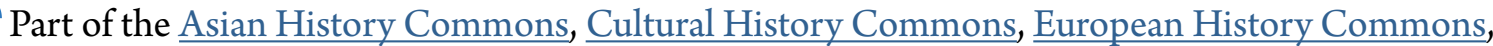
Film and Media Studies Commons, Journalism Studies Commons, Mass Communication Commons, Military History Commons, Political History Commons, and the Social History $\underline{\text { Commons }}$

\section{Recommended Citation}

Rosenkranz, Susan A., "'To Hold the World in Contempt": The British Empire, War, and the Irish and Indian Nationalist Press, 1899-1914" (2013). FIU Electronic Theses and Dissertations. 895.

https://digitalcommons.fiu.edu/etd/895 


\title{
FLORIDA INTERNATIONAL UNIVERSITY \\ Miami, Florida
}

\section{“TO HOLD THE WORLD IN CONTEMPT”: THE BRITISH EMPIRE, WAR, AND THE IRISH AND INDIAN NATIONALIST PRESS, 1899-1914}

\author{
A dissertation submitted in partial fulfillment of \\ the requirements for the degree of \\ DOCTOR OF PHILOSOPHY \\ in \\ HISTORY \\ by
}

Susan Ann Rosenkranz

2013 
To: Dean Kenneth G. Furton

College of Arts and Sciences

This dissertation, written by Susan Ann Rosenkranz, and entitled "To Hold the World in Contempt": The British Empire, War, and the Irish and Indian Nationalist Press, 18991914 , having been approved in respect to style and intellectual content, is referred to you for judgment.

We have read this dissertation and recommend that it be approved.

$\begin{array}{r}\text { Gwyn Davies } \\ \hline \text { Jenna Gibbs } \\ \hline \text { Meri-Jane Rochelson } \\ \hline \text { Rebecca Friedman, Major Professor }\end{array}$

Date of Defense: April 26, 2013

The dissertation of Susan Ann Rosenkranz is approved.

\begin{tabular}{r}
\hline $\begin{array}{r}\text { Dean Kenneth G. Furton } \\
\text { College of Arts and Sciences }\end{array}$ \\
\hline Dean Lakshmi N. Reddi \\
University Graduate School
\end{tabular}

Florida International University, 2013 
(C) Copyright 2013 by Susan Ann Rosenkranz

All rights reserved. 


\section{DEDICATION}

To my wonderful parents, Mike and Sylvia, and my beautiful sister, Lanie: None of this would be possible without the magical gift of each of you in my life. You shared with me your passion for knowledge and you taught me to dream. Everything I am, everything I have achieved, everything I hope to be is only possible because of your support, your friendship, and, especially, your love. 


\section{ACKNOWLEDGMENTS}

I would like to express my sincere and lasting gratitude to the members of my unrivaled dissertation committee for giving so generously of their time and talent, and sharing their unique insights with me. My thanks to Professor Gwyn Davies for his excellent and well-timed suggestion that I narrow my focus to coverage of imperial wars; to Professor Jenna Gibbs for her invaluable assistance in framing the central argument; to Professor Meri-Jane Rochelson for ensuring that the narrative flowed and was accessible to non-historians; to Professor Michael Brillman, for his spirited encouragement and for guaranteeing the integrity of my Indo-Irish scholarship; and to the Chair of my committee, Professor Rebecca Friedman, for her calm, splendid guidance, emphasis on the big picture, and unflagging support. Finally, I would like to thank my personal proofreader - my father-for all the late night editing sessions to which he so gallantly and cheerfully submitted. 
ABSTRACT OF THE DISSERTATION

“TO HOLD THE WORLD IN CONTEMPT:” THE BRITISH EMPIRE, WAR, AND

THE IRISH AND INDIAN NATIONALIST PRESS, 1899-1914.

by

Susan Ann Rosenkranz

Florida International University, 2013

Miami, Florida

Professor Rebecca Friedman, Major Professor

The era between the close of the nineteenth century and the onset of the First World War witnessed a marked increase in radical agitation among Indian and Irish nationalists. The most outspoken political leaders of the day founded a series of widely circulated newspapers in India and Ireland, placing these editors in the enviable position of both reporting and creating the news. Nationalist journalists were in the vanguard of those pressing vocally for an independent India and Ireland, and together constituted an increasingly problematic contingent for the British Empire. The advanced-nationalist press in Ireland and the nationalist press in India took the lead in facilitating the exchange of provocative ideas — raising awareness of perceived imperial injustices, offering strategic advice, and cementing international solidarity.

Irish and Indian press coverage of Britain's imperial wars constituted one of the premier weapons in the nationalists' arsenal, permitting them to build support for their ideology and forward their agenda in a manner both rapid and definitive. Directing their readers' attention to conflicts overseas proved instructive in how the Empire dealt with 
those who resisted its policies, and also showcased how it conducted its affairs with its allies. As such, critical press coverage of the Boxer Rebellion, Boer War, Russo-Japanese War, and World War I bred disaffection for the Empire, while attempts by the Empire to suppress the critiques further alienated the public.

This dissertation offers the first comparative analysis of the major nationalist press organs in India and Ireland, using the prism of war to illustrate the increasingly persuasive role of the press in promoting resistance to the Empire. It focuses on how the leading Indian and Irish editors not only fostered a nationalist agenda within their own countries, but also worked in concert to construct a global anti-imperialist platform. By highlighting the anti-imperial rhetoric of the nationalist press in India and Ireland and illuminating their strategies for attaining self-government, this study deepens understanding of the seeds of nationalism, making a contribution to comparative imperial scholarship, and demonstrating the power of the media to alter imperial dynamics and effect political change. 


\section{TABLE OF CONTENTS}

CHAPTER

PAGE

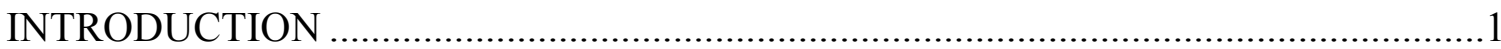

I. “AN INSURRECTION IN PRINT”: THE PRESS AND THE BRITISH EMPIRE ..20

II. “A SMALL GUST OF WIND”: THE BOER WAR_...................................................68

III. “PERDITION TO PIGTAILS”: THE BOXER REBELLION ....................................118

IV .“CONSCIENCE HAS LOST ITS HOLD”: THE BOER WAR REDUX ...................163

V. “COMMON CAUSE, COMMON ACTION”: WAR AND ALLIANCE .................212

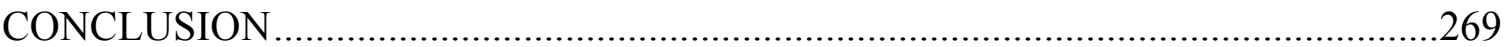

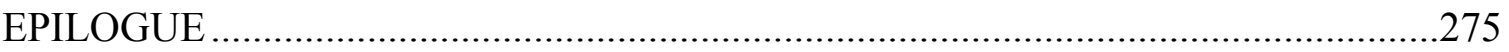

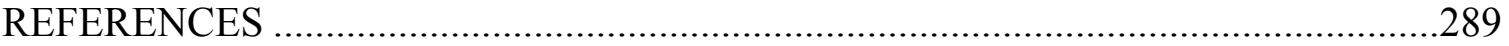

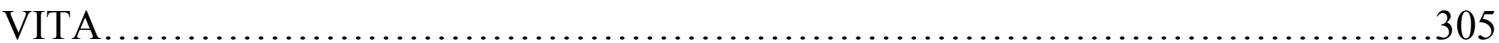




\section{$\underline{\text { Introduction }}$}

The British Empire was at its zenith - a marvel of modernity and a model of efficiency, confounding the world with its ability to colonize, civilize, and organize. British troops marched in formation across desert, mountain, and plain, the sound of their polished boots echoing from Sandhurst to the Hindu Kush. ${ }^{1}$ British missionaries fanned out across Africa and Asia, proselytizers determined to convince and convert, while a non-stop parade of civil servants—-sufficiently civilized and servile—classified and categorized all things imperial. The envy of its rivals, Britain held dominion over the seas and dominated world trade, its factories alive with the hum of machinery and the soothing clink of profits. Railway and steamship made possible the smooth transportation of men and horses, guns and goods, all heading to the next site of conquest or point of resistance.

It was the uninterrupted transmission of information, however, that transformed the Empire into a paragon of proficiency. Snaking under the ocean and strung across vast continents was a network of telegraph cables - the arteries of the Empire-carrying news to and from Britain, linking colony and settlement, territory and town. That splendid conduit of information not only helped maintain the efficiency of the Empire, but also fueled the rapid growth of the press — serving as a lifeline for journalists, now capable of relaying to their readership in Britain timely news of discovery, expansion, resistance, and war.

\footnotetext{
${ }^{1}$ The Royal Military Academy Sandhurst has been the training ground of British Army officers since 1813 .
} 
For Britain's restless subjects in Ireland and India, access to that information would prove invaluable. The years between the close of the nineteenth century and the onset of the First World War witnessed a marked increase in radical political agitation among nationalists in Ireland and India. Irish and Indian journalists were in the vanguard of those crusading vocally for self-government, and together constituted an increasingly problematic contingent for the British Empire. The nationalist press in India and Ireland facilitated the exchange of provocative ideas - in the process raising awareness of perceived and real imperial injustices, offering strategic advice to each other, and cementing international solidarity. The British Empire, reeling from an embarrassing setback in the aftermath of the Jameson Raid in South Africa, and facing intensified rivalries from Russia and Germany, found itself under sustained assault from its own Irish and Indian subjects, who relentlessly drove home their advantage. ${ }^{2}$ The dissertation argues that Irish and Indian press coverage of Britain's imperial wars constituted one of the premier weapons in the nationalists' arsenal, permitting them to build support for their ideologies, forward their agendas both rapidly and definitively, and help precipitate the waning of the British Empire.

For a country that had long boasted of its liberalism, the British tradition of freedom of the press was more than a badge of honor; it was a defining characteristic. The British newspaper was not merely a chronicler of events. It was prima facie evidence that in the British Empire words were a valuable currency and public opinion

\footnotetext{
${ }^{2}$ The 1895 Jameson Raid was a failed attempt by Leander Starr Jameson to rouse British workers (uitlanders) in Johannesburg and convince them to participate in an uprising that would overthrow Paul Kruger's government, which discriminated against uitlanders. Immediately following the raid, Kaiser Wilhelm sent Kruger a telegram congratulating him on thwarting the uprising. The Jameson Raid and the subsequent telegram exacerbated what was already significant tension between Kruger's government and Britain, and became significant factors in the buildup to the Second Boer War (1899-1902).
} 
mattered. The press embodied the principle of free speech - giving a voice to the masses, and offering a channel through which even the lowliest citizen could step up in class and speak truth to power. Throughout the nineteenth century, wherever the Empire annexed new territories, the press staked its own claim — as British as the bible and the bayonet, and often just as effective in winning over hearts and minds. With the advent of the telegraph cable, those at home in the metropole could share in the expansion of the Empire, vicariously taking up the white man's burden, and taking pride in being a member of a British race that could conquer and control—with such a seemingly light touch.

It was, of course, part and parcel of British policy to extend many of the same freedoms to the newly subjugated, ensuring that they understood the advantages of exchanging their national identity in favor of donning the imperial mantle. Freedom of speech and freedom of the press were olive branches - mitigating factors in the loss of one's land or religion. What did not seem to occur to the British emissaries in the first flush of conquest is that those who were so easily dominated might one day wish to appropriate the tradition of a free press to further their own nationalist ends. If the Empire could use the press to infuse its citizens with a felicitous sense of British-ness, what was to stop nationalist journalists in Ireland and India from instilling their readers with a bold sense of Irish and Indian identity?

Of enormous significance to the Irish and Indian nationalist movements was the fact that the most outspoken political leaders of the day also founded and edited a series of widely circulated newspapers in India, Ireland, and America. As a result, nationalist editors were in the unique and enviable position of being able not only to report the news, 
but also to make the news. Under the guidance of editors such as Bal Gangadhar Tilak (Mahrátta, Kesari), Surendranath Banerjea (Bengalee), and Shivram Mahadev Paranjape (Kál) in India, and Arthur Griffith (United Irishman, Sinn Féin), James Connolly (Workers' Republic), and D.P. Moran (The Leader) in Ireland, as well as the exiled Irishman John Devoy (Gaelic-American) in America, nationalists launched and sustained an orchestrated campaign against the British Empire. The press became a primary tool for spreading what the Government of India and many in the British Parliament characterized as incendiary ideas.

By the period in question, the newspaper had become far more than a literary organ; it was a respected social and cultural instrument capable of framing the conversation and persuading public opinion. Whereas the Indian National Congress and the Irish Parliamentary Party were actively pursuing constitutional means to achieve some form of Home Rule, the fact that the two bodies were composed primarily of the educated elite made it difficult to expand their appeal to the general public. Politicians made pronouncements for the benefit of other politicians, but it was the press that spoke to the masses, seeking to galvanize support for the nationalist cause.

The nationalist press both in Ireland and India moved into the ascendancy by understanding and exploiting its ability, as well as the need, to reach both domestic and global audiences. Not content to limit themselves to provincial news, the leading nationalist organs of the Indian and Irish press were comprehensive in their coverage of national and international trends and events. They regularly published articles and editorials from foreign newspapers in the pages of these nationalist newspapers, reminding readers that their struggle was shared by imperial subjects around the world 
and urging solidarity. The foremost editors of the Indian and Irish press, moreover, were writing not merely for their domestic readership, but also for an international audience, in an attempt to underscore the hypocrisy of British rule and thereby attract support for their nationalist cause.

The fifteen-year period between 1899 and 1914 proved to be particularly fertile ground for nationalist journalists, as the British Empire found itself embroiled in no fewer than three significant wars. Britain deployed troops in the Boxer Rebellion in China (1899-1901), the Second Boer War in South Africa (1899-1902), and the First World War (1914-1918) — while the Russo-Japanese War (1904-1905) compelled an ostensibly neutral Britain to form strategic international alliances. The Irish and Indian focus on imperial wars not only highlighted flaws in military strategy, but also brought into sharp relief the often heavy-handed, short-sighted tactics with which Britain attempted to control its colonial subjects. Irish and Indian nationalist editors took advantage of these unrivaled opportunities to unload a blistering critique of policies they deemed incomprehensible, while simultaneously offering a resounding rejection of conditions to which they would never become reconciled.

By covering the conflicts and commenting on the political marriages of convenience that these conflicts generated, nationalist editors in India and Ireland could provide instruction not only on how the Empire dealt with those who resisted its policies, but also how it conducted its affairs with its allies. Nationalist journalists also exploited every opportunity to highlight the methods of others engaged in the struggle for independence. Thus, canny Irish editors directed the attention of their readership not only to the plight of the Boxers and the Boers, but also to the Empire's treatment of India. 
For their part, resourceful Indian editors looked beyond their borders not only to China and South Africa, but also to the shores of Ireland, where the quest for self-government served as an example for their own readers to emulate.

That Ireland and India should find such common cause seems implausible, if not improbable. By most measures, the Emerald Isle and the Indian subcontinent bore little resemblance to each other, with India dwarfing Ireland both in terms of size and population. When the British turned their gaze half way around the world to India, they saw not the familiar, recognizable white-skinned, English-speaking Catholics and Protestants of Ireland, but dark-skinned Hindus, Muslims, Buddhists, and Jains, speaking more than fifteen different languages and 1650 dialects. $^{3}$ Moreover, Britain's historic relationships with the two countries were materially different. The British had begun intervening in Ireland in 1170 and in the following seven hundred years British authorities had outlawed the Irish language, attempted to marginalize the Catholic religion, banished the Irish to the rockiest and least hospitable outposts of the country, disenfranchised all but the wealthiest property owners, charged exorbitant rents to tenants, and done little or nothing to ameliorate abject poverty and hunger.

By contrast, Britain's direct governing of India did not begin until after the Indian Mutiny of 1857 . The relatively brief period of governance presented a unique set of challenges for which the long reign in Ireland did not remotely prepare the Empire. . Confronted with myriad problems stemming from dissimilarities of language, religion, and custom, Britain found itself perpetually stymied by the enigma that was India.

\footnotetext{
${ }^{3}$ The number of languages and dialects spoken on the subcontinent in any given era is a source of continuing debate, with some scholars placing the number of dialects closer to two thousand. The Constitution of India currently recognizes twenty-two scheduled languages, as well as two hundred mother tongues.
} 
Intrusive and insensitive legislation designed to control the plague, condescending directives concerning native troops, and well-meaning but paternalistic attempts to provide British education revealed the Empire at its most maladroit. As the new century dawned, moreover, one of the most glaring contrasts between Ireland and the subcontinent was the presence of a sizable number of Irish representatives in Parliament, while the British Government barred India from representation. ${ }^{4}$

Despite the seeming disparities, Ireland and India underwent strikingly similar national experiences during their contemporaneous progress toward independence. Neither country was a stranger to land agitation, while famine brought devastation to Irish and Indian peasants alike. The question of a national language preoccupied both India and Ireland, just as the quest to regain a lost national heritage consumed their leaders. Sectarian strife rent the fabric of both nations, ensuring that independence would be won only at the cost of partition. Moreover, when enacting press legislation, British authorities often elected to ignore the considerable differences between Ireland and India, and view their inhabitants through a seemingly identical lens. No accident of history

\footnotetext{
${ }^{4}$ Given the example Ireland would one day set in breaking free from the Empire's bonds, it is notable that Ireland played a substantial role in Britain's governing of the subcontinent. Historian T.G. Fraser estimated that forty percent of the British Army was recruited from Ireland during the nineteenth century. T.G. Fraser, "Ireland and India," in An Irish Empire? Aspects of Ireland and the British Empire, ed. Keith Jeffery (Manchester: Manchester University Press, 1996), 77. At the height of the British Raj, in the second half of the nineteenth century, Irish sons seeking promotion filled the ranks of the Indian army and the Indian Civil Service, while Irish Protestant missionaries traveled the subcontinent, preaching and proselytizing. Among those appointed viceroys of India, several were of Irish or Anglo-Irish ancestry, including Lord Canning (1858-1862), Lord Mayo (1869-1872), Lord Dufferin (1884-1888), and Lord Lansdowne (1888-1894) In the revolving door that was the British imperial administration, Viscount Morley twice served as Chief Secretary of Ireland $(1886,1892-95)$ before his appointment as India's Secretary of State (1905-1910), while the Catholic Sir Antony MacDonnell of County Mayo spent thirtysix years in the Indian Civil Service, only to return in 1902 as Under Secretary for Ireland. Among MacDonnell's many posts in India were that of accountant general and revenue secretary for Bengal, and Lieutenant Governor of the North-West Provinces (1895-1901). See M.L. Brillman, "A Crucial Administrative Interlude: Sir Antony MacDonnell's Return to Ireland, 1902-1904," in New Hibernia Review, Volume 9, Number 2 (Summer 2005), 65-83.
} 
compelled India and Ireland to consider each other brothers-in-arms; their very inclusion in the monolith that was the British Empire forged a link between the two countries. ${ }^{5}$

They interacted in ways that were both subtle and dynamic, with Westminster acting as a catalytic agent.

As India inched ever closer to independence, the measures enacted by its leaders would increasingly mirror the Irish paradigm, finding in Ireland a framework for nationalist thought and deed. The paths of Irish and Indian nationalists crossed directly on three separate and distinct occasions. Marked by agrarian strife and parliamentary skirmishes, the Irish Land War and Home Rule movement of the 1870s and 1880s clearly influenced the evolution of the Indian National Congress, established in 1885. Fiery rhetoric, direct action, and an appeal to national pride characterized the early years of the twentieth century, during which the Sinn Féin and Swadeshi movements developed simultaneously in 1904-05. ${ }^{6}$ Finally, the Easter Rebellion of 1916 heralded the most combustible stage of contact between Irish and Indian nationalists. During this volatile and violent era, key factions in Ireland and India shifted to a program of physical force and terrorism. ${ }^{7}$

Given the contacts between Ireland and India that spanned more than a century, it is remarkable that scholarship on this connection has been slow to develop. Pairing India

\footnotetext{
${ }^{5}$ Fraser suggests that without the existence of the British Empire, "there would have been little, if anything, to unite the fortunes of Ireland and India." Fraser, 77.

${ }^{6}$ To avoid confusion between the Sinn Féin political movement and Arthur Griffith's Sinn Féin newspaper, only the name of the newspaper is in italics.

${ }^{7}$ For Indian police records documenting the importation of physical force tactics from Ireland, see Amiya K Samanta,., Ed. Terrorism in Bengal: A Collection of Documents on Terrorist Activities from 1905-1939. Six Volumes. (Calcutta: Government of West Bengal, 1995).
} 
and Ireland in historical studies has been a fairly recent phenomenon. The advent of Indo-Irish scholarship dates back fewer than fifty years, to the work of John V. Crangle, whose work charts the links between Irish Home Rulers and Indian nationalists, and Mary Cumpston, who provides evidence that the connection was detrimental to India's cause, as the disruptive tactics of the Irish Parliamentary Party alienated other members in the House. ${ }^{8}$ In the vanguard of those analyzing the press, Richard Davis notes how Irish editors pointedly invoke India's struggle as a source of inspiration for the Irish rebels, and chronicles how the shifting of public opinion in India reflected Irish tactics of obstruction, abstention, and escalating violence. ${ }^{9}$ Together with Davis, historian Howard Brasted deserves the lion's share of the credit for transforming Indo-Irish history into a fruitful sub-field, identifying "British sensitivity," "Irish initiative," and "Indian observation" as three dynamics that defined the complex relationship between India and Ireland-tropes that fuel Indo-Irish research to this day. ${ }^{10}$

\footnotetext{
${ }^{8}$ John V. Crangle, "Irish Nationalist Criticism of the Imperial Administration of India (1880-1884) in the Quarterly Review of Historical Studies, No. 4 (1971/72), 189-94; Mary Cumpston, "Some Early Indian Nationalists and Their Allies in the British Parliament, 1851-1906" in the English Historical Review, Vol. 76, No. 299 (Apr., 1961), 279-97.Chief among the Irish activists were Charles Stewart Parnell, Alfred Webb, and Michael Davitt. These and other Irish parliamentarians frequently voted in a bloc to approve such measures as famine relief and the rectifying of abuses in Indian administration.

${ }^{9}$ Richard Davis, "India in Irish Revolutionary Propaganda." Journal of the Asiatic Society of Bangladesh. Volume XXII, No. 1, April 1977, 66-89. Davis asserts that the Partition of Bengal, the passage of the oppressive Rowlatt Acts, and particularly the massacre of three hundred seventy-nine Indians at Amritsar proved even more valuable to the propagandists, particularly in the years following the 1916 Rebellion. Davis also explores India's native press, seeking to assess the impact of the Easter Rising on the Indian nationalist movement. Though India's leaders initially recoiled at the ruthlessness of the Easter Rebellion, Davis suggests that the defeat of the Irish Parliamentary Party by the more militant Sinn Féin Party in 1918 lent legitimacy to the cause of the Extremist wing in the Indian National Congress. Richard Davis, "The Influence of the Irish Revolution on Indian Nationalism: The Evidence of the Indian Press, "1916-22 in South Asia, Vol. 9, No. 2 (1986), 55-68.

${ }^{10}$ Howard Brasted, "Indian Nationalist Development and the Influence of Irish Home Rule, "in Modern Asian Studies, Vol. 14, No. 1 (1980), 37-63 and "Irish Models and the Indian National Congress, 18701922." South Asia, Vol. 8. No. 1-2 (1985). 24-45. Brasted contends that it was the reactionary policies of the British Government, not merely imported ideas from Ireland, which propelled the vessel of Indian
} 
In the 1990s, the field of Indo-Irish studies deepened, becoming more complex and more contentious. Historian S.B. Cook coined the term "intra-imperial analogies" to explain not only the tendency of scholars to draw comparisons between India and Ireland, but also the propensity of the British Government to effect a connection in matters of policy—-particularly legislation regarding the press. ${ }^{11}$ In matters of law and order, Britain looked frequently to Ireland for a suitable template that could be adapted to India, a practice that Cook notes often proved disastrous, as in the 1878 Vernacular Press Act and the Rowlatt Acts of $1919 .{ }^{12}$

Regardless of the connections identified by previous scholars, T.G. Fraser warns against the tendency of historians to read too much into the relationship. Fraser asserts that Irish willingness to resort to violence and extremism served only to alienate India's leaders, convincing them that the Irish paradigm would ultimately prove impractical for the Indian people. ${ }^{13}$ Whereas Fraser is correct in characterizing the more moderate element in India as unwilling to follow the Irish example of physical force, police records make clear that Indian revolutionaries employed what officials referred to as Irish Sinn Féin methods. Given that the figure of Gandhi has long dominated the field of South

nationalism, and notes that Ireland's course frequently served more as a cautionary tale to India than a salutary example.

${ }^{11}$ S.B. Cook, Imperial Affinities: Nineteenth Century Analogies and Exchanges Between India and Ireland.( New Delhi: Sage Publications, 1993). Cook points to Sir Charles Napier's use of an Irish model to organize the Indian police in the 1840s, as well as Viceroy Lord Minto's adaptation of existing Irish criminal law into the Indian Criminal Law (Amendment) Act of 1908 as examples of more successful adaptations. Cook further offers evidence that Irish land legislation, with its focus on the three F's of Fair rent, Fixity of tenure, and Freedom of sale, provided the pattern for the Bengal Tenancy Act of 1885.

${ }^{12}$ See Chapter One "The Press and the British Empire" for more on the connection between the 1870 Peace Preservation (Ireland) Act and the 1878 Vernacular Press Act, enacted in India.

${ }^{13}$ T.G. Fraser, "Ireland and India," in An Irish Empire? Aspects of Ireland and the British Empire, ed. Keith Jeffery (Manchester: Manchester University Press, 1996), 77-93. 
Asian studies, it is perhaps not surprising that more studies have focused on Indian nonviolence and passive resistance than Indian extremism and terrorism. Michael Silvestri is one of the few who explores the darker side of the Indo-Irish relationship, producing scholarship on the pervasive influence of the Irish Revolutionary movement. ${ }^{14}$ Whereas acts of terrorism had taken place at the time of the Partition of Bengal in 1905, Silvestri asserts that a coordinated program of attacks was not in evidence in India until a parallel shift transpired in Ireland. ${ }^{15}$

Despite historian T.G. Fraser's charge that his peers are exaggerating the IrelandIndia connection, his warning has gone unheeded, as historical interest in Indo-Irish scholarship heightens. Whether the Ireland-India affinity was real and tangible or merely a matter of historical coincidence was a question debated by attendees of the Fourth Annual Conference on Colonialism, hosted by the National University of Ireland at Galway in June 2004. While some historians in attendance appeared loath to attribute similarities between Ireland and India to anything other than complementarity, others saw evidence of a viable relationship. ${ }^{16}$ Out of that conference emerged the next wave of Indo-Irish scholarship, with several of the presenters publishing monographs. ${ }^{17}$

\footnotetext{
${ }^{14}$ Michael Silvestri, "The 'Sinn Féin of India': Irish Nationalism and the Policing of Revolutionary Terrorism in Bengal" in the Journal of British Studies, Vol. 39, No. 4. (October, 2000).

${ }^{15}$ Silvestri's thesis is supported by the Report on the Activities of Terrorists in Bengal, compiled by Special Superintendent R.E.A. Ray. Ray noted that Bengali revolutionaries had originally looked on random assassinations or bombings as the "limit of possible achievement." In the 1920s, however, such organizations as the New Violence party espoused an orchestrated program of simultaneous demonstrations, as well as "jail outbreaks, the destruction of bridges, the wrecking of trains, and the murder of spies and informers." (602-603)

${ }^{16}$ The conference featured papers on Indian and Irish literary figures, as well as research on papers addressing issues of famine, land, legislation, use of force, and the native press, many of which were assembled in Ireland and India: Colonies, Culture, and Empire, Tadgh Foley and Maureen O'Connor, eds. (Irish Academic Press, Ltd., 2006). Among those presenting at the conference whose work is citied in this dissertation are the aforementioned Michael Holmes and Michael Silvestri, as well as M.L. Brillman and
} 
With the exception of Richard Davis, there is a noticeable dearth of discussion concerning the Irish and Indian press. Scholars have chronicled the rise of the British press, examining the increase in literacy rates, advances in technology, and the oversized personalities who pioneered the industry. ${ }^{18}$ There exists, however, only a slim catalogue on Irish newspapers or the history of Indian journalism. ${ }^{19}$ Given the often fractious relationship between Britain and Ireland, the Irish press provides ample evidence of

Jennifer M. Regan. Michael Holmes and Denis Holmes also assembled an eclectic collection of essays in Ireland and India: Connections, Comparisons, Contrasts that revealed political, social, economic, military, diplomatic, and literary analogies between the two countries. Holmes, Michael and Denis Holmes, Ireland and India: Connections, Comparisons, Contrasts. (Dublin: Folens, 1997).

${ }^{17}$ See Michael Silvestri, Ireland and India: Nationalism, Empire and Memory. (Palgrave Macmillan, 2009); Jennifer M. Regan, Cosmopolitan Nationalism in the Victorian Empire: Ireland, India and the Politics of Alfred Webb. (Palgrave MacMillan, August 2009); and Kate O'Malley, "Ireland, India and Empire: Indo-Irish radical connections, 1919-64 (Manchester: Manchester University Press, 2008).

${ }^{18}$ See particularly Mark Hampton, Visions of the Press in Britain, 1850-1950 (Urbana and Chicago: University of Illinois Press, 2004) and Simon Potter, News and the British World: The Emergence of an Imperial Press System, 1876-1922 (Oxford: Clarendon Press, 2003). Whereas Hampton concentrates on the evolution of the role of the press in Britain, Simon Potter tracks the political and technological growth of the complex system which linked Britain with its imperial outposts. Potter further examines the intersection of Empire with the press in Ireland, Scotland, and Wales in Newspapers and Empire in Ireland and Britain: Reporting the British Empire, c. 1857-1921 (Dublin: Four Courts Press, 2004). In Media and the Empire, Chandrika Kaul offers a compilation of essays that look not only at the role of the newspaper, but also examine the impact of broadcasting on the Empire. (Houndmills, Basingstoke, Hampshire: Palgrave Macmillan, 2006.) See also Julie Codell, Imperial Co-Histories: National Identities and the British and Colonial Press (Madison: Fairleigh Dickinson University, 2003) and Keith Jeffery, ed., An Irish Empire? Aspects of Ireland and the British Empire, (Manchester: Manchester University Press, 1996), 77-93.

${ }^{19}$ For studies on the Irish press, see Stephen J. Brown, The Press in Ireland: A Survey and a Guide (Dublin: Browne and Nolan Limited, 1937); R.L. Munter, A Handlist of Irish Newspapers 1685-1750 (London: Bowes \& Bowes, 1960); Brian Inglis, The Freedom of the Press in Ireland, 1784-1841 (London: Faber and Faber Ltd., 1954); Hugh Oram, The Newspaper Book: A History of Newspapers in Ireland, 1649-1983 (Dublin: MO Books, 1983). Virginia Glandon, Arthur Griffith and the Advanced-Nationalist Press Ireland, 1900-1922 (New York: Peter Lang, 1985). John S. North. The Waterloo Directory of Irish Newspapers and Periodicals, 1800-1900 Phase II (Waterloo: North Waterloo Academic Press, 1986); and Marie-Louise Legg, Newspapers and Nationalism: The Irish Provincial Press, 1850-1892 (Dublin: Four Courts Press, 1999). For works focusing on the Indian press, see Margarita Barns, The Indian Press: A History of the Growth of Public Opinion in India (London: George Allen \& Unwin, Ltd., 1940); Professor Harida Mukherjee and Professor Uma Mukherjee, Bande Mataram and Indian Nationalism (1906-1908) (Calcutta: Firma K.L. Mukhopadhyay, 1957). Barns' work remains the most comprehensive overview to date of the evolution of Indian journalism, from the first printing press in 1674 and the publication of the first British newspaper through the tendentious relationship between the Government and the vernacular press. 
ambivalent attitudes toward the imperial mission, as seen in the recent work of Jill C.

Bender, Jennifer M. Regan, and Michael de Nie. ${ }^{20}$ Few scholars, however, have stepped forward to provide the necessary in-depth analysis of the Indian press that would offer new insights into Indian attitudes toward the British Empire. ${ }^{21}$ More importantly, what becomes apparent after a review of the existing literature is that scholars have made no attempt to compare the native press in India with the press in Ireland.

The dissertation thus provides the first comparative analysis of the Indian and Irish nationalist press. $^{22}$ It situates the leading nationalist papers within a global context, examining their simultaneous coverage of Europe's imperial wars to establish common philosophies, methods, and goals. My study fills a noticeable gap in speaking to shared nationalist aspirations, documenting how Irish and Indian editors readily acknowledged in print their mutual admiration for each other's political and social strategies. The dissertation argues that the leading editors of the Indian, Irish, and Irish-American press not only promoted a nationalist agenda within their own countries, but also worked in concert to construct a global anti-Imperialist platform. By highlighting the anti-imperial

\footnotetext{
${ }^{20}$ Jill C. Bender, "Mutiny or Freedom Fight? The 1857 Indian Mutiny and the Irish Press," in Potter, Reporting the British Empire, 92-108, as well as Jennifer M. Regan, "We Could Be of Service to Other Suffering People," in Victorian Periodicals Review (Volume 41, Number 1, Spring 2008,), 61-77; Michael de Nie, "'Speed the Mahdi!' The Irish Press and Empire during the Sudan Conflict of 1883-1885," in Journal of British Studies, (Vol. 51, No. 4, October 2012), 883-909. See also Donal P. McCracken, The Forgotten Protest: Ireland and the Anglo-Boer War. (Belfast: Ulster Historical Foundation, 2003. First published Johannesbuurg and Capetown: Perskor Publishers, 1989); Donal Lowry, "Nationalist and Unionist Responses to the British Empire in the Age of the South African War," in Potter, Reporting the British Empire, 159-176.

${ }^{21}$ Davis' analysis of Indian coverage of the 1916 Easter Rising in Ireland and David Omissi's pointed discussion of race in the coverage of the South African War provide notable exceptions. Richard Davis, "The Influence of the Irish Revolution in Indian Nationalism: The Evidence of the Indian Press 1916-22." South Asia, Vol. 9, No. 2 (1986), 55-68 and David Omissi's "Some Perceptions of Race and Empire," in The Impact of the South African War (Houndsmills, Basingtoke, Hampshire: Palgrave, 2002.)

${ }^{22}$ The dissertation has its origins in a thesis written in fulfillment of a 2005 Master of Arts degree at Florida Atlantic University. That study was also comparative in nature, analyzing the impact of Bal Gangadhar Tilak and Arthur Griffith on the construction of a nationalist platform in India and Ireland.
} 
rhetoric of the nationalist press in Ireland and India and illuminating their mutual strategies for attaining self-government, the study demonstrates the power of the media to alter imperial dynamics and effect political change.

The project provides tangible evidence that Irish and Indian attitudes toward the British Empire and its imperial wars were often at odds-identifying striking dissimilarities, not only in terms of linguistic form and style, but also in matters of race and religion. It argues that racial and religious prejudice frequently determined the Irish and Indian journalists' attitudes toward combatants in the imperial wars. Prevailing racial theory was clearly a deciding factor in how white Irish editors elected to portray the "yellow" Chinese Boxers and Japanese; the "dirty" Jews, and, more pointedly, the Indians themselves, whereas pan-Asian sentiment spurred Indian sympathy for the Boxers and the Japanese. The dissertation highlights growing Indian resentment toward the Christian nations of the West and underscores Irish ambivalence—and even animosity—toward non-Christian combatants.

The dissertation, moreover, is the first to offer a comparative focus on Irish and Indian press coverage of the imperial wars fought between the years of 1899-1914—a tumultuous period that included the Boxer Rebellion (1899-1901), the Second Boer War (1899-1902), the Russo-Japanese War (1904-1905), and the opening salvos of the First World War. The conflicts of this era thus become the prism through which the methods and motives of nationalist journalists in Ireland and India are explored and analyzed. Whereas other historians have focused on a single conflict during this era, they have overlooked the value of comparative analysis. The study, therefore, provides the first collective examination of Irish and Indian war coverage, revealing the subtle changes in 
rhetoric, shifts in attitude toward the Empire, and the emergence of a concrete nationalist platform.

The historian wishing to analyze the vast output of the native press in India faces not only the scarcity of surviving newspapers, but, more particularly, the challenge of its myriad dialects and languages. Thus, current scholarship focuses primarily not on the newspapers themselves, but on excerpts compiled weekly for the Government of India in the Presidencies of Bombay, Bengal, Madras, Punjab and the Northwest Territories. These Reports on the Native Newspapers encompassed native writings on topics ranging from domestic concerns such as agriculture, religion, plague, and famine, to foreign affairs and the Empire. Whereas these excerpts are a boon to the historian, their use is not without a measure of controversy. Not only is there the question of whether the translations were accurate, but also the fact that the choice of which papers and which excerpts were included in the compilation was solely at the discretion of the translator. Unless specifically stated by the translator, moreover, there is no way of ascertaining who authored a specific excerpt, or even whether an editor or a staff member penned the article. The mitigating factor with all these caveats is that the translator's focus on certain topics provides an indication that native opinion on those issues was a concern to the Government of India, just as the choice of newspapers selected is proof that their influence was acknowledged by officials.

These dual realities are borne out in the Annual Report on the Native Newspapers, which provided analysis on the issues of most concern to natives, identified the most obstreperous of the newspapers, and addressed the tone of the press, itself. Officials quickly noted that the Presidencies of Bombay and Bengal featured the newspapers most 
antagonistic to the Empire. Thus, newspapers from both Presidencies figure prominently in the dissertation. The Reports on the Native Newspapers from the Bombay Presidency are no longer available, however, for the years 1899-1900. Thus, they will make their first impact in Chapter Three, with coverage of the second half of the Boer War.

Chapter One explores the reasons for the rapid growth of the Irish and Indian nationalist press within the British Empire at the end of the nineteenth century, and examines its ability not only to educate and influence, but also to serve as a representative of the people. With literacy rates rising, the price of newspapers dropping, and no shortage of sensational news to report, Indian and Irish nationalist editors discovered they were able to construct a political platform and build support for their agendas by taking their causes directly to the masses. The chapter also tracks the emergence of the editors who became the key agents of change in Ireland and India, and charts the legislation designed by the British Government to muzzle the increasingly discordant voices of discontent within Ireland and the subcontinent.

Chapter Two analyzes coverage of the Boer War from the opening hostilities in 1899 through the capture of Pretoria in the summer of 1900, providing compelling evidence that the crisis in the Transvaal was the catalyst for a renewed and impassioned embrace of the nationalist agenda in Ireland and India. Irish advanced-nationalist journalists simultaneously blasted British aggression, praised the courage of the Boerswhite, Christian, and victims of imperial expansion — and indelibly linked their quest for independence to that of the Irish. Whereas Indian nationalist editors still maintained their allegiance to the Empire, cracks in the veneer of that loyalty were beginning to appear, 
prompted by Britain's neglect of affairs on the subcontinent and, in particular, its racially-motivated refusal to deploy Indian troops to the Transvaal.

Chapter Three examines the coverage by the Indian nationalist press and Irish advanced-nationalist press of the Boxer Rebellion, revealing differences in their approaches to events in China. Having openly expressed animosity toward the British Empire, Arthur Griffith and his colleagues sought to ascribe self-serving motives to Britain's conduct in the conflict. Yet, given that Britain was only one of eight European nations involved in subduing the revolt, the Irish advanced-nationalist press could launch only a limited attack, characterizing the British as callous aggressors trampling the Chinese rebels in furtherance of a relentless expansionist policy. By contrast, the Indian nationalist press was clearly ambivalent about the Rebellion — wishing to remain loyal to the Empire, but profoundly troubled by what it perceived as an imperial policy debased by racial and religious prejudice.

Chapter Four returns to South Africa to chronicle the renewal of hostilities in the Boer War, followed by Britain's resort to a scorched earth policy in order to subdue the Boers. Coverage of these new developments marks the beginning of Irish and Indian nationalist editors marching in lockstep, as journalists in both countries roundly denounced the burning of farms and the internment of women and children. More than any other imperial war to that date, the Boer War offered tangible evidence of the Empire's fallibility—not only enabling nationalist editors in Ireland and India to launch a combined attack on British honor, but also giving their impassioned call for selfgovernment both weight and urgency. 
Chapter Five addresses the years between the close of the Boer War and the onset of the First World War, analyzing coverage of the Russo-Japanese War, the Partition of Bengal, and the birth of the self-reliance movements, Sinn Féin and Swadeshi. ${ }^{23}$

Whereas none of these events involved British troops in battle, each proved a significant boon to the nationalist cause. While Indian nationalist editors trumpeted the victory of an Asian power over the West, Irish advanced-nationalist editors treated the Partition of Bengal as if it was, indeed, another British imperial war designed to subjugate an oppressed Indian people. Significantly, the contemporaneous movements of Sinn Féin and Swadeshi fed voraciously off each other, as editors in India and Ireland persistently reminded their readers of the common bond between Ireland and the subcontinent.

The Epilogue returns, once more, to the coverage of an imperial conflict in which participation by the British Empire is integral, with news of the First World War making its initial appearance in the pages of the Indian and Irish nationalist press. The Epilogue analyzes the complex tangle of issues and emotions that determined how journalists in Ireland and India would report World War I, and where their loyalties resided at the onset of the war. Finally, it looks forward to developments during the course of the next four years to establish the status of the Irish and Indian nationalist press at the close of the Great War.

A side by side examination of contemporaneous Irish and Indian press coverage yields valuable information not only about the parallel tracks of nationalist aspirations, but also about the tensions within the Empire. The simultaneous growth of the nationalist press in India and Ireland, the similarity of editorial content, the reciprocity of ideas, the

${ }^{23}$ Sinn Féin is Irish for "ourselves alone," while Swadeshi is a Hindi word meaning "self-sufficiency" or "of our own country." 
mutual embrace of each other's struggles, and the uncanny correlation between legislative efforts aimed at suppression of the papers make further investigation of this complex relationship imperative. 


\section{"An Insurrection in Print": The Press and The Empire}

By the summer of 1897, Her Majesty Queen Victoria had reigned over the United Kingdom for an unprecedented sixty years. Accordingly, in honor of her glorious Diamond Jubilee, the British Government declared a public holiday "at all public places where British subjects were resident"-including India, the imperial jewel in the crown of the monarch. ${ }^{24}$ That the subcontinent was reeling from a devastating plague seemed lost on authorities planning the festivities, although even a cursory reading of the native press would have alerted them to the tension and unrest in the Bombay Presidency. "To speak the truth," chided the Kesari, Bombay's most influential native paper, "none can help thinking that this is surely not the proper time for celebrating the Jubilee, at least not in India." 25 More pointedly, the editor questioned the rationale for celebrating Victoria's Jubilee at all, asserting that the occasion marked "the sixtieth anniversary not of our prosperity, but of our decline."26

On the evening of 22 June 1897, as the joyous celebrations in Poona were coming to a close, shots rang out — transforming the festive evening into a night as historically momentous for the Empire as it was gruesome for those on the spot. Lieutenant C.E. Ayerst died instantly from his injuries, while the primary target of the bullets, W.C. Rand, Plague Commissioner for the Bombay Presidency, would linger eleven days before succumbing to his wounds. Within days, authorities arrested brothers Damodar and

\footnotetext{
${ }^{24}$ The British Monarchy, Internet; available at http://www.royal.gov.uk/HMTheQueen/ TheQueenandspecialanniversaries/Factfiles/QueenVictoriasDiamondJubilee.aspx; accessed on 27 January 2013.

${ }^{25}$ Kesari, 22 June 1897.

${ }^{26}$ Cited in Wolpert, 87.
} 
Balkrishna Chapekar. For their crimes, the assassins were charged with murder, tried, and hanged. Officials, however, did not believe the brothers had acted alone, or without provocation. Accordingly, under the terms of Section 124A of the Penal Code, Lord Hamilton, the Secretary of State for India, leveled charges of sedition against Bal Gangadhar Tilak, editor of the Kesari. ${ }^{27}$

While at first glance Tilak's arrest seems a case of imperial overreach, the move was not without precedent in the British Empire. Not only had the Government of India previously charged Indian editors with inciting discontent, but also Dublin Castle had arrested and imprisoned United Irishman editor John Mitchel in 1848 and tried and imprisoned United Ireland editor William O'Brien in 1887, among others. ${ }^{28}$ There was a long-standing concern that Irish and Indian newspapers fomented discontent and disaffection among the masses, whom officials characterized as far too impressionable to be able to withstand the heated rhetoric emanating from the pages of the nationalist press.

In the case of Tilak and the Kesari, the editor's disdain for the Government's plague regulations was no secret, as the editor had been publicly lambasting Rand and his intrusive procedures for months. ${ }^{29}$ In an effort to curtail the spread of the terrifying

\footnotetext{
${ }^{27}$ In an autobiography written in his cell, the real assassin, Damodar Chapekar, demonstrated the impact of Tilak's column when he wrote "viewed in a proper light this was not a time for rejoicing. There was plague in the Bombay presidency, earthquakes on the Calcutta side, and a terrible famine all over India." Cited in Stanley A. Wolpert, Tilak and Gokhale: Revolution and Reform in the Making of Modern India (Berkeley: University of California Press, 1977), 88.

${ }^{28}$ The arrests of United Irishman editor John Mitchel and United Ireland editor William O'Brien are discussed later in this chapter.

${ }^{29}$ For an analysis of the Government's handling of the plague crisis, the assassination of Rand, and Tilak's trial, see Wolpert; Myron J. Echenberg, Plague Ports: The Global Urban Impact of Bubonic Plague, 18941901 (New York and London: NYU Press, 2007); and Mohammad Shabbir Khan, Tilak And Gokhale: A Comparative Study Of Their Socio-Politico-Economic Programmes Of Reconstruction (Ashish Publishing House, 1992).
} 
disease, authorities had mandated searches of private dwellings - incursions that offended the Hindu and Muslim populations, alike, and created deep feelings of resentment throughout India. Giving voice to that shared sense of outrage, Tilak proclaimed, "My heart is full of indignation at the injustice which is being perpetrated by the officials and the words which come out are the natural outburst of the feelings inside me." ${ }^{\prime 30}$ Convinced his criticism was protected by law, the editor reserved his most damning accusation for Rand, declaring "the Bombay Government should not have entrusted the execution of this order to a suspicious, sullen and tyrannical officer like Rand."”1

Authorities grew even more animated at Tilak's assertion that "No blame attaches to any person if he is doing his deeds without being actuated by a desire to reap the fruit of his deeds"- - seeming, as it did, to exonerate in advance the sibling assassins. ${ }^{32}$ If proof was needed that British authorities feared the profound influence the native press exerted over its readers, it lay in the Government's proceedings against Tilak in the aftermath of the Rand assassination. ${ }^{33}$ Regardless of whether the public actually concurred with Tilak, or whether they had even read his editorials, Tilak's trial and

\footnotetext{
${ }^{30}$ Cited in D.V. Tahmankar, Lokamanya Tilak: Father of Unrest and Maker of Modern India (London: John Murray, 1956), 78.

${ }^{31}$ Kesari, May 1897, cited in Echenberg, 66.

${ }^{32}$ Kesari, 15 June 1897, Cited in Richard I. Cashman, The Myth of the Lokamanya: Tilak and Mass Politics in Maharashtra. (Berkeley: University of California Press, 1975), 114. Years later, Tilak would return to the subject of the assassination, renewing his belief that the Chapekar brothers were, in fact, righteously motivated. "These murders have assumed a different aspect from ordinary murders," asserted the editor, "owing to the supposition (on the part of the perpetrators) that they were doing a sort of beneficent act." Cited in Mohammad Shabbir Khan, Tilak and Gokhale: A Comparative Study of Their Socio-PoliticoEconomic Programmes of Reconstruction (Ashish Publishing House, 1992), 104.

${ }^{33}$ Hearing of the tragedy, the New York Times sounded an alarm, informing its readers about the "Outburst of Anti-British feeling in the native press of Bengal and Bombay." The paper warned of a possible repeat of the 1857 rebellion, and suggested that the British Empire might, once again, impose strict censorship on the more intemperate journalists of India. “The Trouble in India," New York Times, 3 July 1897.
} 
subsequent imprisonment make clear that officials had convinced themselves that his words were setting a dangerous precedent. Already dealing with the incendiary writings of an Irish nationalist press that excoriated British policy on a daily basis and seemed hell-bent on severing ties with the Empire, the British Government now found itself confronting increasingly obstreperous voices in the Indian nationalist press. The repressive measures adopted by the British Government against journalists in both Ireland and the subcontinent provide compelling evidence that officials believed the nationalist press capable not only of disrupting and obstructing official business, but also of endangering the Empire.

\section{The Role of the Press}

It was the nationalist press that framed the debate about the British Empire, constantly analyzing and evaluating imperial policy, and reminding readers that their plight was shared by other imperial subjects. The Irish Parliamentary Party, founded in 1882 under the aegis of Charles Stewart Parnell, had attempted to draw attention to Ireland's agrarian plight, while the Indian National Congress, formed in 1885, sought to give voice to the problems of the subcontinent. Largely composed of members of an educated middle class steeped in British tradition, both bodies toiled in concert with the

British Government — believing that working constitutionally within the system was the most efficient and democratic way to move their countries forward. Their failure to effect change rapidly and demonstrably, however, led to frustration among their supporters, compounded by an inability to reach the masses. Thus, in Ireland and India, it was the press that labored to further the cause of nationalism. 
Benedict Anderson asserts that one of the reasons a nation remains only an imagined community is because members "will never know most of their fellowmembers, meet them, or even hear of them. ${ }^{\prime 34}$ Absent that face-to-face interaction, the possibility of discovering commonality is remote. The nationalist press in India and Ireland provided an antidote to this anonymity, forging a link based on common concerns and anxieties, aspirations and desires. The "one-day best seller" that was the Irish or Indian nationalist newspaper linked readers as they engaged in simultaneous consumption of the latest anti-imperial rhetoric. ${ }^{35}$ In the process, the press helped give substance to an illusion, a feeling of permanence to what had only been ephemeral, and strengthened the bonds of the "horizontal comradeship," to use Anderson's term, that was slowly being forged. ${ }^{36}$

A close reading of period newspapers reveals not only the major issues of the day and the positions staked out by each party, but also the role of the press in setting the parameters of the public debate. The late Eric Hobsbawm suggested that one of the outcomes of the burgeoning world economy in the Age of Empire was the birth of mass media, "which, for the first time, deserved the name." ${ }^{37}$ Hobsbawm observed that the last decade of the nineteenth century witnessed a marked increase in the circulation of newspapers, with a British newspaper, Lloyds Weekly, achieving a million-copy sale for the first time. Instinctively grasping the power of the press to reach this vast audience, the British Government and its ardent proponents, such as publishing magnate Lord

\footnotetext{
${ }^{34}$ Benedict Anderson, Imagined Communities (London and New York: Verso, 1983), 6.

${ }^{35}$ Ibid, 35

${ }^{36}$ Ibid, 7.

${ }^{37}$ Eric Hobsbawm, The Age of Empire, 1875-1914 (London: Abacus, 1994), 53.
} 
Northcliffe, seized on the press as a means of communicating, forwarding, and defending the imperial agenda. ${ }^{38}$ Indeed, Niall Ferguson claims that "it was above all through the popular press that the Empire reached a mass audience at home," while Michael de Nie asserts that this platform granted the press "considerable, perhaps unparalleled, authority in shaping popular understandings of the empire and its peoples." ${ }^{39}$ Whether an Englishman in London believed the British Empire was engaged in a glorious civilizing mission or a grasping territorial expansion depended largely on which paper he read that morning.

The axiom was particularly true in time of war, when the newspaper was perhaps the only source of information regarding events occurring in South Africa, China, Russia, or Japan. ${ }^{40}$ Whereas the British press was particularly effective in convincing the public of the justice of the imperial cause, the Irish and Indian nationalist press learned to counter the official version of events. These years chronologically belong not only to the Age of Imperialism (1850-1914), but also to the Age of Nationalism. The availability of newspapers as a conduit to convince the masses of the righteousness of a cause, therefore, was not lost on those in Ireland and India who opposed the policies of the British Government. They adopted the persuasive techniques of the British press, but

\footnotetext{
${ }^{38}$ Northcliffe was the owner of the Evening News, the Daily Mail, the Daily News, the Sunday Observer, and ultimately, the Times.

${ }^{39}$ Niall Ferguson, Empire: How Britain Made the Modern World (London: Penguin Books, 2004), 257; de Nie, "'Speed the Mahdi!'," 888.

${ }^{40}$ Ferguson notes that the Empire could be promoted both from the right, by such figures as Northcliffe, and from the left, by such publishers as William Thomas Stead, who famously described himself as "an imperialist plus the ten commandments and common sense." (258) Stead was the owner of the Pall Mall Gazette and the founder of the Review of Reviews At a time when many editors loyally reprinted the official version of events, Stead refused to blindly toe the imperial line, and leavened his commentary with compassion and reason.
} 
ingeniously honed and refined them, speaking a language specifically designed for their readers. Historian Jerry W. Knudson argues that what people believed was happening"as revealed to them through the means of mass communication"-is equally important to the historian as what may have actually transpired. ${ }^{41}$ "Thus," Knudson concludes, "the perception of events as filtered through the press may have changed the historical outcome. ${ }^{42}$ If the press possessed the power to portray the Empire as a magnificent realm on which the sun would never set, it also had the capacity to paint a portrait of the Empire as a devastated landscape on which the blood would never dry.

In attempting to discover how the press emerged as a formidable social and political entity, scholarship has been driven by both quantitative and qualitative data. In addition to charting the growth of the press and undertaking a critical assessment of its impact, it is vital to examine the mission of the press, and to identify those editors who functioned as the primary agents in forwarding a nationalist agenda. Analyzed in concert, these factors provide valuable evidence of the power of the Irish and Indian nationalist press during wartime to direct the conversation, mount resistance to the Empire, and construct a national platform.

\section{The Growth of the Press}

Scholars agree that for the British press to have grown and prospered in the latter half of the nineteenth century required the simultaneous presence of several felicitous

\footnotetext{
${ }^{41}$ Jerry W. Knudson, "Late to the Feast: Newspapers as Historical Sources," in American Historical Association Perspectives (October 1993); Internet; Available at http://www.historians.org/perspectives /issues/1993/9310/9310ARC.cfm; accessed on 13 March 2013.

${ }^{42}$ Ibid.
} 
circumstances: a rising level of literacy; advances in technology that made it possible to produce newspapers at an affordable price; a driving issue that could seize the attention of the public; and a pantheon of visionary editors who understood how to exploit the power of the press. Many of the same factors that helped the British press rise to prominence also ensured that the Irish and Indian press would take the lead in promoting national discussion. Hugh Oram was among the first to examine the impact of higher literacy rates on the popularity of the Irish press, noting that whereas once only the Protestant gentry and middle class had access to newspapers, legislation directed at improving education had the desired effect of increasing literacy among the lower classes. $^{43}$

Literacy in Ireland generally meant proficiency in English, as British legislation in the 1830s mandated that English would be the language of education in all Ireland's national schools. For centuries, the British Government had viewed the speaking of Irish with suspicion, characterizing as disloyal those who persisted in speaking their native tongue. ${ }^{44}$ In Ireland, by the advent of the nationalist movement, English was the predominant language, with the Irish-speaking public primarily confined to the gaeltachts - small enclaves in the west and northwest. Until Arthur Griffith and his fellow editors made a concerted effort to include the Irish language in their papers at the

\footnotetext{
${ }^{43}$ Hugh Oram, The Newspaper Book: A History of Newspapers in Ireland, 1649-1983 (Dublin: MO Books, 1983). Kenneth O. Morgan is among the more recent historians to examine this same phenomenon, discussing the impact of the 1870 Forster Education Act on the reading public in Britain. Morgan credits the new bill with creating a literate public eager to consume the news from the imperial wars at the turn of the century. See "The Boer War and the Media," in Twentieth Century British History, (Vol. 13, No.1, 2002), 1-16.

${ }^{44}$ Sean Cahill (Seán Ó Cathail), "The Politics of the Irish Language under the English and British Governments, "in The Proceedings of the Barra Ó Donnabháin Symposium, 115; Internet; available at http://irelandhouse.fas.nyu.edu/docs/CP/4172/0111-0126_PoliticsOfTheIrishLanguage.pdf; accessed on 22 March 2013.
} 
turn of the twentieth century, newspapers in Ireland were published almost exclusively in English. Protestant ownership of the Irish press, however, had given way to a spate of publications backed by the Catholic Church. ${ }^{45}$ The result was a proliferation of nationalist-leaning newspapers in the Irish provinces and a subsequent increase in circulation figures. The cost of newspapers in Ireland had also decreased appreciably, making their purchase accessible to a large constituency. ${ }^{46}$

Conversely, in India, language initially constituted a significant barrier to education, literacy, and the consumption of papers. On the subcontinent, although English had been taught in schools since the passage of the Charter Act of 1813, India was a country in which fifteen languages and more than sixteen hundred dialects were regularly spoken. Thomas Babington Macaulay's rather infamous 1835 “Minute on Indian Education" had made it clear that Britain's efforts to educate should make use only of English and not of the vernaculars, and that such teaching should be confined to "a class of persons, Indian in blood and colour, but English in taste, in opinions, in

\footnotetext{
${ }^{45}$ Among the provincial papers that came into being during these crucial years were the Leinster Leader (1880), Midland Tribune (1881), Tipperary Nationalist (1881), Westmeath Examiner (1882), Carlow Nationalist (1883), and Western People (1883). Oram, 77.

${ }^{46}$ Padraic Colum, Arthur Griffith, (Dublin: Browne and Nolan Limited, 1959), 46. In 1899, the premiere issue of Arthur Griffith's United Irishman sold for a half-penny. Griffith and his fellow owner William Rooney went to extraordinary lengths to maintain the low cost of the paper to the public, choosing to write every word of the initial issues of the journal, themselves, and relegating to Griffith the job of setting all of the type. As remuneration for the extra task, Griffith paid himself twenty-five shillings per week. To disguise the fact that all of the articles had been written by only two journalists, the pair hid behind a variety of pseudonyms, many of which Griffith would continue to use throughout his tenure as editor of the United Irishman and its successor, Sinn Féin. Among the monikers used by Griffith were Calma, Cugan, Cloakey, Go One, Hop, Ier, Jap, Joseph Smith, Lugh, Mafosta, Mise, Nationalist, Old Fogey, Rathcoole, Rover, and Shanganagh. Source: Glandon, 67, FN 30.
} 
morals, and in intellect." 47 Therefore, India's English-language papers appealed primarily to an audience of elites.

On the subcontinent, the Anglo-Indian press flourished particularly in the Bombay and Bengal Presidencies, and remained demonstrably loyal to the British Empire even through the rise of Indian nationalism and the most tempestuous of events. The native-owned press, by contrast, functioned far more autonomously, attempting to evaluate issues not merely on the basis of whether a given outcome benefited the Empire, but also from the perspective of the community, the religious sect represented by the paper, and India, at large. There was, moreover, a critical difference between those moderate nationalist newspapers that hewed closely to the platform of the Indian National Congress and those more radical publications, such as Bal Gangadhar Tilak's Kesari and Shivram Mahadev Paranjape's Kál that pursued a more extremist agenda. There was, therefore, rarely a monolithic native press response to issues of the day.

What enabled the Indian nationalist press to emerge ultimately as a force to be reckoned with was the advent of vernacular newspapers, which provided an enormous boon to readership, as news could finally be communicated in Bengali (Samachar Darpan, 1816), Gujarati (Bombay Samachar, 1822), Marathi (Darpan, 1832), and Tamil (Swadesamitran, 1882), among an impressive range of other languages. By 1885, there were three hundred nineteen vernacular publications in print, far outnumbering the

\footnotetext{
${ }^{47}$ Thomas Babington Macaulay, "Minute on Indian Education,” Modern History Sourcebook. Internet; available at http://www.fordham.edu/halsall/mod/1833macaulay-india.asp; accessed on January 17, 2013. 1884 saw the establishment of universities in the key cities of Bombay, Calcutta, and Madras. The benefits of an British education, however, were not extended to Indian girls until 1882.
} 
ninety-six English-language journals. ${ }^{48}$ With the literacy rate in India hovering at only six per cent at the turn of the century, moreover, the practice of communal reading proliferated. $^{49}$ One educated Indian reading aloud to an assembled audience in a small village ensured the timely communication of topical news. ${ }^{50}$ The Government of India would come to view the vernacular press with suspicion and even fear, as the content of the papers could be shared across the community before hired translators managed to present their superiors with an English translation.

If literacy and the easy availability of newspapers were integral elements in the growth of the press, the emergence of substantive and controversial issues around which the press could coalesce would prove the decisive factor. In India, the vernacular press drew its strength from a series of social and political fracases that attracted the attention of a specific spectrum of the population. Among them, the debate over the practice of suttee led to a rise in Bengali papers, while a heated discussion within the Parsi population in Bombay over the calendar sparked an increase in Gujarati papers. ${ }^{51}$ More generally, the grim reality of Indian agrarian strife, compounded by devastating plague and famine - catastrophes common to all —-helped to increase sales and circulation in the

\footnotetext{
${ }^{48}$ Lawrence James, Raj: The Making and Unmaking of British India (New York: St. Martin's Griffin, 1997), 356.

${ }^{49}$ Cited in Department of School Education; Internet; available at http://www.tn.gov.in/schooleducation/ statistics/table4-lit.htm; accessed on 28 March 2013.

${ }^{50}$ Mark Hampton notes that communal reading was also a common tradition in Britain. He suggests that the practice of reading the paper aloud "may have helped to ease the transition from an oral popular political tradition to a literate working-class public." Mark Hampton, Visions of the Press in Britain, 1850-1950 (Urbana and Chicago: University of Illinois Press, 2004), 27.

${ }^{51}$ Barns, 189 .
} 
last decade of the nineteenth century. ${ }^{52}$ As was the case on the subcontinent, the years which featured the birth of a spate of nationalist papers in Ireland coincided with the period of the Irish Land War. ${ }^{53}$ Provincial papers latched onto the issue of land agitation and criticized Britain's mishandling of the crisis, in the process, transforming the Land War into a national topic capable of firing the passions of its readership. ${ }^{54}$ The advent of any imperial war — whether in Afghanistan, the Sudan, South Africa, or Chinaprompted a dramatic increase in readership across the Empire. ${ }^{55}$ For the Irish and Indian nationalist press, coverage of war offered the prospect of a sizable readership and an unrivaled opportunity to espouse their views.

\footnotetext{
${ }^{52}$ Drought and the subsequent failure of crops was a fixture of daily life in India—only one of many crises of nature India confronted in the waning decades of the nineteenth century. In 1896, an epidemic of bubonic plague erupted in Bombay, which devastated the population, ultimately leading to over twelve million deaths across the subcontinent. British measures to control the outbreak were considered not only insensitive, but also intrusive, and alienated much of the populace. India also suffered three catastrophic famines, including the Great Famine of 1876-1878, which resulted in 5.5 million deaths in British territory; the famine of 1896-1897, which took the lives of another five million; and the famine of 1899-1900, which brought about the deaths of another one million Indians.

${ }^{53}$ The Irish National Land League, founded by Michael Davitt in 1879, set in motion the Irish Land War, in an attempt to support struggling tenant farmers. The Land League initially focused on obtaining the three F's: Fair rent (rent control); Fixity of Tenure (forbidding landlords from evicting tenants who had paid their rent); and Free Sale (allowing the tenant to sell his land). The Land War also was the setting for the implementation of Charles Stewart Parnell's boycott strategy, as well as the Plan of Campaign launched by William O’Brien, John Dillon, Timothy Healy, and Timothy Harrington.

${ }^{54}$ Legg, 173. Marie-Louise Legg suggests that although the provincial press benefited from the 1852 abolition of taxes on newspapers, it truly came into its own when it latched onto the issue of agrarian strife and the desperate plight of tenant farmers who were summarily evicted from their land. Characterizing land as "the motor of the nationalist machine," Legg credits the provincial press with identifying the very tenets of Irish nationalism, including economic self-reliance, respect for the Irish language and cultural heritage, and independent political control over Ireland. Notably, these same elements would feature prominently in Arthur Griffith's Sinn Féin policy, as well as the Indian policy of Swadeshi, promoted by the Indian native press.

${ }^{55}$ Ferguson points out that the Boer War sent sales of the Daily Mail soaring over the one million mark.
} 


\section{The Mission}

Given the existence of such a popular platform, the question of how the press chose to define its role assumed great magnitude. Simon Potter notes that historians have tended to stress the cooperation of the press "in the broader attempt of the British media to educate and edify the public," claiming that there was a concerted effort "to give the people what they should have rather than what they necessarily want." Tilak specifically fixed on the vernacular newspaper to educate the peasant population of India, arming them with the information necessary to stake a claim to the running of their own country. Whereas this sense of public mission did, indeed, mark the formative years of the press in Britain, Mark Hampton discerns a transition of the British press from its initial dedication to an educational ideal — designed to influence and inform - to a representative ideal, by which the people could speak truth to power. Whereas Hampton asserts that the first tradition dominated the thinking of journalists from the 1850 s to the 1880 s, the latter representative ideal rose to prominence in the last two decades of the nineteenth century. "In this view," states Hampton, "the press did not influence readers or public opinion but reflected them.",57

The relationship between the Empire and its subjects was constantly in flux, buffeted by such unpredictable occurrences as drought, famine, and disease, and.by manmade issues that included social inequality, economic uncertainty, and, especially, imperial wars. The press was not only the channel through which the Government could

\footnotetext{
${ }^{56}$ Simon Potter, The Emergence of an Imperial Press System, 1876-1922 (Oxford: Clarendon Press, 2003), 12.

${ }^{57}$ Mark Hampton, Visions of the Press in Britain, 1850-1950 (Urbana and Chicago: University of Illinois Press, 2004), 9.
} 
communicate its policies and the people could make their will known; it was also the means of persuading its anonymous readers to challenge those policies. "The newspaper press," asserts Michael de Nie, "was understood to be the main vehicle for a conversation among readers, journalists, and politicians in which the former two could most effectively register their views and influence, for good or ill, the decisions of the imperial state." 58 Thus, according to de Nie, the study of press commentary affords the historian the unique ability to "understand how imperial controversies unfolded in the public sphere." 59 As disturbing to British officials as Irish and Indian criticism of any war effort must have been, negative editorials and letters to the editor offered invaluable insights into the public's perception of that conflict.

As tempting as it is to make a clean delineation between the two primary functions of the press, the evidence reveals that the educational and representative ideals overlapped considerably in the Irish and Indian nationalist press. ${ }^{60}$ The Liberal characterization of the press as the fourth estate meant that it would not only reflect public opinion, but also simultaneously lead public opinion, in an effort "to control the political actions of the masses." ${ }^{\prime 61}$ Yet, as Potter points out, there was concern among

\footnotetext{
${ }^{58} \mathrm{De} \mathrm{Nie}, 885$.

${ }^{59} \mathrm{De} \mathrm{Nie}, 886$.

${ }^{60}$ Indeed, Brian Inglis argues that the Irish press was slow to give vent to its educational zeal, noting that Sir Robert Peel, the Chief Secretary for Ireland (1812-1818) hiked the price of publishing a newspaper to an exorbitant rate, in the hopes that only those papers subsidized by the British Government could stay afloat. Proclaiming his belief that "an honest despotic government would be by far the fittest government for Ireland," Peel did not hesitate to use the courts to clamp down on any Irish journalists who opposed the Government, leading to a press that Inglis has asserted "reflected, rather than influenced, trends." Brian Inglis, The Freedom of the Press in Ireland, 1784-1841 (London: Faber and Faber Ltd., 1954), 17; 134135.

${ }^{61}$ Potter, News and the British World, 39. Potter ascribes much of the criticism to Liberal journalist John A. Hobson, who penned the 1902 work Imperialism: A Study.
} 
many that the London Times and other British papers were perverting public opinion in the service of imperial jingoism. Indeed, Jennifer Regan questions whether the reason Irish nationalism so aggressively promoted in the pages of the Nation during the Indian Mutiny was, perhaps, Ireland's answer to the rampant jingoism present in the British press. ${ }^{62}$ The question must, therefore, be asked whether in the attempt to promote Irish nationalism, the Irish press was not, in fact, guilty of fashioning its own chauvinistic culture. Indeed, editors worked assiduously to frame the political debate churning around Britain's imperial mission in terms that directly related to the Empire's treatment of its Irish and Indian subjects.

\section{The Agents of Change}

That these critical decisions regarding a newspaper's mission lay in the hands of a mere handful of visionaries raises one of the more fascinating aspects of the Indian and Irish nationalist press. In Ireland and on the subcontinent, by the end of the nineteenth century, the same individuals who were in the vanguard of the nationalist movement were also the editors of, or leading contributors to, the most vocal and ardently nationalist newspapers. These highly political journalists not only toiled to report the events of the day, but were also in the enviable position of being able to create the news their papers so studiously covered. They set the tone and, often, the agenda for their colleagues, making their influence prodigious - a fact acknowledged by officials, who privately voiced concerns about the impact of these powerful men. The issues Irish and Indian editors chose to embrace were startlingly similar in many respects - particularly in their

\footnotetext{
${ }^{62}$ Regan, 67.
} 
persistent call for self-reliance and home industry. In time, they would look across the sea to each other for support and encouragement, holding up an example to their readers of another country breaking away from the imperialist parade to march to its own nationalist tune.

Among those in India who served in both political and journalistic capacities were Surendranath Banerjea (Bengalee), Shivram Mahadev Paranjape (Kál), and Bal Gangadhar Tilak (Kesari, Mahrátta). Banerjea was founder of the Indian National Association, two-time President of the Indian National Congress, and editor of the Bengali-language Bengalee. One of the premier nationalist journalists in the Bengal Presidency, renowned for its anti-government agitation, Banerjea was one of the most insistent voices speaking out against what he characterized as the Empire's racial discrimination. Arrested and charged with contempt of court in 1883 for remarks published in the Bengalee, Banerjea served two months in jail and emerged to national acclaim. A popular draw on the speaker circuit, Banerjea's personal appearances served the dual purpose of enabling him to bring his editorial message to a broad audience, while simultaneously bolstering sales of the Bengalee. Alluding to the Government of India's refusal to allow natives entry to the officer ranks, Banerjea cautioned, "Racial qualifications are not moral qualifications," adding. "This ostracism of a whole people ... cannot add to the strength and the stability or the greatness of the Empire." ${ }^{63}$ The editor's warning was especially prescient given the controversy that would erupt over the participation of the Indian sepoy in the wars in China and South Africa.

\footnotetext{
${ }^{63}$ Surendranath Banerjea, Address to the Eleventh Congress, Poona, 1895 in G.A. Natesan, Indian National Politics: Indian National Congress, (1898), 147.
} 
In the Bombay Presidency, Shivram Mahadev Paranjape's Kál held the distinction of being the most reviled of all extremist nationalist newspapers - at least from the perspective of the Government of India, which characterized Paranjape's writings as "impregnated with the venom of disaffection." ${ }^{64}$ The Kál's circulation was second only to the Kesari, both in terms of circulation and influence. The Government of India closely monitored Paranjape, fearing not only his nationalist bent, but also his affinity for supporting the agenda of anarchists, nihilists, and revolutionaries. ${ }^{65}$ The Kál was arguably the most pronounced anti-imperial publication on the subcontinent, earning it the label of "virulent and treasonable." ${ }^{.66}$ Warned by officials in 1899, the editor refused to moderate the tone of the paper, prompting authorities to consider prosecuting Paranjape for seditious writings in $1900,1904,1905$, and $1907 .{ }^{67}$ In reviewing the history of seditious activity in India, Justice Rowlatt's Sedition Committee of 1918 referred to Paranjape as one of the two most influential journalists in all of Poona. ${ }^{68}$ The other was Bal Gangadhar Tilak.

If there was one editor whose influence was felt beyond the Bombay Presidency and across the length and breadth of India, it was Bal Gangadhar Tilak. The eventual leader of the extremist wing of the Indian National Congress, Tilak was the founder and editor of the English-language Mahrátta and Marathi-language Kesari newspapers, both founded in January 1881. Tilak believed that his uneducated readers "must be given the

\footnotetext{
${ }^{64}$ Annual Report on the Native Press of the Bombay Presidency for the year 1904, $\mathrm{L} \backslash \mathrm{R} \backslash 5 \backslash 159$.

${ }^{65}$ Sedition Committee Report. (Calcutta: Superintendent Government Printing, India, 1918).

${ }^{66}$ Annual Report, 1904.

${ }^{67}$ Sedition Committee Report, 4.

${ }^{68}$ Ibid, 13.
} 
knowledge of such topics as concern their everyday life by writings on literary, social, political, moral and economic subjects." ${ }^{69}$ A soldier on the front lines of Indian nationalism, Tilak's preferred weapons ranged from the veiled metaphor and the pointed barb to the open uncompromising editorial attack. Gazing out over the political landscape, Tilak decried the British despotism that had transformed India's would-be activists into what he termed "an aggregate of disunited, dispirited, unenergetic, unambitious, indifferent, unprincipled, selfish, cowardly fellows." ${ }^{70}$ Incensed and insistent, Tilak reserved special disdain for what he considered the arrogant policies of the British Government on issues ranging from the army and agriculture to the plague and famine relief. Although the Kál, another Bombay-based Marathi paper, was undoubtedly more virulent than the Kesari in its anti-imperial commentary, Tilak's paper enjoyed more than double the Kál's circulation and was acknowledged as the "most influential of vernacular papers" in the Bombay Presidency. ${ }^{71}$

Both Paranjape and Tilak were Chitpavan Brahmins, the elite of Bombay. As such, their immediate audience was comprised of the educated, literate members of their own class. Yet, the strong anti-imperialist message they promoted enabled the Kál, the Kesari, and other nationalist papers to broaden their appeal—extending their influence to wherever Indians were restless for change. The papers proved particularly appealing to India's youth, who welcomed the chance to make their voices heard in a united challenge to the Raj. ${ }^{72}$ Moreover, given India's tradition of communal reading, it only required the

\footnotetext{
${ }^{69}$ Cited in Tahmankar, 27.

${ }^{70}$ Mahrátta, 17 April 1881.

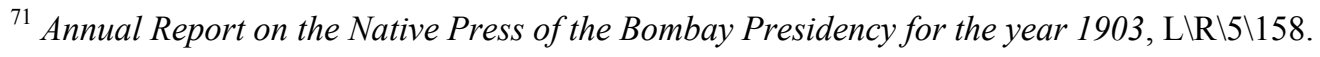


presence in a village of one literate person reading aloud to ensure the papers and their nationalist message would reach a new and ever growing audience.

What was becoming of particular concern to the Government during the last decades of the nineteenth century and at the dawn of the twentieth century was the emergence in India of tactics heretofore employed only by the Irish, such as the No-Rent strategy adopted by Indian peasants. In later years, Lord Hamilton — who had ordered the arrest of Tilak in 1897-lamented the growing influence of Ireland on Tilak and his fellow nationalists, stating, "I sometimes used to think that Tilak and Co. had got the idea into their heads. The Irish methods and the organization of the Land League have been closely studied by certain irreconcilables in Poona; and their proceedings were not dissimilar from those practiced by the Parnellites." ${ }^{, 73}$ Hamilton was no doubt referring to Poona's Chitpavan Brahmins, a highly-educated class of Hindus-among whom Tilak and Kál editor Paranjape were certainly the most vocal. As excerpts from the Mahrátta, Kesari, and Kál indicate, both men repeatedly cast their eyes toward Ireland, evincing an appreciation for Parnell's strategy of boycott and obstruction that would flourish in India after the Partition of Bengal.

That officials detected an Irish influence on the Indian populace was a direct result of the Indian native press disseminating Irish ideas among its readership. This imitation should not have come as a surprise to British officials, given the propensity of Brahmins to send their offspring to England for a proper British education. In the waning

\footnotetext{
${ }^{72}$ Sedition Committee Report, 13.

${ }^{73}$ Cited in Cashman, 143-144. Hamilton's memoirs indicate his growing concern about the emergence of an organized and charismatic Indian leader who would further adopt Irish methods of protest. "I wonder if, in the course of the next generation or two," he stated, "a Parnell will arise who will combine the ryots in refusing to pay land revenue."
} 
decades of the nineteenth century, Britain's most prestigious public schools, universities, and institutions — including Harrow, Cambridge, and the Inns of Court—had played host to the progeny of India's more affluent families. In what would ultimately be an irony of historical timing, their residence in the United Kingdom coincided with Ireland's bitter struggle to achieve what would come to be known as the three F's: Fair rent, Fixity of tenure, and Free sale. The Indian students thus observed the effectiveness of the twin strategies of boycott and obstructionism - perhaps the most beneficial lessons from a nationalist perspective they took with them back to India. ${ }^{74}$ Indeed, Sri Aurobindo Ghose, who together with Bipin Chandra Pal would found Bande Mataram in the wake of the partition of Bengal in 1905, was one of the students studying in England in 1870 when Parnell rose to power. ${ }^{75}$ Having observed the Irish protests against Captain Boycott, Ghose would later define the tactic as "an act of self-defence, of aggression for the sake of self-preservation. To call it an act of hate is to say that a man who is being

\footnotetext{
${ }^{74}$ Among those who studied in England were Sri Aurobindo Ghose, who began his studies in 1870, and Nobel Laureate Rabindranath Tagore, who arrived in 1878. Later arrivals to England's shores included Mohandas K. Gandhi (1888), who would study law; Muhammad Ali Jinnah (1892), the first GovernorGeneral of Pakistan, who joined Lincoln's Inn in 1894; and Jawaharlal Nehru, the first Prime Minister of India, who enrolled at Harrow in 1905.

${ }^{75}$ Charles Stewart Parnell's highly original political weapon of choice was the boycott, the eponymous campaign directed at Captain Charles Boycott, the British estate agent for the absentee landowner, the Earl of Erne, in County Mayo. Boycott's high rents and eviction of poorer Irish tenants earned him the enmity of the Irish populace. Under pressure from Parnell and his constituents, Captain Boycott was unable to hire workers for his Irish farm or find an Irish market for his produce. Refusing to condone any form of violent retribution against Boycott, Parnell had instead condemned him to what he aptly called a "moral Coventry," asserting: "There is no man so full of avarice, so lost to shame, as to dare the public opinion of all right thinking men." Charles Stewart Parnell, 10 September 1880. Cited in Charles Stewart Parnell, Princess Grace Irish Library. Internet; available from http://www.pgil-eirdata.org $/ \mathrm{html} / \mathrm{pgil}$ datasets/authors/p/ Parnell,CS/life.htm; accessed 18 November 2003. Not only did boycott become a staple of Indian protest, but the appeal by Parnell to British conscience bears a striking resemblance to the moral rectitude upon which Gandhi came to depend in his subsequent dealings with the British government.
} 
slowly murdered, is not justified in striking at his murderer." ${ }^{, 76}$ Ghose's position sought to deflect the criticism of those who accused nationalists in Ireland and in India of adopting tactics fueled solely by animosity toward the Empire. Instead, Ghose suggested that Irish — and, by extension, Indian resistance — was simply a matter of self-preservation. Nationalist journalists in both countries shielded themselves behind this argument, avowing that their often merciless critiques of British conduct in the Boer War and Boxer Rebellion were driven not by enmity, but arose only out of profound concern for the fate of their respective countries.

If the most outspoken Indian critics of the Empire emerged in the 1880s, a volatile blend of journalism and politics was established in Ireland as early as the mid-eighteenth century, with the founding of the Freeman's Journal by Charles Lucas in 1763. Considered the oldest nationalist paper in Ireland, the Freeman's Journal was a proponent of legislative independence for Ireland. As such, the paper adhered to the Protestant politics of Henry Grattan and Charles Flood, who advocated the creation of an Irish parliament distinct from Westminster. With the founding of Charles Stewart Parnell's Irish Parliamentary Party in 1882, the Freeman's Journal became even more ardently nationalist in its role as the Party's mouthpiece, until the Katherine O'Shea divorce scandal caused a schism among Irish Parliamentarians and the readership of the Journal. ${ }^{77}$

\footnotetext{
${ }^{76}$ Cited in Prof. Haridas Mukherjee and Prof. Uma Mukherjee, Sri Aurobindo's Political Thought 18931908 (Calcutta: Firma K.L. Mukopadhyay, 1958), 46.

${ }^{77}$ Parnell was named as co-respondent in the 1889 divorce proceedings between Captain William O'Shea - a Catholic Nationalist - and his wife Katherine. The subsequent fallout from the scandal caused a bitter rift between those in the party who deserted Parnell and members who staunchly supported him. Parnell lost the leadership of his party and died a broken man in 1891, just months after marrying O'Shea.
} 
Notably, the majority of early nineteenth-century papers in Ireland not only adhered to a specific political agenda, but also aligned themselves with a religious affiliation. Whereas in 1810, every one of the dozen newspapers published in Dublin were owned by Protestants, the emergence on the political scene of Daniel O'Connell would soon begin to shift the balance. ${ }^{78}$ If there was a paper that superseded the Journal in its unabashedly unapologetic championing of the nationalist cause, it was the Nation, founded in 1842 by Charles Gavan Duffy, Thomas Davis, and John Blake Dillon, members of the movement known as Young Ireland. M.L. Brillman has challenged the accepted characterization of Young Ireland as a revolutionary undertaking, however, arguing that "the weapons of the Young Irelanders in the 1840s were not the pike or the rifle, but rather the words and ideas they formulated in their remarkable newspaper, the Nation." ${ }^{, 79}$ Just as the Freeman's Journal had railed against the passage of the Act of Union in 1801, so did the Nation exist almost solely to promote the agenda of the Repeal Association, founded by the fiery orator Daniel O'Connell, in 1840. Brillman suggests that the Nation "was a crucial instrument in linking Repeal to the Irish people," and left as its legacy a tradition of "moral force, constitutional politics, and unequivocal loyalty to

\footnotetext{
${ }^{78}$ For more on this shift from Protestant ownership, see Stephen J. Brown, The Press in Ireland: A Survey and a Guide (Dublin: Browne and Nolan Limited, 1937). Brown provides the political and religious affiliation of each of Ireland's newspapers, and pays particular attention to the founding of the Nation in 1842, United Ireland in 1881, and the United Irishman in 1899. John S. North's The Waterloo Directory of Irish Newspapers and Periodicals, 1800-1900 Phase II (Waterloo: North Waterloo Academic Press, 1986) provides a similar survey of nineteenth century Irish newspapers, and catalogues not only the subject matter of each paper, but also the names of editors and printers. An earlier work, R.L. Munter's A Handlist of Irish Newspapers 1685-1750 (London: Bowes \& Bowes, 1960) chronicles the advent of the Irish press, with the publication of the Irish Monthly Mercury in 1649, and surveys other key seventeenth and eighteenth century papers.

${ }^{79}$ M.L. Brillman, "Loyalty and Repeal: The Nation, 1842-46," in Irish Journalism Before Independence: More a Disease than A Profession (Manchester and New York: Manchester University Press, 2011), 36.
} 
O'Connell., ${ }^{, 80}$ The Nation was the first newspaper in Ireland to formally function as a mouthpiece for a nationalist political agenda — a role later assumed by the Freeman's Journal, in its staunch advocacy of the Irish Parliamentary Party.

Perhaps the most incendiary writer for the Nation was John Mitchel, another Young Irelander. Although Mitchel would only contribute to the paper from 1845 to 1847, he managed in that short time to embroil the Nation in a charge of seditious libel. In 1848, John Mitchel founded his own nationalist journal, the United Irishman, whose rabid anti-British views speedily earned it the enmity of the British Government. ${ }^{81}$ In May of 1848, a mere three months after the inaugural publication of the paper, Mitchel found himself tried and convicted of treason-felony and sentenced to deportation. ${ }^{82}$ Long after his exile from Ireland, Mitchel continued to be a thorn in the side of the British and a formidable presence in the press. Writing about Britain in the New York Times at the onset of the Crimean War, Mitchel proclaimed, "The Enemy's difficulty, though they try to disguise and make light of it, is come. Shall it be to Ireland an

\footnotetext{
${ }^{80}$ Ibid.

${ }^{81}$ The name United Irishman resonated with the reading public in Ireland-recalling the exploits of the renowned Irish revolutionary Wolfe Tone (1763-1798), who co-founded the Society of the United Irishmen and subsequently participated in the 1798 Irish Rebellion.

${ }^{82}$ While imprisoned, Mitchel began writing his seminal work, Jail Journal, which the 1916 Easter Rising leader Padraic Pearse would later refer to as "the last gospel of the New Testament of Irish nationality, the last and the fieriest and the most sublime." Bryan P. McGovern, John Mitchel: Irish Nationalist, Southern Secessionist (University of Tennessee Press, 2009 ), 238. The 1913 edition featured a preface penned by Arthur Griffith, who offered effusive praise for Mitchell, saying, "To the end of his days Mitchel remained the fearless speaker of truth as he conceived it, regardless of personal consequences, and the foe of humbug no matter what its garb." Arthur Griffith, Preface to Jail Journal of John Mitchel (Dublin: M. H. Gill \& Son 1913), pgs..ix-xvi.
} 
opportunity? — and how?" ${ }^{83}$ Thus did Mitchel set the agenda for all current and future Irish nationalists who proudly bore that name, whether in the press or in politics.

In the 1870s, William O'Brien surged to the forefront of Irish nationalist editors, embracing the Irish Land War as the perfect conflict to rouse his readership. A Member of Parliament whose proudly contentious newspaper United Ireland (1881) boasted that it was an "insurrection in print," O'Brien co-authored with fellow nationalist John Dillon the notorious 1886 Plan of Campaign, which sought to convince struggling Irish tenant farmers to withhold rent from their absentee landlords until the landlords agreed to reduced rents. Eschewing the "cringing servility" adopted by those who shepherded rival Dublin newspapers, O’Brien did not hesitate to skewer British policy at every conceivable turn. When Dublin Castle attempted to suppress the paper, O'Brien cheekily responded by inserting a tombstone in every issue of the paper, with an epitaph which read "Freedom of the Press in Ireland in 1881." $"$ In addition to gaining the attention of Dublin Castle, this impudent act served to remind United Ireland's readers that Britain was denying to the Irish rights guaranteed to every citizen of the Empire.

In the 1870s and 1880s, the Freeman's Journal, the Nation, and the United Ireland kept their readers fully apprised of debates in Westminster; international events in India, Africa, and the Middle East; and the intricate chess moves by Parnell and his party as they tried to wrest control of Irish property from the British. The strategy was not exclusively altruistic; in their reportage, they clearly sought to align their readers'

\footnotetext{
83 "England and the Irish," New York Times, 23 March 1854.

${ }^{84}$ United Ireland, 29 October 1881. Upon his retirement from Westminster, O'Brien remained as politically active as ever, co-founding the United Irish League with Michael Davitt, and founding the movement's paper, the Irish People.
} 
attitudes toward the British Government with their own. Irish nationalist journalists sought to influence public opinion and also reflect public opinion, thereby giving a voice to thousands of middle and lower-class citizens who otherwise would have lacked an advocate.

The most striking Irish exemplar of a politician-journalist, however, was Arthur Griffith, co-owner and editor of the United Irishman, and future founder of the Sinn Féin movement. Griffith had toiled as a compositor on the Nation, before enlisting on the Irish Independent as a copyreader. In 1899, freshly returned from South Africa-where he managed to found, publish, and dismantle a newspaper in a swift thirteen issuesGriffith joined with his friend, William Rooney, to publish the United Irishman. The journal was the second Irish publication to boast that particular name, having borrowed its moniker and its manifesto-“'Ireland for the Irish"—-from John Mitchel's journalistic experiment in the $1840 \mathrm{~s} .^{85}$

With the advent of the Irish Parliamentary Party, most nationalist newspapers supported the Party's constitutional efforts. Just as the Nation had been the official organ of Daniel O'Connell's Repeal movement, the Freeman's Journal became the mouthpiece of the Irish Parliamentary Party, working toward the goal of Home Rule through British legislative channels. Griffith summarily rejected that position, proposing instead a bold new Irish Nationalism. Just as Tilak and Paranjape pursued a more extreme nationalism in India, Griffith's brand of "advanced-nationalism" distanced itself from the more traditional Irish nationalist papers, in that it believed the constitutional methods of the

\footnotetext{
${ }^{85}$ Ibid, 45-6.
} 
Irish Parliamentary Party would prove futile in winning Ireland its independence. ${ }^{86}$

Advanced-nationalist journalists, who included James Connolly and D.P. Moran among their ranks, were unwilling to settle for Home Rule, and vociferously espoused the cause of full Irish independence. Dismissing the Home Rulers claim to patriotism, Connolly charged, "future history will more correctly stigmatise them as the most unscrupulous political charlatans who ever imposed upon a confiding race. ${ }^{\$ 77}$ Connolly was particularly irritated by the news that an assembly of nationalist journalists gathered at the Irish Institute of Journalists had drunk a toast to the Queen, rather than to freedom for Ireland. For his part, Griffith declared, "Though I am a believer in the republican system of government, I am ready — as I believe is every other Irish Nationalist— to accept any form of native government in preference to alien rule. ${ }^{.88}$ Griffith expended an inordinate amount of energy alternately trying to win over—or fend off—-the parliamentarians gathered to his right, and the physical force men aligned on his left.

Like Tilak, Griffith pressed for self-government, and insisted on a program of national education that focused on native history and culture. In the inaugural issues of the United Irishman, Griffith and Rooney set the tone for the years to come, aggressively pursuing a nationalist agenda, calling for a "plague on the slaves who preach that Irishmen should be influenced in their actions or conduct by English opinion." ${ }^{89}$ Just as

\footnotetext{
${ }^{86}$ Glandon's analysis of the advanced-nationalist press demonstrates the disparate agendas of those organs that adhered to the constitutional program of the Irish Parliamentary Party, those who sought an independent Ireland, and those who would ultimately align themselves with the physical force faction.

${ }^{87}$ James Connolly, "Home Rule Journalists and Patriotism: An Object Lesson," in Workers' Republic, 13 August 1898. Internet; available at http://www.marxists.org/archive/connolly/1898/08/journalists.htm; Accessed on 23 March 2013.

${ }^{88}$ Cited in Padraic Colum, Arthur Griffith, (Dublin: Browne and Nolan Limited, 1959), 53.
} 
Tilak had lampooned the members of the Indian National Congress as dispirited, unambitious, and cowardly, so too the United Irishman launched an attack on the complacency of the Irish in the face of their subjugation by the British, denouncing the "vile, skulking, servile spirit abroad—a lying, dastardly spirit—sometimes disguising itself as a patriotic spirit." ${ }^{, 90}$ To underscore the need for a revival of Irish industry, Griffith reminded his readers of Jonathan Swift's admonition to "Burn everything English except their coals." ${ }^{91}$ Although the United Irishman was only in print for six years, during that time Griffith managed to set before the public what would soon be embraced as the basic tenets of Irish nationalism, including the all-important goal of depending on “ourselves alone:" Sinn Féin.

\section{Assessing the Impact}

Whereas the nationalist press in both India and Ireland was undeniably aggressive in promoting an agenda, there exists the lingering question of whether that outspokenness translated into increasing support for the cause. In her study of Irish coverage of the Indian Mutiny, Jennifer Regan argues that although newspapers cannot reveal the thoughts of readers, "they should reveal what kind of information was available to the literate public who did not have imperial knowledge through first-hand accounts. ${ }^{.92}$ In

\footnotetext{
${ }^{89}$ United Irishman, 25 March 1899.

${ }^{90}$ United Irishman, 4 April 1899, cited in Brian Maye, Arthur Griffith (Dublin: Griffith College Productions, 1997), 56.

${ }^{91}$ United Irishman, 8 July 1899. "Burn everything English but their coal" was the mantra of the great Irish satirist Jonathan Swift (1667-1745). The line made its initial appearance in 1724, in the first of the seven pamphlets known as the Drapier Letters. Swift's admonition was a slogan subsequently adopted by Sinn Féin. Internet; available at http://www.usna.edu/EnglishDept/ilv/swift.htm; accessed 7 December 2003.
} 
the case of imperial conflicts waged in foreign countries, the majority of the public received news of the wars almost exclusively through the press, which took advantage of the opportunity to filter the news through its own political sensibilities. Papers loyal to the British Government relayed the Government's press releases intact, whereas those extremist or advanced-nationalist papers in opposition openly questioned the veracity of the updates, and sought to spin an alternate reality for their readers. "By sheer virtue of what it chose to report on, what it chose to ignore, and topics it chose to privilege," asserts Michael de Nie, "the press shaped the public conversation and helped set the political agenda. ${ }^{.93}$ During an age in which the newspaper functioned as the primary form of mass media, nationalist editors understood that they possessed an extraordinary public forum from which to direct the public debate. The artful cherry-picking of war news enabled Irish and Indian editors to determine the contours of the discussion, ensuring that the Empire's conduct was always under scrutiny.

The question remains as to whether Arthur Griffith and Bal Gangadhar Tilak and their colleagues managed to make substantive inroads in directing the national conversation. While no single criterion can reliably reveal the full dynamics of the era, analysis of four critical factors - circulation figures, editorial content, government correspondence, and government legislation—can illuminate the growth of the nationalist press, as well as Britain's increasingly futile attempt to suppress its influence.

Circulation figures for the Irish papers tell a story of remarkable expansion, with the Gray family growing the Freeman's Journal from a mere 2000-3000 copies in the 1840s to a

\footnotetext{
${ }^{92}$ Jennifer M. Regan, "We Could Be of Service to Other Suffering People," Victoria Periodicals Review, Volume 41, Number 1 (Spring 2008), 62-63.

${ }^{93}$ De Nie, 887.
} 
staggering 30,000 copies a day — an estimated forty percent of the market — by the 1880s. ${ }^{94}$ Just as significant was the dramatic rise in the number of Irish papers that took on the nationalist label. Whereas only two newspapers donned the mantle of nationalism in the 1840 s, twenty-eight were waving the nationalist banner by the end of the nineteenth century. ${ }^{95}$

Although circulation figures provide a factual foundation for analyzing the reach of the Irish nationalist press, in India they reveal only a fraction of the story. Inasmuch as the Government of India regularly kept the circulation figures on the leading papers of the day, these figures undoubtedly underestimated a paper's readership. The pattern was a peculiarity of Indian life that Sir John Edgar, Chief Secretary to the Government of Bengal, deemed necessary to explain at great length to his superiors. In a revealing memo to the Secretary of the Government of India, Edgar advised, "It is not to be supposed that the influence of the papers can be measured solely by the number of their subscribers ... Statistics apart, these newspapers are widely circulated from hand to hand; they are read aloud to circles of listeners; the statements made in them are repeated by readers or listeners to others." 96 Advising the Government that a paper with 300,000 copies in circulation could ultimately reach an audience of two million, Edgar also

\footnotetext{
94 “The Freeman's Journal," National Library of Ireland; Internet; accessible at http://www.nli.ie/blog/index.php/2012/08/21/thefreemansjournal/; accessed on 27 January 2013.

${ }^{95}$ Source: $19^{\text {th }}$ Century British Library Newspapers digitised collection. Cited in Andrew Hobbs, "When the Provincial Press Was the National Press, c. 1836-1900;" Internet; Available at http://www.academia.edu/187659/When_the_provincial_press_was_the_national_press_c.1836-1900_; Accessed on 27 January 2013. For detailed circulation numbers compiled by Dublin Castle on the provincial press in Ireland, see Legg, 31, 127.

${ }^{96}$ Letter from the Government of Bengal, Sir John Edgar to the Government of India, Home Department, Calcutta, 20 April 1891, IOR $\backslash L \backslash P J \backslash 6 \backslash 303$. No. 1726-J, India Office Records, British Library.
} 
warned that the number multiplied dramatically whenever the native press broached a subject steeped in controversy. ${ }^{97}$

As Edgar's memorandum indicates, an analysis of official records and correspondence sheds revealing light on the impact of the Irish and Indian press, demonstrating the Government's perception of how efficient and effective editors were in reaching their targeted audience. Secret correspondence emanating from Dublin Castle and the offices of the Government of India indicate that as much as officials would have liked to dismiss out of hand the efforts of nationalists, the journalists' output was causing considerable anxiety and nervousness. Dublin Castle records showcase Britain's grave concern about the Irish nationalist press, with the question of what constituted sedition clearly preoccupying officials, who were quick to order the suppression of Irish papers at the slightest provocation. On the subcontinent, officials serving in the Government of India felt compelled to put into writing every thought and opinion- however biased or ill-developed - regarding the native press. In and of themselves, the flurry of minutes, memoranda, letters, and cables detail the palpable concerns and fears of the government. The prolific correspondence, coupled with the resulting legislation aimed at suppressing Indian journalists, are essential tools in analyzing the Government's perception of public opinion.

That officials were growing increasingly concerned about the potential danger posed by the nationalist press can be borne out by the legislation designed by the British

${ }^{97}$ Ibid. This circulation pattern elicited negative reaction from a variety of sources. Writing in the Calcutta Review, the anonymous author TRUTH noted that some of the more aggressive papers often enjoyed the highest circulation and that circulation figures often trebled that of British papers. Moreover, the author expressed fear that the accepted circulation figures "by no means fully represent the numbers who actually read and imbibe the poison." TRUTH, "Why the Native Press Should Be Licensed," in Calcutta Review, January 1900, Volume 110. 
Government to rein in inflammatory rhetoric in the newspapers. If there is a credible case to be made for the power of the nationalist press in this era, among the most convincing evidence remains the tortuous legal maneuvers undertaken to suppress the Empire's vocal critics. ${ }^{98}$ The Council of India was convinced that India's native press was guilty of "breathing disaffection and sedition among the ignorant masses," while Sir Frederick W. Heygate alerted his confreres in Westminster that Irish journalists were guilty of "incalculable mischief." " 99 By the 1870s, government officials in both Ireland and India were confronting an increasingly bold and vocal press that was testing the limits of Britain's liberalism. The miasma of uncertainty and unease pervading the corridors of power ultimately persuaded the Government to produce the Peace Preservation (Ireland) Act of 1870 and the Vernacular Press Act of 1878 - a potent pair of predictably reactionary bills, more illustrative of mounting British paranoia than of any real peril from Irish and Indian printing presses. Ostensibly concocted in an attempt to stop the outpouring of nationalistic fervor, the legislation not only failed to silence critics of imperial policy, but rather it served as a spur, urging newly invigorated journalists in Ireland and India to accelerate their protests.

In Ireland, just as the nationalist press had exploited the issue of land agitation to promote sales of its newspapers, so did the British Government seize on what it deemed

\footnotetext{
${ }^{98}$ In Ireland, alone, Charles Gavan Duffy of the Nation was twice tried for sedition, while John Mitchel was tried and convicted of felony-treason. Among the Irish newspapers that were suppressed by the British Government through the turn of the century were The Nation (1848), the Irish Felon (1848), the Irish Tribune (1848 - suppressed after only five issues) the Irish People (1901), William O'Brien's United Ireland (1881, 1890-91) and Arthur Griffith's United Irishman (1901, 1902, 1903, 1904, 1905, 1906).

${ }^{99}$ Cited in Council of India. Opinions, and Reasons for the same, entered in the Minutes of Proceedings of the Council of India, relating to the Vernacular Press Act, 1878 Lytton Collection, MSS EUR E218/146, India Office Records, British Library. The charge was leveled by Sir Frederick W. Heygate, during debates in the House of Commons on the Peace Preservation (Ireland) Bill, 17 March 1870. Hansard Parliamentary Debates, series 3, vol. 200, (1870), col. 106-108. Internet; available at http://hansard.millbanksystems.com/commons/1870/mar/17/leave-first-reading; accessed on 22 May 2013.
} 
the recklessness of Irish journalists as it rationalized the necessity of legislating the press. Upon hearing of the Government's plans, Philip Callan, Member of Parliament for Dundalk, leveled a bitter charge at the Government, indicting officials for promulgating a "fictitious panic from agrarian outrage," merely for the purpose of enacting repressive legislation designed to rein in the press. ${ }^{100}$ In fact, the Peace Preservation (Ireland) Act of 1870 featured legislation that would come to be known as the Irish Press Act, which called for Dublin Castle to confiscate the print equipment of any Irish journal suspected of publishing articles promoting sedition. During the lengthy debate over the bill, Chief Secretary for Ireland Chichester Fortescue rose to denounce forcefully the writings of the Irish press, declaring, "It is well known how it teaches and preaches in every form, with an amount of boldness and audacity varying from week to week and from month to month, hatred of the institutions and Government of the United Kingdom."101 The Irish Land War had spawned a new and decidedly more entrenched generation of nationalists, who resented and rejected British domination and saw no reason to disguise their animus toward Britain.

In a ringing dismissal of the intellectual powers of the naïve Irish peasant, who presumably read and swallowed whole the meaty output of the nationalist papers, Fortescue drove home the need to muzzle the troublesome Irish press. The Secretary declared, "It is known how that weekly literature poisons the minds of the people in Ireland who read it against all law and against the Constitution of the country ... how it

\footnotetext{
${ }^{100}$ Hansard Parliamentary Debates, The Peace Preservation (Ireland) Act, 1870. series 3, vol 200, col. 335336. Internet; available at http://hansard.millbanksystems.com/commons/1870/mar/21/second-readingfirst-night\#S3V0200P0_18700321_HOC_45; accessed on 22 May 2013.

${ }^{101}$ Ibid, col. 100
} 
inflames the passions of the people by the rhetorical descriptions of the wrongs of other days ... how it makes it impossible for those who read that literature, and read none other, to know the truth with respect to public affairs and the real conduct and intentions of the Government of the country." Government's anxiety about the power of the press to "educate." Whereas educating the public was certainly a noble journalistic calling, the British Government was leery of the lessons gleefully taught by a nationalist press all too capable of schooling their readers in the subject of discontent.

Asserting that "our object is not so much to punish the individuals as to stop the evil itself," the Peace Preservation (Ireland) Act of 1870 granted officials not only the authority to prosecute an editor for seditious libel or treason-felony, but also gave the Lord Lieutenant power to seize all copies of any paper deemed offensive. ${ }^{103}$ Such sanctions met with fierce disapproval from several of those sitting in Westminster, with Sir John Gray characterizing the legislation as a series of "unreasonable proposals" that "had never been heard of in the most repressive bill ever devised." 104 The Solicitor General, Mr. Dowse, countered such arguments with his rather stunning assertion that the proposed bill was "a measure of real kindness, for the sooner the Irish people were made to understand that they must obey the law, and that it would protect right and punish wrong, the better it would be for Ireland and the Empire at large." ${ }^{, 105}$ Such myopic vision of an Irish people so docile as to submit willingly to the legislative whims of the Empire
${ }^{102}$ Ibid.
${ }^{103}$ Ibid, 101-102.
${ }^{104}$ Ibid, 122.
${ }^{105}$ Ibid, 127. 
reveals a British Government increasingly removed from political reality. British failure to comprehend the Irish character is all the more surprising given the geographical proximity and long history of governance.

The debate was both heated and prolonged, with those who backed the legislation reading aloud passages from offending papers, while those who opposed the measure accused the Government of arming itself with repressive and "unconstitutional powers, for the purpose of striking at the liberty of the press. ${ }^{„ 106}$ Going further, Mr. Moore denounced the legislation for striking not only at the liberty of the press, "but at the very life of a nation." ${ }^{\prime 107}$ There were many in Westminster who feared that the proposed Press Act would fly in the face of Britain's vaunted liberalism, whittling away at a freedom long cherished by its people. "While other nations, comparatively new to liberty," were learning, by courageous experiment, that order and law might be maintained without a censorship of the Press," charged Mr. W.M. Torrens, "it was painful to think that a British Parliament should be invited to revert to arbitrary devices and oppression powers. $" 108$

In an attempt to deny the necessity of such legislation, Mr. John Gray pointed to the successful prosecutions under the Treason-Felony Act of John Mitchel and the United Irishman, as well as the shutting down of the Felon and the Tribune. Gray decried the proposal to grant unlimited power to the Government- "which in Ireland meant three or

\footnotetext{
${ }^{106}$ Ibid, 371.

${ }^{107}$ Ibid, 386.

${ }^{108}$ Ibid, 630.
} 
four legal gentlemen ensconced in a dark room in Dublin Castle." ${ }^{109}$ In his estimation, the legislation gave such men leave "to constitute themselves a worse than Star Chamber, and to control the entire Press of the country." ${ }^{\prime 10}$ Gray's reference to the notorious Star Chamber — as secretive and arbitrary as it was speedy in its pronouncements—was an attempt to remind Parliament that such monarchical highhandedness had long been rejected by the British people. ${ }^{111}$

Such words sent an unmistakable signal to the Irish nationalist press that the Government had ceased to obey its constitutional mandate and would prosecute its critics with a heretofore unknown ferocity. That same prescience warned that the inevitable outcome of such repression would be renewed — and even more violent—protests by those in the nationalist press clinging desperately to their rights as subjects of the Empire. Yet, the words of Moore and Torrens and Gray would fall on deaf ears, and the Peace Preservation (Ireland) Act with its repressive Irish Press Act, would be enacted into law in the spring of 1870 .

Ireland served as a legislative laboratory for the Empire, a backyard Bunsen burner in which to empirically test the potency of the newest law governing the land, the schoolroom, or the newspaper. Having dutifully enacted repressive legislation to respond to Irish agitation in the press, Westminster proactively resorted to the same harsh measures in an effort to smother what they perceived as incipient Indian defiance.

\footnotetext{
${ }^{109}$ Ibid, 667.

${ }^{110}$ Ibid.

${ }^{111}$ The Star Chamber was instituted during the medieval era and was first actively used during the reign of Henry VII. Whereas the judicial body originally was held in some esteem, under subsequent rulersparticularly the Stuart kings - the Star Chamber was reviled by those fearing its overreaching power. The Habeas Corpus Act 1640, passed by the Long Parliament, abolished the Star Chamber.
} 
Indeed, there is reason to suspect that the introduction of the 1878 Indian legislation was as much an instinctive reaction to past agitation in Ireland as it was to present sedition in India. What the British Government failed to recognize was that the Indian native press was, by and large, demonstrably loyal. Since the 1857 Mutiny, there had been no overt attempt at agitation, let alone any massive uprising. Even the editorials in the native press generally hewed to a tone of gentlemanly remonstrance, learned and practiced since infancy at the knee of that most civilized of Empires. In 1870, the Irishman had poised the sword of Damocles over the head of the British Government, threatening ominously, "There are 100,000 men in the country to-day [sic] who are ready, if necessary, to go to the fullest extent for its liberty." By contrast, the Indian native press spoke of "discontent in the minds of the people. ${ }^{p 12}$ Exceptions to this editorial etiquette did, indeed, exist, prompting the Government to launch sedition proceedings. ${ }^{113}$ The majority of the native press, however, couched their criticisms in the most elegant and eloquent of prose, seeking to chide and chastise, rather than excoriate.

The absence of violent language did not the stop the Government of India from rigorously monitoring the Indian native press. In 1874, intelligence officials instituted a new practice of employing native speakers to pore over each issue, and excerpt what they deemed were the most inflammatory of articles. ${ }^{114}$ No area of Indian life was omitted,

\footnotetext{
${ }^{112}$ Irishman, 16 October 1870; Induprakásh, 4 June 1877, cited in John Dacosta, Remarks on the Vernacular Press Law of India, or Act IX. of 1878 (London: W.H. Allen and Co., 1878), 7-8.

${ }^{113}$ For a discussion of the Government's 1891 prosecution of the Bangabasi, see Marc Jason's Gilbert's dissertation, Lord Lansdowne in India: At the Climax of an Empire, 1888-1894, A Study in Late Nineteenth Century British Indian Policy and Proconsular Power (Los Angeles: University of California, 1978), 35962.

${ }^{114}$ Just as the Government of India could not guarantee the fidelity of these translations to the newspaper under investigation, so the modern researcher cannot vouch for the accuracy of these sources. For the
} 
with summaries of articles on agriculture, famine, education, and railways dutifully compiled. In a telling sign of their growing anxiety, officials would soon request that the heading of Ireland be added to the list of excerpted articles, in a bid to keep track of the developing brotherhood between Irish and Indian nationalists. Richard Davis has suggested that the sheer numbers of articles translated by intelligence officials is a potent indicator of "the seriousness with which the British authorities regarded Irish-Indian relations in this period." ${ }^{115}$ Certainly, the evidence supports his conclusions, with Irish and Indian nationalist editors repeatedly bolstering their own agendas by alluding to each other's nationalist strategy. ${ }^{116}$ The Government of India could not have been pleased to read excerpts detailing "Alleged necessity of a combination between India, Ireland, and South Africa in the struggle against British oppression" or "Exhortation to the people of India to imitate Russian and Irish methods of political agitation." 117

In addition to these weekly Reports on the Native Press, the Political Department of the Bombay Presidency also commissioned an Annual Report on the Native Press, which documented the "attitudes and activities" of the leading news organs. The detailed report meticulously catalogued the number of papers, circulation figures, and, in particular, the tone of the native press in its treatment of both domestic and foreign policy. Officials in the Bombay Presidency classified the newspapers according to the

\footnotetext{
English language speaker, however, they remain one of the only windows into the journalism of the Indian native press in this era.

${ }^{115}$ Davis, "The Evidence of the Indian Press," 55.

${ }^{116}$ This exchange of ideas would reach its apex with the near-simultaneous birth of the Swadeshi and Sinn Féin movements

${ }^{117}$ Mahráita, Poona, 21 January 1906 and Vihári, Bombay, 5 November 1906. From Weekly Report, $\mathrm{L} \backslash \mathrm{R} \backslash 5 \backslash 161$.
} 
loyalty expressed within their pages, devising four categories into which the papers could be carefully slotted. The safe, "innocuous" papers were those that eschewed any talk of politics, while a second category remained loyal at all times to the Empire. ${ }^{118}$ The remaining two categories were much more problematic, representing those nationalist papers who hewed closely to the agenda of the Indian National Congress, and those Marathi papers—of which the Kesari and the Kál were the most prominent—-that adopted a more radical tone and were "animated by a spirit of hostility to British rule."119 Indeed, these last two categories were analogous to Ireland's always disagreeable advancednationalist press - a troubling similarity that may have induced officials in India to be proactive in stifling the native press.

Britain's distrust of the Indian press dated back to well before the Indian Mutiny, with a succession of laws mandating licensing of newspapers or threatening suppression, including Press Acts in 1835 and 1867. The issue of whether the revered British tradition of freedom of the press should be extended to Indian journalists had long been a subject of debate, arising on any occasion of native protest. ${ }^{120}$ Many in authority refused to believe that criticism of the government was harmless or could even be beneficial in identifying legitimate native grievances, and accused the government of being far too

\footnotetext{
${ }^{118}$ Annual Report on the Native Press of the Bombay Presidency for the year 1903, L $\backslash \mathrm{R} \backslash 5 \backslash 158$. ${ }^{119}$ Ibid.

${ }^{120}$ During the height of the "Half-Bhatta" protests - arising from the East India Company's decision to order a pay cut for army officers-William Butterworth Bayley fretted that without fear of Government prosecution, "factious individuals" would feel free "to disseminate the most mischievous reports through the public papers and injuriously to affect the influence and proper authority of Government over its own servants, its army and its native subjects." Lord Bentinck, while espousing respect for the liberty of the press, declared that such liberty should be suspended if it threatened the safety of the Empire. Minute from William Butterworth Bayley and Lord Bentinck, 6 September 1830. Cited in Barns, 193.
} 
tolerant of the incessant vituperative volleys launched by journalists. Only Supreme Council member Sir Charles Metcalfe consistently spoke out against any interference with the native press, believing it preferable to let subjects vent their anger, rather than "forcing them to smother it within their own breasts, ever ready to burst out."121

Metcalfe's liberal stance on the native press earned him the enmity of his fellow officials in the East India Company, and he resigned from service in 1838.

In the wake of the Indian Mutiny of 1857 , the Government of India instituted the “Gagging Act," (Act No. XV of 1857), which mandated licensing of all printing presses. Indeed, Lord Canning, India's first Viceroy (1858-1861), made no secret of his disdain for the native press, openly sharing his scorn with the Legislative Council: "I doubt whether it is fully understood or known to what an audacious extent sedition has been poured into the hearts of the native population of India within the last few weeks under the guise of intelligence supplied to them by the native newspapers." ${ }^{122}$ Yet, "Clemency Canning" scrupulously avoided permitting his bias to seep into new legislation, stating: "I do not see any reason, nor do I consider it possible in justice to draw a line of demarcation between European and Native Publications." ${ }^{123}$ Canning was among the last of the Viceroys to take such an evenhanded approach toward the vernacular press.

\footnotetext{
${ }^{121}$ Minute by Sir Charles Metcalfe, 6 September 1930. Cited in Barns, 195.

${ }^{122}$ Cited in Margarita Barns, The Indian Press: A History of the Growth of Public Opinion in India.(London: George Allen \& Unwin, Ltd., 1940), 250.

${ }^{123}$ Ibid, 251. Canning earned his nickname during his tenure as Governor-General (1856-58), when he made a concerted effort to show mercy to the Indian sepoys who had participated in the Mutiny.
} 
Viceroy Lord Lytton (1878-1880) was not as accommodating-presiding over the Passage of Act IX of 1878, the Vernacular Press Act (India), designed to rein in India's most vocal critics of the Empire. ${ }^{124}$ Significantly, the Legislative Council of the Governor General drew liberally from the press provisions of the Peace Preservation (Ireland) Act of 1870 when devising their own legislation in India. ${ }^{125}$ Lytton, himself, characterized the 1870 Irish law as "very applicable to the circumstances of this country," an opinion shared by much of the Council. ${ }^{126}$ That the Council deemed the "Irish Press Law" a suitable remedy for India's vernacular press was an indication of how dangerously officials were misreading the position of the press in India. Fired up by agrarian strife, the nationalist press in Ireland was irate and irascible, uncompromising and uncooperative, combative and confrontational, whereas the Indian native press still comprised a relatively polite body of journalists. However much the nationalist fire burned within their breasts, with rare exceptions they comported themselves with the utmost civility, and carefully phrased their criticisms in the most gentlemanly of fashions.

\footnotetext{
${ }^{124}$ For an in-depth analysis of the impact of this polarizing piece of legislation, see Somnath Roy's "Repercussions of the Vernacular Press Act, 1878," Journal of Indian History, Vol. XLV, Part III, December 1967, No. 135, 735-748. Roy asserts that the bill not only shuttered certain publications, but also "transformed the character of a few, and caused the birth of some new ones." (744). Indeed, one year after the passage of the Vernacular Press Act, Surendranath Banerjea, the leader of the Indian National Association, founded the Bengalee, a decidedly nationalist paper. Roy relates the proceedings of the Calcutta Town Hall meeting organized in April of 1878 by Banerjea to protest the bill, and asserts that such resistance to the Act spurred the growth of middle-class nationalism.

${ }^{125}$ Minute by the Viceroy, 22 October 1877, in Copy of Correspondence between the Viceroy of India and the Secretary of State on the subject of Act IX of 1878. [hereafter referred to as Correspondence], Lytton Collection, MSS EUR E218/147, OIOC, British Library.

${ }^{126}$ Minute by the Viceroy, 22 October 1877, in Correspondence. 44. J.H. Morris, Esq., Chief Commissioner of the Central Provinces was among those who agreed with Lytton, believing the Irish Law to be a suitable template for legislation in India. Correspondence, 57, 62 .
} 
In providing a rationale for the repressive bill, Council member Alexander Arbuthnot revealed the contempt officials felt for the masses, characterizing those who read the vernacular press as "far more ignorant than those classes which are reached by the English Papers." 127 Therefore, Arbuthnot continued, the writings were "calculated to be much more mischievous in their effects... They influence and pervert the minds of the young, and go far to counteract the benefits of the education we are endeavoring to impart to them." 128 The startling similarity between Arbuthnot's dismissal of the Indian peasant and Chichester Fortescue's discussion of the gullibility of the Irish peasant provides more evidence that the British Government was attempting to apply the lessons of Ireland to India. For his part, Lytton feared that the vernacular press - "at all times mischievous"-would not long be satisfied with its attacks on Government policy, but would spearhead a movement to sever ties with the Empire. ${ }^{129}$ Confiding in the Secretary of State, the Viceroy shared his concern that the press was "especially dangerous now, when Native community believes our power seriously weakened by events elsewhere." ${ }^{, 130}$ Lytton was referring not only to the growing tension between Britain and Russia, but also to the start of a litany of thorny conflicts in which the Empire would soon find itself mired, including the Second Afghan War (1878-80), the Zulu War (1879), and the First Boer War (1880-81).

\footnotetext{
127 Correspondence, 13.

${ }^{128}$ Ibid.

${ }^{129}$ Telegram from the Viceroy of India to the Secretary of State, Calcutta, 13 March 1878, in Correspondence.

${ }^{130}$ Ibid.
} 
In what was to prove a catastrophic moment of miscalculation, the Viceroy thus convinced himself that the Vernacular Press Act would prove "quite unobjectionable."131 Solely on the basis of public reaction in Ireland to the 1870 Irish Press Law, this judgment would have been considered highly suspect. The law enacted by the Council, however, also differed from the Irish bill in a trio of very telling aspects. Whereas the Irish law was applicable to all newspapers, the 1878 Indian bill targeted only the vernacular press. In addition, the Irish bill was a temporary measure, enacted in a time of heightened agrarian agitation, while the Vernacular Press Act was proposed during a time of peace in India, and the law was designed to be permanent. The marked contrast in circumstances was not lost on Sir Thomas Erskine Perry (Council of India member 18591881), who felt the need to point out to the Council that the Irish law "was a temporary measure, passed to meet a temporary evil, and dropped by the present Government in 1874." ${ }^{.132}$ William Gladstone also objected to the use of the Irish Press Law as a precedent, reminding his fellow Parliamentarians that the Irish legislation "was never intended to bring about a permanent change in the status of the Irish Press; and, in the next place, and what is more important and vital in this case, we did not restrain the Irish Press for mere disaffection, but for the security of human life." ${ }^{\prime 13}$ It would seem that time and distance were the deciding factors in determining the attitude of liberal Parliamentarians to the Vernacular Press Act. Many of the same individuals who had been so exercised about the writings of the Irish press only eight years previously now

\footnotetext{
${ }^{131}$ Minute by the Viceroy, 22 October 1877, in Correspondence. 44

${ }^{132}$ See Opinions, p. 2.

133 "Motion for an Address," Hansard Parliamentary Debates, House of Commons, 23 July 1878, series 3 , vol 242, col. 56. Internet; available at http://hansard.millbanksystems.com/commons/1878/jul/23/motionfor-an-address\#S3V0242P0_18780723_HOC_56; accessed on 22 May 2013.
} 
called for patience and understanding in the Government of India's relations with the Indian native press. Moreover, the journalistic unrest in Ireland had been in England's backyard. Perhaps, it was easier to preach tolerance when the incendiary writings were thousands of miles away from Westminster.

Predictably, the response from the Indian native press was indignant, incensed, and instantaneous, with the new bill eliciting a furious charge that the British Government was guilty of "smothering to death the infant institution of the Native press."134 Nor were the critics confined to the subcontinent. Even at Westminster, there were those who found the bill discriminatory and distasteful. Rising to his feet on the floor of Westminster, William Gladstone questioned the fairness of the controversial bill, charging, “"Do you wish it to be understood that the Vernacular Press is addressed to a public which is not intelligent; that those who read the English tongue are safe and to be trusted, while those who only read the Native tongue are not?"135 Given that the Irish Press Law served as the template for the Vernacular Press Act, it is rather surprising that the Government had learned nothing from its earlier experience with political fallout from such legislation. Not only was the Act even more wildly unpopular than the comparatively tame Irish Press Law, but also it proved logistically difficult to enforceand thus was of little help in acting as a deterrent to incendiary commentary. Indeed, the legislation acted as a spur to nationalist aspirations, uniting popular opinion against such repressive imperial policy. If the intent of the bill had been to quell an incipient uprising

\footnotetext{
${ }^{134}$ Guzerat Mitra, 24 March 1878.

135 "Motion for an Address," Hansard Parliamentary Debates, series 3, vol. 242, col. 54. Internet; available at http://hansard.millbanksystems.com/commons/1878/jul/23/motion-for-anaddress\#S3V0242P0_18780723_HOC_56; accessed on 22 May 2013.
} 
among the native press, the sobering reality was that the Government had only succeeded in strengthening the hand of its critics. Three futile and frustrating years later, the Government was forced to admit the folly of its ways, repealing the Act in even less time than it had taken to withdraw the Peace Preservation (Ireland) Act in 1870.

Whereas Tilak and Griffith and their colleagues ostensibly filled the same editorial roles, legislative measures adopted to monitor the native press in India were far more oppressive than those aimed at any newspapers in Ireland, despite the fact that the Irish press was demonstrably more nationalistic and rebellious. The Government of India would continue to regard the vernacular press as occupying a wholly separate category from the Anglo-Indian press - scrutinizing the former with greater suspicion, saddling them with more restrictions, and permitting them much less latitude than the AngloIndian press (or even the Irish nationalist press). The disparity was one which continually aroused the ire of journalists in the native press, who frequently complained that the Irish press was permitted without penalty to fill its papers with incendiary antiGovernment criticisms for which writers in the Indian native press would be charged with sedition.

More than circulation figures or editorials or Government correspondence, the British Empire's resort to repressive legislation is among the most telling indications of the impact of the nationalist press in Ireland and India. Regardless of the disparity in attitude toward the Indian and Irish press, the larger issue was the irreparable damage done to relations between the press and the Empire by both the Peace Preservation (Ireland) Act of 1870 and the Vernacular Press Act of 1878. Despite their repeal within a few short years, the Government's handling of criticism peeled away the veneer of 
liberalism and engendered a mutual distrust between the parties. That officials were so willing to abolish freedoms did, indeed, send a signal to those in the nationalist press that the time would come once again when the Government would seek to stifle all protest. By contrast with the tempestuous 1870 s, the following decade produced an era of relative peace, with the Government reverting to its pattern of monitoring, but not interfering with the nationalist press, while the press, itself, continued to push, but not cross over the boundaries of journalistic propriety. The seeming accord was, however, only a temporary rapprochement. The nationalist press was growing in stature and influence, with visionary new Irish and Indian editors stepping into the spotlight. These were men with a profound love of country, the zeal to change the world, and, most importantly, a fervent belief in the freedom of the press.

\section{The Tone of the Press}

For as much as the members of the Indian and Irish nationalist press shared a common mission, there were decided differences in the tone adopted by journalists to reach their respective audiences. The writing of Irish nationalist journalists tended to be punchy, emphatic, and idiomatic—leaving nothing open to interpretation—ensuring that the reader plainly understood the argument and that the British Government clearly got the message. The linguistic style of the press in India, however, was awash in metaphor and allusion, displaying a passion for both language and storytelling. Whereas the Irish journalist went straight for the British jugular, the argument of the Indian journalist was circuitous and often discursive - a result of Indian schooling in the English language. Commenting on the rich prose of native journalists, Australia's Launceston Examiner 
attributed the florid language — complete with imperfect English and "grotesquely mixed" metaphor-to national character. ${ }^{136}$ "The oriental is fond of parade, even in language," claimed the paper, "and the longer the words the more attractive, in his eyes and to his ears, is the style." ${ }^{\prime 137}$ The Irish editorials were visceral, appealing to emotion and desirous of obtaining a gut response. The Indian editorials—ornate and grandiloquent—seemed designed to appeal to the intellect.

Yet the language employed by the Indian nationalist press provoked profound concern among Government officials, who worried that those who heard the message were not equipped to react with calm equanimity. Nor was it only government officials who feared the increasing power and influence of the native press. In a lengthy polemic arguing for licensing of the native press, an anonymous author known only as TRUTH described the writings of the vernacular press as "malignant calumnies of lying agitators." Referring to "this huge body of crude and inflammable native opinion," TRUTH characterized the readership as "uninstructed, restless, ignorant, often fanatical," and, in his opinion, all too liable to swallow whole the screeds of editors "who are almost the avowed enemies of the Government." ${ }^{, 138}$ Accusing the native press of misusing its educative function, TRUTH avowed that the editors taught only hatred of the Government, rather than attempting to form "sound and loyal public opinion." ${ }^{, 139} \mathrm{He}$ described any good done by the press as "infinitesimal," while "the evil is enormous and

\footnotetext{
${ }^{136}$ Launceston Examiner, 7 February 1898.

${ }^{137}$ Ibid.

${ }^{138}$ TRUTH, "Why the Native Press Should Be Licensed," in Calcutta Review, (January 1900, Volume $110), 138$.

${ }^{139}$ Ibid.
} 
daily on the increase." ${ }^{140}$ Despite such underlying and often overt disdain for the native press, officials understood the backlash that full suppression or gagging would have provoked. Such measures were anathema not only to those in India, but also to those at home in the metropole, where freedom of the press was seen as sacrosanct.

\section{The Stage is Set}

As the nineteenth century drew to a close, there was the pervasive feeling that the press had an obligation to provide a mouthpiece for the voiceless, to air their grievances, and become their advocate. In effect, the newspapers granted agency to their readersproviding a public forum in which to confront the government with grievances and petition for redress. By the end of the nineteenth century, the nationalist press had assumed a preeminent place in Ireland and in India as the disseminator of critical information to the public at large. The newspaper was now an accepted social instrument capable of framing conversation and persuading public opinion. With increased literacy rates and easy availability of newspapers, it only remained for the nationalist press to seize on an issue that could hold the reading public in thrall, while editors murmured their honey-tongued anti-imperial rhetoric.

The British Empire proved surprisingly obliging in this regard, simultaneously lurching into a multi-national conflagration in Asia and stumbling into a martial morass in South Africa. Just as Britain had confronted the daunting prospect of the Second Afghan War, the Zulu War, and the First Boer War during the passage of the Vernacular Press Act in 1878, so now the country was about to become embroiled in a series of

\footnotetext{
${ }^{140}$ Ibid.
} 
conflicts that would distract it from the more mundane, but nonetheless essential, business of efficiently running the Empire. Whereas domestic issues might affect a select group of people or one geographical segment of the country, the outcome of the Boxer Rebellion and the Boer War would have a lasting impact on the Empire at large. The rising tide of a swift British victory would lift all of Britain's subjects, not only letting them bask in the reflected imperial glory, but also ensuring that the burden on the taxpayer would not be onerous, and that the Government would return to domestic concerns.

Conversely, should Britain become bogged down in a protracted war overseas, domestic issues would become marginalized, and the sole reason the Government would savor its Indian and Irish subjects would be to extract from them money, men, and natural resources. Should such a dismaying scenario transpire, there was always a chance the people of India and Ireland would begin to resent the imperial exploitation, bristle at the paternalistic attitude, and even question the basis for their allegiance. To Britons, however, there was little likelihood that the British Empire would struggle on the field of battle against a ragtag assembly of Chinese peasants and Boer farmers. Such an outcome was simply unthinkable. 


\section{"A Small Gust of Wind": The Boer War}

The news from South Africa was grave and unsettling. Ultimatums had been offered and rejected, war between the Boer Republic and Britain was imminent, and troops were massing on the frontier. From the outset, the impending battle seemed a decidedly unfair fight, conjuring up an indelible image of a ragtag band of rustic farmers, vastly outnumbered and armed only with antiquated weaponry and a zeal for independence. Desperate to protect their homeland, they bravely prepared to confront the formidable fighting forces of the British Empire. Against all odds, the plucky Boers miraculously delivered a series of stunning reverses that threatened to topple the imperial Goliath - in the process earning the Boers the admiration of the world and plunging the British into a morass of martial misery.

The fact that this widely-circulated version of the story coming out of South Africa was composed of equal parts breathless hyperbole, embroidered truth, and outright falsehood did not deter the Irish and Indian nationalist press from exploiting every facet of the Transvaal conflict to their advantage. Journalists scrutinized Britain's motives and rationale for the war, analyzed the conduct of its officers and troops, and pontificated on the impact of the conflict on Britain's prestige. Thus, the crisis in South Africa permitted the editors to use their columns not only to provide information about the progress of the war, but also to wax eloquent and often indignant on the moral compass of the British Empire, itself. Given the protracted nature of the conflict, Irish and Indian reporting of the Boer War provides compelling evidence of the constantly shifting attitudes toward Empire, and the myriad ways in which the press attempted to shape public opinion. 
An examination of the origins of what came to be known variously as the South African War, the Second Boer War, the Anglo-Boer War, and the Boer War of Independence provides insight into why the conflict aroused such deep passions in the Irish and Indian press. Britain had established its presence in South Africa as early as the Napoleonic Wars, when a British military expedition triumphed over Dutch forces at the Battle of Blaauwberg in the Cape Colony in 1806. After officially acquiring the colony in 1814, the British Government and its growing contingent of immigrants alienated the local Dutch settlers, particularly after the passage of the Emancipation Act of 1834 . Eager to escape British rule, the Boers embarked upon the Great Trek in 1836, which took them first to Natal, but ultimately to the interior of South Africa, where they established the Transvaal Republic in 1852 and the Orange Free State in 1854. Alive with expansionist zeal, the British Government annexed the Transvaal in 1877—a move that triggered the First Boer War, and ended in embarrassment for the British following a resounding victory for the Boers at the Battle of Majuba Hill. ${ }^{141}$

Although in the aftermath of the First Boer War the Boer Republics reestablished their independence, the 1866 discovery of diamonds at Kimberley sparked a marked increase in immigrants arriving in South Africa, eager to make their fortunes. It was the discovery of gold in Witwatersrand twenty years later, however, that proved to be the catalyst for an unprecedented surge in the foreign—and particularly British—population, as uitlanders flocked to the Transvaal. With only a scant supply of local workers, the

\footnotetext{
${ }^{141}$ As if to foreshadow the mistakes of the Second Boer War, the British forces-commanded by the astonishingly inept Major General Sir George Pomeroy Colley, British High Commissioner for South East Africa - made the mistake of underestimating their Boer opponent, led by Commandant General J.P. Joubert. The British fielded only twenty-two officers and 627 men, of whom 283 would be listed as casualties. Joubert would go on to command the Boer forces in the Second Boer War.
} 
Transvaal government was unable to mine fully its newfound resources and was therefore compelled to admit British fortune-hunters inside its borders, setting the stage for the heightened political tension of the 1890s. In September of 1899, Colonial Secretary Joseph Chamberlain demanded that the Boers extend full voting rights to the British uitlanders. Although the territory was ostensibly in the hands of the Boers, the British uitlanders were decidedly in the majority, a reality which President Kruger and his government understood would signal the end of Boer control of the Republic, if they acquiesced in the demand to extend suffrage. Picking up the gauntlet, Kruger responded to the British demand with his own ultimatum on 9 October 1899 , ordering the removal of all British troops from the borders of the Transvaal and the Orange Free State within forty-eight hours, or the Government would "with great regret be compelled to regard the action as a formal declaration of war." ${ }^{142}$ When Britain failed to comply, Kruger issued a declaration of war.

Given Britain's vaunted military reputation, a gross inequity in the size and nature of the Boer and British forces was expected, with the balance tilting overwhelmingly in Britain's favor. Yet, closer examination reveals that initial advantages in military preparedness were held not by the British, but by the Boers. Whereas the British would eventually deploy nearly 450,000 troops, until those reinforcements arrived-newly green - from Britain and other imperial postings, British forces were greatly

\footnotetext{
${ }^{142}$ Cited in Thomas Pakenham, The Boer War (New York: Random House, 1979), 104. Pakenham suggests that the failure in negotiations transpired as a result of Kruger mistakenly conflating the motives of Chamberlain and the designs of High Commissioner of South Africa, Sir Alfred Milner. Indeed, Milner later claimed, "I precipitated the crisis, which was inevitable, before it was too late." Cited in Pakenham, 116.
} 
outnumbered at the outset of the war. ${ }^{143}$ Although it was true that the Boer troops were primarily farmers, they were farmers who were remarkably comfortable on horseback and intimate with every inch of the interior's terrain.

Moreover, they were armed not with antiquated weaponry, but with the latest repeating Mauser rifles, newly acquired in bulk from Germany, as well as German $75 \mathrm{~mm}$ field guns, and the "Pom Pom," a converted Maxim machine gun capable of continuous fire. Aware that the Krupp factory was shipping field guns to the Boers, the nationalist Southern Star of West Cork excitedly informed its readers of the efficiency of the new weapons, stating, "The Krupp batteries are said to excel anything of the kind ever before supplied for foreign services." fighters," sharp shooters, and — in what would prove a somewhat prescient statement— "inclined to guerilla warfare."145 "For the first time in a good many years," pronounced the Tipperary-based Nenagh News, "British soldiers have had to face opponents who have some understanding of civilised warfare." ${ }^{" 146}$ Indeed, it was the British who struggled to field effective weaponry at the outset of the conflict. Beyond purely military considerations, the Boers also decidedly held the edge regarding such intangible factors as urgency and will. The Dutch settlers were fighting for their independence, and had the support of the entire countryside, which dutifully pledged allegiance to the cause.

\footnotetext{
${ }^{143}$ British General Sir George White fielded only 10,000 men for the war's opening skirmishes, whereas British reconnaissance estimated Boer forces at 15,000 to 20,000. Cited in Pakenham, 107-108. Pakenham puts the final British numbers at 365,693 imperial soldiers, together with an additional 82,742 colonial soldiers, facing a Boer force of 87,365. Ibid, 607.

${ }^{144}$ Southern Star, 21 October 1899.

${ }^{145}$ Ibid.

146 "The War in the Transvaal," Nenagh News, 28 October 1899.
} 
It was not merely Boer farmers and peasants who rallied to the cause. Both Ireland and the Indian subcontinent had long dealt with issues of British expansionism and imperialism, granting them what they believed were unique insights into events transpiring thousands of miles away in South Africa. Whereas both Indian and Irish nationalists evinced a marked interest in the progress of the war, the two camps sought to use the conflict in disparate ways. Given their natural antipathy to the British Empire, Irish nationalists - particularly Arthur Griffith and his fellow advanced-nationalistswere predisposed to support the Boer cause. Citing an indissoluble connection with the independence-loving Boers, Irish nationalist journalists lambasted British conduct of the war, protested recruitment of Irish soldiers, and cheered news of British reverses. By contrast, Indian nationalists initially espoused their loyalty and backed the British forces - desperately urging the British Army to send Indian troops into battle. Britain's refusal to deploy Indian soldiers, however, marked a turning point for Indian nationalists, who perceived in the refusal the ugly underpinnings of racial and religious bias. The presence of a sizeable community of several thousand Indian immigrants in South Africa, moreover, made the outcome of the war of vital interest to the subcontinent. If Ireland's criticism was proactive and born of a long and tempestuous history with Britain, India's critique was reactive and generated by the Empire's present conduct and condescension.

Armed with the motivating conviction that England's difficulty was Ireland's opportunity, the advanced-nationalist press in Ireland—including the United Irishman, Workers' Republic, and The Leader - seized upon what it considered the ideal moment to 
provoke the British, and immediately aligned itself with the Boer cause. ${ }^{147}$ The far from spontaneous decision of the moment was a political platform painstakingly erected over the course of two decades. In fact, the Irish affinity for the Boers actually had begun in 1877, during the era of annexation in the Transvaal, when a contingent of the Irish Parliamentary Party, led by Charles Stewart Parnell, had employed a series of increasingly obstructionist measures to disrupt proceedings at Westminster. ${ }^{148}$

The nationalist press instinctively understood that the war for Boer independence constituted a critical moment in forwarding Ireland's own nationalist agenda, and could best be served not only by emphasizing the similarities between Boer and Irish aspirations, but also by hammering home Britain's role in willfully thwarting those same hopes and desires. That the Irish adopted the Boers as comrades-in arms, united against Britain's expansionist zeal, constituted a significant moment in the history of the Empire. ${ }^{149}$ Irish nationalists - particularly those in the advanced-nationalist campaign, who would settle for nothing less than full independence for Ireland-identified with the Boers not only as fellow victims of imperial expansion, but also for their language movement, their folk tradition, and their religious ardor. ${ }^{150}$ Moreover, Boer nationalists, like their Irish counterparts, also harbored competing factions, including those who

\footnotetext{
${ }^{147}$ D.P. Moran founded the Dublin-based Leader to aggressively promote his agenda of an Irish Irelandreserved for those adhering to the Catholic religion and the Gaelic culture. As Moran founded the paper in 1900, commentary on the Boer War from The Leader will feature in a succeeding chapter.

${ }^{148}$ For a full recounting of the prolonged Irish protests in response to the Annexation Bill, see Donal McCracken's Forgotten Protest: Ireland and the Anglo-Boer War (Belfast: Ulster Historical Foundation, 2003), 3-9.

${ }^{149}$ Indeed, historian Donal P. McCracken characterizes the Irish pro-Boer movement as "the first effective example in modern times of solidarity of one colonially beleaguered people with another." Donal P. McCracken, Forgotten Protest: Ireland and the Anglo-Boer War (Belfast: Ulster Historical Foundation, 2003), Preface, xiii.

${ }^{150}$ McCracken, xvi.
} 
embraced non-violent methods and those who were increasingly ready, willing, and able to resort to physical force. ${ }^{151}$

Alive to the possibilities of exploiting the Boer War for the purposes of furthering Irish nationalism, the Irish advanced-nationalist press employed a three-pronged strategy to cover the crisis in the Transvaal: lauding the heroism of the Boers; reminding the reader of the links between the Boers and the Irish; and excoriating the British for their handling of the crisis. Thus, it was not enough to extol the bravery of the Boers and express solidarity; rather, the Irish nationalist press understood the necessity of demonizing the British. By undermining British capability and credibility in their coverage of the Boer War, Irish nationalist editors set out to convince their readers not only of the validity of the Irish cause, but also of the sweet possibility of bringing it to fruition.

Despite their implacable support of the Boer cause, the majority of the Irish press was convinced that the political animosity between the British and the Boers would not, in fact, result in war. "The British Government are not ready to go to war," pronounced the Freeman's Journal, the organ of the Irish Parliamentary Party, continuing, "The War Office has broken down hopelessly, and it will be nearly six weeks before the army corps so long spoken of can be landed in South Africa." 152 Once war actually erupted, however, the Irish nationalist engines steamed efficiently and effectively into action. The United Irishman, newly founded in 1899, announced the formation of the Irish Transvaal Committee and rigorously documented the progress of the Irish Transvaal Brigade,

\footnotetext{
${ }^{151}$ Ibid.

152،"London Correspondence,” Freeman's Journal, 7 October 1899.
} 
dutifully reporting minutes from each Johannesburg meeting. ${ }^{153}$ Composed of pro-Boer Irish soldiers from Ireland, South Africa, and even the United States, the Irish Transvaal Brigade was under the command of Major John McBride, and would constitute a powerful patriotic rallying point for Irish nationalists. ${ }^{154}$ Given the concerted push by the British army to enlist Irishmen, tales of the Irish Brigade functioned as the punchy Irish retort to British jingoism.

Outside of Dublin, attitudes among the members of the provincial press regarding the impending war were varied and somewhat unpredictable. In Tipperary, the Nenagh News lauded the much-circulated "Limerick Resolution," which proclaimed unwavering support for the Boers. The paper summarized the agenda of the recent Board of Guardians meeting, and reprinted details of the resolution, which attributed the lack of support for the "plucky Boer farmers" as "a great sign of National weakness and decay." "155 Yet, on the same day, the Kildare Observer decried what it referred to as the "misplaced sentiment" of those Irishmen throwing in their lot with the Boers. Reminding its readers that Irish soldiers stationed with British forces in the Transvaal, were, at that very moment, waiting to engage the Boers, the paper avowed, "there is not the remotest affinity, sympathy in County Kildare or in any other part of the country with the foreigners in the present crisis." 156 By contrast, the nationalist-leaning Southern Star in

\footnotetext{
${ }^{153}$ The United Irishman laid out in bare terms for its readers the stated goals of the Irish Transvaal Committee: "To express sympathy with the Free State and Transvaal Republics in their struggle against English aggression ... To discountenance the enlistment of young Irishmen in the British Army ... To present an Irish National Flag to the Irish Brigade in the Transvaal." 21 October 1899.

${ }^{154}$ In the aftermath of the Easter Rising in 1916, the British would execute John McBride for his part in the rebellion.

155 "Sympathy with the Boers," in Nenagh News, 7 October 1899.
} 
Cork woefully expressed its opinion that war was imminent, and that "in our next issue we shall have to chronicle bloody engagements in South Africa, all owing to the greed for new territory and lust of gold of the Britishers." ${ }^{, 157}$ At least at this juncture, there was nothing approaching unanimity among editors outside of Dublin.

Gleefully leading the Irish pro-Boer charge within Dublin was none other than Arthur Griffith, editor of the advanced-nationalist United Irishman. Having spent time in the Transvaal, Griffith not only counted many Boers among his friends, but also had long identified the Boers as fellow travelers in the struggle for independence against the British Empire. As a young man in South Africa, Griffith had alienated the readers of the weekly Courant in Middleburg by proclaiming in print, "the Boer and no one but the Boer owned the Transvaal." ${ }^{, 158}$ Such willful and deliberate antagonizing of his readership could bring only one result. "I eventually managed to kill the paper," recalled Griffith, a death which was anything but prolonged, given the fact that his backers immediately withdrew their support and the Courant shuttered after a run of only thirteen issues. ${ }^{159}$ By the time Griffith returned to Dublin and founded the United Irishman in 1899, the editor's devotion to the Boer cause was second only to his dedication to Irish nationalism. Indeed, this potent pair of political passions fused to produce what can only be characterized as an unremitting anti-British bias in the United Irishman. The prejudice towards all things British colored his editorials throughout the duration of the Transvaal conflict and long after. Thus, whereas the British press quite naturally sought to

156 “Misplaced Sympathy, Kildare Observer, 7 October 1899.

157 “The Transvaal War,” Southern Star, 7 October 1899.

${ }^{158}$ Cited in Padraic Colum, Arthur Griffith, (Dublin: Browne and Nolan Limited, 1959), 34.

${ }^{159}$ Ibid, 33-34. 
demonize the Boer - in an effort to stir up the requisite patriotic fervor - Griffith refused to be drawn in. Writing under one of his many pseudonyms, Griffith editorialized, "To lie about our enemies is, Britishly speaking, human — to systematically defame and slander them is Satanic." 160 He added waggishly, "There is nothing to equal the Englishman's ability for telling lies save the Irishman's capacity for swallowing them."161 In addition to denigrating all things British, advanced-nationalists Griffith, Connolly, and D.P. Moran waged a relentless war of words against Irish gullibility, reserving their deepest scorn for those Irish nationalists who believed that cooperation with the British would one day earn Home Rule for Ireland.

Griffith believed it was his responsibility to provide his countrymen with the antidote to what he perceived as poison dripping from the pens of the British press, as well as those in the Irish press who gullibly followed their lead. Moreover, the United Irishman decried what it saw as the influence of the "Jew Jingo Press" in shaping a more negative public opinion toward the Boers. "Throughout Europe and America, wherever the Jew capitalist has got a grip on the 'lying "Press of Civilisation," from Vienna to New York and further," charged the paper, "the pen of the Jew Scribe is uplifted to serve the cause of Sister England." ${ }^{\text {662 }}$ Referring to an article in the Austrian New Free Press that criticized what the United Irishman called the "gallant Boers," the publication described the Austrian paper as "the circumcised rag." ${ }^{, 163}$ Not an isolated case, Griffith's anti-

\footnotetext{
160 "Blackguarding the Boers," United Irishman, 14 October 1899.

${ }^{161}$ Ibid.

162،The Jew Press against the Transvaal," United Irishman, 14 October 1899.

${ }^{163}$ Ibid. Although Griffith biographer Brian Maye has attempted to refute the charges, there seems little doubt that Arthur Griffith was anti-Semitic, as were several of his advanced-nationalist colleagues. In
} 
Semitic screed was emblematic of racial theories circulating at the end of the nineteenth century. Social Darwinists advanced the belief that the white race was biologically superior-engaged in an eternal struggle for survival with the planet's inferior races. The theory encouraged the characterization of Jews as a base and malignant race, bent on domination. Despite, the fact, or, perhaps, because many in the British press had often characterized the Irish race as inferior, Griffith and many other Irish nationalists engaged in virulent anti-Semitism.

In addition to its weekly updates on the Irish Transvaal Committee —of which Griffith, himself, was a member — and the Irish Transvaal Brigade, the United Irishman most notably launched an aggressive anti-enlistment drive, warning its readers to shun the British recruiters and "Remember 98! Remember the Penal Laws! Remember the Famine!"164 As the year 1899 drew to a close, The United Irishman ramped up its antiBritish rhetoric, publishing for several consecutive weeks the Irish Transvaal Brigade's

addition to repeated references to the "Jew Jingo press" and the aforementioned characterization of an Austrian newspaper as a "circumcised rag," the United Irishman also referred to Johannesburg as Judasburg. Moreover, an article on the Dreyfus affair which appeared on 2 December 1899, described a Hyde Park protest as follows: "Some thirty thousand Jews and Jewesses, mostly of phenomenal ugliness and dirt, had come out of their East End dens at the summons of their Rabbis. If they hated France, it was also evident that they detested soap and water still more acutely." Maye's main defense of such articles is that the byline of "The Foreign Secretary" is not one specifically associated with Arthur Griffith. This dismisses the fact that Griffith referred to "Jew organs" while writing under his byline of "Ier," and that he was, moreover, editor of the United Irishman, and thus seemingly responsible for the content of the paper. Nor was Arthur Griffith the only Irish nationalist to scorn the Jews. In referring to an address on "Judaism and War" by the Chief Rabbi, the Freeman's Journal noted, "It is not, as the scoffer might imagine, an economic argument on the profits the race have so often derived from the squabbles of Christians." The paper summed up the position of British Judaism by stating, "Hence British Judaism blesses the British banner-and remains at home to reckon the gains," thus suggesting that British Jews aligned themselves with the British flag, but elected not to take up arms for its protection, choosing to remain on the home front, where they were sure to score a financial victory. Freeman's Journal, 11 November 1899.

${ }^{164}$ Ibid. The call to action urged readers to remember the Wolfe Tone uprising of 1798, the Penal Laws passed in the sixteenth and seventeenth centuries -which barred Catholics from owning land, voting, and a wealth of other activities - and the devastating Great Famine (1845-1852, responsible for the deaths of one million Irish men, women, and children.. 
proclamation: "Enlisting in the English Army is Treason to Ireland!"165 The insert reminded readers that "the Irishmen in England's service who are sent to South Africa will have to fight against Irish nationalists who have raised Ireland's flag in the Transvaal, and have formed an Irish Brigade to fight for the Boers against the oppressor of Ireland." ${ }^{166}$ Borrowing a patriotic piece of doggerel from the Irish Transvaal Committee, Griffith's paper greeted the New Year with this admonition to any who would enlist in the British army:

Go, to crush the just and brave Whose wrongs with wrath the world is filling! Go, to slay each brother-slave Or spurn the blood-stained Saxon Shilling! ${ }^{167}$

That any self-respecting Irishman would willingly enlist in the British cause was not a reality Griffith cared to acknowledge. The editor was relentless in his attack on those fellow countrymen who chose to fight for the British in the Transvaal, proclaiming, "The Irish Militiamen are being drugged, deceived, and kidnapped away to South Africa to fight the battles of the crumbling Empire." ${ }^{, 168}$ Clearly, Griffith viewed his newspaper as the launching pad for Irish nationalist aspirations, and the Boer War as the fuel necessary to propel his radical ideology toward its destination.

Griffith's paper was not the only Irish journal to print pro-Boer poems, songs, and ballads. Dublin's Evening Herald printed a decidedly anti-British set of lyrics, which included the lines:

\footnotetext{
165 "Enlisting in the English Army is Treason to Ireland," United Irishman, 16 December 1899.

${ }^{166}$ Ibid.

167 "Enlisting in the English Army is Treason to Ireland," United Irishman, 13 January 1900.

${ }^{168}$ Editorial, United Irishman, 20 January 1900.
} 
God save the Boers!

May their high battle-tide,

Still swelling far and wide,

Crush British greed and pride. ${ }^{169}$

Nor was the United Irishman alone in its unyielding support for Boer independence, or in seeing in the war a golden opportunity to sow the seeds of Irish nationalism among readers. The voice of Irish labor repeatedly weighed in on British conduct of the war. Blaming "an unscrupulous gang of capitalists" for what he predicted would be "one of the most iniquitous wars of the century," socialist James Connolly warned the readers of the Marxist Workers' Republic that Ireland was only a "negligible factor in the calculations of the Imperial Government," which thought nothing of shipping Irish troops to South Africa. ${ }^{170}$ Connolly suggested that if only Irish workers would unite, they could sap the British army of its strength in the Transvaal. ${ }^{171}$ One of Ireland's more vocal provincial papers, the nationalist Sligo Champion, intoned, "History does not record a more diabolical or more audacious scheme of plunder than that in which England is now engaged in South Africa."172 The paper added, "The sympathy of every just and upright man in the world will go forth to the brave Boers in their many struggles for the

\footnotetext{
${ }^{169}$ Evening Herald, 6 November 1899.

170 "The South African War I," Workers Republic, 19 August 1899. Connolly would later found the Irish Labour Party in 1912 and form the Irish Citizen Army in 1913. Uniting the ICA with the Irish Republican Brotherhood in 1916, Connolly assumed command of the Dublin Brigade, the premier force rebelling against the British in the Easter Rising. Arrested by British officials, Connolly was unable to stand for his execution, as a result of injuries sustained in the rebellion. He was tied to a chair and shot by a firing squad. The executions of Connolly and his fellow rebels - and the particularly disturbing nature of Connolly's execution - not only drew negative international response, but also were instrumental in increasing support for the cause of Irish independence.

${ }^{171}$ Ibid.

${ }^{172}$ Sligo Champion, 18 October 1899.
} 
preservation of their independence as a Nation." ${ }^{\text {173 }}$ The nationalist press harped on the twin themes of Boer nobility and imperial avarice, urging readers to emulate the former and repudiate the latter.

The Freeman's Journal insisted that Chamberlain's ultimatum to Kruger had been "modeled on the methods of the blackmailer," and alleged that the British Cabinet "want war to satisfy revenge and the greed for gold." ${ }^{, 174}$ The paper professed amazement at the British ability to rationalize the country's motives and conduct in the Transvaal, scoffing, "They are a wonderful people the English. There is a magnificent unconscious selfsufficiency about them which enables them to do the most unjust and the meanest things without the least loss of self-respect." ${ }^{175}$ The stinging rebuke coming from the normally moderate Freeman's Journal, the voice of the Irish Parliamentary Party, are indicative of the bitter toll the war was taking on relations between Britain and Ireland's nationalists.

A frequent contributor to the Freeman's Journal, agrarian Fenian firebrand and member of Parliament Michael Davitt submitted a lengthy anti-British polemic to the paper on the advent of the war, decreeing that the crisis in the Transvaal should not be referred to as Chamberlain's war or Rhodes's war or even the Rand Capitalist war, but was "more likely to live in people's memories as 'the liars' war.","176 Casting doubt on the veracity of war dispatches, which hailed English heroism and "the slaughter of Boers," Davitt catalogued the questionable coverage of events in the Transvaal. "There

\footnotetext{
${ }^{173}$ Ibid.

174 “London Correspondence," Freeman's Journal, 7 October 1899.

${ }^{175}$ Freeman's Journal, 11 November 1899.

176 “The Liars War,” Freeman's Journal, 29 November 1899.
} 
is, in fact, no parallel in history for the systematic, wholesale lying by which the Rhodes's gang in South Africa and their abettors in the British Jingo Press have tried to justify this most infamous war." ${ }^{177}$ Indeed, Michael Davitt, who had represented South Mayo in Westminster since 1895, resigned his seat on 26 October 1899, as a protest against the war. The bold move was characterized by the Irish People as one of the most stirring events in Ireland "since the death of Mr. Parnell." 178 Although the paper was undoubtedly engaging in a bit of patriotic hyperbole, the invoking of Charles Stewart Parnell's name was an indication of the seismic shock caused by Davitt's resignation from Parliament.

Certainly, it was no secret to the British Government that the Irish were predisposed to desire the defeat of the Empire. In truth, however, although the British perceived that Irish pro-Boer sentiment was ubiquitous, unanimity among Irish nationalists regarding the war was hard to find. Whereas Griffith and his fellow advanced-nationalists were certainly vocal in their opposition, some members of the Irish Parliamentary Party were loath to align themselves with such rampant and open Anglophobia. Inasmuch as they saw no problem with obstructing parliamentary proceedings in Westminster, they did not equate their disruption of government with the wholesale antagonism on display in the United Irishman, Freeman's Journal, and Workers' Republic. Indeed, there were many in the Irish Parliamentary Party who harbored the hope that if they supported the imperial cause in the war, British post-war gratitude would take the form of granting Ireland Home Rule. They feared that the

\footnotetext{
${ }^{177}$ Ibid.

${ }^{178}$ Irish People, 4 November 1899. Cited in McCracken, 49.
} 
tactics of the advanced-nationalists would jeopardize any hope of an autonomous Ireland in the near future.

John Redmond, the leader of the Irish Parliamentary Party—now reunited after nine years in the political wilderness - made clear the Irish nationalist position when he rose in Westminster to remind listeners of the words of the Englishman John Henry Newman, who stated that in Ireland, "the wrongs which England has inflicted are faithfully remembered, her name and fellowship are abominated, the news of her prosperity heard with disgust, the anticipation of her possible reverses nursed and cherished as the best of consolations." ${ }^{179}$ Redmond avowed, "We abhor this war; we call for its stoppage, and we declare our intention to do all that in us lies to maintain the independence of these two little Republics." ${ }^{180}$ Yet, Redmond staunchly repudiated any accusation that Ireland was supporting the Boer cause purely out of animus to Britain. "It is true that wherever the Empire is involved in a difficulty or complication which diminishes its great strength, a feeling of hope and satisfaction stirs through the veins of men of the Irish race both at home and abroad," asserted Redmond. ${ }^{181}$

\footnotetext{
179 “Seventh Day’s Debate," Hansard Parliamentary Debates, 7 February 1900, series 4, vol. 78, cc 832833. Internet; available at http://hansard.millbanksystems.com/commons/1900/feb/07/seventh-daysdebate\#S4V0078P0_19000207_HOC_16; accessed on 22 May 2013. Redmond also went on record as opposing the onerous taxes levied on the Irish in order to pay for the British war effort in the Transvaal. "From the Irish point of view, the voting of this money is intolerable," avowed Redmond. "It is an outrageous scandal, in my opinion, when a war is got up in South Africa of which the Irish people absolutely disapprove, that they should be called upon to pay a large proportion of the cost of the war." "Consolidated Fund (No.1) Bill. [Third Reading.]," Hansard Parliamentary Debates, 22 February 1900, series 4, vol. 79, cc 843-844. Internet; available at http://hansard.millbanksystems.com/commons/1900 /feb/22/consolidated-fund-no-1-bill-third-reading; accessed on 22 May 2013.

${ }^{180}$ Ibid.

${ }^{181}$ Ibid.
} 
The speaker, however, quickly provided what he characterized as the fundamental reason behind Ireland's position: Britain's flawed policy toward the Transvaal and what he perceived as an utter lack of merit regarding the conduct of the war. Moreover, Redmond assailed the role that Britain expected Ireland to play in the conflict, given that "an impoverished and over-taxed country is called upon to pay so heavy a proportion of the cost, and when so many thousands of Irish families, rich and poor alike, are called upon to pour forth the still more precious treasure of their children's blood."182 Redmond's rhetoric reminded the British Government that the Irish people continued to enlist in the British Army, in full expectation of a quid pro quo. The Irish offered their loyal service, but the price must be Home Rule at the war's end.

Despite Redmond's protestation, many in the Irish nationalist press did, indeed, appear to relish each new revelation of Britain's vulnerability—pouncing on evidence from the Transvaal of British strategic ineptitude and military incompetence. The unexpected Boer successes in the Battles of Stormberg, Magersfontein, and Colenso during the infamous "Black Week" in the first autumn of the war, not only took British generals by surprise, but also stunned the world. As for advanced-nationalist journalists following the war from Dublin, the fact that the supposedly outnumbered Boers-largely unschooled and untrained - were besting the vaunted military might of the British Empire was cause for celebration. ${ }^{183}$ Writing in the Workers Republic, James Connolly proclaimed, "Whether they ultimately win or lose, the Boers have pricked the bubble of

182 Ibid.

${ }^{183}$ Although the world press leapt on the unequal number of troops as evidence of a David versus Goliath confrontation, it was not until after the initial reverses in Mafeking, Ladysmith, and Kimberley that the British Government dramatically escalated the number of troops. 
England's fighting reputation. The world knows her weakness now." ${ }^{\text {"184 }}$ Alive with a vision of an Ireland unfettered from Britain, Connolly egged on his readers, urging: "Have at her, then everywhere and always and in every manner. And before the first decade of the coming century will close, you and I, if we survive, will be able to repeat to our children the tale of how this monstrous tyranny sank in dishonour and disaster." 185

Writing in the United Irishman under one of his favorite aliases, Arthur Griffith regaled his readers by reporting that British officials attributed losses at Ladysmith to a runaway mule that "stampeded" with the guns and ammunition. ${ }^{186}$ Michael Davitt also noted the occasion, offering "an expression of our approval of the conduct of some thousand of the British mules in the neighbourhood of Ladysmith in Natal," and suggesting that "some fitting testimonial will be made to the common sense of these intelligent animals in following the example of British soldiers in running into the camp of the victorious Boers." ${ }^{187}$ Griffith sang the praises of the Irish Brigade, which was present at Ladysmith, and noted gleefully that the entirety of the European press "save only the Jew organs," had acclaimed the British defeat. ${ }^{188}$ "The Christians of a hundred creeds everywhere exult at the staggering blow the splendid Dutchmen have dealt the Thief and Tyrant of the world," cheered Griffith, before providing a single caveat, "but she has still — praised by Yahweh! — the sympathy of the Jew." ${ }^{\text {"189 }}$ Griffith continued to

\footnotetext{
184 “The South African War II,” Workers Republic, 18 November 1899.

${ }^{185}$ Ibid.

186 "War Notes," United Irishman, 4 November 1899.

${ }^{187}$ The Times, 7 November 1899. Cited in McCracken, 48-49.

188 "War Notes," United Irishman, 4 November 1899.
} 
hold the Jews responsible for the conflict, setting them in opposition to the world's Christians, and singling them out as the only remaining ally of the British.

Indeed, as the war progressed, the United Irishman continued to indict the Jews as conspirators with the British Government, as well as finding them complicit in disseminating falsehoods about the Boer. "Stories of Boer atrocities" claimed the paper, "are daily invented by the infamous Jew-Jingo Press of England for the purpose of arousing murderous passions. ${ }^{, 190}$ Griffith perennially characterized Jews as the Other, a group he intimated was at odds not only with Irish religious values, but also with Irish morality. Moreover, his persistent pairing of the Jews with the British was undoubtedly an attempt to persuade his readership that the British character was equally as foreignand thus anathema - to the Irish. The fact that Griffith highlighted in print this supposed conspiracy between the British and the Jews is more evidence that the editor sought to use every facet of the war as ammunition for his cause.

The question of religion would play a prominent role in opinion swirling around the war, but the Irish and Indian press would approach the issue from significantly different vantage points. Whereas the Indian press assailed the violent behavior of a British nation that daily boasted of its Christian ideals, the Irish press were appalled at what they saw as the self-destructive nature of the conflict, with the Christians of Britain and the Christians of the Transvaal laying siege to each other. The Freeman's Journal cited the speech of Member of Parliament Leonard Courtney, who hoped that the world "might be spared the dreadful spectacle of a nation going to war with a kindred nation, a

\footnotetext{
${ }^{189}$ Ibid.

190 “The English Described by Themselves,” United Irishman, 2 December 1899.
} 
Christian nation." ${ }^{, 191}$ The United Irishman not only printed, but also re-printed two months later, a scorching letter from Father P.F. Kavanagh, who proclaimed that the time had come for "every Irishman, priest, and layman to raise his voice in strenuous and solemn protest against the participation of Irishmen in the colossal crimes being perpetrated by Britain against Human Right and Christian Creed in South Africa. ${ }^{, 192}$ In addition to decrying a war launched by one Christian nation at another, the Irish nationalist press seemingly sought to underscore the distinction between the Catholic morals of nationalist Ireland, and those of British Protestants.

As the war progressed, each week the Irish advanced-nationalist pressparticularly the always opinionated United Irishman and Workers' Republic - filled their columns with detailed accounts of troop movements, numbers of casualties, and predictions of upcoming engagements. Griffith's paper missed no opportunity to print yet another anti-British recruiting song, or list recent contributions to the Boer Wounded Fund, as well as donations to the newly founded Irish Ambulance Corps, created "to render aid to the wounded soldiers of the Irish Brigade and their Boer comrades." ${ }^{, 193}$ Indeed, Griffith never failed to provide an update on the exploits of the Irish Transvaal Brigade, and what the editors considered the Brigade's noble mission: “They have chosen the weak — the side of right and liberty—in the present war!, but primarily they have gone out to battle for Ireland." 194 As Griffith's sentiment makes clear, whereas the advanced-

\footnotetext{
191 “Mr. Courtney on the Tragedy,” Freeman's Journal, 13 October 1899.

192 "Father Kavanagh on the War," United Irishman, 23 December 1899. Father Kavanagh had already established his political bona fides by publishing in 1880 A Popular History of the Insurrection of 1798, which documented the rebellion by the United Irishmen and their leader, Wolfe Tone, against British rule.

${ }^{193}$ Editorial, United Irishman, 18 November 1899
} 
nationalist press was assiduously on the side of the Boers, its support was prompted by a larger mission: the independence of Ireland.

Submitting yet another lengthy letter to the usually more sober Freeman's

Journal, Michael Davitt chastised those Irishmen who sought to demonstrate their loyalty to the Empire, "in pledging other people's sacrifices to the war and its consequences, instead of offering their own." ${ }^{195}$ Davitt characterized the conflict as "this mean and ignoble war," in which "capitalist schemers" sent Irish troops to their death. ${ }^{196}$ Griffith and his Irish colleagues used the power of the press not only to report the news from South Africa, but also to affix a specific anti-British, anti-imperial, pro-Irish slant on war reportage. The Irish press — both nationalist and advanced-nationalist — variously characterized Britain as pirate, thief, and tyrant; the British soldier's actions were depicted as savage, brutish, and inhumane. These accusations, moreover, were leveled at the Empire not, as might be expected, after the British embarked on a scorched earth policy of burning farms, destroying resources, and interning women and children in the fall of 1900; rather, the Irish nationalist press was pre-disposed to believe the worst of its sworn enemy from the outset of the war.

The papers accused the British of avarice in their motives for the war, savagery in their conduct of the war, and deceit in their reporting of the war. Referring to rumors that the British had ordered their soldiers to gun down Boers, regardless of whether or not they attempted to surrender, the United Irishman wrote scathingly, "The prohibition of

\footnotetext{
${ }^{194}$ Editorial, United Irishman, 25 November 1899

195 “Loathsome 'Loyalty’ and the War,” Freeman's Journal, 4 December 1899.

${ }^{196}$ Ibid.
} 
telegraphic communication, the suppression of independent testimony, the rigid censorship of despatches are intelligible in the light of these horrible words." ${ }^{197}$ Apprised that Irish regiments were “once again in the front firing line," The Freeman's Journal expressed its fear that "another Irish holocaust has been paid at the shrine of British Jingoism." ${ }^{\prime 198}$ When Boer General Viljoen perished after the Battle of the Elands Valley, the United Irishman refused to be convinced that Viljoen was simply another casualty of war, as the British press had reported. Griffith insisted that the wounded general had been "despatched" by a British surgeon or officer while in custody. ${ }^{199}$ Griffith recalled Viljoen's horror when informed of the restriction imposed on the Irish by the Jubilee Coercion Act. ${ }^{200}$ "The story of England's treatment of her Irish political prisoners," stated the editor, "always made him sad to think that Jameson and his cutthroats had not been shot by the Boers, as they should have been."201 Thus, the United Irishman, the Freeman's Journal, and other members of the Irish nationalist press exploited every opportunity to castigate, abuse, and shame the British, and to inform their readers that much of Europe held the same opinion.

Even in these early phases of the war, the Irish nationalist press repeatedly limned their British foes in terms both vile and vindictive. "Scratch an Englishman and you find a savage," asserted the United Irishman, in a January article reprinting charges leveled by

\footnotetext{
197 “The English Described by Themselves," United Irishman, 2 December 1899.

198 “The War,” Freeman's Journal, 26 February 1900.

199 “Ben Viljoen,” United Irishman, 25 November 1899.

200 The Jubilee Coercion Act was the name given by its Irish foes to the Criminal Law and Procedure (Ireland) Act, 1887, which prescribed harsh penalties for a variety of nationalist tactics, including the use of the boycott. The bill's draconian measures proved even more unyielding than the earlier 1870 Peace Preservation (Ireland) Act.

201 “Ben Viljoen,” United Irishman, 25 November 1899.
} 
De Rand Post in South Africa. ${ }^{202}$ Griffith proceeded to catalogue the litany of war crimes allegedly perpetrated by British soldiers, including "murder under cover of the white flag, violation of the Red Cross, slaughter of the wounded, ill-treatment and assassination of prisoners, robbery of the dying." ${ }^{203}$ As the official organ of the Irish Parliamentary Party, the Freeman's Journal was not as vituperative in its accusations at this stage of the war. It was not, however, above stooping to questionable analysis of history, in order to press home its point about perfidious Albion. Asserting that the British treated African natives far more harshly than did the Boers, the paper avowed that the "Kaffirs" in Kimberley "are in a much worse position than the negroes ever were in the Southern States of America before the war., ${ }^{204}$ In a statement which must have left more knowing readers open-mouthed and incredulous, the Freeman's Journal proceeded to describe the ostensibly pastoral life of American slaves, stating, "The negroes had a pleasant life on the cotton plantations, and they were an elemental part of the estate and of the house that owned it." ${ }^{205}$ Regardless of this remarkably unenlightened vision of the American South, the allusion certainly painted the British in the least flattering of terms.

Not for the first time, the Irish press looked to India to make its points about the inequities and the iniquities of the British Empire. Upon hearing of the Indian famine that began in the fall of 1899 and would ultimately take the lives of nearly one million people, the United Irishman was quick to make the comparison with the Irish famine, proclaiming: "So there it is in a nutshell. The Indians perish as the Irish perished,

202 "In the Transvaal," United Irishman, 6 January 1900

${ }^{203}$ Ibid.

204 "The Boers and the Natives," Freeman's Journal, 17 March 1900.

${ }^{205}$ Ibid. 
because English Government stands between the nations and the rational utilisation of the natural resources of their own land." ${ }^{206}$ The paper connected the imperial dots for its readership, linking the famines with the struggle in the Transvaal, declaring, "That, too, would be the fate of the smiling farms of the South African Republics, if strong men in rightful arms were not there to shoot straight, and to shoot often." Ardent nationalist Maud Gonne — who would wed Major John McBride of the Transvaal Brigade at the conclusion of the war-offered her own assessment of the relationship between the Empire and its subjects, stating, "We in Ireland, like those in India, have let ourselves be hypnotized by England's pretended greatness, and have thus brought about our own real weakness. ${ }^{207}$ The message was clear: India and Ireland should no longer be servile; violence was the only response that would compel the British Government to change its course. Thus, the Irish advanced-nationalist press, once again, exploited the crisis in the Transvaal, in order to further the nationalist agenda, and mold reader opinion about the British Empire.

Contrary to what many in the Indian native press complained was a double standard employed by the British Government in its treatment of Indian and Irish journalists, it was not always the case that the Irish press benefited from British leniency. Ireland was in England's backyard, and the presence of government officials in Dublin Castle meant that the Irish press was always under surveillance. ${ }^{208}$ Anti-British rhetoric on Griffith's part compelled Dublin Castle to ratchet up its surveillance on the United

\footnotetext{
206 "Piracy in Africa and Famine in India," United Irishman, 2 January 1900.

207 “Signs of Hope,” United Irishman, 13 January 1900.

${ }^{208}$ Dublin Castle housed the headquarters of the Chief Secretary for Ireland, as well as the offices of essential British officials and bureaucrats charged with administering justice in Ireland.
} 
Irishman, which the government was convinced was publishing articles that were nothing short of "seditious and treasonable." ${ }^{209}$ Moreover, the fact that the majority of Ireland's newspapers required no translation made it fairly simple to discern if journalists were bordering on sedition with their pro-Boer output. Certainly, Arthur Griffith proved so outspoken on the subject of army recruitment and British conduct in the Transvaal that the office of the Chief Secretary for Ireland made a particular practice of acquiring advance copies of the United Irishman. Each issue was meticulously scrutinized, with examiners marking questionable passages before sending them on to the Chief Crown Solicitor to decide if the writing was sufficiently objectionable as to warrant taking action.

As the summer of 1900 approached, the knowledge that British forces were battling both Boers and Boxers excited nationalists in the Irish press. In London, the Evening Telegraph took note of the phenomenon, declaring caustically, "Thus it is ever with the Irish Nationalists. Whenever they find Britain or British soldiers and sailors in trouble, they rejoice." Offering an even more pointed analysis of what it viewed as the Irish nationalist philosophy, the paper continued, "They have no love for the Boers or the Boxers, but it is sufficient for them that these people war with England." ${ }^{210}$ Indeed, articles lambasting British policy in the Transvaal now vied for space in the United Irishman with those taking to task the Empire's actions in Peking. Outlining a blueprint for Irish independence, James Connolly informed the readers of the Workers Republic, "Now it only wants a native rising in India, and then would come our Irish

\footnotetext{
${ }^{209}$ Secret memorandum from Chief Secretary's Office, Police and Crime Division, CO 904/159, National Archives, Kew, London.

${ }^{210}$ Evening Telegraph, cited in United Irishman, 30 June 1900.
} 
opportunity."211 The author, however, had little faith that his countrymen would emulate the martial spirit of the Chinese and the South Africans, suggesting that the Irish would “rise up in our millions ... pass 'strong' resolutions, and then go home and pray that somebody else may beat the Sasanach." ${ }^{, 212}$ Connolly left his reader with an indelible slogan: "The Boers are invulnerable on kopjes, the Boxers are death on missionaries, but we are irresistible on "resolutions." ${ }^{213}$ While praising the Boers for their tactical use of the South African terrain and acknowledging the ferocity of the Chinese rebels, Connolly was clearly frustrated that his countrymen seemed to prefer pronouncements and posturing over substantive action.

Given this virulently anti-British, anti-imperial stance, it is not surprising that the British capture of Pretoria on 7 June 1900 elicited from the Irish press not a chorus of victory cheers, but a dissonant moan of discontent and a decidedly embittered grunt. By the summer of 1900, it seemed the Boer War would no longer afford choice opportunities to verbally engage the British foe. The Irish nationalist press, however, was not willing to let go of this meaty bone without a fight. The United Irishman described the British victors as "Imperialists, elegant, brilliant, and idle; courageous too; but not capable of undergoing the burden of a war," and reminded its readers that "in the last years England has been victorious only where she has had allies to fight with her of all colours." ${ }^{214}$ By contrast, the fallen Boers were "men with a firm faith of great power of resistance and

\footnotetext{
211 “A Great Opportunity,” Workers' Republic, 30 June 1900.

${ }^{212}$ Ibid. Sasanach is an Irish word for an English Saxon.

${ }^{213}$ Ibid.

214 “Foreign Notes," United Irishman, 2 June 1900.
} 
health, simple, calm, and trusting in their righteous cause."215 The paper was quick to mark the distinction between the combatants, noting "The first it is true can bring ten men into the field against one of the other, and their means are inexhaustible. But the others have right on their side, and have proved during the last six months that their strength of purpose is not diminished." ${ }^{216}$ For Griffith, Irish right was certain to triumph over British might, if only his countrymen would remain as steadfast as the Boers.

Although the Irish nationalist press initially expressed doubt that Britain would engage the Boers in battle, once the die was cast and Britain had committed its troops, editors wasted no time exploiting Britain's trials in the Transvaal. Viewing the war as a grasping move by a greedy imperial power, the papers pounced on the crisis as an unparalleled opportunity not only to foster Irish solidarity with the Boer cause, but alsoand more importantly — to denigrate all things British. The press did more than report the war. Arthur Griffith and his colleagues urged their readers to shun the British recruiting effort, shamed those countrymen who enlisted in the British cause, and raised funds to support John McBride's Irish Transvaal Brigade and the Irish Ambulance Corps. In addition to highlighting tales of British bungling and ineptitude, Irish nationalist editors headlined tales of British savagery, while simultaneously dismissing stories of Boer atrocities as the product of a Jewish press in league with the Government. The Irish advanced-nationalist press made sterling use of British failures abroad to chip away at Britain's imperial reputation, daily belittling the British Government. The non-stop barrage of anti-British rhetoric demonstrates that the Irish press was not only interested in

\footnotetext{
${ }^{215}$ Ibid.

${ }^{216}$ Ibid.
} 
offering fraternal support for the Boer effort in South Africa; rather, the journalists were keen to exploit the war as a means of furthering the Irish nationalist political agenda at home.

If Ireland's nationalist press remained remarkably consistent in its aggressively pro-Boer, anti-British rhetoric, early Indian nationalist press coverage of the conflict was notable for a more nuanced journalism. Beyond the immediate interest in determining the eventual victor of the war, and analyzing what it would mean for relations between Britain and the Transvaal, were the thornier and more complex questions of the impact of the war on British prestige and the consequences for the Empire, itself. The Boer War crystallized for many in the Indian native press not only the defects of the British Government, but also the serious problems inherent in imperial rule. These years witnessed a marked political shift by the native press, as it moved from gentle remonstrance with, to harsh rebuke of the British Government and the British Empire at large. By analyzing Britain's motivation for war, seeking to understand its refusal to deploy native troops, and, in particular, observing Britain's treatment of Boer women and children, the Indian press used the crisis in the Transvaal to unleash a full-throated outpouring of anti-imperial rhetoric. As such, the Boer War marked a decisive turning point in native loyalty and admiration for the Empire. Even a cursory reading of the Indian coverage of the Boer War reveals a growing discontent with the Government, and a profound disillusionment with the country's role in the Empire. Moreover, as would be the case with their coverage of the Boxer Rebellion, the distinct differences between the Irish nationalist press and the Indian nationalist press regarding the South African war brought home the prickly question of race in the Empire. 
Just as the Irish press had doubted Britain would go to war, initial news of the impending crisis aroused little concern among the native press in India, as confidence emanating from the British Government served to promote an air of inevitable victory. "The success of British arms in the Transvaal is certain," boasted the Bengal-based Manbhum, asking, "What nation of the world is not aware of the heroism and indomitable courage of the British?"217 British preparation for the conflict duly impressed the Samiran, which informed its readers, "The British have never displayed so much anxiety, have never made such vast preparations, have never acted with so much caution, have never so much discussed the question of fighting such an insignificant and half-civilized enemy as the Boers." ${ }^{218}$ The paper seemed to suggest that the fuss and furor over the war were at odds with the circumstances, leaving the impression that if the mighty British Empire was in such a worried state, then perhaps not all of the pertinent facts about the war had been shared with the Indian people.

Of all the provinces in India, Bengal had long constituted one of the most problematic for Britain, in terms of both politics and security-lending layers of complexity to its criticism in the press of the British Government. The Bengali soldiers in the Indian Army had been in the vanguard of those who rebelled against the British during the Indian Mutiny of 1857, and were still considered highly suspect more than four decades later. As such, Bengali recruits were excluded from participation in the British Army. Moreover, in the aftermath of the Mutiny, the British Government had instituted a doctrine of the "Martial Races," which sought to classify Indian ethnic groups

\footnotetext{
${ }^{217}$ Manbhum, 7 November 1899

218 Samiran, 8 November 1899.
} 
as either brave and fit for the rigors of war, or sedentary and non-martial. ${ }^{219}$ Griffith and his Irish colleagues clearly were not alone in their adoption of questionable racial theories. Britain's governance of India reflected its own brand of institutionalized racism - a practice that deeply dismayed and even offended its Indian subjects. Under the guise of cataloguing soldiers according to their active or sedentary lifestyle, officials cleverly managed to marginalize not only those, such as Bengalis, whose loyalty to the British Army appeared questionable, but also those of superior intellect. ${ }^{220}$ Regardless of the fact that Bengali soldiers had led the Mutiny, by the end of the nineteenth century the British had successfully imprinted on the public an image of the province as weak and unmanly, the home of the "effeminate Bengali babu," whose short stature and vegetarian diet stood in stark contrast to the sturdy manly meat-eaters of the Punjab.

Not surprisingly, the native press in Bengal, led by the Hitavadi and the Bangavasi - two organs that would come to earn the scorn of the India Office for their “inveterate hostility to government" - proved highly vocal in voicing disapproval of British conduct in the Transvaal. ${ }^{221}$ Whereas there was little doubt that Britain would emerge victorious in short order, these papers expressed concern about the British Government's actual motivation for the war. "The fighting strength of the English is

\footnotetext{
${ }^{219}$ Lieutenant-General Sir George MacMunn rather patiently and paternalistically explained the rationale for the doctrine, stating, "In India we speak of the martial races as a thing apart because the mass of the people have neither martial aptitude or physical courage." Lieutenant General Sir George MacMunn, The Martial Races of India (London: Sampson, Low, Marston and Company, Ltd., 1933), 2. Cited in Jeffrey Fingerhut, "Sahib and Sepoy: An Inquiry into the Relationship between the British Officers and Native Soldiers of the British Indian Army," in Military Affairs, Vol. 18, No. 1 (Jan., 1984), 16.

220 "The Martial Race theory had an elegant symmetry," notes military historian Jeffrey Fingerhut, adding, "Indians who were intelligent and educated were defined as cowards, while those defined as brave were uneducated and backward." Fingerhut, 16.

${ }^{221}$ Ikram Ahmed Butt, Lord Curzon and the Indian States, 1899-1905 (AuthorHouse, 2006), 60.
} 
unlimited, their wealth and resources are infinite, their collection of arms and ammunition is extraordinarily vast, and their troops are invincible," wrote the Hitavadi. ${ }^{222}$ "It is the proud consciousness of this fact," suggested the paper, "that leads the English to hold the world in contempt, to think that there is no one in this world who can be their fit opponent. ${ }^{223}$ The Hitavadi could not resist identifying what it conceived of as a troubling flaw in Britain's thinking, hinting that such pride was certain to precede a most unfortunate fall.

Together with most observers, the Indian native press expressed astonishment when the Boers immediately seized the upper hand and besieged the towns of Mafeking, Ladysmith, and Kimberley. "The English people, whose prowess and intelligence have established a world-wide empire, who leveled the pride of martial France to dust, who have always successfully stood in the way of Russia carrying out her warlike designs," commented the Decca Prakush, "are now being beaten at every step by a handful of Boers - by the inhabitants of such a small country as the Transvaal. ${ }^{224}$ The sense that Britain had dramatically and drastically underestimated the physical and moral strength of the Boers was prevalent throughout the coverage of the British setbacks in the Transvaal. Given that journalists had gone to great lengths to loyally laud British military might, they now sought an explanation for the unexpected turn of events. For many, the reverses were rooted in British pride, as the Madras-based Swadesamitran observed: "The folly of the British in having originally thought lightly of the Boers now

\footnotetext{
${ }^{222}$ Hitavadi, 10 November 1899.

${ }^{223}$ Ibid.

${ }^{224}$ Decca Prakush, 17 December 1899.
} 
becomes patent. ${ }^{.225}$ In Bengal, the always critical Hitivadi ruefully explained to its readers: "That the French are laughing in jubilation, that the Germans are indulging in ridicule, that the Dutch are shouting in joy, that the Russians are looking on with eyes beaming with delight and that the sound of heart-rending banter is coming from America - all this is the outcome of that excessive pride on the part of Great Britain." As did many nationalist journalists in India, the Hitavadi regarded such hubris as a dangerous weakness - a possibly fatal flaw preventing Britain from recognizing and acknowledging its tenuous position in the hierarchy of world powers.

Not all papers, however, were willing to attribute the losses to a fault on the part of the British. Instead, many in the native press were quick to credit the prowess of the Boers. "The Boers have displayed great heroism, cheered the Persian Hablul Mateen, "and President Kruger has done the work of a Bismarck." 226 The ardently nationalist Bangavasi opted to sing the praises of the Boer general who had managed to inflict such losses on the British forces: "Bravo! Joubert, old Boer General, bravo! ... A fly you have fought with fire. A hare, you have tormented the lion. A dwarf, you have, so to say, touched the moon with your hand. Bravo, General Joubert, bravo!"227 The Samiran hailed the Boers' "indomitable courage, unconquerable energy, and unparalleled heroism."228 The Hitavadi agreed, stating, "The oppression of the Indians in South Africa has led us to hate the Boers, still we feel constrained to praise their bravery with a

\footnotetext{
${ }^{225}$ Swadesamitran, 12 December 1899.

${ }^{226}$ Hablul Mateen, 5 February 1900.

${ }^{227}$ Bangavasi, 25 November 1899.

${ }^{228}$ Samiran, 8 November 1899.
} 
thousand tongues," while the Vartadarsh conceded, "The Boers are, in a way, our enemies; nevertheless, we cannot but admire their bravery, patriotism and love of independence." ${ }^{229}$ Whereas the Irish nationalist press immediately championed the Boers, merely because the Boers were waging war against their mutual British enemy, the Boers had to earn the praise of the loyal Indian nationalist press, by virtue of their martial achievements on the field of battle.

Regardless of their professed loyalty to the British Government, it seemed that members of the native press could not resist expressing their admiration for the Boers' ability to resist and overpower British forces. In the Punjab, the Paisa Akhbár extolled the Boers' mobility and marksmanship, as well as their "inexhaustible supply of remounts" and "intimate knowledge of the country," before conceding that it was a "foregone conclusion that in the long run the Boers will have to submit to the inevitable. ${ }^{, 230}$ Going even farther in its praise, the Sat Dharm Pracharák declared that the Boers" "great gallantry and steadfastness" had earned the country the right to remain independent.. ${ }^{231}$ As the war progressed and the Boers refused to succumb to British forces - even in the face of what was to become Britain's scorched earth policy toward the Transvaal — the native press would find itself even more torn between the combatants.

It was not surprising to the British that the Irish supported the Boers, given that the Irish nationalist philosophy was decidedly opportunistic and antagonistic. The native press in India, however, had frequently proclaimed its loyalty, avowing that the Boers

\footnotetext{
${ }^{229}$ Hitavadi, 10 November 1899; Vartadarsh, 31 March $1902 .$.

${ }^{230}$ Paisa Akhbár, 21 May 1900.

${ }^{231}$ Sat Dharm Pracharák, 15 June 1900.
} 
were their foes specifically because the Boers were the enemies of the British. The Bangavasi insisted, "The three hundred millions of loyal Indians are sincerely praying for British victory." ${ }^{, 232}$ As with the Irish nationalist press, however, Indian nationalist journalists made clear, however, that the loyalty was tendered in anticipation of a quid pro quo. "Indians are a loyal people," affirmed the Tripura Hitaishi, "and want to get the right of self-government, living as they do under British rule."233 The Sanjivani asserted that even a British defeat would not dampen Indian loyalty; rather, it would strengthen the bond: "The Indian will then really be a citizen of the British Empire, and will receive the glorious rights and privileges of British subjects." ${ }^{234}$ Under the guise of expressing its profound loyalty, the native press was actually seizing the opportunity to school its readership in the traditions of British Government, and, by extension, the inalienable rights to which the Indians, as subjects of Her Majesty, believed they were entitled.

Given these unabashed declarations of loyalty to the British Empire at the onset of the South African crisis, the ensuing pronouncements of admiration for the Boers, combined with accusations that Britain was waging an unjust war, marked a significant shift in the dynamic that existed between the Indian native press and the British Government. As readings in a number of papers make clear, this stage of the conflict witnessed the beginning of concern in the press about the impact of the reverses not only on the outcome of the war, but also on British prestige. The initial Boer victories were accompanied by a change of fortunes for Britain's military forces, and would ultimately

\footnotetext{
${ }^{232}$ Bangavasi, 6 January 1900.

${ }^{233}$ Tripura Hitaishi, 25 December 1899.

${ }^{234}$ Sanjivani, 18 January 1900.
} 
inflict irreversible damage on Britain's status among the European nations. Regardless of the fact that the Boer contingent was not, in reality, heavily outnumbered until British reinforcements arrived, the perception was that a cadre of peasant farmers had unexpectedly and altogether miraculously thrashed Europe's most formidable fighting machine. India's native press circulated this perception, exercising its power to shape public opinion toward the crisis in the Transvaal.

Indeed, the native press in India emphasized the impression that the reverses boded ill for Britain's standing amongst the European Powers. Recalling recent history, the Hablul Mateen predicted woefully, "If England is defeated in the war, she will fall not only in the estimation of the Boers, but also in the estimation of Europe, as Italy did after her defeat at the hands of the Abyssinians." ${ }^{, 235}$ The Hitavadi cautioned, "Our enemies are waiting for an opportunity. The reverses in the Transvaal War are sure to lower British prestige in the eye of the other European Powers. ${ }^{, 236}$ In the Punjab, the Paisa Akhbár of Lahore specifically fretted about the relationship between Germany and Britain, asserting that " 99 per cent of the residents of the Fatherland are heart-and-soul with the Boers, and that it is their earnest desire to ruin and humble England." ${ }^{237}$ The Charu Mihir was more forthright about the reasons for the deterioration of Britain's vaunted reputation —advising Britain to negotiate with the Boers at the earliest convenience: "British prestige will not suffer if such a brave nation as the Boers are allowed to enjoy their liberty," suggested the paper, adding, "but British prestige will

\footnotetext{
${ }^{235}$ Hablul Mateen, 25 December 1899.

${ }^{236}$ Hitavadi, 9 February 1900.

${ }^{237}$ Paisa Akhbár, 31 March 1900.
} 
greatly suffer if England is compelled to conclude a peace after reinforcements have failed to conquer the Boers. ${ }^{238}$ Unlike Irish nationalist journalists who repeatedly sought to demolish the reputation of the Empire, at this early juncture the majority of Indian nationalist journalists still prized their connection with the British.

The issue of how the native press in India was covering the British reverses in the Transvaal proved somewhat of an incendiary topic, given that the Anglo-Indian press openly accused the native press of savoring each British defeat. For their part, the AngloIndian papers rejected even the most tepid critique of Britain's conduct of the war, and, in fact, launched their own barrage of criticism at members of the vernacular press for what the papers characterized as acts of disloyalty in time of war. In the Punjab, the Taj-ulAkhbar of Rawalpindi responded to the charges by declaring that Indians had "never hesitated to lay down their lives in the service of the Government," while the Paisa Akhbár of Lahore that stated that Muhammadans throughout India "offered prayers to the Almighty for the victory of British arms in south Africa." ${ }^{, 239}$ In Bengal, the Mihir-oSudhakar also issued a staunch declaration of Muslim loyalty, declaring, "We are pained to hear of the loss of British life and money in the Transvaal War," adding, "The Mussalmans, who are the most loyal subjects of the English, consider British difficulty as their own difficulty."240 This avowal of loyalty to the Empire appeared to be a striking refutation of Ireland's vaunted policy of opportunism.

\footnotetext{
${ }^{238}$ Charu Mihir, 19 December 1899.

${ }^{239}$ Taj-ul-Akhbár, 16 December 1899; Paisa Akhbár (Lahore), 10 February 1900.

${ }^{240}$ Mihir-o-Sudhakar, 8 December 1899.
} 
Several native papers across India pointed out the stark difference between attitudes toward the war in Ireland and on the subcontinent. The Hablul Mateen in Calcutta claimed that Ireland's demonstrable sympathy for the Boers "is one of the chief causes of the determination of the Boers to fight against the British." ${ }^{241}$ Noting that "liberal contributions are being made to the War Fund in India" at the same time the Irish were enlisting financial support for the Boers, the Koh-i-Núr of Lahore insisted that if any native had "behaved like the Irish, his fellow countrymen would have killed him like a dog and torn him to pieces."242

Many in the Punjabi native press-including the Civil and Military News, Sialkot Paper, and Paisa Akhbar, did, indeed, urge their readership to contribute to the war fund; however, several papers expressed concern that the generous instinct was misplaced, given the ravages of the recent famine. The Akhbár-i- 'Am insisted that "charity should begin at home," while the Sada-i-Hind declared, "Those who neglect to subscribe towards the Famine Relief Fund and yet contribute towards the War Fund can only be regarded as anxious to show their loyalty." ${ }^{243}$ There was, even at this early point in the war, an understanding that from the British perspective, India's sufferings paled in comparison to the military setbacks in the Transvaal.

The Hitavadi used this knowledge to launch its own response to the criticisms of the Anglo-Indian press, claiming that the fate of India was inextricably wound up with the fate of the Empire: "For our peace as well as for our happiness, for our trade no less

\footnotetext{
${ }^{241}$ Hablul Mateen, 22 January 1900.

${ }^{242}$ Koh-i-Núr (Lahore), 9 January 1900.

${ }^{243}$ Akhbár-i- 'Am (Lahore), 9 December 1899; Sada-i-Hind (Lahore), 18 December 1899.
} 
than for our domestic economy, for the protection of our lives no less than for the protection of our property, we are entirely dependent upon the English."244 The paper then launched its own volley at the critics, demanding, "Will our Anglo-Indian contemporaries kindly explain to us how it can be possible for the Indians, under circumstances like these, to rejoice over the reverses of English arms?"245 The native press truly had nothing to gain from an imperial loss, given that they still held out hope that a victorious Britain would reward their loyalty. When the criticism of the vernacular press — and the Indian public, in general — did not desist, the Hitavadi leveled its own pointed accusation: "The Anglo-Indians . . . ought to know that in abusing the natives they are, in fact, abusing the Government. If the Indians be really dissatisfied with British rule, it must be to the discredit of the British Government."246 With this statement, Bengal's most outspoken paper confirmed that loyalty to the Empire was not synonymous with slavish admiration and obedience; Britain's rule of the subcontinent was not beyond reproach. The Hitavadi and other like-minded nationalist papers saw the conduct of the Boer War as a harbinger of what editors warned were alarming portents for India.

Seeking a more concrete explanation for the reverses in the Transvaal beyond that of British pride and overconfidence, the Hitavadi identified specific aspects of the fighting that would prove most onerous to British troops. "The English are fighting in a foreign country," explained the paper, "while the Boers have taken up arms to defend

\footnotetext{
${ }^{244}$ Hitavadi, 10 November 1899.

${ }^{245}$ Ibid.

${ }^{246}$ Hitavadi, 1 December 1899.
} 
their independence at all costs. ${ }^{, 247}$ The writer continued, listing the disadvantageous conditions under which the British troops labored: "The operations have to be conducted in unknown mountain passes, in a steep country covered with dense jungle and in a climate unsuited to Englishmen." ${ }^{248}$ That the terrain and climate were decidedly unfriendly to British troops raised one of the more pressing questions of the war-a question that would preoccupy the native press for the duration of the war and long after: Why did the British not deploy Indian troops in the struggle with the Boers?

The desire to fight for the British Empire constituted one of the most glaring differences between the Indian native press and the Irish nationalist press, and one which underscored the troubling issue of race in imperial relations. Whereas Arthur Griffith and his colleagues not only urged a boycott of British recruiters, but also were instrumental in forming the Irish Transvaal Brigade to fight alongside the Boers, the native press in India was dismayed that Britain continually overlooked the trained Sikhs and Gurkhas. "Would it not do to send the Gurkhas, who are so well trained in the art of English warfare?" inquired the Hitavadi. ${ }^{249}$ Answering its own question, the paper enumerated the myriad benefits of employing Indian troops: "There are thousands of native soldiers who are able to lay down their lives for any portion of the dominions of the QueenEmpress. If these men are sent to the Transvaal under the command of competent leaders, the trouble and hardship of soldiers unaccustomed to war will be considerably mitigated." ${ }^{250}$ The Charu Mihir chimed in, insisting, "The Sikhs and Gurkhas are always

${ }^{247}$ Hitavadi, 10 November 1899.

${ }^{248}$ Ibid.

${ }^{249}$ Ibid. 
spoken of in high terms. They would have felt happy if they had been allowed to show their valour in the war. ${ }^{, 251}$ It certainly did not escape the notice of Indian journalists that the government thought nothing of sending in ten thousand well-armed Indian troops to combat the Chinese army in Asia, whereas those same native troops were forbidden to fight the Boers in South Africa.

The Civil and Military News cited the Boer oppression of Indian immigrants in South Africa as a primary reason the British Government should permit natives "to go to the Transvaal and wreak vengeance on the Boers. ${ }^{, 252}$ Moreover, Britain's refusal to employ Indian troops was proving troubling not solely in the concrete terms of adaptability to terrain and climate, but regarding India's place within the Empire. "India is part and parcel of British dominion," proclaimed the Charu Mihir, asking, "Why, then, are not Indian soldiers allowed to maintain the glory of the Empire?"253 The Sanjivani in Calcutta ruefully answered the question: "But though the Boers are enemies, still they are white men, and our rulers have therefore refused to accept the services of Indian princes, being unwilling to employ black men in killing white men." 254 The paper continued its analysis, quick to point out the hypocrisy in the British war policy. "The Government has scruples in sending black men to the seat of war, but it has no such

\footnotetext{
${ }^{250}$ Ibid.

${ }^{251}$ Charu Mihir (Mymensingh), 26 December 1899.

${ }^{252}$ Civil and Military News, 8 November 1899.

${ }^{253}$ Ibid.

${ }^{254}$ Sanjivani, 20 January 1900 . This racial division was already familiar to the natives of India. Indian judges had previously been barred from presiding over criminal trials involving European defendants. The passage of the Ilbert Bill in 1884 had somewhat ameliorated the situation, by permitting Indian judges to try European defendants, but the bill also gave European defendants the right to demand that fellow Europeans comprise half of the jury.
} 
scruple in accepting black mens' horses and money for conducting the war., ${ }^{, 255}$ In this regard, the Sanjivani clearly felt the need to air the grievances of its readers. Their animals sent to the front, their meager income taxed for the war effort, but their offer of services rejected, the native population deeply resented British policy that could not look beyond prejudicial racial theories.

In the Punjab, home to the Sikhs and Gurkhas, the Patiála Akhbar lamented the fact that British soldiers had gone soft, and scoffed that "Tommy Atkins becomes raving mad if he cannot get his brandy and soda in the appointed time."256 The paper suggested replacing Tommy Atkins with Jack Sepoy, who would undoubtedly "soon make short work of the Boers." 257 The Wasir-i-Hind expressed the same sentiment, extolling the bravery of Jack Sepoy, "noted for his gallantry and intelligence all over the world," and insisting that the Boers "would never have been able to entrap him." 258 The omission proved even more rankling as it became increasingly evident that each new shipment of recruits was less well-equipped than the last in adapting to the harsh terrain. The critical Bangavasi delved deeper into the issue, cataloguing the countless conflicts in which Indian troops had assisted British forces in quelling disturbances across the breadth of the Empire: "The native troops of India have fought side by side and shoulder to shoulder with British troops in Tirah and Afghanistan, Burma, and China, and Egypt," boasted the paper, adding, "But now they have been compelled to sit idle and inactive. Is not this

\footnotetext{
255 Ibid.

${ }^{256}$ Patiála Akhbar, 24 November 1899.

257 Ibid.

${ }^{258}$ Wasir-i-Hind, 15 December 1899.
} 
likely to wound our heart?"259 One by one, the Bangavasi listed and dismissed the reasons put forth for bypassing India's native troops, rejecting out of hand the charges that the Indian troops were weak and insufficiently trained, that "their audacity and presumption will increase," should they succeed in routing the Boers, or that success would "embolden the native tribes of Africa." 260 Nationalist journalists saw beyond the unconvincing litany of excuses offered by the Empire for refusing native participation, and pressed their case repeatedly.

Challenging the wisdom of refusing to employ Sikhs and Gurkhas, the Bangavasi charged that Indian troops were "being treated with that indifference and suspicion with which a woman treats the children of a co-wife." ${ }^{261}$ If, indeed, the subcontinent was indeed the jewel in the crown, reasoned the press, why did British generals shun the use of native sepoys on the front lines against the Boers? The Bangavasi helpfully supplied the answer to its readers, explaining, "Here is the answer. The Transvaal war is a war between two white Christian nations, and, under the terms of the Berlin Treaty, native troops cannot be employed in a war between two white peoples." ${ }^{262}$ The paper took particular offense at the implication that Indians were uncivilized, and that the sight of native troops slaughtering "civilized" Dutch troops would be "an eyesore to the European nations." 263 The outspoken paper reminded its readers - including those in the British Government - that India could boast a long and esteemed civilization that produced

\footnotetext{
${ }^{259}$ Bangavasi, 13 January 1900.

${ }^{260}$ Ibid.

${ }^{261}$ Ibid.

${ }^{262}$ Ibid.

${ }^{263}$ Ibid.
} 
literary works that were "the wonder and admiration of the world.",264 "Complexion is not the standard of civilisation," declared the Bangavasi; adding that civilisation could only be found "in the excellence of the soul and the heart." 265 Demonstrating impressive unanimity, Indian nationalist journalists pressed home their point that the war in South Africa should be fought along political and not racial lines. ${ }^{266}$

Nor was it solely Indian journalists who questioned the Crown's refusal to employ Indian troops against the Boers. During Parliamentary debates over the cost of the Boer War, Colonel Victor Milward, Conservative Member of Parliament from Stratford-onAvon, argued that the Indian troops had proven their worth and that therefore "we should prove the solidarity of our Empire and its defences," by permitting the native soldiers to "hold the line of communication in South Africa." ${ }^{267}$ Notably, John Dillon- the MP from East Mayo and Redmond's lieutenant—countered this proposition by declaring, "I think it is a very wise thing to resolve that no coloured troops of any kind shall be employed."268 Given that Irish nationalists frequently sought to establish solidarity with India, this was an astonishing pronouncement. Dillon's stand makes it apparent that whereas there might be a kinship whenever political interests happened to coincide, there as yet remained a racial divide between the Irish and the Indians. Henry H. Howorth, former Member of Parliament for Salford South, strongly expressed his own dismay at

\footnotetext{
${ }^{264}$ Ibid.

${ }^{265}$ Ibid.

${ }^{266}$ Siálkot Paper, 16 January 1900.

267 “Army (Supplementary) Estimates, 1899-1900, Hansard Parliamentary Debates, House of Commons, 20 October 1899, series 4, vol. 77, cc 434-435. Internet; available at http://hansard.millbanksystems.com/ commons/1899/oct/20/army-supplementary-estimates-1899-1900; accessed on 22 May 2013.

${ }^{268}$ Ibid.
} 
the seemingly shortsighted British policy, extolling Indian troops as soldiers "who are burning and thirsting to be employed now, and to prove once more their devotion to their Empress and their loyalty to this country!" ${ }^{269}$ Enumerating the many advantages to be gained by the addition of Indian troops, Howorth identified not only their discipline and experience, but also the fact that they were already armed with British weaponry and could provide their own horses. "They never flinch from work or duty, their courage never flags," opined the author, before demanding, "Why should they be left out in the cold because their skins are a little darker, and as if they were savages?"270 Looking toward the day when a Russian invasion of the north-western frontier would compel the British Empire to call up its Indian troops, Howorth demanded to know how Russian soldiers differed from their Boer counterparts.

The refusal of the British Government to employ Indian troops became one of the salient issues for the growing nationalist movement in India, and the native press gratefully seized upon the topic to further its political agenda. By questioning why a country that repeatedly pledged its loyalty to the Empire was nonetheless considered suspect on the battlefield, the native press did more than underscore the hypocrisy inherent in the government's policy. Indian nationalist journalists shone a piercing light on the increasingly corrosive racist policies of the British Empire-hammering home the idea that despite protestations by the government, Indian subjects were, indeed, thought of as second-class citizens- - "barbarians" not fit to engage a "civilized" white enemy.

\footnotetext{
${ }^{269}$ Howard H. Howorth, "Our Indian Troops," in The Nineteenth Century: A Monthly Review. Jan 1900, Volume 47. Reprinted in British Periodicals, p. 36. Howorth served as a Member of Parliament for Salford South from 1886-1900.

${ }^{270}$ Ibid, 37.
} 
Moreover, by pointing out that the Irish press was vocal in its opposition to the war, yet Irishmen were still trusted with vital roles on the battle front, the Indian native press underscored the duality of imperial policy. The native press went to great pains to establish its contention that India was unique among imperial strongholds: "Indians are not Irishmen," avowed the Hitavadi. "They are famous for their loyalty. A kind word from the Government comforts us even under oppression and ill-treatment."271 As the Hitavadi was quick to point out, however, India's loyalty was proving a mixed blessing for its inhabitants. "India is, and always has been, loyal and peaceful," declared the paper," but added the caveat, "Under British rule, the Indian people have become much more peaceful, and their valour, military instinct, and self-help have almost disappeared, so that she is no longer in a position to do without England."272 The Hitavadi admitted ruefully that knowledge of India's placid compliance was a primary reason the British did not feel compelled to honor their responsibilities toward the subcontinent. Instead, observed the paper, "It is the Boers, the Irish, and the people of the English colonies who are the only peoples feared by England."273 The Hitavadi was among nationalist publications slowly coming to the realization that resistance and rebellion were the only currencies that would buy imperial favors.

Although the Irish press was quick to identify India as a fellow victim of British imperialism, the Indian native press was not yet disposed to claim affinity with the Irish. Instead, the native press repeatedly pointed to the example of the disaffected Irish in

\footnotetext{
${ }^{271}$ Hitavadi, 1 December 1899.

${ }^{272}$ Hitavadi, 17 August 1900.

${ }^{273}$ Ibid.
} 
order to underscore the loyalty of the Empire's Indian subjects. Despite the fact that Irish soldiers were fighting in the Transvaal in both the Boer and British armies, India was, in fact, more directly invested in the outcome of the conflict, for two more very specific reasons: the well-being of Indians in South Africa and the security of India's borders.

Whereas the Irish press certainly expressed its concern for Irish troops stationed in the Transvaal, those troops were not subject to the same sort of social, political, and economic persecution suffered by Indian immigrants living in the Transvaal. In part because of the correspondence of Mohandas K. Gandhi, who had returned from his studies in England to practice law in South Africa, it had become common knowledge that this large community of Indians had suffered ill-treatment at the hands of the Boers. The Bangavasi informed its readers that "Mr. Gandhi, the well-known Gujarati Barrister of Johannesburg, has written us a letter, complaining of Boer oppression of Indians in the Transvaal." ${ }^{274}$ As the Hitavadi explained, "The present war has been undertaken to enable English residents of the Transvaal to have a share in the government of that country. Indians have no such aspirations. All they want is security against maltreatment." ${ }^{275}$ If Britain were to emerge victorious, the native press theorized, surely the British Government would demand that living and working conditions for the Indian immigrants would be markedly improved, and the prejudice to which they were daily subjected would disappear.

Despite the fact that the Boer War elicited from the Indian native press many of the same criticisms - ranging from British shortsightedness and ineptitude, to the role of

\footnotetext{
${ }^{274}$ Bangavasi, 18 November 1899.

${ }^{275}$ Hitavadi. 10 November 1899.
} 
race in deploying combatants - there were, in fact, specific concerns about security that were linked directly to geographic location. If India had worried that the Boxer Rebellion was a distraction for Britain, the morass that was the Transvaal gave rise to concerted fears that the mother country no longer had a watchful eye on the subcontinent. Particularly among the members of the press in the north of India, this precipitated worries about the Russian bear menacing the frontiers. In Bengal, there was considerable concern about the subcontinent's vulnerability to a Russian invasion, should the Boers distract the British with prolonged fighting in the Transvaal. The press took it upon itself to chastise the British Government for becoming distracted by what many perceived as an unnecessary war. "If they ever invade India, cautioned the Hitavadi, "we shall be the first to suffer. That is why we feel it is necessary to say so much beforehand."276 "The English are busy in the Transvaal war," commented the Basumati, "and the huge Russian snake is about to make another advance in Asia." ${ }^{, 277}$ Casting a nervous eye at the borders and the build-up of Russian forces, the Sanjivani noted excitedly, "The Indian public have been thrown into great anxiety to learn that thirty thousand Russian soldiers have arrived close to the Afghan frontier, and that a Russian ambassador has already come to Kabul." 278 Thus, the papers in the north, while expressing concern about the conduct of the war, reserved much of their anxiety for the fact that the conflict was distracting Britain from the business of empire.

\footnotetext{
${ }^{276}$ Hitavadi, 10 November 1899.

${ }^{277}$ Basumati, 23 November 1899.

${ }^{278}$ Sanjivani, 1 February 1900.
} 
The capture of Pretoria by Lord Roberts on 5 June 1900 prompted an unprecedented outpouring of elation throughout Britain, with triumphant headlines in the British press and a spate of victory demonstrations in the streets of London. The expectation worldwide was that the Boers would cease all hostilities and surrender. Yet, if the British press was giddy and ecstatic, the Irish press was decidedly disgruntled and disconsolate. Their avowed enemy had escaped what had appeared to be an evertightening noose of defeat and dishonor. The native press in India, however, was more measured in its response, attempting to display its loyalty, while simultaneously expressing its concern over Britain's ostentatious celebration of victory. "Is it not a regret," queried the Hitavadi, "that the English, who are unrivalled in wealth and strength, should forget themselves in their rejoicings over the defeat of the insignificant Boers?"279 “All this leads us to suspect," concluded the paper, "that the British people are gradually losing all their splendid virtues. They who before allowed themselves to be moved, except by the most serious disaster, are now moved even by a small gust of wind." ${ }^{, 280}$ For nearly one year, from the first rumblings of war, through the initial British reverses, to the actual capture of Pretoria, the native press in India had, for the most part, remained loyal and unquestioning. Driven by what it perceived as a celebration that was out of all proportion to the event itself, however, many in the native press began to express profound dismay about the British Government, the British people, and the British character.

\footnotetext{
${ }^{279}$ Hitavadi, 24 May 1900.

280 Ibid.
} 
To the Irish nationalist press, the Boer War functioned as a handy club with which it could bludgeon its British political foes - criticizing the government, the military, and the Empire, itself. The plight of the Boers provided an object lesson to its readers on how a subject people could control its own destiny, even in the face of seemingly insurmountable odds. Yet, despite the involvement of Irish soldiers fighting both alongside and against British forces, the Boer War was, in fact, simply the most convenient weapon in the arsenal of the Irish advanced-nationalist press at that specific moment in time. The tone of its coverage did not alter, nor did the editorial content undergo any transformation as the war progressed. Indeed, the outcome of the war would not materially change the lives of those in Ireland, and Arthur Griffith and his colleagues were too canny to place all of their nationalist eggs in the Boer basket. After confessing surprise that the Boers had not defended Pretoria, Griffith surmised that the Boers had chosen to "save the men and guns for the second part of the war," and predicted that the conflict would ultimately end with the overthrow of British supremacy in South Africa. 281 "No one should prophesy unless he knows," cautioned Griffith, before adding slyly, "I prophesy because I know."282 The fact that Griffith's claim to omniscience was more a case of wishful thinking than convincing evidence was not enough to deter the editor from prematurely predicting the Empire's downfall.

The war, however, was far more personal to members of the native press in India, given the fact that the treatment of Indians residing in South Africa was at stake. Moreover, Britain's preoccupation with the Boers, as well as the Chinese Boxers, meant

\footnotetext{
281 "Respecting the War," United Irishman, 9 June 1900.

${ }^{282}$ Ibid.
} 
that India's frontiers were vulnerable and natural disasters such as the Indian famine were not addressed with the rapidity they warranted. Finally, Britain's decision to reject the services of Sikhs and Gurkhas in the Transvaal, while simultaneously deploying Indian troops in Peking, infused a level of palpable racial tension into relations between the Empire and its Indian subjects. Using the conduct of Britain in the Boer War as incontestable evidence, the native press brought home to its readers the sobering reality that despite the avowed loyalty of India, its subjects, and its troops, Indians would never achieve parity with their British or Irish counterparts. The outbreak of violence in China and the renewal of hostilities in the Boer War would find the Indian press questioning not merely whether Indian subjects would ever stand on equal footing with Britain, but whether a future in the Empire was something to be desired or spurned. 


\section{"Perdition to Pigtails": The Boxer Rebellion}

Peking was burning — schoolhouse and warehouse, church and chapel alike—set alight by Chinese Boxers enraged by the presence of European missionaries and western industrialists. Panic and confusion reigned, as terrified personnel swept through the streets, fleeing their legations in search of a safe haven that would offer even temporary refuge from the massacre that would surely follow. Barricaded at last within the walls of the British legation, for which sandbags offered the only fortification, were representatives from fourteen different nations - men, women, and children-including two thousand Chinese Christians. ${ }^{283}$ On the evening of 20 June 1900, the Boxer rebels, supported now by the forces of the Chinese imperial army, surrounded the legation, cutting off any means of escape or any hope of rescue. The siege had begun.

The final year of the nineteenth century produced the opening salvos in a trio of conflagrations that would embroil no fewer than nine imperial powers. The Boxer Rebellion (1899-1901), the Second Boer War (1899-1902), and the American War in the Philippines (1899-1902) sprawled over two continents and would begin the dramatic reshaping of the balance of power among the world's mightiest nations. America and the

${ }^{283}$ W.A.P. Martin, The Siege in Peking, China against the World (New York: F.H. Revell Company, 1900). Internet; available at http://www.shsu.edu/ his_ncp/bxr2.html; accessed on 14 March 2013. 
British Empire were the only two powers to have forces on the ground simultaneously in two different wars during this period. For its part, America's handling of its responsibilities in the Boxer Rebellion and the conflict in the Philippines served to enhance her stature as an emerging world power. Britain's role in the Asian crisis, however, combined with numerous setbacks in the protracted war in South Africa served to tarnish her prestige, deplete her man-power and materiel, and diminish her competitive standing internationally.

Indian and Irish nationalist journalists, for so long consumed by news emanating from South Africa, now found themselves transfixed by dramatic developments in China. The concurrent timing of the Boxer Rebellion and the Boer War provided Indian and Irish journalists with an enviable pair of targets on which to sharpen their rhetorical knives. British policy that could not be faulted in one conflict was invariably a fertile source of criticism in the other. Although nationalists in India and Ireland fiercely adhered to many of the same philosophical tenets, the Boxer Rebellion brought to the forefront several distinct divisions between those members of the Indian and Irish nationalist press. In addition to the significant role geography played in shaping attitudes, issues of race and religion sharply divided the journalists, dictating the disparate approaches they would take in covering the conflict in Asia. Already disturbed by discrimination toward Indian troops in the Boer War, the Indian nationalist press would skillfully use the Boxer Rebellion to highlight the hypocrisy of a British military policy that barred trained Indian soldiers from fighting against the Boers, yet readily deployed them in a battle against fellow Asians. Events in China precipitated a wave of pan-Asian sentiment among Indian nationalist journalists, who would use their practiced rhetoric to 
illuminate troubling examples of racial and religious bias - prompting their readers to reexamine the basis for their loyalty to a white and Christian empire. The Boxer Rebellion also emphasized the contrasting agendas pursued by the Indian and Irish nationalist press. Whereas editors on the subcontinent reluctantly criticized the conduct of the war, Irish nationalist—and particularly advanced-nationalist editors—deliberately sought damning evidence of British arrogance and ineptitude with which to convince their readers of the necessity of breaking free from Britain's imperial grasp. Thus, a side by side examination of press coverage of the Asian uprising and the crisis in South Africa illuminates the national interests of India and Ireland, and what they would portend for the Empire.

The end of China's isolationist policy—which had endured for centuriesushered in an era of uneasy relations between the Celestial Empire and foreign powers, including Britain, France, Germany, and Russia. Whereas the Chinese government had initially welcomed foreign powers, it rebuffed all attempts to permit the import of opium, which it had prohibited since 1729. The British, however, who oversaw the cultivation and production of opium in India, recognized that encouraging opium use in China would tip the balance of trade in Britain's favor. China's refusal to enter into trading agreements with the West would lead to its engagement in a series of misbegotten wars. ${ }^{284}$ Chinese forces succumbed to Britain in the First Opium War (1839-1842) and were bested by the combined forces of Britain, France, and the United States in the Second Opium War (1856-1860). The ensuing 1842 Treaty of Nanking and 1858

\footnotetext{
${ }^{284}$ Writing about the role of the British navy in settling conflicts with China, Niall Ferguson noted wryly, "It is one of the richer ironies of the Victorian value-system that the same navy that was deployed to abolish the slave trade was also active in expanding the narcotics trade." Niall Ferguson, Empire: How Britain Made the Modern World (London: Penguin Books, 1983), 166.
} 
Treaties of Tientsin did more than mark an end to hostilities and permit the import of opium. By granting special privileges to the foreigners, it created a powerful class, which was free to travel or trade at will, and remained virtually immune from Chinese law. "The Government of China having compelled the British merchants trading at Canton to deal exclusive with certain Chinese merchants," read the first clause of the Treaty of Nanking, "agrees to abolish that practice in future at all ports where British merchants may reside, and to permit them to carry on their mercantile transactions with whatever persons they please. ${ }^{285}$ The same treaty permitted British subjects to reside where they chose, "without molestation or restraint."286

By the end of the century, China had the unfortunate distinction of having been on the losing end of several more notable battles with foreign powers. It forfeited IndoChina to the French as a result of yet another ill-conceived conflict and lost control of Korea to Japan at the conclusion of the Sino-Japanese War (1894-95). Arthur Griffith's United Irishman ascribed China's loss to Japan in the Sino-Japanese conflict to Chinese war methods, which the paper characterized as "antiquated," rather than any "superiority of Japanese mettle and resources." ${ }^{287}$ Indeed, the paper characterized the Chinese intellect as "the equal, if not the superior, of the Frank," adding, "If he lacks enterprise and originality, it is because he is the slave of custom and the serf of prejudice. ${ }^{288}$ In Griffith's estimation, a reliance on ancestral guides was a sound domestic policy, but a

\footnotetext{
${ }^{285}$ Treaty of Nanking, 1842, Article I. Internet; UCLA International Institute; available at http://www.international.ucla.edu/article.asp?parentid=18421; accessed on 13 March 2013.

${ }^{286}$ Ibid, Article II.

${ }^{287}$ United Irishman, 30 June 1900.

${ }^{288}$ Ibid.
} 
disastrous course of action when engaged in relations with foreigners. Those relations worsened in 1897, when Germany effectively managed to parlay the deaths of two German missionaries into an excuse to wrest control of the Shantung peninsula. By the end of the century, as a result of these combined losses, the Chinese government had ceded control of large areas of its former territories to foreign powers. A country which had once jealously guarded its borders and repelled the intrusion of foreigners found itself playing host to contingents from Britain, France, Germany, Russia, AustriaHungary, Italy, Japan, and the United States - the so-called Eight-Nation Alliance— all of which established legations in Peking.

Released from onerous restrictions, foreigners expanded their reach geographically as well as ideologically, by aggressively challenging eastern thought and behavior. Religion, in particular, would prove to be the premier catalyst for the Boxer Rebellion, as the Chinese people, long accustomed to their own traditions and culture, bristled under the combined onslaught of missionary zeal and foreign ideas. The concerted efforts of the European powers to westernize the Chinese populace led to deep resentment among the Asians. By 1899, this anti-western, anti-foreign sentiment had crested, needing only further provocation — real or imagined — to swell into a tidal wave of animosity that would crash down with unrelenting force on the foreign legations.

The Society of Righteous and Harmonious Fists (I-ho-t'uan) — known as the Boxers because of their extraordinary acumen in martial arts - arose to assume the mantle of China's defense. Support for the Boxers arose, in part, as a result of a belief in their supernatural powers. The Boxers draped themselves in a cloak of supposed invincibility, ostensibly protected by potent magic that would ensure the defeat of their enemies and 
sweep the Boxers to triumph. In May 1898, the group, comprised largely of peasants in the north of China, began targeting Christians, posting public notices reading, "Protect our country, drive out foreigners, and kill Christians."289 The brutality escalated in the spring of 1900, as the Boxers embarked on a reign of terror, burning churches and slaughtering missionaries, as well as newly converted Chinese Christians. In Peking, on June 13, the summary execution by the German Minister, Clemens von Ketteler, of a young Boxer seemingly ignited the fuse, prompting an explosion of violence, in which thousands of Boxer warriors descended upon the walled city, burning Christian churches and murdering clerics and converts, alike.

One week later, on the afternoon of 20 June, with the city burning around them, nine hundred British, French, German, Russian, Japanese, and American diplomats and soldiers sought refuge in the Legation Quarter, and would remain under siege for the next fifty-five days. The Qing regime belatedly and perhaps shortsightedly aligned itself with the cause of the Boxers - the "brave I-ho-t'uan followers"-issuing an official Declaration of War on 21 June. $^{290}$ The accusations leveled at the foreign powers by the

\footnotetext{
${ }^{289}$ Cited in Jerome Ch'en, "The Nature and Characteristics of the Boxer Movement-A Morphological Study," in Bulletin of the School of Oriental and African Studies, University of London, Vol. 23, No. 2 (1960), 293. Ch'en argues that the aims and goals of the Boxers were constantly in flux, progressing through three distinct stages. Originally intended to eliminate foreigners, the Boxers only subsequently moved to support imperial Manchu rule, and finally espoused protection of the people. Ch'en asserts that the anti-foreign plank of the Boxer platform "remained predominant throughout." Ibid, 295. Writing in The Age of Empire, Eric Hobsbawm depicted the revolt as not only xenophobic, but also anti-modern, "directed against foreigners, Christianity, and machines. The Age of Empire 1875-1914 (Great Britain: Abacus Press, 1987), 282.

${ }^{290}$ Cited in Jerome Ch'en, "The Nature and Characteristics of the Boxer Movement-A Morphological Study," in Bulletin of the School of Oriental and African Studies, University of London, Vol. 23, No. 2 (1960), 293. Esherick asserts that the Declaration of War was not, indeed, a formal communication, "but just one of a flood of edicts coming from the court." However, he notes that only nine foreigners lost their lives before the declaration was issued, but in days after the declaration "with substantial official encouragement and complicity, a major bloodbath would begin." Indeed, Esherick argues, "The real violence - and especially the violence against foreigners - occurred only when the movement ceased to be
} 
Dowager Empress and her court attempted to provide a rationale for the wholesale slaughter of foreigners and Christians, charging: "The foreigners have been aggressive towards us, infringed upon our territorial integrity, trampled our people under their feet, and taken our property by force." ${ }^{291}$ The declaration, although specifically alluding to the plight of the Chinese, echoed and reflected the grievances of Britain's Indian subjects, thus securing for the Boxers some measure of pan-Asian sentiment.

With Peking in chaos, railway and telegraph lines destroyed by the Boxers, and few reporters on the ground, there was little chance that reliable accounts would make their way to the West. "Nobody can guess what is taking place beyond the veil which has descended over the scenes of rumored massacre and pillage," intoned the New York Times, adding "and the wildest conjectures are afloat." ${ }^{292}$ In the absence of verifiable news, the press leapt eagerly on any scrap of information, relating rumors of atrocities to their readers in a feverish frenzy of hyperbole that couched the conflict in terms of East versus West, heathen versus civilization. ${ }^{293}$ Given a lack of factual data concerning the siege, press organizations around the world elected to enhance and embellish the few available nuggets of news. The unreliability of official reports would be a recurring

under purely popular direction, when Manchu officials decided to use the movement for their own xenophobic ends."

${ }^{291}$ Ibid.

${ }^{292}$ New York Times, 20 June 1900.

${ }^{293}$ According to Robert B. Edgerton, evidence exists that these false reports of atrocities committed by the Boxers were deliberately disseminated by Li Hongzhang, who controlled the Chinese Telegraph service. Li's ostensible goal was to excite western opinion, exhort foreigners into exacting revenge, and ultimately bring down his own rivals in the Qing government. Robert B. Edgerton, Warriors of the Rising Sun: A History of the Japanese Military (Basic Books, 1999). Robert Hart, a key mediator in negotiating an end to the siege of Peking, was also deeply distrustful of Li, believing he had continually spread lies, "including the assertion that the Legations had arrived safely in Tianjin." Hans Van de Ven, "Robert Hart and Gustav Detring during the Boxer Rebellion,” in Modern Asian Studies, Vol. 40, No. 3 (Jul., 2006), 642. 
theme in foreign press coverage of Britain's imperial wars, particularly those in the more far-flung regions of the world. The perception of what was happening in China or in the Transvaal swiftly took precedence over reality—allowing Irish and Indian nationalist editors to shape, fashion, mold and even distort the story in such a manner as to further their own political agenda.

The role of geopolitical factors in contemporary analysis of the Boxer Rebellion was more apparent in the writings of Indian journalists than in that of their Irish brethren. That a strong element of Asian solidarity was present in the coverage by the native press in India was undeniable. The more outspoken members of the press did, indeed, read the struggle in terms of a geopolitical East versus West conflict, depicting the western European powers as the aggressor, heartlessly preying on the weak. According to many members of the native press, no less than the continent's political independence was at stake. The fiercely nationalist Hitavadi asserted that events boiled down to a simple question of "whether the black and yellow races of Asia will or will not be deprived of their liberty by the civilized and warlike nationals of Europe." 294 The paper concluded, "All the Asiatic nations, therefore, have their political interests involved in this war."295 Moreover, support for China in the Indian native press cut across ethnic and religious lines, most notably uniting Hindu and Muslim — each harboring anti-Christian and antiWestern sentiments. Thus, the Boxer Rebellion served as a catalyst in India for a unified anti-imperial front.

\footnotetext{
${ }^{294}$ Hitavadi, 27 July 1900.

${ }^{295}$ Ibid.
} 
Demonstrating their shared perspective, the Hindi Hindustan suggested that the European Powers "will crush the Boxers like locusts, and divide China among themselves," while the Bengali Hitavadi likened the European forces to "vultures flocking to the carcass. ${ }^{296}$ Continuing the theme of animalistic savagery, the Darussaltanat and Urdu Guide of Madras characterized China as a dying pig, whose liver was ruthlessly extracted by the British lion and whose entrails were being greedily consumed by the Russian bear. ${ }^{297}$ Whereas the image of an innocent lamb to slaughter was a regular feature in Indian editorials, the normally conservative Bangavasi in Calcutta, asserted, "opium-eating China" was not a helpless victim; rather, the populous empire was a sleeping giant newly awakened, poised to do battle with the powers of the West. ${ }^{298}$ The editorial was one of the first to reflect a growing pan-Asian sentiment, presenting the Boxer Rebellion in stark terms of an East versus West conflict.

The Persian language Rosnama-i-Mukaddas Hablul Mateen offered one of the more interesting analyses of the tendentious relationship between Asia and the European powers. The paper suggested there were three options regarding the manner in which Asiatic sovereigns should conduct business with Europe: exploit the rivalry among European nations in a quest for security; grant concessions in order to remain on friendly

\footnotetext{
${ }^{296}$ Hindustan, 20 June 1900; Hitavadi, 4 August 1900; The Kálidás also characterized the European Powers as carrion birds, stating, "These vultures, which have attacked the corpse of China, will not depart until they have devoured it." 30 June 1900. Indeed, Eric Hobsbawm envisioned the Boxer Rebellion in much the same way as the Indian press: "While the wolves were ready to form a pack against the prey, as they did when Britain, France, Russia, Italy, Germany, the USA and Japan joined to occupy and loot Peking in 1900 on the pretext of putting down the Boxer Rebellion, they could not agree on the division of the immense carcass." Moreover, Hobsbawm argued that the falling out of the western powers over the decaying body of the Chinese empire" was a direct contributor to the onset of the First World War. The Age of Empire (London: Abacus, 1994), 281.

${ }^{297}$ Darussaltanat and Urdu Guide, 27 May 1899.

${ }^{298}$ Bangavasi, 21 July 1900.
} 
terms; or remain locked in a hostile relationship. Condemning outright all three strategies, the paper reminded its readers: "Neither friendship nor enmity with the European Powers will be of any help to them. There is rivalry among the European Powers so long as their personal interests are concerned, but as against the poor Asiatics they are united."299 The writer warned, "They will not shed one another's blood or spend a farthing for our sake. ${ }^{, 300}$ Yet, after the siege had ended and China was boldly attempting to recover Manchuria, the Hitavadi noted pointedly, "The Chinese Empire has been saved from destruction by want of unity, and jealousy and distrust among the Western Powers." ${ }^{301}$ Indeed, the paper praised China for coming to an understanding that "in spite of the strength of the Western Powers their mutual jealousy has made them almost impotent."302 The writer suggested that the continuing envy and enmity among the European Powers would lead inevitably to a fresh round of global conflicts.

The Rosnama-i-Mukaddas Hablul Mateen saw in the events in China an object lesson for the Persian people. A substantial Persian population had been a fixture in India since the eighth century, with the first Persian-language paper making its appearance in 1822. Although largely assimilated into Hindu culture and customs, the Persian community was cognizant of the dangers of complacency, and repeatedly expressed concern not only for India, but also for the land from which their ancestors had emigrated. "One day Europe will take up arms against us," the paper warned. ${ }^{303}$ Laying

\footnotetext{
${ }^{299}$ Rosnama-i-Mukaddas Hablul Mateen, 1 October 1900.

${ }^{300}$ Ibid. 12 November 1900.

${ }^{301}$ Hitavadi, 4 April 1902.

${ }^{302}$ Ibid.
} 
out the rationale for self-preservation, the writer explained, "Persia being the only Islamic kingdom where the Muhammadan law is strictly enforced, the Persian akims ought to protect Islam. If Persia is conquered by Europe, Islam will die." ${ }^{304}$ Two weeks later, the paper cautioned, "Foolish indeed must be the nation which thinks that it can prosper by allowing foreigners to come into its own country." However, unlike the majority of the native press in India, the Rosnama-i-Mukaddas Hablul Mateen placed much of the responsibility for the failure of the Boxer Rebellion on the Chinese themselves, whom the paper accused of being "a cowardly nation. Five hundred millions though they are, they could not stand against fifty thousand European troops. This is all due to the fact that they are very idle and spend their time of peace in luxury." The paper concluded with the stern warning: "The Chinese affair is a good lesson for the people of Persia." ${ }^{305}$ Whereas the paper specifically advised the people of Persia to stiffen their collective spine and prepare to fight in defense of their country, concern about the enfeeblement of the Indian population would become a common refrain throughout the course of the conflicts in China and South Africa.

Conveniently ignoring Japan's role in subduing the Boxers, the Bangavasi focused on the efforts of Britain, Russia, Germany, and France to bring China to heel, drawing a historical comparison between the European alliance and the Crusaders. "History," proclaimed the paper, "does not record another instance of such union of Christian armies for the prosecution of a war against one nation. ${ }^{306}$ Acknowledging the

\footnotetext{
${ }^{303}$ Rosnama-i-Mukaddas Hablul Mateen, 29 October 1900.

${ }^{304}$ Ibid.

${ }^{305}$ Rosnama-i-Mukaddas Hablul Mateen, 19 November 1900.

${ }^{306}$ Bangavasi, 21 July 1900.
} 
religious underpinnings of the Rebellion, the Rangalaya drew a pointed distinction between Chinese martyrs and those in previous conflicts, recalling, "The great heart of Gladstone felt pity for the victims of the Bulgarian atrocities, but then, those victims were Christians. But how many Europeans have shed a tear for the poor Chinese, the fathers of civilization, when they are being killed like so many insects?"307 At the war's end, the Moslem Chronicle issued a harsh rebuke to the European powers for the "wholesale slaughter of Chinese, of brutal treatment of children, of outrages on women, and every conceivable form of brutality and licentiousness.",308 "And all this was done," charged the paper, "by men who adore Christ—-the Great Saviour who gave up his life for the love of men." 309 The propensity to point out the disparity between Christian words of peace preached by the European Powers and the violent deeds perpetrated by those same entities reflects the collective resentment harbored by Indians with a long experience of hearing their own faiths disparaged.

Whereas the suspicion that the western Christian powers were trying to subvert ancient religions resonated among much of the native press, many journalists sought to ascribe deeper political motives to the actions of Britain and her allies. The editor of the Sat Dharm Prachárak sounded an alarm concerning the agenda of the allied powers and feared that "evangelical Europe merely wishes to partition the heathen Chinese country." "310 "Indeed," scoffed the paper, "both America and Africa having already been

\footnotetext{
${ }^{307}$ Rangalaya, 3 May 1901.

${ }^{308}$ Moslem Chronicle, 18 May 1901

${ }^{309}$ Ibid. The Indian Mirror would later refer to the outcome of the Rebellion as a "dead moral loss, by which Christian peoples became converted into worse than beasts of prey." 30 May 1901

${ }^{310}$ Sat Dharm Prachárak, 6 July 1900.
} 
divided, what other field was left for the display of the Powers' Christian spirit of philanthropy?"311 Such commentary reveals Indian suspicions that the British Empire would use the mounting tensions between Hindus and Muslims as an excuse for partitioning India.

Citing the vigorous military preparations of the allied powers, The Wakil also suspected partition was in the offing, and characterized as disingenuous all European denials to that effect, while the Siálkot Paper urged Great Britain to prevent any partition, "as this would have the effect of lowering her prestige and injuring her trade in Asia. ${ }^{312}$ The Jámi-ul-Ulúm provided a caustic rationale for the partition, suggesting that the European Powers, "supposing China to be a good tit-bit, opened their mouths to swallow it; but as none could be allowed to eat it up singly, they agreed to partition it among themselves. ${ }^{, 313}$ In a more pointed commentary, the paper sarcastically ascribed a holy motive to the actions of the "pious Christian Powers," hinting that perhaps they mistook the Celestial Empire for the Heavenly Kingdom promised by Christ. ${ }^{314}$

As the above accusation makes clear, the Indian press did not attribute the Boxer Rebellion merely to a desire for geopolitical hegemony; rather, they strongly detected both racial and particularly religious motives in the actions of the West, with China being consumed by "Christian poison." 315 The issue of Christian proselytizing would return at

\footnotetext{
${ }^{311}$ Ibid.

312 Wakíl, 15 September 1900; Siálkot Paper, 1 October 1900.

313 Jámi-ul-Ulúm, 14 July 1900.

${ }^{314}$ Ibid.

${ }^{315}$ Hitavadi, 4 August 1900.
} 
conflict's end, with the Moslem Chronicle suggesting that if Christian missionaries were permitted to roam China at will, then the door should certainly be open to "Muhammedans trying to extend their faith also." ${ }^{\text {"16 }}$ Regarding the methods employed by Christian Europeans in their alleged crusade to dominate Asia, the Hitavadi not only identified the Bible, but also the brandy bottle and the bayonet as "three well known means of spreading knowledge and civilization in uncivilized countries." ${ }^{317}$ Thus, the provision of opium, which the paper termed "death and worse than death" to a Chinaman, was the first step in the eventual subjugation of the Chinese people, with the revenueproducing trade "enforced at the cannon's mouth.",318 These shared perceptions of how the West had sought to vanquish the independent spirit of the Chinese people resonated with Indian journalists, further solidifying their anti-imperialist stance.

If opium was the thin edge of the imperial wedge, then the presence of Christian missionaries provided the leverage to crack open the door to the Chinese empire. The refrain was echoed across all five provinces of India. In the eyes of the Indian press, the permanent settlement of missionaries in China was destined to provoke disturbances among the Chinese populace, which would escalate into violence and killings. Indeed, the Bengalee, edited by ardent nationalist Surendranath Banerjea, held European missionaries directly responsible for the Boxer Rebellion. "Real and fancied outrages on European missionaries have been used by almost every European power as efficient

\footnotetext{
${ }^{316}$ Moslem Chronicle, 23 March 1901. This the was not the first time the subject of Muslims in China had arisen. Six months earlier, the Rosnama-i-Mukaddas Hablul Mateen had suggested that the Chinese Mussalmans - "numbering nearly a hundred million"- should exploit the debacle "to raise the standard of rebellion against the Chinese government." 26 November 1900.

${ }^{317}$ Hitavadi, 27 July 1900.

${ }^{318}$ Ibid.
} 
handles to screw from the Chinese money and territory," charged the paper, while the Rosnama-i-Mukaddas Hablul Mateen sardonically cheered: "Bravo Christian missionaries! You are well versed in the art of carrying on political intrigues." 319 Toward the war's end, the Vakil remarked, "it is a crying shame that the Christian Missionaries, who are never tired of posing as the champions of outraged humanity, should have joined the soldiers in looting the Chinese. ${ }^{320}$ In the wake of the defeat of the Boxers, there was, indeed, an epidemic of looting — in which every occupying nation took part — with civilians, soldiers, and even missionaries descending on the city to scoop up their share of Chinese antiquities.

Offering an idea which they ascribed to Lord Curzon, the Vrittanta Chintamani indicted Christian missionaries as the source of all anti-foreign feeling in China: "Their high living, their large families, their contempt for the Chinese and their religion, their mixing freely with women, and their employing large numbers of women, mostly single, in mission work, - these are all disliked by the Chinaman."321 Although conceding that the Boxer cause was "misdirected" and doomed to failure, the paper lauded the rebels' motives as both "patriotic" and "unimpeachable.",322 The Madras paper was not alone in this description of the rebels. In Bombay, the Kál,- the publication of radical journalist Shivram Mahadev Paranjape_-also invested the Boxers with patriotic impulses,

\footnotetext{
319 Bengalee, 29 August 1901; Rosnama-i-Mukaddas Hablul Mateen, 1 October 1900.

${ }^{320}$ Vakill, 25 March 1901.

${ }^{321}$ Vrittanta Chintamani, 11 July 1900.

${ }^{322}$ Ibid. In addition to assigning blame to the missionaries, the native press sought other causes for the outbreak of the Boxer Rebellion. The Kerala Sanchari (22 August 1900) attributed the rebellion to "discourteous and cruel treatment of the Chinese by the European powers," while the Vrittanta Patrika of 21 June floated the theory that the Boer escapees from the Transvaal, or Boer sympathizers, had schemed to cause the political uproar.
} 
"however differently it may be characterized by selfish Europeans." extremist of Indian nationalists, Paranjape determined to portray both the Boxers and the Boers as lovers of independence, driven to violence by a desire to defend their countries. The implied message was that Indians who professed a love for their country could prove their patriotism only by openly resisting imperial domination.

Not for the first time, the native press also questioned the veracity of western reporting regarding this latest imperial conflict. The Prabhat scoffed at the recently dispelled rumors that Chinese warriors had not only killed the men, but also raped and then massacred the women, as well as their children. Reflecting the Hindu philosophy, the paper proceeded to advance the theory that even if the Chinese had committed atrocities, of equal importance was how the Europeans were treating the Chinese-details which seemed absent from western coverage of the Rebellion. Moreover, the Prabhat attempted to provide a rationale for the Chinese massacre of their own women, stating, "They believed that their chastity would not be safe in the hands of the Europeans. So they put them to death. If this is barbarity, what is heroism?"324 Whereas Indian readers perhaps had little reason to fear that the British would rape their wives, their households had been subjected to intrusive searches during the recent plague epidemic, prompting them to identify with the Chinese determination to protect their women from humiliation.

Inasmuch as many in the native press chose to reject rumors of Chinese atrocities and elected to believe the worst of the European powers, the motive was more complex than at first might appear. "We are not weeping for China," explained the Rosndmá-i-

\footnotetext{
${ }^{323}$ Kál, 29 March 1901.

${ }^{324}$ Prabhat, 22 August 1900.
} 
Mukaddas Habdul Mateen, "and we sympathize with this Celestial Empire only because it forms a part of the East, the portion of the world to which we belong. We are weeping for ourselves. ${ }^{2325}$ The Indian Mirror, however, noting that a British general was lying on his deathbed, held out a measure of hope for moral redress, asking, "When will these Powers learn to recognize and fear the law of Karma?"326 The paper returned repeatedly to the idea of karmic retribution. Long after the end of the Rebellion, as more details of atrocities emerged, the paper stated fervently, "Such acts must demand God's vengeance some day." 327 There were many who feared that the vision of Europe carving up China would soon be repeated in India. Given the unlikelihood of mounting sufficient physical resistance to such an incursion, perhaps karmic retribution could stop the imperial powers before they sat down to dine off the subcontinent.

The Pan-Asian sentiment which infused much of the reporting often hampered the ability of Indian journalists to maintain objectivity. The same Indian papers that were dismissive of reports of atrocities committed by the Boxers reprinted lurid tales of atrocities allegedly committed by the European powers. The Swadesamitran expressed little surprise at the behavior of the French and German soldiers, whom they termed "illiterate and irresponsible," because it had become common knowledge that "the Great German Emperor himself has ordered his soldiers to show no mercy to the Chinese." ${ }^{328}$

\footnotetext{
${ }^{325}$ Rosnamá-i-Mukaddas Habdul Mateen, 15 September 1900.

${ }^{326}$ Indian Mirror, 4 January 1901.

${ }^{327}$ Indian Mirror, 30 April 1901.

${ }^{328}$ Swadesamitran, 17 September 1900. In a speech addressed to German troops on 27 July 1900, Kaiser Wilhelm urged his troops to emulate the Huns, instructing, "Should you encounter the enemy, he will be defeated! No quarter will be given! Prisoners will not be taken!" Cited in German History Documents.
} 
The Phoenix also expressed particular horror at the behavior of the German troops, stating that the cruelties practiced by the other European powers "pale into nothingness when placed beside the heartless, atrocious and diabolical butcheries perpetrated by the German troops on inoffensive men and women in China." ${ }^{, 329}$ In the estimation of the editor of the Sat Dharm Parchárak: "European civilization has been weighed and found wanting. ${ }^{, 330}$ Long accustomed to hearing Asian civilizations denigrated and dismissed by European conquerors, Indian nationalists now seized the opportunity to identify the moral failings of Britain and its fellow European powers. This criticism would both heighten and narrow its focus to Britain with the renewal of hostilities in the Boer War. Britain was not without defenders in the native press, however, with the Lokopakari insisting that British generosity was at all times on display and that no British soldiers took part in the ill-treatment of the Chinese. ${ }^{331}$ The Rahbár also praised the behavior of the British troops for acting "comparatively very humanely." 332 Paranjape's Kál, while crediting British soldiers for refraining from committing atrocities in China, was — not surprisingly—unwilling to absolve British troops "for reprehensible conduct toward the Boers in South Africa. ${ }^{\text {} 333}$ The same paper assailed the Chinese people for seemingly being in a celebratory mood while attending the execution of their Boxer

\footnotetext{
Internet. Available at http://germanhistorydocs.ghi-dc.org/sub_document.cfm? document_id=755; accessed on 22 May 2013.

${ }^{329}$ Phoenix, 18 September 1901.

${ }^{330}$ Sat Dharm Prachárak, 20 December 1901.

${ }^{331}$ Lokopakari, 8 March 1901.

${ }^{332}$ Rahbár, 7 September 1901.

${ }^{333}$ Kál, 8 February 1901.
} 
leaders. "Such men as derive pleasure from witnessing the death of their leaders are fit for slavery and deserve being trodden underfoot by foreigners; they are utterly incapable of appreciating the high motives which inspired the actions of the Boxers." ${ }^{334}$ The paper reserved its praise for those who fought to the death for a noble cause, excoriating those who so quickly turned their backs on their leaders, in an effort to curry favor with their conquerors. Although the article made reference to events in China, the implication was that readers should stand steadfast in support of nationalists fighting for the rights of the Empire's Indian subjects.

Several voices among the Indian press were insistent that the European press had deliberately exaggerated the gravity of the crisis in China, in order to provide a rationale for further escalation. "In our opinion," stated the Rosndmá-i-Mukaddas Habdul Mateen, "the object of all that is being said about the seriousness of the Rebellion in China and the fighting resources of the Chinese army, is to justify the aggressiveness of the European powers in China.. ${ }^{, 35}$ In the estimation of the writer, Europe had only been waiting for a pretext to conquer "the fertile empire." 336 Now that the world had been made aware of Chinese transgressions, the Europeans "will not come back from China till they have conquered and divided it among themselves." ${ }^{, 337}$ The paper left the fate of the Chinese people in no doubt: "They will become accustomed to the disgraceful life of a slave."338

\footnotetext{
${ }^{334}$ Kál, 22 March 1901.

${ }^{335}$ Rosndmá-i-Mukaddas Habdul Mateen, 1 September, 1900.

${ }^{336}$ Ibid, 15 September 1900.

${ }^{337}$ Ibid.

${ }^{338}$ Ibid.
} 
Already, many in the nationalist press had begun to despair that Indians had become woefully accustomed to their status as British subjects and had lost the will to regain their freedom. The Rosndmá-i-Mukaddas Habdul Mateen's use of the imagery of slavery, in order to rouse the Indian reader from this stupor of acceptance, was a tactic also employed by Irish advanced-nationalist journalists, to invigorate their Irish readership and rally them to the cause of independence.

Unlike the war in South Africa, in which Indian troops were forbidden to fight white Boer soldiers, the British Government saw no problem in employing Sikhs and Gurkhas to combat the Boxers in Asia. Indeed, following the fifty-five day siege in Peking, the Sikhs and Gurkhas comprised part of the eight-nation rescue mission sent to relieve the beleaguered foreign diplomats and soldiers, and were the first foreign troops to enter the newly liberated Legation Quarter. As the Boer War progressed, and British troops became increasingly taxed by the guerilla tactics of the Boers, the native press in India would become increasingly vocal about this duality of policy. Despite the litany of reasons the Empire provided for refusing to deploy Indian troops in South Africa, their quick decision to send troops to China only emphasized the already glaring role of race in military policy. Not only did the doctrine of martial races divide Indian castes into those presumed to be more courageous and hardy, but also Britain's agreement with the European Powers at the Berlin Conference barred troops of color from fighting white troops. There was, moreover, the question of why the Empire was slow to appoint Indian officers. The Imperial Cadet Corps was not founded until 1901 and no Indian would be 
admitted to the military academy at Sandhurst until $1919 .{ }^{339}$ The debate over whether Indians were racially suited for command posts was as much about the specter of white troops objecting to an Indian leader, as it was about the character of native cadets. ${ }^{340}$ Tellingly, the only applicants admitted into the Imperial Cadet Corps were the sons of native Princes or those belonging to the martial races. The Indianization of the British Army thus proceeded in fits and starts until the founding of the Indian Military Academy in 1932.

India was not the only dominion concerned over which colonial troops should be deployed in Britain's imperial wars - and what remuneration they would receive. In Australia, debate swirled around whether the Boxer Rebellion constituted such a serious imperial conflict that the involvement of colonial troops was even essential. ${ }^{341}$ Those in the Australian government who opposed deploying that country's troops in China pointed to the fact that Australian troops were already fighting for the Empire in South Africa, "where Indians could not be used." 342 Moreover, given the fact that the British government could pay Indian troops fighting in China less money than other colonials, why would the Empire want to send Australian troops, whom they would have to pay

\footnotetext{
${ }^{339}$ For more on the travails of the Imperial Cadet Corps, see Chandar S. Sundaram, "Treated with Scant Attention": The Imperial Cadet Corps, Indian Nobles, and Anglo-Indian Policy," in Journal of Military History, 77 (January 2013), 41-70.

${ }^{340}$ Ibid, 48.

${ }^{341}$.According to historian Richard H. Wilde, whereas there was "great unanimity of feeling about the South African war" in Australia, officials were concerned that war against China was never officially declared. Thus, it appeared to be more of an imperial crisis than a "real war" in which the fate of the British Empire was truly at stake. In order to persuade Australians of the need to participate in the Boxer Rebellions, "Chinese barbarities were denounced, and the need to fight for Christianity and civilization underlined." Richard H. Wilde, "The Boxer Affair and Australian Responsibility for Imperial Defense," in Pacific Historical Review, Vol., 26, No. 1 (Feb, 1957), 57-58.

${ }^{342}$ Ibid.
} 
more? Thus, Britain's decisions as to where it would deploy Indian troops impacted opinion and policy not only in India, but also throughout the Empire.

Yet, press coverage of Indian troops deployed in the Boxer Rebellion seemed less concerned with questioning British policy in South Africa than in underlining the glorious opportunities the Asian conflict offered native troops. Unlike the crisis in the Transvaal, the Boxer Rebellion offered a chance to prove Indian loyalty, courage, and talent. Indeed, given the 20,000 troops sent to China by Japan — which did not occasion any outcry from the native press about Asians fighting Asians- the Public Gazette argued for the swift deployment of even more Indian troops, urging the British to grant an opportunity "to our hardy sepoys of showing their bravery on the battlefield." Specifically, the editor urged the government to reserve Sikh soldiers for the frontier wars and to deploy Muhammadans for the war in China. The idea that Muhammadans should no longer be sent to the frontiers stemmed from the fact that the frontiers were home to many Muslims. Therefore, "although the Muhammadan soldiers did not refuse to fight their co-religionists, still they could not fight to their hearts' content."344 Notably, the British Empire classified Sikhs and Mohammedans as ranking among the finest of India's martial races. Given Russia's repeated glances toward India, it was essential to man the borders with those considered physically and temperamentally suited to engage the enemy on behalf of the British Army. Indeed, with the exception of the Gurkhas, Dogras, and selected Hindustanis and Pathans, General Roberts—-then Commander-in-Chief, India — had declared, "there are no Native soldiers in our service whom we could venture

${ }^{343}$ Public Gazette, 24 June 1900.

${ }^{344}$ Ibid. 
with safety to place in the field against the Russians. ${ }^{.345}$ This seeming reliance on the doctrine of martial races to determine fitness in the field was a constant irritant to Indian nationalists who sought unity based on common aspirations for India, rather than division based on questionable racial theory.

Beyond the issue of the deployment of Indian troops, the native press identified a more compelling concern for the people of India. There were many who lamented the fact that the prolonged war in South Africa was preoccupying Britain to an alarming extent—exhausting its military capabilities, tarnishing its prestige, and, most especially distracting it from the business of Empire. ${ }^{346}$ Neglect, and (worse) exploitation, of Indian resources was a common theme. The accusation extended to the course of the Boxer Rebellion, during which the British Government ordered India to supply fodder for British horses and other animals. Commented the Khulna with suitable alarm: "If India is made to supply the Chinese expeditionary force with fodder for three months, there will not remain in India a single head of cattle living." 347 The timing was particularly unfortunate and telling, as India was suffering yet another one of her devastating famines, during which millions of cattle died of starvation.

Among the members of the native press, there was also concern over the disrespectful manner in which they perceived the British were treating China, an ancient empire. Certainly, this was a long-standing complaint regarding the British handling of

\footnotetext{
${ }^{345}$ Cited in Heather Streets, The Military, Race and Masculinity in British Imperial Culture, 1857-1914 (Manchester: Manchester University Press, 2004), 98.

${ }^{346}$ At the end of the crisis in the Transvaal, the Power and Guardian not only expressed dismay that the British "troubles" permitted the German empire to expand, but also suggested that the British interests in the Boxer Rebellion were another victim of the Boer War, 13 January 1901.

${ }^{347}$ Khulna, 12 July 1900.
} 
India, with Bal Gangadhar Tilak and his colleagues constantly reminding the reader that the Indian civilization pre-dated that of Britain by several centuries. Without a doubt, the despoiling of the graves of Manchu emperors, together with the robbing of antiquities"in order that the relics may enhance the beauty of the British Museum"- touched a nerve in many Indian observers. ${ }^{348}$ Since the arrival of the East India Company, British explorers, adventurers and collectors had been making their fortunes and their reputations by amassing India's antiquities, which frequently ended their journey in the exhibition cases of British museums. ${ }^{349}$ The Oudh Times offered even more poignant commentary on the topic, opining, "It is a sorrowful and humiliating sight to witness Christian and professedly civilized and young nations like the Germans, the French, and the British engaged in an attempt to portion out among themselves an old Empire, inhabited by a venerable and inoffensive people like the Chinese." ${ }^{350}$ The paper was even more distressed that the European Powers engaged in the conquest so soon after the Hague Peace Conference, and accused the allied powers with eschewing any attempt at arbitration in favor of charging into a war. ${ }^{351}$

It did not escape the notice of some in the Indian press that the other European powers on the ground in China were attempting to force Britain's withdrawal from the arena. "But the British people," stated the Puduvaimitran, "fearing that the honour and

\footnotetext{
${ }^{348}$ The Prativasi, 3 December 1900. The paper further lamented, "England no longer possesses a poet like Byron, or Englishmen could not, after thus desecrating and dishonouring the graves of ancestors ... show their faces before civilized nations; for the fire of righteous indignation kindled by his muse would have surely consumed every English heart."

${ }^{349}$ For an in-depth look at British and French imperial acquisition, see Maya Jasanoff, Edge of Empire: Conquest and Collecting in the East 1750-1850. (London: Fourth Estate, 2005), 404.

${ }^{350}$ Oudh Times, 27 April 1901.

${ }^{351}$ Ibid.
} 
glory due to their empire will be impaired if they do so, are resolved to maintain their ground in that country at any cost." ${ }^{, 352}$ Although reporting that the British government had dispatched 10,000 troops from India, the paper noted that the other foreign powers, particularly France and Russia, remained idle, hoping that a British defeat would lead to a hasty departure. The writer commented, "Everything is topsy-turvy in China."353 As the war progressed, the Puduvaimitran continued to inform its readers of Britain's isolation from the other allied powers - a condition which the paper claimed "forbodes unknown troubles to her!"354 "At the conflict's end, the paper lamented, "Thus all they have gained in South Africa has been more than counterbalanced by the loss they have sustained in China.”355 The Puduvaimitran's message was clear: whereas all of the other European powers had benefited from the outcome of the Rebellion, only the British had lost both power and prestige in China.

The resolution of the Boxer Rebellion evinced mixed emotions from those in the Indian press. Whereas the Jyoti exclaimed, "Any good news regarding China fills the mind of every Asiatic with joy," there was apprehension about the continued European presence on the continent. ${ }^{356}$ The Bangavasi summed up the cause of the anxiety, quipping. "Saying one thing and intending another is a wonderful resource of European politics." 357 The Kál was among those who deemed "unfair and exorbitant" the cost of

\footnotetext{
${ }^{352}$ Puduvaimitran, 20 October 1900.

353 Ibid.

354 Puduvaimitran, 17 November 1900.

${ }^{355}$ Puduvaimitran, 9 March 1901.

356 Jyoti, 28 November 1901.
} 
war reparations demanded by the European Powers, and warned that "tranquility so purchased" would not be long-lasting. ${ }^{358}$ Of particular concern were the intentions of Russia, whose Cossacks had ruthlessly mown down Chinese resisters and violated the Chinese women. Lamented the paper, "The fearful way in which the Czar's vow of peace was fulfilled produced a paralysing effect on the hearts of all Asiatics."359 With the constant rumbling about a possible invasion of India by Russia, fears for the safety of Indian resisters and Indian women were palpable. The prospect of Russians swarming over the border also fueled discussions of whether native troops would be allowed to face them in combat, given the proscription of native troops engaging white troops in battle.

The role of the Indian troops throughout the Boxer Rebellion continued to be a subject of much discourse at the conclusion of the conflict. The Lokopakari expressed pride in the performance of the Indian troops, who had earned a "very good name" during their deployment in China. ${ }^{360}$ However, the Phoenix was clearly disturbed by the fact that any mention of Indian troops was omitted from the list of those recognized for their service during the Rebellion. "They fought side by side with their white comrades-inarms, shared the same dangers, underwent the same privations, and endured the same hardships," the paper remonstrated. ${ }^{361}$ "But while the British soldier gets all the praises and rewards, the Indian sepoy, who gave as good an account of himself, gets nothing

\footnotetext{
357 Bangavasi, 14 December 1901.

${ }^{358}$ Kál. 10 May 1901.

359 Ibid.

${ }^{360}$ Lokopakari, 8 March 1901.

${ }^{361}$ Phoenix, 25 September 1901.
} 
beyond the blows he received in the course of the war." ${ }^{362}$ This oversight was particularly galling in light of the fact that the Sikhs and Gurkhas were the first to enter Peking at the conclusion of the siege.

Given its proximity to the subcontinent and the litany of grievances with which India could readily identify, the Boxer Rebellion held special interest for the Indian nationalist press. Like the Boxers, they resented western attitudes toward the religions of the East, and bristled at the ubiquitous presence of Christian missionaries. There was, as well, an inherent respect for a fellow Asian civilization of such antiquity. The issue of race, however, was paramount, with the Empire deploying Indian troops to fight fellow Asians in China, yet barring them from joining the British Army in South Africa to engage the white, Christian Boers. With the Boer War and the critical days of the Boxer Rebellion coinciding, the Indian nationalist press took pains to point out to readers the glaring disparity in imperial policy and attitudes. Although the Boxer Rebellion was not accorded as many columns as the Boer War in the Indian press, the coverage it did receive was frequent, extensive, and pointed in its critique of Western attitudes and actions. Yet, for all their cavils and complaints, Indian journalists remained courteous in tone and unfailingly loyal to the Empire.

By contrast, the Boxer Rebellion did not hold the same fascination for the Irish nationalist press. It was another continent, another religion, another race. Indeed, when Irish journalists did raise the issue of race, it was not to denigrate Britain or other white European powers for a presumption of superiority over the Asian race; rather journalists used the occasion to characterize the Boxers as part and parcel of the "Yellow Peril."

\footnotetext{
${ }^{362}$ Ibid.
} 
Although the nationalist press did pay lip service to the Boxer Rebellion, there was a noted scarcity of coverage in their papers, with the majority seemingly content to provide updates from Reuters and to reprint feeds from the Evening Telegraph, London Daily Express, and the Times of London. ${ }^{363}$ Unlike the Indian press, there was no widespread condemnation of the atrocities committed by foreign soldiers, nor much mention of the role played by European missionaries in allegedly fomenting agitation among the populace by attempting to convert the Chinese people. One of the only papers weighing in on the causes of the war was the Freeman's Journal, the organ of the Irish Parliamentary Party. The paper attributed the blame for the rebellion to the Chinese imperial authorities - a charge which it claimed "destroys the myth" that the Europeans powers were compelled to entry the fray because the Imperial Government "had found itself powerless to cope" with the rebels. ${ }^{364}$ The editor of the Freeman's Journal reserved its most pointed criticism for Lord Salisbury, fearing that the Prime Minister might attempt to annex territory in the Yangtse Valley—a policy the paper characterized as "insane." 365 The fresh concern about Salisbury was particularly ironic, given his 1898 promise to maintain the Chinese Empire. In that speech, Salisbury had laid out a blueprint for bringing China into the modern age, pledging "to invite it into path of reform, and give it every assistance which we are able to give it, to promote its advance,

\footnotetext{
${ }^{363}$ The feeds were not merely picked up by the Dublin papers, but also by papers across the length of Ireland. The Kildare Observer devoted copy space to a "Who is Who in China" article, reprinted from the Daily Express, while the Connaught Telegraph ran analysis borrowed from the Evening Telegraph.

${ }^{364}$ Freeman's Journal, 22 August 1900.

${ }^{365}$ Freeman's Journal, 3 August 1900. The paper also singled out the British press for fixating on the Chinese government as the sole originator of the Boxer Rebellion, and denying the presence of any moderate party in Peking - something the French press took pains to acknowledge.
} 
and to increase its commercial prosperity."366 In two short years, British policy had rejected cooperation in favor of conquest, sounding bells of alarm for observers in the Irish nationalist press.

The fact, moreover, that much of the Irish press perceived that the British, Japanese, American, and Russian powers were constantly at odds gave Irish critics license to attack not only Britain, but also all things imperial. As the Freeman's Journal caustically noted, "Never was the mutual jealousy of the Western Powers more cynically exhibited than in this conflict with the forces of Eastern barbarism." ${ }^{\text {,67 }}$ Notably, not until after the war did the press in India come to share the Irish view of a fractious relationship amongst the European powers concerning the matter of dividing the spoils of China. "Such a friction is impossible," asserted the Rosnama-i-Mukaddas Hablul Mateen, "so long as there is a fear of a rising of the natives against them."368 Whereas the Irish paper saw in the behavior of the European powers discord born of deep-seated envy and greed, the Indian paper saw only a momentary disruption of European harmony - a united front in the face of native resistance.

Yet, Irish nationalists evinced little of the sympathy for the Boxers apparent in the Indian nationalist press, prompting the question of why Irish journalists failed to connect with the Boxers' cause as they had with the struggle of the Boers. As references to the "Yellow Peril" and Griffith's rants against the Jew-Jingo press indicate, there is much in the nationalist press that can only be interpreted as racist. Certainly, Ireland could not be

\footnotetext{
${ }^{366}$ Cited in the Sydney Morning Herald, 27 July 1900.

${ }^{367}$ Freeman's Journal, 3 August 1900.

${ }^{368}$ Rosnama-i-Mukaddas Hablul Mateen, 27 August 1900.
} 
expected to espouse any of the pan-Asian sentiment expressed by the Indian nationalist press, but there are no Irish nationalist editorials voicing any support for the rebels. Perhaps the rationale for this lack of Irish empathy relates less to the Chinese, themselves, and more to the troops combating the Boxers. Those lone Irish journalists who do defend the Boxers do so not because they admire Chinese resistance to Christianity or rejection of western traditions, but rather because their opponent is the British Empire.

Therein exists one of the most significant differences between Irish attitudes toward the Boxers and the Boers. The war in South Africa was ripe for criticism because Britain - the target of the Irish nationalists' wrath—was the only European power involved, and thus wholly responsible for the course of the war and solely culpable for any atrocities committed. In China, however, the fact that Britain was not the only European power involved was enough to distinguish the Boxer Rebellion as a conflict in which the Irish did not have as much of a national stake. Still, the overall omission of analysis and editorializing in the Irish press is somewhat perplexing, given the chance to criticize the actions not only of British troops in China, but also the behavior of the Protestant missionaries. Both of these themes - occupation by an alien force and religious subjugation at the hands of the occupiers—should have played naturally into the hands of the nationalist press.

If the Irish nationalist press failed to focus its full attention on the Rebellion, the Irish advanced-nationalist press - uncompromising in its insistence on independence for Ireland - was fully engaged with the events in China. Writing in the Workers Republic, socialist James Connolly lashed out at the war as a capitalist device to conquer new 
markets, alluding not only to the aggression the West directed toward the East, but also to the tension that simmered among the Europeans. "The great industrial nations of the world, driven on by their respective moneyed classes," sniped Connolly, "now front each other in the far East, and, with swords in hand, threaten to set the armed millions of Europe in terrible and bloody conflict, in order to decide which shall have the right to force upon John Chinaman the goods which his European brother produces."”69 Connolly reserved special enmity for both the British Empire and, not surprisingly, for the Tsar of Russia, who "speaks to-day of universal peace, in order that when, in the near future, he hurls his armies across the frontier into China, India or Constantinople ... he may be able to point to this action of his as proof that the battle was not of his seeking. ${ }^{270}$ In Connolly's estimation, any professed motives for war other than capitalist greed and the hunger for new markets were wholly lacking in credibility.

In light of Arthur Griffith's avowed animosity to all things British, it is not surprising that the one paper that weighed in with pointed editorial comment on the Boxer Rebellion was Arthur Griffith's United Irishman. Having returned from the Transvaal in 1898, Griffith could not have founded his paper at a more fortuitous moment. The organ afforded him a podium from which to denounce the British and simultaneously launch his nationalist program. Provocatively proclaiming, "I believe there must be something good in any individual, body, or nation which the English press reviles," Griffith proceeded to excoriate the British newspapers for repeating what he

\footnotetext{
${ }^{369}$ James Connolly, “The Roots of Modern War," in Workers' Republic, 18 August 1898. Internet; available at http://www.marxists.org/archive/connolly/1898/08/rootowar.htm; accessed on 31 March 2013.

${ }^{370}$ James Connolly, “British and Russian Imperialism I," in Workers' Republic, 3 September 1898. Internet; available at http://www.marxists.org/archive/connolly/1898/09/britrus1.htm; accessed on 31 March 2013.
} 
considered slanderous lies. ${ }^{371}$ "I have sufficient knowledge of who and what the Boxers are," the editor avowed, "to be aware that they are not robbers and murderers with a penchant for harpooning pious Christians. ${ }^{, 372}$ For Griffith, the question was not whether the Boxers possessed admirable and heroic qualities; rather, he sought solidarity with a people who were fighting to maintain some semblance of independence in the face of encroaching foreigners.

Although his affinity for the Boxer cause was clearly eclipsed by his passion for the Boer campaign, the underlying factor that determined the Irishman's loyalty was the presence of a nationalist underdog stepping into the ring with an imperialist heavyweight. Given his political agenda, it became unimportant whether the Boxers were vanquished by the European Powers. "Yet, though the Boxer fails, why should I not admire him?" asked Griffith. ${ }^{373}$ Answering his own question, the editor summed up the underlying argument: "Ignorant, as we reckon ignorance, conservative, fanatical, he is still an Oriental Nationalist." ${ }^{374}$ This was a back-handed compliment, to be sure, with Griffith expressing his willingness to overlook what he considered the egregious shortcomings of the average Chinese rebel, provided that "Oriental" was vigorously espousing the cause of nationalism. Only then could the editor use the Chinese Boxer as a model for the educated, liberal-minded Irishman to emulate.

Having decided at the outset of the Rebellion that the Chinese were largely blameless, the United Irishman proceeded to enumerate the myriad ways in which the

${ }^{371}$ United Irishman, 23 June 1900.

${ }^{372}$ Ibid.

${ }^{373}$ Ibid.

${ }^{374}$ Ibid. 
foreign powers were the culpable party, journalistically indicting the Europeans on charges of "criminal neglect and criminal folly." at the "ridiculous ultimatum" sent to the Chinese, as well as the attempt to capture Peking, regardless of the fact that there had been no formal declaration of war. According to the United Irishman, the foreign powers should have fully expected the blowback from China. Instead, "Europe and America are aghast at the temerity of the Chinese, at their audacity, their resistance."376 "When the Powers learn history," concluded the article, "they will have learned sense.",377 Griffith and his colleagues rather transparently identified with a proud people subjected to the imperialist whims of a conquering army.

As the events in Peking grew increasingly desperate, so did the description of the Boxer Rebellion in Griffith's paper. What began as the "Chinese Question" in the Foreign Notes section of the United Irishman rapidly transformed into the "Chinese Situation," followed by the "Chinese Crisis," and finally the damning "Chinese Fiasco." Indeed, by the end of July, the paper was referring to China's plight as "the grimmest and most grotesque that has occurred to any country in this century. ${ }^{\prime 378}$ Notwithstanding his own hyperbole, Griffith was quick to pounce on the European press for its own exaggerated reporting: ${ }^{379}$ "Harrowing tales from well informed sources reached the West of terrible things being done in Pekin and of magnificent things being left undone

\footnotetext{
${ }^{375}$ United Irishman, 7 July 1900.

${ }^{376}$ Ibid.

${ }^{377}$ Ibid.

${ }^{378}$ United Irishman, 28 July 1900.

${ }^{379}$ United Irishman, 14 July 1900.
} 
by the Powers," the paper reported, adding sardonically, "Whereupon the autocrat of the breakfast table waxeth wroth and vows perdition to pigtails and disgrace to all and sundry who do not happen to belong to the blessed English race. ${ }^{380}$ Not for the last time would Griffith accuse the British press of spreading rumor and falsehood in pursuance of its national interests. Moreover, the editor could not resist taking a swipe at those who sat safe at home in Britain, confident of their superiority and secure in the knowledge that the sun would never set on the British Empire.

Specifically, the editor denounced the European Press for credulously swallowing whole and then regurgitating propaganda from the region. Griffith would return repeatedly to the subject of the European press, taking them to task for, among other things, their gullibility. "First of all, there came the sensational report of the massacre of the foreign ambassadors. At first it was gravely given out that not only had this the sanction of the Government, but that a special Imperial edict had been issued giving authority to the Boxers in their alleged barbarous acts." 381 "Gradually," noted the paper wryly, "these Shanghai romances are being discredited." ${ }^{\text {"38 }}$ Griffith seemed to delight in debunking the tales of horror: "But later on these redhot reports become watered down, and from a story of a complete wiping out of the foreigners in Pekin we descend the scale 'of sensationalism,' until we know that at least two Legations are still standing a few days ago." 383 The implication was that the European press was unreliable, untrustworthy, and unrepentant in its anti-Boxer bias.

\footnotetext{
${ }^{380}$ Ibid.

${ }^{381}$ United Irishman, 28 July 1900.

${ }^{382}$ Ibid.
} 
Griffith's disdain for the highhandedness with which the European Powers conducted their affairs dictated the manner in which he assigned culpability for the Rebellion. He noted that the European press blamed the Government and people of China, "and urge that Pekin should be razed to the ground as an act of vengeance," whereas the Dowager Empress "has laid the onus of the whole melancholy business on the shoulders of the representatives of the Powers." ${ }^{384}$ Griffith's antipathy toward imperialism was evident throughout the pages of the paper. He prided himself on providing his readers with news unfiltered by the British press - particularly if it bolstered his own political agenda. The United Irishman reprinted in full the opinion of the Amrita Bazar Patrika, which had claimed that "the Boxers are establishing the proper position of man in human polity; a man can never be made a slave; he has the spark of divinity in him." 385 The reference to the Boxers as imperial slaves of the various European Powers clearly resonated with Griffith's own view of the Irish as imperial slaves of Britain.

Indeed, joining in the chorus of criticism leveled by the Indian native press, the United Irishman bemoaned the lack of respect accorded to the ancient Chinese Empire. In the editor's estimation, "China was treated not as a 'civilised' Power of old standing amongst the nations, but like an East African tribe, whose popular outbreak is revenge by wholesale burnings of chief's kraals without distinction. ${ }^{\$ 86}$ Griffith’s paper pointedly

\footnotetext{
${ }^{383}$ Ibid, 14 July 1900.

${ }^{384}$ United Irishman, 21 July 1900.

${ }^{385}$ United Irishman, 4 August 1900.

${ }^{386}$ United Irishman, 21 July 1900.
} 
identified with the plight of the Chinese, viewing the struggle in Asia as one more instance of a subjugated people ready to break its bonds. Whereas the Indian native press frequently portrayed China as helpless prey to the so-called vultures of Europe, the United Irishman altered the analogy. "China at present," claimed the paper, "is like a hedgehog which everyone kicks about as he pleases, not knowing perhaps what it is." ${ }^{387}$ The paper cautioned, however, "when China gets its back up, some of the bristles will annoy those Powers now foremost in the kicking." ${ }^{„ 388}$ The warning was evident: the Chinese hedgehog might appear docile and incapable of defense, but any resort to "unjust, unwise, and impolitic aggression" by the European powers would earn the aggressors a painful comeuppance. ${ }^{389}$

Still, Griffith cautiously backpedaled from his earlier wholesale support of the Boxer cause, explaining, "One does not defend the Boxers: one defends nothing. It is a question as to who exactly it was that caused the state of things which led up to the Government of China being temporarily suspended by an enraged Mob." ${ }^{\text {390 }}$ Given the endless stream of criticism it directed daily at the British Government, it is not surprising that the United Irishman reserved most of its scorn for Britain, elevating it above all the other foreign powers as the prime instigator of the Boxer Rebellion. It was of little consequence that there was no unilateral action on Britain's part that instigated the rebellion. Novelist T.O. Russell, a contributor to the United Irishman, unapologetically asserted, "British greed and British blackguardism has brought about the present state of ${ }^{387}$ United Irishman, 18 August 1900.

${ }^{388}$ Ibid.

${ }^{389}$ Ibid.

${ }^{390}$ United Irishman, 21 July 1900. 
things in that country. ${ }^{, 391}$ More than any of the other Irish publications, the United Irishman was quick to espy the negative effect the Rebellion was having on British forces, mired as they were in the morass that was the crisis in the Transvaal. "Chained as she is in South Africa by the heroic Boers," proclaimed the paper, "she cannot adopt the role of head pacificator to her own advantage, as she did in Egypt in 1882; so she urges Japan to join as her catspaw, to keep the place warm until she is relieved of the incubus in the Transvaal. ${ }^{, 392}$ British forces were, indeed, strained to the breaking point, with Britain continually forced to deploy more troops to South Africa. Japan, by contrast, fielded more than twenty thousand troops in China, supported by a sizable contingent of warships. The implication was that Japan would be Britain's proxy in maintaining order in China.

Demonstrating an understanding of the scope of Britain's troubles in the Transvaal, the writer linked the onset of the Rebellion to the South African conflict, claiming, "It seems an absolute certainty that it was the war in South Africa that brought about the war in China, with all its horrors of murders, tortures, and unspeakable misery. ${ }^{״ 393}$ The writer claimed that whereas the Boxers were initially intimidated by British and other European forces, the knowledge that a small untrained army of Boer farmers, "not half as numerous as the inhabitants of some Chinese country towns," was able to rout the well-armed, professionally trained, numerically superior British forces, provided the Chinese dissidents with the confidence to launch the Rebellion. ${ }^{394}$ Taking a

\footnotetext{
${ }^{391}$ Ibid.

${ }^{392}$ Ibid.

${ }^{393}$ United Irishman, 11 August 1900.
} 
page from the Fenian playbook, Russell concluded that the only credible reason the Chinese Imperial government chose the timing of the revolt against the foreign powers was that they believed "England's difficulty was China's opportunity.",395

In truth, it was not only the Chinese who sought to take advantage of Britain's difficulty in the Transvaal. The United Irishman rather gleefully reprinted an article from La Patrie, in which the French journalist Lucien Millevoye described Britain's “intrigues in China" as utterly hopeless, given her most unfortunate travails in South Africa. ${ }^{396}$ Millevoye saw an unprecedented opportunity for continental Europe to exploit what he characterized as this undeserved stroke of luck, by standing united and "barring the way to English greed." ${ }^{397}$ Griffith was quick to exploit any opportunity he spied to relay to his readers criticism of the British Empire, believing that if even one European power was skewering British policy, the attack lent credence to the Irish editor's constant stream of anti-British rhetoric.

One Irish journalist who, like the journalists of the native press in India, delved deeper into the Rebellion to discern the integral role of religion in the uprising was Frederick Ryan. The Irish playwright and journalist contributed two lengthy articles to the United Irishman, including an analysis of what he perceived as the link between religion and revenge in China. Writing in the aftermath of the crisis, Ryan advised the readership of the United Irishman to consider how they would feel if roles were reversed

\footnotetext{
${ }^{394}$ Ibid.

${ }^{395}$ United Irishman, 16 June 1900.

${ }^{396}$ Ibid. Not only did Irish journalists take an interest in Millevoye's political opinions, but also, the French writer had an abiding interest in events in the Emerald Isle, given that he was romantically involved with Maud Gonne, renowned Irish actress and revolutionary.

${ }^{397}$ Ibid.
} 
and the Chinese dispatched to the west of Ireland a barrage of Confucian and Buddhist missionaries, who "ostentatiously flouted the people's religion." ${ }^{398}$ Whereas the author acknowledged the "litany of massacres and butcheries" ascribed to the Chinese Boxers, he also assailed the Christian press for disseminating "whole cartloads of lies."399 Ryan alluded to a speech by $\mathrm{Wu}$ Ting Fang, the Chinese ambassador to Washington, who commented that the press so readily believed the erroneous news that all foreigners had been massacred that St. Paul's Cathedral had accordingly scheduled a memorial service for the victims. ${ }^{400}$ Ryan observed acerbically that St. Paul's "will have to be a little more careful in the future."401 Even more than their Indian counterparts, Irish nationalist journalists deeply distrusted the so-called official reports emanating from China, and mocked those gullible enough to attach weight to each tale of horror.

Ryan, himself a socialist, also disdained the role of capitalism in the motives of the western powers, which he characterized as rapaciously consuming resources, while forcing the Chinese peasantry into what amounted to slave labor. ${ }^{402}$ Ryan scoffed at the rationales provided by European powers for their incursions into and takeovers of new territories. "In the Transvaal the pretext was Outlander grievances or heaven-knowswhat. In the Philippines it was Spanish tyranny."403 Ryan suggested that the Irish response to a similar double-barreled assault of religion and capitalism would

\footnotetext{
${ }^{398}$ Ibid.

${ }^{399}$ United Irishman, 12 January 1901.

${ }^{400}$ Ibid.

${ }^{401}$ Ibid.

${ }^{402}$ Ibid.

${ }^{403}$ Ibid.
} 
undoubtedly be resentment toward those who "came to save their souls and incidentally annexed any of their belongings that they could." ${ }^{\text {"404 }}$ The writer believed the desperate quest for new markets was, in fact, the underlying motive for Europe, America, and Japan to flex their combined muscles. The slaughter of missionaries and ambassadors was merely a pretext for their actions.

Over the course of the uprising, the majority of Indian nationalist and Irish advanced-nationalist journalists positioned themselves firmly in the corner of the Chinese rebels, but there were distinct differences in their rationales for doing so. Arthur Griffith and his Irish confreres largely adopted their stance as a means of furthering their journalistic assault on the British Government. Chief among their aims-indeed, perhaps the only goal — was to characterize the British as international bullies: single-minded in their imperialist aims; aggressive in their expansionist pursuits; and devoid of compassion as regards the people whom they subjugated. For the editors, there was little real identification with the Boxers; rather, the Rebellion offered yet another opportunity to verbally savage the British—an opportunity Griffith and his colleagues were all too eager to exploit.

The Irish enmity toward the British, however, could take the journalists only so far, particularly when so many other foreign powers were involved. Accordingly, once the summer months of 1900 had passed, even the coverage in the United Irishman became spotty and perfunctory, with brief articles taking the place of analysis and editorial brio. The seeming lack of empathy expressed by the Irish papers with the Chinese people stands in stark contrast to the solidarity the Irish contemporaneously

\footnotetext{
${ }^{404}$ Ibid.
} 
expressed with the Boers. Given that Ireland constituted a Western country, the press could not simultaneously support the Boxers and characterize the conflict as an East versus West concern. Inasmuch as Ireland was a Christian nation, the writers-with Frederick Ryan being the notable exception — were hard-pressed to denigrate the behavior of Christian missionaries. Whereas Ireland was primarily a nation of white Europeans, the journalists either would not or could not join in the chorus of those detecting racial motives for the actions of the European Powers. Thus, in the Irish nationalist press, there is little or no mention that geography, religion, or race-factors that consumed the Indian native press - had any part in initiating the Rebellion or determining the manner in which it was prosecuted by Britain and the other foreign powers.

There is little doubt that native journalists in India deemed the Boxer Rebellion a more complex conflict than that perceived of by the Irish press. Far from viewing this as a simplistic case of the British Empire engaged in a battle versus the Chinese rebels, or even a matter of imperial powers assertively tossing around their combined weight, the Indian journalists uncovered a tangled jumble of disturbing prejudices at the core of the Rebellion. Given that the subcontinent constituted part of Asia, the Indian press was quick to detect an attempt by European powers to impose western ideology and culture on a Chinese nation too weakened by repeated assaults to resist. As India was a nation comprised of Hindus, Muslims, Sikhs, Jains, Buddhists, Zoroastrians, and myriad other religions - all at one time criticized and even ridiculed by British Christian conquerorsthe native press instinctively understood the resentment elicited by the missionaries in China. Lastly, as India was a nation composed of people of color-whose soldiers were 
permitted to fight the yellow Boxers, but not the white Boers - the press instantly detected the role of race underlying the Rebellion.

Underlying many of the differences in the Irish and Indian coverage of the Boxer Rebellion - and, in turn, the Boer War — was the significant matter of national security. While undoubtedly resentful of Britain's perennial presence on the Irish isle, complete with an endless stream of edicts emanating from Dublin Castle, Ireland was never, in fact, in fear of an external attack. Her virtual isolation combined with her proximity to England meant that no other nation was likely to attempt invasion. In addition, although the issue of Britain deploying Irish troops in the service of the Empire would figure dramatically in the Transvaal conflict, Irish troops were not a factor in the Boxer Rebellion. Freed from concerns about security, and with well-trained Irish soldiers stationed at home, Ireland's nationalist journalists truly could seize the opportunity to exploit Britain's difficulties in Asia. By stark contrast, India lived in constant fear of invasion. "Any mention of the word Russia, the mere reading of the letters which form the word," wrote the Basumati, "has somehow the effect of rolling up the heart." ${ }^{, 405}$ The Bharat Mitra was convinced Russia was preparing to invade India by sea, while the Hablul Mateen stated emphatically, "There is no doubt that Russia has the conquest of India at heart. ${ }^{\$ 06}$ The specter of Russia hovered over the writings of India's Bengali journalists, who bemoaned Britain's preoccupation in Asia and Africa, and envisioned a salivating Russian bear waiting to devour an unprotected India.

\footnotetext{
${ }^{405}$ Basumati, 23 November 1899.

${ }^{406}$ Bharat Mitra, 12 January 1901; Hablul Mateen, 14 May 1900.
} 
The fear was not simply a matter of Britain being an absentee landlord. The Hitavadi worried that India had grown increasingly dependent on the protection of Britain. "Under British rule, the Indian people have become much more peaceful, and their valour, military instinct, and self-help have almost disappeared, so that she is no longer in a position to do without England. ${ }^{, 407}$ The doctrine of martial races embraced by the British Army—and drummed into the consciousness of the Indian people—had, no doubt, contributed to this sense of encroaching enfeeblement. Given that Britain was continually increasing the size of its empire, "by depriving one country after another of its independence," the paper fretted that more enemies would arise to challenge imperial might, thus eternally depriving India of Britain's protection. ${ }^{408}$ Moreover, the lack of imperial protection was compounded by the fact that the few Indian troops deemed sufficiently manly and courageous were being dispatched to China, and would undoubtedly return the worse for wear. Given the depletion of military forces on the subcontinent, the Hitavadi was clear on one point: "England ought to have remained neutral in the China affair." ${ }^{409}$ Thus, even those native journalists who sought some measure of independence recognized that England's difficulty—-far from constituting the subcontinent's opportunity— was, in fact, imperiling India.

Questions of national security would continue to factor into the essential differences between Irish and Indian coverage of Britain's imperial wars. Indeed, it is difficult to examine coverage of the Boxer Rebellion in isolation, given that the timing of

\footnotetext{
${ }^{407}$ Hitavadi, 17 August 1900.

${ }^{408}$ Ibid.

${ }^{409}$ Ibid.
} 
the uprising paralleled that of the war in the Transvaal. Yet, while the Boer War would produce more of a lasting material impact on the Empire, the crisis in China offers an ideal prism through which to examine Irish and Indian attitudes toward race and religion. Clearly, India's native press felt more of an affinity with China and the rebels, and was disturbed by what it saw as a foreign crusade to impose Christian religion and western thought on the continent. Ireland's nationalist journalists were less invested in the outcome of the conflict, viewing the Chinese as allies who helpfully distracted the British lion, permitting the Irish to go about the business of furthering their nationalist agenda. Although the Boxer Rebellion endured for three years, intense British involvement in the conflict was actually of brief duration, lasting only a few months. ${ }^{410}$ Moreover, unlike the Boer War, in which the British Empire struggled alone against enemy forces, the Eight-Nation Alliance marshaled its combined forces in China, ostensibly ensuring that no one nation bore the brunt of the enemy's attack. Thus, it would seem that the impact of the Boxer Rebellion on the fortunes of the British Empire pales in significance beside the cataclysmic events of the Second Boer War.

The critical period of the Boxer Rebellion was of only short duration, affording journalists in India and Ireland a brief window of opportunity to question imperial actions and shape national attitudes. Yet, the questions of race and religion raised by Indian journalists would remain at the forefront of their coverage of the Empire, just as Irish

\footnotetext{
${ }^{410}$ There continues to exist scholarly controversy regarding the timing and the nature of the connection between the Boxers and the Qing imperial government. Indeed, Joseph Esherick asserts that "uprising" is a more appropriate term to describe the pivotal events in China, arguing that the use of the term Rebellion is misguided, as it erroneously gives the impression that the Boxers rebelled against the Qing government. The author notes that it was not until after the movement was suppressed that the term Rebellion came into use. "In order to save face for the Qing court and the Empress Dowager at its head," explains Esherick, "the fiction was created that the Boxers were really rebels." The Origins of the Boxer Uprising (Berkeley: University of California Press, 1987).
} 
attitudes toward the British would become even more entrenched as the new century dawned. The Boxer Rebellion gave Indian and Irish journalists a chance to flex their muscles and stockpile ammunition; the escalation of the Boer War would see them launch an unprecedented attack. 


\section{"Conscience Has Lost Its Hold": The Boer War Redux}

The pattern had been set-simple in its design, yet dramatic in its execution. On a July night in the little town of Bethlehem, deep within the former Orange Free State, British troops surrounded a farmhouse and cleared women and children from the household, allowing them to grab only a few meager possessions before chasing them into the night. ${ }^{411}$ On the orders of General Sir Archibald Hunter, the command was given to set the farm ablaze. Columns of smoke billowed into the air, the acrid smell filling the lungs - a warning to all those who would aid and abet the Boer guerillas, more determined than ever to oust the British from their homeland. General Hunter's quarry, the wily Boer General Christiaan Rudolph De Wet, had escaped into the mountains, and would harry and harass the British forces for two more long and bitterly-fought years. The rejoicing in Britain over the end of the Transvaal War had been premature and tragically short-lived.

Although initially cloaked in secrecy, the policy of farm-burning could not long remain hidden from the public_-particularly as young soldiers penned letters home describing in detail their new orders and the devastating consequences of those commands. Given that Lord Roberts and other officials were studiously funneling their own version of events in the Transvaal to friends in the British press, the clandestine letters and reports received by editors in Dublin from their own contacts in South Africa

\footnotetext{
${ }^{411}$ On May 28 1900, Lord Roberts had proclaimed that the Orange Free State would henceforth be known as the Orange River Colony.
} 
enabled the Irish press to provide an alternate version of the truth. ${ }^{412}$ Dutifully forwarded to the newspapers, those letters would feature prominently in the columns of the advanced-nationalist press in Ireland. Headlines such as "We Burnt All the Farms," "It Burned Brightly," and "Every Farm We Burn" ignited their own fiery responses among the readership and fueled increasing animosity toward the British Government and the methods the military had elected to adopt. ${ }^{413}$ Britain's scorched earth policy in the Transvaal, involving not only the burning of farms and the slaughtering of livestock, but also the imprisoning of women and children in concentration camps, aroused passions from friend and foe alike. Questions persisted as to why a mighty imperial force such as Britain felt compelled to resort to such draconian measures against an enemy as seemingly insignificant as the Boers.

The contextualizing of the Boer War afforded the Indian native press and the Irish nationalist press an unparalleled opportunity to forward their agenda, as it permitted them to openly debate the policies of the British Government and critically assess the Empire's standing among European nations. Leading the interrogation were the advancednationalist press in Ireland and the native press in India. Throughout the duration of the Second Boer War, this select group of journalists believed it carried a responsibility not only to inform the masses about events in the Transvaal, but also to diligently interpret each new occurrence for its readership. Thus, it was not enough to provide the outcome of a particular battle or the latest casualty numbers; the press scrupulously analyzed each

${ }^{412}$ For more on Roberts' cunning use of the British press, see Kenneth O. Morgan, "The Boer War and the Media," in Twentieth Century British History, (Vol. 13, No.1, 2002), 1-16. Morgan notes that the Boer War was such a seminal event because the 1870 Forster Education Act had ushered in a new era of mass literacy. The fledgling readership was keen to read and digest all the sensational news coming from the front in South Africa.

413 “Three Extracts,” Freeman's Journal, 20 December 1900. 
decision and military tactic — from farm-burning to the internment of women and children - and, most importantly, provided context for each new phase of the war. Accordingly, each reverse was interpreted either as a military blunder brought on by pride, or a demonstration of outdated British military strategy, while each victory was simply seen as inevitable, given Britain's superior numbers. Hence, whether enduring the siege at Mafeking or emerging victorious at Pretoria, Britain was rarely portrayed in a positive light in the columns of nationalist newspapers.

Given this predilection for placing the most unflattering interpretation on the Empire's conduct in the first year of the war, it is not surprising that Britain's adoption of a scorched earth policy to subdue the Boers left it vulnerable to savage journalistic attacks in both Ireland and India. Hubris and military ineptitude might be indications that Britain's power was waning; however, the burning of farms, the slaughter of livestock, and the internment of Boer women and children in concentration camps were, in the capable hands of Arthur Griffith or Bal Gangadhar Tilak, definitive proof that the Empire had lost any sense of morality or humanity. As the Som Prakash mournfully intoned, "Conscience has lost its hold upon England." ${ }^{414}$ Ironically, Britain's attempt to demonstrate to the Boers and to the world its military might actually empowered and emboldened the press to criticize the Empire with a new ferocity—and to persuade its readership that the time to proclaim independence from the Empire was fast approaching. Britain's difficulty was truly becoming the nationalists' opportunity.

In Bombay, Bal Gangadhar Tilak-newly released from prison, after serving a sentence for sedition — assumed the leadership of the anti-imperialist forces in the native

${ }^{414}$ Som Prakash, 13 August 1900. 
press. On 27 July 1897, pursuant to Section 124-A of the Indian Penal Code, the Government of India had arraigned and imprisoned Tilak on charges of exciting feelings of disaffection and attempting to excite feelings of disaffection, based on the content of articles appearing in the 15 June issue of the Kesari. ${ }^{415}$ Like Arthur Griffith in Ireland, Tilak was both a political leader and a journalist, revered both for his staunch advocacy of the Indian peasant and passionate defense of India. Tilak's presence in the largely middle-class Indian National Congress enabled him to become intimately acquainted with political movements and trends, while his stewardship of the English-language Mahrátta — and especially the Marathi-language Kesari (“The Lion”)—afforded him a platform from which to present his nationalist ideas to the masses. His crusade earned Tilak the soubriquet Lokamanya ("Beloved Leader of the People"), and the Kál fulsomely hailed him as "our national hero, the fountain source of our agitation, the father of the Swadeshi and the boycott movements, and the guardian of national education. ${ }^{416}$ Years later, Jawaharlal Nehru would credit the editor with being the first Indian nationalist to reach the masses.

\footnotetext{
${ }^{415}$ Section 124-A dealt with charges of sedition and read: "Whoever, by words, either spoken or written, or by signs, or by visible representation, or otherwise, brings or attempts to bring into hatred or contempt, or excites or attempts to excite disaffection towards the Government established by law in India, shall be punished with imprisonment for life, to which fine may be added, or with imprisonment which may extend to three years, to which fine may be added, or with fine." Cited in the Indian Penal Code; available at http://indianlawcases.com/Act-Indian.Penal.Code,1860-1557; Internet; accessed on 25 December 2012. In the articles cited by officials, Tilak had alluded to Shivaji's slaying of the Muslim officer, Afzal Khan, and printed the poem "Shivaji's Utterances," which read, in part: "What ruin is this! / The foreigners teasingly and forcibly drag away Lakshmi by the hand / With her plenty has run away and health has followed." The Government was highly suspicious of the timing of the articles, given that Tilak published the offending material shortly before the assassination of Plague Commissioner Rand and army officer Lieutenant Charles Egerton Ayerst on the evening of Queen Victoria's Jubilee. Poem cited in Stanley A. Wolpert, Tilak and Gokhale: Revolution and Reform in the Making of Modern India (Berkeley: University of California Press, 1977), 99.

${ }^{416}$ Kál, 24 July 1908.
} 
Despite the victory of Roberts in Pretoria, few in the Indian press believed that hostilities were drawing to a close. Already, several papers had decried the almost universal rejoicing over the prospect of the war's end. Now, with news reaching India of continued Boer resistance via guerrilla tactics, more papers weighed in on what the next phase of the war would portend for the combatants. The Puduvaimitran-the most vocal of the vernacular papers in Madras - mocked the very idea that the war had ended, charging the British with deception and exaggeration, while the Puduvai Nésan accused Lord Roberts of spreading false rumors among his troops, "in order to instill courage into their minds. ${ }^{417}$ The latter paper warned about the damage the war was inflicting on British prestige, and asserted that the Boers would ultimately prove victorious, "driving the British to seek a snug corner to hide their heads in." ${ }^{, 418}$ The proclamation by Lord Roberts announcing the annexation of the Transvaal was greeted with derision by the Puduvaimitran, which scoffed at the British presumption and lauded the persistence of the Boers, "still fighting with unabated vigour and undaunted courage."419 Resembling Irish nationalist newspapers in tone, these overt criticisms boded ill for the Empire, indicating that some native journalists had gone beyond polite questioning of policy to wage a frontal attack on British honor and prestige.

Editors in the Indian native press seized on several troubling links between India and the Boer War to drive home their message that Britain would callously and opportunistically continue to use the subcontinent as the British Government saw fit; the

\footnotetext{
${ }^{417}$ Puduvaimitran. 6 October 1900, Puduvai Nésan, 20 October 1900.

${ }^{418}$ Puduvai Nésan, 20 October 1900.

${ }^{419}$ Puduvaimitran, 20 October 1900.
} 
thoughts and wishes and desires of Indians being of little or no importance. In Bombay, Tilak unapologetically used the pages of the Kesari and the Mahrátta to thump the Empire resoundingly. As the Mahrátta was published in English, it was the Kesariacknowledged by officials as "the most influential of the vernacular papers"- and the Kál—described as "the most virulent and treasonous in its writings" - that provided the most persistent and pugnacious criticism of the British prosecution of the war. ${ }^{420}$ As the war entered its second winter, the Kesari attempted to knock the British Empire down a few pegs, suggesting that British forces would never be able to make peace in the Transvaal, as long as the British Government "continues to show an attitude of haughtiness and arrogance toward the Boers. ${ }^{, 421}$ Implicit in this criticism was the understanding that Indians had also been victims of Britain's arrogant policies.

The fact that political leaders such as Bal Gangadhar Tilak in Bombay and Surendranath Banerjea in Bengal (the Bengalee) had access to their own newspapers meant that they were at liberty to use these papers in support of the nationalist causeinstilling suspicion, distrust, and even disaffection in their readership. ${ }^{422}$ Inadvertently, Britain's maladroit management of the war in the Transvaal continued to hand the native press issues with which to persuade the masses of the justice of the nationalist agenda. The lack of Indian troops deployed in the conflict, the deportation of Boer prisoners of

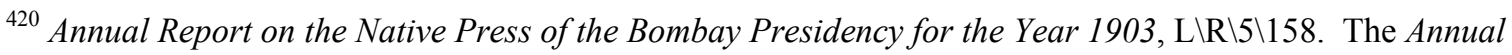
Report noted that the Mahrátta "reflected the views of the Kesari though in a guarded and more moderate tone."

${ }^{421}$ Kesari, 26 February 1901.

${ }^{422}$ Surendranath Banerjea (1848-1925) was the founder of the Indian National Association in 1876 (together with Anandamohan Bose), and was elected President of the Indian National Congress in 1895, where he maintained an influential role as leader of the Moderates. Just as Tilak, leader of the Extremists, earned the affectionate name Lokamanya, or "Leader of the People", the Indian people affectionately referred to Banerjea as Rashtraguru — "Teacher of the Nation." Banerjea founded the Bengalee in 1879.
} 
war to India, the treatment of Indian immigrants in South Africa, and especially the brutal policies adopted by the British army in the second year of the war, all provided ammunition to editors seeking to convince their readers that the Empire did not, in fact, have their best interests at heart. By repeatedly questioning British motives for the war and criticizing the Government's conduct of the prolonged conflict, the native press in India was laying the groundwork for a nationalist platform it would continue to construct after the war's termination. The Empire may have long mined India for its human and natural resources, but now members of the native press were learning to exploit Britain's handling of its imperial wars for their own nationalist purposes.

Whereas there was a dearth of Indian troops making their way to South Africa, India was now inundated by a veritable flood of Boer prisoners of war shipped to the subcontinent for the duration of the conflict. In an effort to diminish possibilities of escape into the South African countryside - and to absolve itself of any responsibility for feeding those who had been captured - the British army deported more than 25,000 prisoners of war to colonial outposts that included St. Helena, Ceylon, and Bermuda. In India, the hill station of Ahmednagar was one of more than a dozen repositories of Boer prisoners of war, and ignited a heated debate in the Bombay papers over the choice of location, the cost to India, and the impact of the presence of the prisoners.

The press played an integral role in disseminating knowledge of the camps, and its questioning of Britain's choice of India as a detention center for Boer prisoners gave rise to a debate over the role that the Empire had assigned India to play in the conflict. The Jám-e-Jamshed — described by officials as a "gossipy society journal of the Parsis,"- grumbled in protest, "We do not see why India particularly should be pestered 
with the inconvenience of detaining a band of Boer prisoners. We are sure other dependencies of the Empire like Australia or Ireland would have treated a similar proposal with scant respect." 423 The Karachi also objected to the influx of Boer prisoners, declaring, "We have already got quite a number of these ragged gentry encamped in our midst, and though, of course, we have the highest respect for their patriotism and valour . . they do not seem to be exactly the sort that one would like to associate and rub shoulders with." 424 The paper, moreover, expressed its anxiety about Britain's policy of housing the prisoners in India, not merely on the grounds of inconvenience, but also out of concern for the peril they posed. "They will be a disturbing factor in our populace, and may even prove a source of danger to the Government," the Karachi warned, adding ominously, "Government does not seem to know the danger it is courting." ${ }^{, 425}$ Sounding an even more somber note as the war neared its end, the Gujarati criticized Curzon for believing natives would attribute the number of prisoners to Britain's military prowess. The paper reminded officials that "the loyalty of the Indians is not due to England's might, but to her integrity and sense of justice." ${ }^{426}$ India would take pride in its place in the Empire, only if the Empire placed its duty to conscience ahead of its desire for conquest.

\footnotetext{
${ }^{423}$ Annual Report on the Native Press of the Bombay Presidency for the Year 1903; Jám-e-Jamshed, 15 February 1901. There was a bit of comical confusion when the Phoenix criticized the choice of Ahmednagar for a prison, calling it "one of the unhealthiest places in India," only to retract the statement a week later, stating, "It is not the sink of disease and death we had been led to think." The Phoenix, 8 May 1901; 15 May 1901.

${ }^{424}$ Karachi, 29 September 1901.

${ }^{425}$ Ibid.

${ }^{426}$ Gujarati, 18 April 1902.
} 
Underlying the Indian concerns about events in South Africa was the issue of race. The native press persistently characterized the conflict as the White Man's War, effectively persuading its readership that the British and the "Dutch" behaved in a manner that was not merely incomprehensible, but unconscionable. As the war entered its second year, the Persian newspaper Rosnama-i-Mukaddas Hablul Mateen in Bengal voiced its suspicion of European motives, stating, "It is only for the sake of self-interest that the European nations make friendships with other nations. Their promise, their agreement, their friendship and their patriotism—all these are as hollow as their bombastic cilivisation.",427 Worried, Banerjea's Bengalee opined, "This paper is afraid that the unequal treatment of races is being carried on with a view to conciliating the Boers, who, with their old-fashioned Christianity, which treats the children of Ham as the legitimate slaves of mankind, would strongly resent any suggestions for the 'equality of the Indians. ${ }^{, 428}$ The paper reminded its readership that one of the justifications for the war had been the cruel treatment of Indian workers, and that Britain had promised it would secure "equal rights of civilized races." "the tune is changed to "equality of all the white races." ${ }^{.430}$ There was an underlying suspicion that the warring Europeans were more united than divided, particularly as concerned the natives of South Africa and the Indian immigrants.

In a similar vein, the Indian Spectator professed confusion at the position of the British Government vis à vis the future of the Indian immigrants, stating, "We do not

${ }^{427}$ Rosnama-i-Mukaddas Hablul Mateen, 17 December 1900.

\footnotetext{
${ }^{428}$ Bengalee, 8 June 1901.

${ }^{429}$ Bengalee, 5 June 1901.

${ }^{430}$ Ibid.
} 
understand Mr. Chamberlain's statement that the status of Indians in South Africa is a matter of considerable complexity."431 The paper provided its own rationale for the Government's compliance in the segregationist policy, asserting, "We see no difficulty except the narrow-minded jealousy of British settlers who are more influenced by selfishness and race prejudice than by higher political considerations."432 Paranjape's Kál was even more pessimistic in its assessment of the global situation, warning, "The white colour is about to annihilate the red, black and yellow colours and Jesus Christ has almost eaten up the kernel and given the shell to Muhammad, Manu and Confucius.",433 The editor's double-barreled comment not only assailed Europe's assumption of racial superiority, but also suggested that Christians were determined to subvert India's own revered religions.

As if to provide more fodder for this argument of the Indian native press, the lull in the fighting in South Africa had coincided with the outbreak of intense hostilities in the Boxer Rebellion, allowing the papers to focus attention on yet another imperial war in which white European Christians seemingly conspired to determine the destiny of "uncivilized" Asians. The press utilized this well-timed ammunition to remind their readers of India's dependence upon the British Empire - an entity that apparently viewed both Africans and Asians as little more than heathens in need of instruction, correction, and permanent subjugation. By using the Boer War and the Boxer Rebellion to underscore racial and religious distinctions, the native press laid the groundwork for a

\footnotetext{
${ }^{431}$ Indian Spectator, 11 August 1901.

432 Ibid.

${ }^{433}$ Kál, 6 September 1901.
} 
post-war nationalist agenda, which sought to persuade Indians that their best hope lay in a program of self-reliance, rather than prolonging the state of dependency upon the British. The Kál, therefore, urged its readers to glean what it hoped was the appropriate lesson from the war in South Africa, stating, "the Boers are not only lovers of independence, but that they are determined to make any sacrifice for preserving their liberty, instead of surrendering and living under foreign yoke." ${ }^{, 434}$

As the war progressed, native papers in Bombay and Bengal took the lead in instilling in their readership a desire to break free from an empire whose behavior it deemed unconscionable. After decrying Lord Kitchener's plan to forever banish all Boer prisoners of war and to brand as murderers those who killed British soldiers, the outspoken Hitavadi in Bengal mourned, "How barbarous is the policy adopted by the generous English people in order to extinguish the fire of heroic patriotism in a gallant nation!”435 In Bombay, the Phoenix, noted for its support of the Indian National Congress, was equally appalled by the policy, charging, "The etiquette of war might permit this kind of thing, but every sentiment of humanity imprinted by God on the flashy tablet of the human heart shrinks and recoils from it with horror." ${ }^{, 46}$ British conduct in South Africa was alienating not only those extremists who were predisposed to criticize the Empire, but also those who normally couched their views in more moderate language. Not all criticism, however, was directed at the Empire. Just as they promoted pan-Asian sentiment in supporting the Chinese against the forces of Christian Europe, the

\footnotetext{
${ }^{434}$ Kál, 29 March 1901.

${ }^{435}$ Hitavadi, 23 August 1901.

${ }^{436}$ Phoenix, 31 August 1901.
} 
Indian nationalist papers repeatedly contrasted the independence-loving Boers-so willing to fight for their country — with the subservient Indians, who valued compliance and cooperation over confrontation. The Prekshakm informed its readers, "Although the Boers are destined to become extinct, they do not yield because they are buoyed up by the delusive hope that their love of liberty will be a lesson to the whole world." ${ }^{, 437}$ The Gurakhi also pointed out the obstacles that would prevent India from emulating the Boers and tasting the "heavenly nectar of independence," stating, "Our case is not like theirs. There are no factions amongst them as there are amongst us. They are not like us wanting in sense, jealousy of one another's prosperity and addicted to bribery, but have been fighting for the last two years firmly and unitedly for their own independence., ${ }^{, 438}$ The papers repeatedly held up a mirror to their readers, intent on identifying the flaws that might foil Indian aspirations of independence.

Throughout the first year of the South African conflict, the Indian native press had debated Britain's motives, questioned the Empire's refusal to deploy Indian troops, and worried about the impact on British prestige of the initial military reverses. Despite the implied (and even occasional overt criticism), the tone of the press had remained cordial and diffident, keen to demonstrate its loyalty. Indeed, J.D. Rees, a colonial administrator in India, extolled the loyalty of the native press during the Boer War, proclaiming, "never before in its history did the Indian Press brush aside all smaller issues, forget all its disagreements with the Government and its servants, and offer up one loud, continuous and evidently sincere prayer for the speedy arrival of that victory, which they never

\footnotetext{
${ }^{437}$ Prekshakm, 2 July 1901.

${ }^{438}$ Gurakhi, 11 September 1901.
} 
doubted would be ours. ${ }^{" 439}$ Rees did acknowledge a sole complaint registered by the Native Press - in the matter of the Crown's refusal to employ Indian troops against the Boers - which Rees attributed to the troops ardent desire to "share the present dangers and eventual triumphs of the campaign." ${ }^{, 40}$ Moreover, he conceded that the attitude of the Native Press might even be characterized as pro-Boer, particularly concerning the rationale for the war and the run-up to the conflict.

When the British generals chose to resort to a scorched earth policy in South Africa, however, the demeanor of the native press noticeably altered, becoming more aggressive and obstreperous. Whereas the native press castigated Germany for the atrocities committed in the Boxer Rebellion, and simultaneously praised the British soldiers for refraining from engaging in acts of terror, the Boer War rattled the image of unassailable British conscience and morality. The merciless policy pursued by the British forces in the Transvaal was unfathomable to those in the press who had long boasted of British liberality and generosity. The Hitavadi provided a litany of British acts of war that it characterized as outrages, including the looting of villages, "reducing whole villages to ashes," and especially the expulsion of women and children from their homes. ${ }^{441}$ As reports of slaughtered horses and burned farms and homesteads filtered out of South Africa, the native press functioned as the conduit by which the Indian masses became aware of each act of war.

\footnotetext{
${ }^{439}$ Rees, J.D. "The Native Indian Press," in The Nineteenth Century and After: A Monthly Reader (May 1901, Volume 49), 818.

${ }^{440}$ Ibid.

${ }^{441}$ Hitavadi, 18 January 1901.
} 
It was the fate of Boer women and children, in particular, which shattered Indian faith not only in the rightness of the British cause, but also in the very nature of the British Empire. Drawing the parallel to Rome's treatment of Carthage, the Champion blazoned the headline "Delenda est South Africa!" and proclaimed, "This is the eternal war-cry of the Jingos with Chamberlain Africanus at their head." ${ }^{442}$ Although not wholly absolving soldiers of blame for their deeds, the paper was quick to lay the blame for the policy squarely on the shoulders of Britain's politicians, explaining, "We cannot, and we will not, believe that British soldiers and British officers can relish the work of devastation and cruelty, which is revolting to all who are not blinded by passion and prejudice." ${ }^{\$ 43}$ The Champion detailed the litany of tactics employed by the British in their attempt to subdue the Boers, charging, "The burning of farms, the desolation of homes, and the measures from which women and children suffer are irreconcilable with the bravery of the soldiers or the chivalry of officers. It is the men who led England into the war that are plunging England into this disgrace." ${ }^{444}$ Horrified that British troops would starve Boer animals by burning their fodder, the always-vocal Kál sarcastically wished the British better luck forcing the Boers to surrender using this new tactic than they had burning the farms of their opponents. "May this new trick at least be successful! Otherwise the next expedient would be that of burning the Boers themselves!"445 The

\footnotetext{
${ }^{442}$ The Champion, 13 January 1901.

${ }^{443}$ Ibid.

${ }^{444}$ Ibid.

${ }^{445}$ Kál, 8 June 1901
} 
paper was quick to add, "Of course there would be nothing improper even in such conduct, for it would doubtless be suitable to Christian charity and western morality!"446 Shivram Mahadev Paranjape, the Kál's editor, once again used the war in South Africa to criticize not only British military policy, but also western assumptions of superiority.

Expressing profound horror at the stories emanating from the concentration camps, the Bombay-based Native Opinion wrote in sorrow, "The starving of the Boer women and children is certainly monstrous and 'dishonouring' to a nation professing to be Christian. ${ }^{, 477}$ Referring to reports of aberrant Boer behavior detailed in the British press, the paper scoffed at the "scanty accounts" and opined that "the barbarous Boer shows more chivalry and large-mindedness towards his antagonist than the civilised Englishman." ${ }^{448}$ In Bengal, the Hitavadi expressed its horror, stating, "The stories of oppression which are reaching Britain even under such censorship are enough to make one's hair stand on end." ${ }^{449}$ The paper added, despairingly, "The nation which is famous for its kindness and liberality, manliness and sense of justice has come forward to crush its enemies in the manner of a uncivilised people." ${ }^{450}$ According to a Government of India translator, Bal Gangadhar Tilak's Kesari expressed shock that while women and children "are kept ... on insufficient food and are dying in large numbers on account of typhoid fever, the Boer prisoners in India should be enjoying themselves and making

\footnotetext{
${ }^{446}$ Ibid.

${ }^{447}$ Native Opinion, 24 April 1901. Official estimates place the number of Boer deaths-men, women, and children - in the concentration camps between 18,000 and 28,000. Pakenham, 607.

${ }^{448}$ Ibid.

${ }^{449}$ Hitavadi, 18 January 1901.

${ }^{450}$ Hitavadi, 18 January 1901.
} 
merry." ${ }^{451}$ In sharing its dismay over the plight of 63,000 Boer women and children housed in concentration camps in South Africa, the paper managed to expose the stark difference between their fates and those of the Boer prisoners in India.

Beyond the impact of the atrocities in South Africa on British prestige, the native press correctly predicted the effect of the carnage on the Boer resisters. When reports of British soldiers burning houses filtered back to Bengal, the native-owned Bengalee expressed fear that such acts would only prolong the war. "They will naturally increase the Boer's love of independence," stated the paper, "which is not calculated to evaporate at the sight of burning homesteads and famished children, of looted property and insulted women."452 The Hitavadi sounded much the same sentiment, querying, "What consideration can those people have for laying down their arms, who have lost, by the barbarity of British soldiers all they possessed on earth, house and home, property and relations?"453 The Persian Rosnama-i-Muáddas Hablul Mateen stated unequivocally, “The Boer does not die even at death's door, and it is not likely that the Boer fire will be quenched before another year has passed away." ${ }^{454}$ In Bombay, the Kesari voiced its esteem for the Boer farmer, who "is still fighting with energy against such a formidable enemy as the British, although he sees that his wife and children are under British custody, that his farm is destroyed, and that the whole of his land has been occupied by the British army." ${ }^{455}$ Even Tilak's more diplomatic paper, the English-language

\footnotetext{
${ }^{451}$ Kesari, 18 July 1901.

${ }^{452}$ Bengalee, 13 February 1901.

${ }^{453}$ Hitavadi, 31 May 1901.

${ }^{454}$ Rosnama-i-Mukaddas Hablul Mateen, 4 October 1901.
} 
Mahrátta, questioned British accounts of impending victory, informing its readers, "We are told every day of so many Boers being killed and captured, and yet after a prolonged occupation of South Africa by about 200,000 British soldiers we find a full contingent of 16,000 Boer troops remaining in the field." ${ }^{, 456}$ In pointing out the disparity between British accounts and reality, Tilak left his readers with the impression that the War Office was covering up British military ineptitude. The Indian nationalist press was no longer simply parroting the propaganda received from the War Office; it was interpreting and analyzing news - in the process teaching the people the value of forming their own opinions and standing up for their beliefs.

The endless stream of comments regarding the protracted nature of the conflict served not only to communicate the fairly obvious fact that the war's end was far from imminent, but also reminded readers that the British Empire was distracted from the business of India by a rugged group of Transvaal farmers willing to fight and die for their country. The cold reality, claimed the papers, was that India was suffering through a catastrophic famine; yet Britain was too preoccupied with Boers and Boxers to think about bread. The implication was that the only way to make Britain pay attention was to emulate the Boers in ferocity and fervor.

The concluding years of the Second Boer War saw an increase in the number of allusions to Ireland made by the native press within the Bombay Presidency, the most politically astute of the provinces - perhaps owing to the presence of the Indian National

${ }^{455}$ Kesari, 24 September 1901. The Kaiser-i-Hind - considered "the most rabid of the pro-Congress papers"- ruthlessly disparaged the character of the military, charging that the "rot in the English army ... is of long standing," and had been hidden from the view of the British public by the complicity of an "unscrupulous press." Annual Report on the Native Press of the Bombay Presidency for the Year 1903; Kaiser-i-Hind, 3 November 1901.

${ }^{456}$ Mahrátta, 19 May 1901. 
Congress in its midst. The references provide evidence that the press in India saw the value of paying attention to the Irish example, though there existed some confusion as to whether that model should prove inspirational or cautionary. "The example of Ireland is not calculated to cheer up a dependency like India, opined the Mahrátta." ${ }^{, 457}$ The paper enumerated the myriad links between Ireland and Britain—from religion, caste, color, to education and the arts, to the well-paid employment opportunities the Irish enjoyed in the arena of public service. Moreover, the Mahrátta pointed out to its readership that Ireland had representation in Westminster, and could therefore reap "the glory and rewards of the Empire." 458 "And yet the result of the active work of Irish patriots during the last sixty years from Daniel O'Connell onwards," intoned the paper, "has been that Ireland, after a century of the operation of the Act of Union, is now face to face not with the repeal of that Act, but its modification in such a way that her franchise or representation in Parliament would be cut off by about 40 per cent." ${ }^{, 459}$ The implication was clear: if Ireland, with its numerous ties to Britain, could not bring Home Rule to fruition, or even maintain its strong voice in Westminster, what chance did India have of winning concessions from Britain?

The pro-Congress Shri Savaji Vijay drew yet another unfavorable comparison between the Irishman and the Indian, in terms of the former's disloyalty to the Empire, and the latter's ingrained "loyalty and gentleness." 460 "The Irish are not only disloyal at heart, but seem to delight in parading their disloyalty," charged the paper

\footnotetext{
${ }^{457}$ Mahrátta, 29 September 1901.

${ }^{458}$ Ibid.

${ }^{459}$ Ibid.

${ }^{460}$ Shri Savaji Vijay, 25 January 1902.
} 
disapprovingly. ${ }^{461}$ Yet, given Ireland's rejoicing at each defeat of the British and the demonstrative Indian support of the Empire, the paper wondered why it was India's nationalists who were branded with sedition. ${ }^{462}$ "We do not know what Government would do, if India were to follow the methods of Ireland," mused the Shri Savaji Vijay, before dismissing the possibility out of hand: "But, of course, there is no denying the fact that India will never adopt such methods. ${ }^{263}$ The double standard adopted by Britain in how it treated the native press in India and the nationalist press in Ireland was provoking an element of resentment, and a willingness to entertain other options than devout loyalty.

For its part, the Kál worried that the Irish had reached the point at which they would demand independence outright, and if the request remained unrequited, then war with Britain would soon follow. "We are afraid Ireland may soon become a second Transvaal," pronounced the paper. ${ }^{464}$ The Mahrátta reminded the Government that it had only itself to blame "for the gloomy outlook in Ireland." ${ }^{, 65}$ It is by justice and love that the heart is won and not by fear or coercion.” As the war neared its end, the Kál painted an even starker portrait for its readers, asserting, "England holds the Indians, like the Irishmen, between her jaws, and the consequences of this state of things are no less keenly felt in India than in Ireland. ${ }^{466}$ Implicit in the brief statement was a simple truth:

\footnotetext{
${ }^{461}$ Ibid.

${ }^{462}$ Ibid.

${ }^{463}$ Ibid.

${ }^{464}$ Kál, 31 January 1902.

${ }^{465}$ Mahrátta, 27 April 1902.
} 
Britain not only had to be apprehensive about Ireland becoming a second Transvaal, but also it needed to be equally concerned that India would become a second Ireland. ${ }^{467}$ Still, the paper chastised Ireland for its intransigence in the face of a British victory in South Africa. "If they cannot forget their grievances for a moment and join in the chorus of joy like the Indians," scolded the paper, "we must needs call them extremely ungrateful." Regardless of its reputation as an anti-Government agitator, the Kál did not hesitate to take Michael Davitt and the Irish to task for not celebrating the long-awaited peace.

Inasmuch as the native press was beginning to identify similarities between Ireland and the subcontinent, the final year of the war showcased one of the more pronounced differences between coverage of the conflict by the Indian and Irish press- $\mathrm{a}$ difference that foreshadowed the religious contention of the ensuing decades in India. The atrocities in the concentration camps led not only to strident Indian nationalist attacks on the Empire, but to a broader attack on Christianity as made manifest by the behavior of the British. "One cannot but feel great respect for Christianity as he ponders upon this kind act of England," pronounced the Kál. ${ }^{469}$ "The followers of Christ, who has been described as the Prince of peace," wrote the paper with dripping sarcasm, "have been instrumental in bringing about the death of twelve thousand women and children, in

\footnotetext{
${ }^{466}$ Kál, 16 May 1902.

${ }^{467}$ Interestingly, at war's end, the Gujarati worried that the conditions of the peace might transform the Transvaal into a second Ireland "on a wider scale," while the Kál gloomily predicted, "if England continues to rule the Transvaal unrestrained, it is beyond the shadow of a doubt that the latter will gradually get more and more entangled in the meshes of servitude until in a few years' time it becomes another Ireland or India." Gujarati, 8 June 1902; Kál, 13 June 1902.

${ }^{468}$ Kál, 20 June 1902.

${ }^{469}$ Kál, 10 January 1902.
} 
addition to the large numbers of men they have killed on the battlefield."470 Noting that the capture and killing did not even cease during Christmas, the Kál mockingly professed sorrow that the subcontinent was not a Christian nation: "Surely, India would be extremely happy if she were to embrace this religion, and it is a matter for regret that such a consummation does not seem possible in spite of all the zealous efforts made by Christian missionaries to bring it about."471 Nor was the Kál the only native paper to launch an attack on Christianity. In Bengal, the Persian journal Rosnama-i-Mukaddas Hablul Mateen uttered disparagingly, "If these be the war tactics of a Christian people, enlightened by the civilisation of the West, it does not look well for Europeans to express contempt and displeasure for what a few half-educated and half-civilised Chinese have done." 472 The Bangabandhu stated simply: "Christian morality is verily a puzzle to us." ${ }^{473}$ Whereas the Irish press insisted that Britain was politically and morally at fault for launching a war against another Christian nation, many in the Indian press indicted the Christian religion as much as the nation.

The aftermath of the Battle of Tweebosch would provide the native press in India with an unprecedented opportunity to extol the character of the Boers, while demeaning that of their imperial opponents. The battle, which proved disastrous for the British, was notable for the capture of General Paul Methuen at Tweebosch, on 7 March $1902 .{ }^{474}$ The

\footnotetext{
${ }^{470}$ Ibid.

471 Ibid.

${ }^{472}$ Rosnama-i-Mukaddas Hablul Mateen, 24 December 1900.

${ }^{473}$ Bangabandhu, 3 March 1900.

${ }^{474}$ During the battle, twelve hundred British troops were overcome by General Koos De la Rey and his men, and Methuen suffered a debilitating wound in the thigh. Pakenham notes that Methuen was "the first
} 
subsequent unexpected release of the badly-injured Lord Methuen by the Boer General De la Rey prompted an outpouring of praise by the native press, which lauded the Boers' act of rare wartime benevolence. In Bengal, the Sanjivani cheered, "Delaroy's [sic] magnanimity has astonished the whole civilised world. The generosity of the Boers has won the admiration of all. ${ }^{, 475}$ In Bombay, the Shri Sayaji Vijay also extolled the "splendid magnanimity" of the Boers, but noted pointedly, "What a contrast between their conduct and that of the British!" ${ }^{\prime 76}$ Nationalist editors, once overwhelmingly loyal to Britain, found themselves increasingly alienated from an Empire that engaged in dishonorable conduct.

Thus, the Kál—after dutifully crediting the Boers for their generosity—reserved most of its commentary for the acts of the British, sniping that the Boers' gesture was "in striking contrast with the pusillanimity and ingratitude of the English who have not only not released a single Boer prisoner, but have, on the contrary, ruthlessly executed some of the Boer Generals on one pretext or another." ${ }^{477}$ Tilak's English-language paper, the Mahrátta, informed its readers that Methuen's capture was the result of "successful military strategy by the Boers," but noted that his release "was still a better strategy.,"478 Its sister paper, the vernacular Kesari, declared, "If after this generous act the English should still adhere to their determination not to make peace with the Boers unless they and last British general to be captured by the Boers during the campaign.” Pakenham, 583. Notably, Methuen had served as Press Censor in India in 1897.

${ }^{475}$ Sanjivani, 20 March 1902

${ }^{476}$ Shri Sayaji Vijay, 20 March 1902.

${ }^{477}$ Kál, 21 March 1902.

${ }^{478}$ Mahrátta, 23 March 1902. 
consented to give up their independence completely, then they must be regarded as the most illiberal, selfish and ambitious nation in the world."479 The lesson was clear: the British, whom the Indians had long admired, were wanting in the humanity and moral conscience of which they boasted to their imperial subjects. Perhaps the time had come to reevaluate the relationship between the Empire and the inhabitants of the subcontinent.

In the final months of the war, the British Government discovered that the native press still had one more weapon in its anti-imperialist arsenal: the treatment of the Indians in South Africa. The Kesari informed its readers, "The ill-treatment of Indian settlers in the Transvaal was mentioned by Mr. Chamberlain as one of the reasons for declaring war with the Boers. The Indian settlers, therefore, naturally expected that their grievances would soon be redressed." ${ }^{480}$ The paper was quick to point out the flaw in this optimistic thinking, noting indignantly, "But far from this expectation being realized, we find that the British colonials in South Africa have formed a league with a view to expel all Indian immigrants from the country."481 Kept apprised of the penal laws by former stretcher-bearer Mohandas K. Gandhi, Bombay papers related details of the harsh restrictions to their readers. The Mahrátta reported that "soon after Pretoria came under British control, an Indian was fined $£ 10$ for walking on the foot-path," while the Kaiser-iHind denounced "the many stupid disabilities which the Government has created there to shut out Indians." 482 The fact that Indian immigrants had actually supported the war

\footnotetext{
${ }^{479}$ Kesari, 18 March 1902.

${ }^{480}$ Kesari, 18 March 1902.

${ }^{481}$ Ibid.
} 
effort, serving as stretcher-bearers throughout the conflict, aroused further resentment on their behalf. In the face of such loyalty, how could the British abandon their Indian subjects in such a callous manner?

As it had many times during the course of the conflict, the nationalist press exploited every slip of the British Government, using each political and military gaffe to encourage its readers to depend on themselves — and not the Empire — for their salvation. Lamenting the thought that "not a spark of humanity is left in the white settlers in South Africa," the Jam-e-Jamshed reported, "We are told that memorial medals will be presented on the Coronation Day to all school-going children of the white settlers in Natal, their black playmates rigourously excluded from the presentation." ${ }^{483}$ The paper left no doubt what it thought of the policy, stating accusingly, "Such a selfish and mean policy only casts a slur on British prestige and tends to widen the gulf between the rulers and the ruled in India." $" 484$ The Mahrátta declared, "If India's loyalty is to be requited in this way and if the Indians are to be branded as serfs unworthy of touch, surely the days of broad statesmanship are hopelessly over." ${ }^{, 45}$ Its sister paper, the Kesari, commented acerbically, "The question of providing good wives to British colonists in South Africa is being keenly debated in England; but the question of cancelling the oppressive and barbarous laws passed against the Indian settlers by the Transvaal Government is still

\footnotetext{
${ }^{482}$ Mahrátta, 6 April 1902; Kaiser-i-Hind, 26 January 1902. The Kaiser-i-Hind also informed its readers of the "continuous agitation which Mr. Ghandi (sic), as their leader, has heroically carried on these five years in spite of all the obstacles and of many formidable lions in the path."

${ }^{483}$ Jam-e-Jamshed, 20 May 1902.

${ }^{484}$ Ibid.

${ }^{485}$ Mahrátta, 6 April 1902.
} 
neglected!" ${ }^{486}$ Whereas nationalist journalists had once attacked Boer abuse of Indian immigrants, they now used their publications to criticize British treatment of the immigrants, and to point out to their readership the similarity of British and Boer Indian policy.

Although the Indian press would generally praise the terms of the final treaty between the Boers and the British and were relieved at the rapprochement between the parties, they harbored a litany of grievances about the conduct of the war. Certainly, the papers criticized Britain's motives for engaging in the war and tactics in conducting the war. There were, however, more personal reasons for assailing the Government, including the lack of Indian troops deployed to the Transvaal, the presence of Boer prisoners in India, the mistreatment of Indian immigrants in South Africa, and the fact that the war daily distracted the Empire, preventing it from addressing issues of poverty and devastating famine on the subcontinent. ${ }^{487}$ These factors prompted the press to demand convincing answers from the Government, and to convey to its readers the unsettling impression that the status quo was no longer acceptable.

Significantly, by this moment in time, the native press in India was beginning to better understand the part it could play in disseminating information to the masses. Bal Gangadhar Tilak's vernacular newspaper, the Kesari, was certainly in the vanguard of this movement, and, as the war neared its close, provided what amounted to the most

\footnotetext{
${ }^{486}$ Kesari, 9 April 1902.

${ }^{487}$ The Freeman's Journal was in agreement that the war in South Africa had proved a distraction to Britain fulfilling its imperial obligations, noting, "So much time and money was spent taking life that there was scope for comparatively small expenditure in saving it." The paper accused "that glorified prig" Lord Curzon of attempting to stride into the spotlight and portray himself - and the Government-as saviors, "now that the war is smouldering, though not quenched, and the Government has been floated back to office on a crimson tide." 22 October 1900.
} 
detailed and compelling declaration of the role of the Indian native press. "Twenty years ago," wrote the paper, "the writers of the Press appealed only to the educated classes, taking little account of the uneducated masses who form the bulk of the community. The Kesari, however, struck a new note, and recognised their proper place in national life. ${ }^{, 488}$ The paper elaborated on what it saw as its responsibility to the masses, insisting, "we have always regarded it as a part of our legitimate duty to acquaint the people with the nature of British administration, to point out to them the harm it has done and the measures that we must adopt, individually, collectively, for the removal thereof, to foster public spirit and the spirit of union among the people and to lead them to utilize that the spirit towards the accomplishment of our objects. ${ }^{.489}$ However diplomatic the words may have sounded, the image of a united India whose subjects would work together collectively to obtain their objective was certain to produce uneasiness among Government officials. This warning shot across the bow alerted the Empire to the newfound power of the press.

The Kesari left no doubt about its intentions, or its targeted readership, proclaiming that its writings "are meant not only for Government but also for the people." "490 "Our aim is to impart to our readers our thoughts and even our mental disquietude," Tilak explained, "and if the writings in the Kesari do not accomplish this object, our labours will have been in vain." ${ }^{491}$ The paper was well aware that the Government was displeased with the criticism from the native press. Yet, despite the fact
${ }^{488}$ Kesari, 11 February 1902.
${ }^{489}$ Ibid.
${ }^{490}$ Ibid.
${ }^{491}$ Ibid. 
that Tilak had already been imprisoned under charges of sedition, the editor refused to back down, proclaiming the determination of the native press to soldier on in performance of what it envisioned as its duty. "Our aim is not to deprive any one of his kingdom," avowed the Kesari, "but simply to prepare the people, under the aegis of British rule, for the improvement of their condition, and as long as we have no other end in view we have no reason to be afraid of anybody." ${ }^{492}$ Inherent in that promise was the idea that the press would side with the people against the Empire, if it perceived the necessity for such an action.

The Indian native press had couched its original disapproval of the Boer War in terms of reproach and reproof and, to all appearances, only reluctantly launched outright criticism at Britain and the Empire. Moreover, the editors were constantly aware of the propensity of British officials to accuse vernacular papers of sedition. Thus, more often than not, Indian native journalists wisely disguised their criticism as gentlemanly banter. By contrast, the Irish advanced-nationalists had long rejected out of hand any attempt at subtlety, and had opted, instead, for wholesale condemnation of the conflict, the Government, and the Empire - even before the onset of hostilities. The Irish press clearly realized it had been given a gift, and it intended to parlay that generous offering into Irish independence.

Coverage of the Irish Transvaal Brigade combined with reports of Irish casualties among the imperial forces and harrowing tales of atrocities committed by the British created an indelible impression of a war gone terribly wrong. The work of the Irish advanced-nationalist press played a critical role in keeping the travails in the Transvaal

${ }^{492}$ Ibid. 
front and center in its journals, helping convince the populace of the rightness of the nationalist cause. Oratory from Irish parliamentarians laid out much the same positions, but the masses generally heard about them because their speeches appeared verbatim in the United Irishman, the Freeman's Journal, and their ilk. Whereas John Redmond and John Dillon refuted, rebuffed, and repudiated British policy during the three-year conflict in South Africa, their posturing was largely meant for the ears of the Government. It was only because the Irish nationalist press reprinted and disseminated those speeches and analyzed those positions in the newspaper that the masses became aware of the war of words in Westminster, and by extension, the salient issues of the Transvaal crisis itself.

The continuance of hostilities gave the advanced-nationalist press yet another opportunity to praise the courage and fortitude of the Boers, and to place before the Irish populace an instance of a beleaguered people who refused to submit to their English oppressors. The year 1900 had witnessed the birth of yet another advanced-nationalist journal, with the founding of The Leader by D. P. Moran. Moran, who would become the foremost proponent of an Irish-Ireland reserved exclusively for Irish Catholics, often proved as fond of excoriating the weaknesses of his fellow countrymen as he was of damning British policy in the Transvaal. In an article entitled, "If the Boers Were Irish," Moran informed his readers that "The Transvaal is led by men, and not by ranters and exploded heroes.. ${ }^{, 493}$ In the editor's estimation, the Irish predilection for sentiment would keep them forever harnessed to the past, incapable of building an Ireland for the Irish. "Boers have no sentimentality in them," Moran declared, before conceding, "We have

\footnotetext{
493 "If the Boers Were Irish," The Leader, 15 September 1900. Cited in Donal Lowry, The South African War Reappraised (Manchester: Manchester University Press, 2000), 224.
} 
little else."494 Elaborating on those characteristics which separated the Boers from the Irish, Moran identified the former's experience as riflemen, but also the aggressive "business-like" approach they took to acquiring the military might to combat British forces. $^{495}$

During the summer of 1900 , much of the Irish nationalist press had turned its attention to the Boxer Rebellion, eyeing another chance to portray Britain as an aggressor. The war in China, however, yielded fewer opportunities to single out the British Empire as the villain, given the involvement of seven other European nations. Moreover, the press was able to uncover much less common ground between the Irish and the Chinese rebels, given the disparities in race and religion - the very factors that so preoccupied the native press in India. Finally, unlike the Boer War, the Boxer Rebellion was not a conflict for which Britain recruited Irish soldiers, or one in which the Irish lined up to fight against the British; therefore, the press could not exploit the tragic deaths of countrymen. Thus, journalists in Ireland welcomed the opportunity to return to covering the more recognizable South African battlefield, particularly one which had already yielded such rich material for skewering the British.

In India, the sheer size and population of the subcontinent meant that the volume of papers far exceeded those circulating in Ireland. Moreover, despite the obvious leadership of figures such as Tilak and Paranjape in Bombay and Banerjea in Bengal, vocal and persistent criticism of the Empire was not limited to their newspapers; rather,

\footnotetext{
${ }^{494}$ Cited in Donal McCracken, The Forgotten Protest: Ireland and the Anglo-Boer War. (Belfast: Ulster Historical Foundation, 2003. First published Johannesbuurg and Capetown: Perskor Publishers. 1989). "The Boers, in short, behaved like men," commented McCracken, "the Irish like children."

${ }^{495}$ Ibid.
} 
by the end of the Boer war, Britain found itself besieged by papers in a variety of dialects throughout all five provinces, including strongly worded editorials from the Bengalilanguage Bengalee, the Gujarati-language Jam-e-Jamshed, the Marathi-language Kesari, and the Tamil-language Puduvaimitran. By contrast, in Ireland, the most relentless criticism came from the mouthpieces of just a handful of nationalist editors, with Arthur Griffith's United Irishman and the Freeman's Journal — the mouthpiece of the Irish Parliamentary Party and normally more moderate in its criticism—being the most ardent and aggressive. Griffith seized upon the fact that only a small number of Boers had surrendered to the British forces to offer an interpretation of how the Boers viewed the English, cheerily listing the battles in which the Boers had bested their imperial opponents. "Unhappily the Boers have been misled by Spion Kop, Stormberg, Magersfontein, and a few other encounters into believing that the British soldier is not Achilles redivivus," smirked the United Irishman. ${ }^{496}$ Continuing its mythological analogy, the paper concluded, "They have found that, heroic though Atkins be in his own estimation, he has heels all over his body." ${ }^{497}$ In the absence of new British losses to relish, Arthur Griffith's paper looked for any occurrence in the Transvaal that might enable it to show Britain in a bad light. ${ }^{498}$

\footnotetext{
496 “Cows Far Off," United Irishman, 4 August 1900.

${ }^{497}$ Ibid.

${ }^{498}$ Upon learning that a delegation of Boers had made its way to the United States, to petition President McKinley to intercede with the British on behalf of the South African republics, the United Irishman informed its readers that the journey had been futile. In fact, the American president "discouraged every hope that the United States Government would raise a finger to stave off the crushing of the Republics." The paper reserved most of its scorn for the Republican Party, explaining, "In foisting the war with Spain and the subsequent annexation of the Philippines on the American people, they wrapped themselves up in the coils of Imperialism, and could, therefore, hardly throw stones at England for pursuing a like course." This was one of the paper's rare references to American imperialism and the War in the Philippines and, true to form, served not so much to indict the United States or demonstrate support for residents of the
} 
The United Irishman also transformed its coverage of the hanging of the "heroic" Lieutenant Hans Cordua - the German would-be assassin of Lord Roberts — into a wholesale condemnation of British policy in the Transvaal. The paper charged, "Up to this the English had contented themselves in the Transvaal with finishing off the wounded on the field of battle, permitting the wives of the Boers to be outraged by the Kaffirs, expelling families, burning farms, and devastating the crops. Their ferocity was not yet satisfied; they had need of a judicial murder." ${ }^{499}$ Certainly, the ferocity of the Irish advanced-nationalist press was not satisfied. The more opportunities journalists could seize to accuse the British Government of murder, slaughter, tyranny, and inhumanity, the more readily they could make the case to their readers that a separation from the Empire was not merely advisable, but essential.

Griffith and his colleagues went to great pains to ferret out any aspect of the war which could help demonize the British and their prosecution of the war. Not content to excoriate Britain's conduct of the war, the article segued into a forceful attack on the figure of the ailing Queen Victoria, charging "She has made Ireland a vast graveyard; India an immense charnel house. And now the turn of the Boer peoples is come."500 Warming to his theme, Griffith wondered if God would "grant her the favour of closing her ears so that in the hour of agony she will not be troubled by the groaning of the

Philippines, but to invoke the devastation wrought by British imperialism. The United Irishman held out hope that if Bryan were to win the upcoming election, his first duty will be to aid President Kruger by demanding the preservation of the Independence of the Boer Republics." "The Boer Peace Delegates," United Irishman, 17 July 1900.

499 "A Martyr for Freedom," United Irishman, 1 September 1900. Lieutenant Cordua was a native of Hamburg who had joined the Boer fighting forces at the onset of the war. He was convicted by courtmartial of attempting to kidnap and murder Lord Roberts and other British officers, and was executed by firing squad on 24 August 1900.

${ }^{500}$ Ibid. 
sufferers?" ${ }^{501}$ In terms of official response to the editorial, it certainly did not help Griffith's case that this was the second United Irishman attack on the monarch within a six-month period, as the paper had vilified the Queen on the occasion of her visit to Dublin in April. ${ }^{502}$ On that occasion, Dublin Castle ordered a raid of the paper's offices and all issues were confiscated and Griffith had informed his readers, with a wink, "Private visits have become quite the thing of late." 503

In India, however, the Madras-based Jámi-ul-Ulúm was surprised to learn that Griffith had merely been sentenced to pay a fine of ten shillings, or serve fourteen days in prison. The Indian paper expressed its wonderment, exclaiming, "Such is the treatment accorded to the Irish, who are (always) in open rebellion." ${ }^{504}$ The Jámi-ul-Ulúm contrasted Griffith's sentence with the eighteen months imprisonment meted out to Tilak in 1897, as well as a similar prison sentence handed down to the editors of the Jámi-ulUlúm and a life sentence being served by the editor of the Pratod, "because he expressed his preference for the Government in Canada to that in India." ${ }^{505}$ This disparate treatment of the Irish and Indian editors was but one instance of the British Government establishing a troubling double standard in how it dealt with criticism emanating from Ireland and the subcontinent. As with the Government's refusal to deploy Indian troops

\footnotetext{
${ }^{501}$ Ibid.

${ }^{502}$ The issue of 7 April had featured a withering attack by Maud Gonne on the "Famine Queen," in which the fiery nationalist had referred to Victoria's soul as "vile and selfish and pitiless."

${ }^{503}$ United Irishman, 14 April 1900.

${ }^{504}$ Jámi-ul-Ulúm, 21 May 1900.

${ }^{505}$ Ibid.
} 
to South Africa, the Indian press was dismayed that Indian loyalty should be repaid with such obvious disdain.

The Jámi-ul-Ulúm would have been pleased to learn that the British Government continued to target Griffith throughout the summer, convinced the editor was publishing articles designed to incite rebellion by Irish soldiers deployed alongside British troops in the Boer War. ${ }^{506}$ A brief glimpse of an advance copy of the issue of 1 September was enough to propel Dublin Castle into action. "One of the definitions of sedition is "to bring into hatred or contempt the Sovereign,"” roared the Chief Secretary, adding, "I cannot conceive any writing more seditious than the article referred to in margin.",507 Deeming the article "a bad case," the Lord Lieutenant of Ireland, George Henry Cadogan, not only issued a warrant demanding that the paper halt publication for six months, but also ordered that the Under-Secretary for Ireland, Sir David Harrel confiscate every available copy of the offending issue of 1 September $1900 .^{508}$ Officials not only seized every copy in Dublin, but also those in every major Irish population center, including newspapers in counties Kerry, Clare, Galway and Mayo, as well as 150 copies in Belfast and fifty-seven in Londonderry — an indication of the widespread circulation of the United Irishman beyond the capital. The pattern of surveillance, seizure, stoppage, and suppression would reoccur throughout the seven-year life of the United Irishman. Warrants to "open and detain" all copies of the paper for a period of six months were

\footnotetext{
${ }^{506}$ Secret memorandum, Chief Secretary’s Office, Police and Crime Division, 31 August 1900. CO 904/159, National Archives, Kew, London.

507 Ibid.

${ }^{508}$ Secret memorandum, Chief Secretary’s Office, Police and Crime Division, 31 August 1900. CO 904/159, File 67, National Archives, Kew, London, England; Secret memorandum, Chief Secretary's Office, Judicial Crime Division, CO 904/159, File 818.
} 
issued on almost a semi-annual basis from September of 1900 until the summer of 1906, appearing first under the signature of Under-Secretary Sir David Harrel and then signed by his successor, Sir Antony MacDonnell.

Arthur Griffith pulled no punches in relating the events surrounding the latest seizure of his publication, announcing, "Last week, for the third time, the ignoble head of a dishonoured family ordered his pimps and uniformed thieves to steal the issue of the United Irishman. ${ }^{, 509}$ The United Irishman revealed that the issue in question had actually been on sale for two days before Dublin Castle sent officials to suppress it, and thus "there were few issues left in the newsagents' shops." ${ }^{510}$ The editor crowed with pride, "In the Irish press there is but one voice the cowardly governors of our country fear, and that voice is ours." ${ }^{511}$ Behind closed doors, officials were compelled to acknowledge the power of Griffith and the advanced-nationalist press to turn public opinion against the British Government.

Deliberately highlighting the division within nationalist ranks, Griffith blasted the Irish Parliamentary Party for not coming to the paper's defense in Westminster, and uttered not only a rebuke of the Government's actions, but also a ringing manifesto of the United Irishman's mission. Proclaimed the editor, "We came into being for the sole purpose of aiding in the destruction of the Empire whose soldiers are today firing the homes of the farmers of the Transvaal and corralling the Hindus that they may perish of hunger the faster. Possibly we may destroy it, or possibly it may destroy us, but

\footnotetext{
${ }^{509}$ United Irishman, 8 September 1900.

${ }^{510}$ United Irishman, 1 September 1900.

${ }^{511}$ Ibid.
} 
assuredly it may not intimidate us. ${ }^{, 512}$ Once again, Griffith connected Ireland's

beleaguered status to that of the Boers in South Africa, and, perhaps as significantly, forged one more link between Irish and Indian subjects of the Empire. With an innate understanding that the Boer War would ultimately be won by the British, Griffith was seeking another example of British oppression that he could present to the readers of the United Irishman. ${ }^{513}$

Whereas Arthur Griffith was certainly the primary instigator of the Irish pro-Boer movement, and the advanced-nationalist United Irishman the most aggressive in its antiBritish stance, the paper was by no means the only Irish paper to mount a sustained campaign of criticism directed at British conduct of the war in South Africa. Taking stock of the conflict at year's end, the nationalist Freeman's Journal made no attempt to disguise its disapproval of the manner in which Britain had conducted the war in South Africa. ${ }^{514}$ The paper ridiculed Britain's multitude of setbacks in the war as the “succession of 'temporary' 'checks,' 'incidents,' and 'mishaps' to which the Boers have subjected the toy soldiers who contemplated a picnic to Pretoria, with the Transvaal

${ }^{512}$ Ibid.

513 Over the years, Dublin Castle grew increasingly incensed by Griffith's propensity to run antirecruitment articles, with secret correspondence showing particular concern over a pamphlet reprinted in the issue of 16 December 1905, in which Griffith charged, "Any man entering her service betrays his own land and goes over to her enemies." Whereas records make clear that Dublin Castle yearned to launch another prosecution against Griffith, it instead held back, fearing, "any proceedings would rather benefit the paper and increase the evil effect caused by the publication than otherwise." Secret memorandum, Chief Secretary's Office, Judicial Crime Division, CO 904/159, File 818.

${ }^{514}$ Although the United Irishman and the Freeman's Journal seemingly marched in lockstep regarding their critical coverage of the Boer War, Arthur Griffith would later excoriate the Freeman in a series of articles appearing between 1915 and 1918 in Nationality, one of Griffith's last papers. See Felix M. Larkin, "Arthur Griffith and the Freeman's Journal," in Irish Journalism before Independence: More a Disease than a Profession (Manchester: Manchester University Press, 2011), 174-185. Larkin suggests that the Freeman's Journal "attracted Griffith's particular disdain because it was the organ of the Irish Parliamentary Party (IPP) at Westminster.” (177) 
mines in the background." ${ }^{, 515}$ Indicative of the close relationship it maintained with Michael Davitt, the Weekly Freeman proudly printed in its pages "The Boer Story of the War," Davitt's decidedly pro-Boer analysis of the conflict. Included in every issue of the Freeman's Journal for a period of months was an "Important Announcement" alerting its readers about what it was calling the "Publication of the Year." 516

Unlike the advanced-nationalist press based in Dublin, the regional papers initially adhered to the optimistic line offered by the British Government, assuring its readers that despite the renewal of hostilities, the Boers could not sustain their resistance and the war would soon be over. As casualties mounted, however, evidence of concern began creeping into the coverage of the war, and the regional press joined those struggling to make sense of contradictory press releases. Thus, in quick succession, the Nenagh News suggested that the British losses contradicted any hope of a speedy termination to the war, the Connaught Telegraph maintained "Brave Boers Still Firm," and the Southern Star declared, "Boers Will Fight to the Death"- even as the Kildare Observer reported that the Boers were short of ammunition, and the Nenagh Guardian related the news that the Boers "have not only lost all hope of success, but are fighting among themselves." ${ }^{517}$ In their slower move to condemn the British, the regional papers more closely resembled the Indian native press than the aggressive advanced-nationalist press based in Dublin, who insistently pressed for full Irish independence.

${ }^{515}$ Freeman's Journal, 24 December 1900.

${ }^{516}$ Freeman's Journal, 8 March 1901, and others.

517 “The Transvaal War,” Nenagh News, 28 July 1900. “The Boer War,” Connaught Telegraph, 11 August 1900; “Transvaal War Incidents," Kildare Observer, 25 August 1900; Nenagh Guardian, 19 September 1900 . 
As with the native Indian papers, the turning point for many journalists in the regional press was Britain's adoption of its brutal new tactics of intimidation, and the ensuing tales of war atrocities perpetrated by imperial forces. By the opening days of 1901, the Anglo-Celt of County Cavan was proclaiming that a "savage order of extermination" had been issued by Lord Kitchener, the Butcher of Khartoum, and declaring, "Many who sighed for the establishment of British supremacy in the Transvaal would now be very glad to get back to the Boer regime." ${ }^{518}$ The cost of the ongoing war to the Irish taxpayer preoccupied the Meath Chronicle, which avowed, "Not even the Jingoes can be satisfied with such disastrous results of their policy," and the Southern Star was forced to conclude, "Though the war in South Africa is still continued with all the severity and cruelty that has been exhibited by the English Government since the commencement of hostilities, we find no indications leading to the conclusion that it is yet drawing to a close." ${ }^{, 519}$ Ultimately, it was Britain's resort to harsh measures that tipped the opinion of Ireland's provincial papers against the Empire.

The Boer War provided the Irish nationalist press with tangible examples of what it characterized as egregious imperial overreach, with the implication being that Britain's aggressive actions in the Transvaal were identical to its treatment of the Irish. In a scathing indictment of British expansionism, Arthur Griffith compared the land grab and subsequent slaughter of Boers in the Transvaal to a cowardly murder committed by a man who lusted after the property of his neighbor and "battered his brains out." 520 The editor

\footnotetext{
518 “No Quarter!” Anglo-Celt, 19 January 1901;” Better under the Boers," Ibid.

519 “The Budget," Meath Chronicle, 4 May 1901; Southern Star, 18 May 1901. By the end of the First World War, both papers would no longer classify themselves as nationalist; they proclaimed themselves advocates of Sinn Féin.
} 
was insistent that proselytes should abandon their support of British Imperialism for two critical reasons. "The first is an Irish reason-it is robbery plus murder," charged Griffith, adding, "The second is an English one-it won't pay. . . The experiment of trying to coin dividends out of Boer blood ruined it., ${ }^{, 521}$ At every instance, Griffith used the South African war to sound the death knell of British Imperialism.

As more evidence surfaced of Britain's resort to increasingly ruthless tactics, the advanced-nationalist press issued its most resounding denunciation of the British cause. Editorials in the Freeman's Journal heightened in intensity of feeling with each new revelation of British military policy. "With a full sense of our responsibility as journalists," the Freeman 's Journal made public Kitchener's orders to give no quarter to Boer prisoners, characterizing the policy as "the suspension of civilised warfare in the ... campaign against the bravest and most honourable soldiery that ever stood up to defend the liberty of a nation." ${ }^{522}$ Noting that the Daily Telegraph and the Standard had called for the "cold blooded murder of prisoners," the paper accused the military of capitulating to the demands "urged months ago by the Jingo Press in its feeble and cowardly rage." The Freeman's Journal labeled the conflict "a war not for freedom but for gold," and blasted a Government which seemed more concerned about an imminent attack on the mines than it did about the loss of thousands of Irish and Scottish soldiers, which it bore "with philosophic resignation." ${ }^{, 524}$ Reporting on Irish Parliamentarian John Dillon's

\footnotetext{
520 “British Imperialism,” United Irishman, 2 February 1901.

521 Ibid.

522 “Lord Kitchener's War Methods,” Freeman's Journal, 15 January 1901.

523 “Murder in South Africa,” Freeman's Journal, 18 January 1901.
} 
"scathing indictment of British savagery in South Africa," during the previous evening's session in Westminster, the Freeman's Journal, the Party's official organ, praised the performance of Dillon, who "thrust aside the screen of official falsehood and subterfuge with which it was sought to hide their naked atrocity from the gaze of a horrified public." 525 Appalled by news of British internment of women and children, the paper departed from its previously more measured criticism and launched its most ferocious attack on the Empire — aligning the Freeman's Journal, at least temporarily—with the criticisms offered by the advanced-nationalist press.

By the summer of 1901, even much of the regional press had abandoned their blind acceptance of British war releases. The Southern Star was ridiculing the work of the paid military censor who made a practice of depicting the Boers in the worst possible light and, "who carefully edits every page of manuscript until he satisfies himself that the blundering of the Generals is carefully concealed." ${ }^{, 526}$ Headlines such as the Anglo-Celt's "The Truth Leaks Out" and the Connaught Telegraph's "The War that is (not) Over" were designed to inform readers that the British were not to be trusted, and that the truth could only be found in the columns of the nationalist-leaning Irish press. ${ }^{527}$ The reality, however, of just how far the regional press had distanced itself from the British Government became clear only when word of British military atrocities broke through the censors' barriers. In response to Lord Chamberlain's proclamation that "No war in the

\footnotetext{
${ }^{524}$ Freeman's Journal, 4 February 1901.

525 “British Savagery in South Africa," Freeman's Journal, 27 February 1901.

526 “The Press Censor,” Southern Star, 17 August 1901.

${ }^{527}$ Anglo-Celt, 9 November 1901; Connaught Telegraph, 15 March 1902.
} 
history of the world has ever been conducted with greater humanity," the Southern Star righteously demanded, “In heaven's name, what are the Colonial Secretary's ideas of humanity? Murder, pillage, loot, fire, confiscation, and outrage, and all the unspeakable horrors of a ferocious soldiery — are these Mr. Chamberlain's principles of humanity, for these constitute the policy of the war." ${ }^{258}$ The Government had grown accustomed to unpatriotic outbursts from the United Irishman and Freeman's Journal in Dublin, but it did not expect such a wholesale rejection of its war policy from West Cork.

Indeed, as details of conditions in the concentration camps began to surface, the sad truth of the situation did far more damage to Britain's liberal image than any fabrication the advanced-nationalist press could have invented. At the same time that the Government was extolling the sanitary conditions in which the families dwelled, the United Irishman was informing its readers that "the water of the Modder River full of typhic germs has been served to the Boer families in the camps of concentration" and that only one doctor was present in the camp at Johannesburg, "though epics of measles and typhus have swept whole families." ${ }^{529}$ It did not help the British cause that officials were desperately attempting to put a positive spin on such cavalier treatment of women and children.

In November, the issue of race once again intruded into coverage of the war. The United Irishman furnished its readers with official Government figures on the concentration camps as of September, which reported the deaths of more than 2400 white internees. The British Government did not furnish figures for the deaths of non-whites,

\footnotetext{
528 "Playing to the Gallery," Southern Star, 2 November 1901.

529 “English Atrocities," United Irishman, 3 August 1901.
} 
and, significantly, the Irish advanced-nationalist press did not seem to notice the omission-demonstrating the fears of the Indian native press that white men only cared about the lives and deaths of other whites. The United Irishman predictably condemned the British Government for the policy, but it also indicted the British people, whose failure to protest indicated to the paper their tacit approval. "They are not shocked at it, they are doing nothing to prevent it," stated the United Irishman. ${ }^{530}$

Claiming the camps were an act of war, the paper charged, "The English people are literally making war upon women and children wholesale." In a more unexpected move, however, the United Irishman also accused the Irish, themselves, of complicity, arguing that Irish soldiers were engaged in fighting in South Africa, Irish money was helping to fund the war, and the Irish people remained silent on the subject of the camps. In one of its more fascinating accusations, the article found Irish newspapers culpable of being "more anxious to score against English politicians than to preserve our National honour." 531 Given that the advanced-nationalist press previously had been going to great lengths to illustrate that the British and the Irish were not cut from the same moral cloth, this seemed a rather damning admission. Within a week, however, the paper had returned to form, blaming the British alone for the horrors in the camps, and printing a poem entitled "Kitchener," in which the opening salvo read:

"Hail, conqueror of babies

Thou Kitchener of a king.,, 532

\footnotetext{
${ }^{530}$ Ibid.

531 Ibid.

532 “Kitchener," Freeman's Journal, 9 November 1901. Satiric poems were much in style in the Irish nationalist press. After Kitchener wired a cable detailing the capture of a Boer camp that apparently consisted exclusively of women tending cows, the Connaught Telegraph printed a parody of the Alfred,
} 
Both the Freeman's Journal and the United Irishman continued to harp on the lack of trustworthy news emanating from official sources. "Owing to the obvious falsity of most of the news that is now allowed to come through from the seat of war in South Africa, and the deliberate inadequacy of Lord Kitchener's official despatches," claimed the Freeman's Journal, "it is almost impossible to gather anything like a clear idea of what is going on in the Republics. ${ }^{, 533}$ Unable to obtain from British sources what it considered reliable news, the United Irishman regularly poached articles from other European organs, and sought out firsthand reports from Europeans on the ground in South Africa. Notably, the paper reprinted a letter from a Frenchman in Pretoria, who provided evidence of farm-burnings, as well as the "inhuman and unchristian treatment" meted out to women and children in the concentration camps. ${ }^{534}$ The letter estimated that one half of the children in the camps perished, and that "six hundred and forty-one children out of every thousand perish monthly." ${ }^{535}$ The death of these innocents outraged world opinion and did more to incur anti-British sentiment than any other event in the war As such, it provided Indian and Irish nationalist journalists with the most damning and potent ammunition to date.

By the autumn of 1901, the Freeman's Journal had figuratively thrown up its hands, seemingly unable to convey to its readers the full scope of the war's horror: "In

Lord Tennyson poem "The Charge of the Light Brigade." Among many other indignities visited on the classic poem, the writer amended the line "Into the valley of death rode the six hundred" to read "'Into the valley of cows rode the six hundred" and altered "Cannon to right of them / Cannon to left of them" to read "Women to right of them / Women to left of them." "Charge of the Light Brigade: Adapted to the British Army Records in South Africa," Connaught Telegraph, 12 April 1902.

\footnotetext{
533 “The War," Freeman's Journal, 4 March 1901.

534 “Foreign Notes, United Irishman, 28 September 1901.

${ }^{535}$ Ibid. Post-war British figures estimated that one quarter of the Boer inmates perished in the camps.
} 
good truth, the elements of farce and tragedy are so blended in this preposterous war that one hardly knows whether to laugh or cry over it. It is advancing backwards." ${ }^{536}$ The paper despaired, wondering if Britain would ever stumble upon an efficient tactic for bringing the war to a satisfactory close. "Arson won't end the war, nor murder, nor wholesale infanticide, nor warlike proclamations. What else is left?"537 By enumerating the dishonorable strategies allegedly undertaken by the British, the paper once again made clear to its readers that the Empire had relinquished the moral high ground to which it had long laid claim. Left unspoken was the implication that Ireland needed to distance itself from any nation that chose to engage in such heavy-handed conduct against a people who were desperately fighting for their homeland.

Like Irish parliamentarian John Redmond, the Freeman's Journal refuted the charges leveled by Englishmen that Ireland sympathized with the Boers purely out of hatred for all things British. "There may be something in that, here and there," conceded the paper, before proclaiming, "we are on the side of the Boers, not because we hate or dislike England, but because we are profoundly convinced that the Boer cause is a just one. ${ }^{, 538}$ To bolster its position, the advanced-nationalist press took pains to illustrate to their readers that the European Powers were demonstrably in agreement with Ireland's view of the Boers and the British. Even the Freeman's Journal noted that Frankfurt-onMain was but the latest German city to record its disapproval of the Boer War, hosting a protest meeting attended by thousands. Given the growing rivalry between Germany and

\footnotetext{
536 “War by Proclamation,” Freeman's Journal, 17 October 1901.

${ }^{537}$ Ibid.

538 “The War Debate," Freeman's Journal, 21 January 1902.
} 
Britain, Irish nationalists took a special delight in regaling their readers with German criticism of the Empire. The paper shared the details of the assembly, including the fact that the guest speaker was none other than the nephew of the Boer General Christian de Wet. ${ }^{539}$ The United Irishman informed its audience that the annual celebration of Bastille Day "was made the occasion for a magnificent pro-Boer and anti-English demonstration." "540 The paper characterized Britain as "the most deadly enemy of France, as well as of liberty," implying that Britain's actions had left it isolated, and that it was properly reviled by all right-thinking nations and peoples as the enemy of freedom. Two months later, the United Irishman gleefully shared La Patrie's estimation of new British military tactics. The French paper denounced Britain's new strategy, saying, "their new plan surpasses its predecessors in ignorance of military tactics and (if the word is not too strong) in insanity." ${ }^{541}$ These critiques of British tactics bolstered the Irish depiction of imperial conduct as so aberrant it had alienated the other European powers.

Yet, even as Britain's scorched earth policy was taking its toll in the Transvaal, and thousands of women and children were perishing in the concentration camps, it is clear that many in the Irish press had begun to turn their attention away from Britain's martial adventures in South Africa, and toward a fuller discussion of the path to Irish independence. The war had served the advanced-nationalist press admirably, enabling it to offer endless incentives to its readership to move out from under British stewardship and stake a claim to Irish self-reliance. Indeed, James Connolly, writer for the socialist

\footnotetext{
539 "German Protest Against the War," Freeman's Journal, 6 February 1901/

540 "France and England," United Irishman, 20 July 1901.

${ }^{541}$ England's New Tactics," United Irishman, 10 August 1901.
} 
Workers' Republic, was silent on the issue of the Boer War throughout its final years, instead focusing on improving the lot of Ireland's workers and reserving his scorn not for the military, but for capitalists. In September of 1900, Arthur Griffith had advised his readers of a new organization, Cumann na nGaedheal - the Society of Gaels - which the editor had founded in an effort to establish common cause between the disparate nationalist groups in Ireland. Articles on the Irish language, Irish education, Irish music, Irish literature, and Irish industries began to displace the heretofore rabid coverage of the war in the Transvaal. In the United Irishman, caustic reporting on the conflict was now more often than not relegated to a few paragraphs under "Foreign Notes," while a regular column on "The National Movement" was instituted, and the paper now made a practice of printing at least one article wholly in Irish. Once obsessed by Britain's misadventures overseas and doing further damage to the Empire's already vulnerable reputation, the advanced-nationalist press now began to turn inward - focusing its attention on the domestic programs that it hoped would prove Ireland's ability to stand alone.

The press, however, also fully understood that it would be some time before Ireland could effect a break from the Empire, and journalists intended to use the remaining time to their advantage. As the war entered its final months, the Irish nationalist press could not resist a few well-timed parting shots, returning once more to their disparagement of the British prosecution of the war. "The debate which took place last evening in the House of Commons on the war," proclaimed the Freeman's Journal, "showed that the Government is determined to continue both the cruelty and stupidity of its policy and that the Liberal opposition is afraid to challenge it." ${ }^{542}$ Echoing the rhetoric

${ }^{542}$ Freeman's Journal, 21 January 1902. 
of the Irish Parliamentary Party, the paper staked out its most intransigent position to date, declaring, "Certainly, it is impossible now to conceive that Ireland could, under any circumstances, or for any consideration, give one ounce of her political influence, whatever it may be worth, in favour of the prosecution of a war which to the majority of the people seems to be the most cruel, wanton, unjustifiable attack by a great Empire on a free little nation the world in modern times has ever witnessed." ${ }^{543}$ The war in South Africa had transformed the rhetoric of the Freeman's Journal, until it now sounded as unforgiving and uncompromising as the criticism emanating from the pen of Arthur Griffith or James Connolly.

Despite its disingenuous protestation that it did not harbor scorn for all things British, the Freeman's Journal clearly took pleasure in ridiculing the performance of the British army. In its post mortem on the war, the paper lauded the tactics of the Boer scouts, "who were so well posted that if a British column or convoy moved from any point, all the commandoes within seventy miles knew it the same day." ${ }^{544}$ Contrasting Boer strategy with the ineptitude of British generals, the Freeman's Journal commented wryly, "What a happy thing it would be for the British war office if it could get some of the Boer leaders to teach it how to organize an intelligence department." ${ }^{\text {,55 }}$ The paper was particularly waggish in noting that whereas the House of Commons had declared that less than 10,000 Boers remained in the field at the end of the war, over 16,000 had already come in. The paper could not resist one more jibe at the expense of the British:

\footnotetext{
${ }^{543}$ Ibid.

${ }^{544}$ Freeman's Journal, 17 June 1902.

${ }^{545}$ Ibid.
} 
"The War Office was in the dark when it began the war, and it was in the dark when it finished it. ${ }^{546}$ The United Irishman greeted the end of the war with its own artful repudiation of the British Empire. Rather than congratulate Britain on a victory, the paper referred to the outcome of the conflict as a "temporary escape from annihilation as an Imperial power at the hands of ... 'Peasant Republicans.",547 The United Irishman cheerfully predicted the demise of the British Empire, citing its "worship of luxury," "dislike and inability to face facts," and "hysteria" as three irrefutable and historically accepted signs that it was headed for a downfall. ${ }^{548}$ As ever, there was no attempt to disguise the fact Griffith and his fellow advanced-nationalists were implacable foes of Britain and the Empire.

The three-year Boer war did not materially change the attitudes or the opinions of the Irish advanced-nationalist press. Irish opinion was firmly pro-Boer and against Britain long before the war began. The war was simply the most readily available means of harassing and haranguing Britain at that moment in time. Thus, journalists across the full spectrum of Irish nationalism used the war to focus attention on what they perceived as the inequities and iniquities of the British Empire. By portraying the Boers as oppressed freedom fighters desperately attempting to defend their homeland, the United Irishman, Freeman's Journal, Leader, Worker's Republic and other nationalist organs underscored the link between Ireland and the Transvaal, and transformed the Boer struggle into an Irish cause. The fact that Britain's prosecution of the war earned it the

\footnotetext{
546 Ibid.

547 “Foreign Notes: Hands across the Sea,” United Irishman, 21 June 1902.

548 Ibid.
} 
disapproval of the other European Powers and precipitated a vertiginous drop in the country's prestige was a felicitous outcome. Given Britain's eroded standing at war's end, the Irish advanced-nationalist press was reinvigorated, knowing that Britain's treatment of the Boers would focus new attention on Britain's relations with Ireland. Most importantly, the war gave impetus to the burgeoning nationalist movement, as the press characterized Britain's prosecution of the war as driven by greed and self-interestleaving readers with the unshakeable impression that Britain would never do for Ireland what Ireland could do for itself.

The native press in India and the advanced-nationalist press in Ireland initially approached the Boer War from different perspectives and with different objectivescriteria which dictated the form and content of their coverage. Throughout the protracted war in South Africa, the relentless barrage of scorn and disdain directed from Irish editors at Britain and the Empire became de rigueur - a three-year onslaught that was wholly unsurprising in both its content and embittered tone. By the end of the first month of hostilities, journalists had established their modus operandi: attack, reload, and fire again with unflinching commentary. Thus, when the papers attempted to draw attention to the real horrors of Britain's scorched earth policy and the implementation of internment camps, there was no discernible difference in the level of dramatics.

Yet, if Arthur Griffith and his fellow advanced-nationalists chose to sing their anti-Imperialist rhetoric at full volume, the criticism of Tilak and the Indian native press had been offered sotto voce during the first phase of the war, making its subsequent rise to a full-throated crescendo startling in both its volume and intensity. The war afforded the Indian press an opportunity to air the long-held resentment felt by much of the 
subcontinent - the uneasy sense that India's problems would never ascend to a place of prominence on the Empire's agenda. The Irish advanced-nationalist press was heartily proactive in its approach to the war. Journalists in Ireland deliberately, knowingly used the conflict to give impetus to a nationalist movement. By contrast, the Indian native press was reactive. Whereas it certainly harbored nationalist ambitions before the war, it would not have acted on them as doggedly, were it not for the crisis in the Transvaal that placed in stark relief the subservient relationship of India to the Empire.

If the goal of the press in both countries was not only to reach the masses, but also to persuade them to embrace the nationalist movement, the Boer War provided journalists with a seemingly unending supply of imperialist arrogance, swagger, and callous disregard for Britain's subjects. The British Government had sought to seize the gold mines in the Transvaal. Instead, the Indian and Irish nationalist press mined the war for evidence of avarice and tyranny, painting a portrait of imperial hubris that would prove indelible and enduring. The press had focused on the horrors of an external conflict to grab the attention of its audience. The time had now come to turn inward, to hold the mirror up to readers, and convince them that the resources existed within their own borders to solve their most pressing national problems. The state of dependency on the imperial monolith must end. The era of self-reliance was about to begin —and it was the nationalist press that would ensure that the watchwords of this new age would not be subjugation and submission, but Swadeshi and Sinn Féin. 


\section{"A Common Enemy, A Common Purpose": War and Alliance}

The torpedoes sliced through the water at midnight, striking the Poltava, the Askold, and crippling two pre-dreadnought battleships outside the bay of Port Arthur. ${ }^{549}$ The Japanese fleet sailed on, launching its next strike at noon, engaging a Russian enemy that began the day disorganized and ended demoralized, after less than sixty minutes of fighting. There had been no warning, no declaration of war. The opening salvos of the Russo-Japanese War set the Russians back on their heels—a position from which they never recovered. "Everything went off as planned," cabled Admiral Togo. ${ }^{550}$ The telegram was meant for Japanese eyes only, but news of the humiliating Russian defeat swept rapidly across Asia and Europe, unsettling Western governments, even as it exhilarated Asian observers. While European nations had been busily building their empires, cementing alliances, and eyeing each other with increasing suspicion, a small Asian nation had been stealing a march on the Russian bear.

In Ireland and India, nationalist journalists watched in fascination, as Britain and its continental allies promptly took sides, all the while loudly proclaiming their neutrality. The Russo-Japanese War was the third imperial conflict of the new century, coming on the heels of the Boxer Rebellion and the Boer War. Those conflicts had proven not

\footnotetext{
${ }^{549}$ Pre-dreadnoughts, produced between the 1880s and 1905, were built of steel, to replace the existing ironclad battleships.

${ }^{550}$ Admiral Togo's official report of the attack on Port Arthur, 10 February 1904. Internet; available at http://www.russojapanesewar.com/togo-aar1.html; accessed on 14 February 2013. The fact that Russia was taken by surprise is, in itself, surprising, given that the subject of the 1902-1903 war games was "War between Russia and Japan in 1905." Despite the fact that a surprise attack by the "Japanese" had failed to defeat the Russian fleet at that time, officials lamented the "insufficiency of our naval forces in the Pacific," and predicted the "probability of a sudden declaration of war." Source: "War Games played at the Nicholas Naval academy, St. Petersburg" in Far Eastern Staff Plans of Naval Operations, 1901-3. Internet; available at http://www.russojapanesewar.com/russ-game.html; accessed on 14 February 2013.
} 
merely instrumental in advancing the Irish and Indian nationalist agendas: they were essential to the process. Using Britain's conduct of the wars as material evidence, the nationalist press in India and Ireland, and, in particular, the Irish advanced-nationalist press sought to illustrate the arrogance of the British Empire as it zealously pursued its expansionist agenda. By underscoring the exploitation of manpower and natural resources and emphasizing what it perceived as the callous disregard of public opinion in Ireland and India, nationalist journalists hoped to establish the necessity of selfgovernment and self-reliance. Thus, Britain's imperial wars played an active role in laying the groundwork for the Indian Swadeshi movement and Irish Sinn Féin policy. In turn, these campaigns of self-reliance would deepen and entrench attitudes toward the British Empire that would evince themselves at the outset of World War I. In both cases, it was the nationalist press in Ireland and India that shaped and formed the debate. Not only did the newspapers aggressively disseminate knowledge of the movements and promote the platforms of Sinn Féin and Swadeshi, but in at least one case - that of Arthur Griffith—an editor was solely responsible for devising the basic tenets of the program. No amount of public speeches could have transmitted word to the masses of the new movements with the same rapidity as the press.

Although the time was fast approaching when nationalist journalists would turn their attention to the construction of domestic programs, they would continue to remain vigilant about reporting any international developments that could lend weight to the nationalist cause. Coverage of Britain's interaction with the Boxers and the Boers had served to convince readers that the hopes and desires of subjects in Ireland and India were of secondary interest to the imperial policy-makers residing in London, Dublin 
Castle, and Calcutta. ${ }^{551}$ Thus, any aspirations to nationhood would reach fruition only through the efforts of Irish and Indian subjects, themselves. Accordingly, the years between the end of the Boer War and the outbreak of World War I prompted nationalists in both countries to search for ways in which to invigorate a nationalist movement which had been proceeding only in fits and starts.

\section{War in the East}

Whereas the years immediately following the close of the Boer War brought a period of relative peace for the British Empire-with no major deployment of military forces - the opening decade of the twentieth century witnessed several key seismic events capable of altering the imperial landscape. Looking for issues that would support their own agendas, the nationalist press in Ireland and India directed their critical gaze at political hotspots around the world. Although Britain managed to remain free of any significant foreign entanglements, this did not stop the nationalist press from linking global events in Asia, Africa, and continental Europe to the political and military policies of the British Empire. Nationalist editors were determined to exploit to their advantage any foreign events which could place Britain in an unflattering light.

Accordingly, the timely onset of the Russo-Japanese War afforded journalists ample opportunity to hone their anti-imperialist rhetoric. In 1904, Russia's imperial designs on Korea and Manchuria had provoked an angry response from Japan. An overconfident Russia adopted a hard line during negotiations — convinced its military

\footnotetext{
${ }^{551}$ In a move unpopular with the citizens of Bengal, British officials moved the capital of India from Calcutta to Delhi on 12 December 1911.
} 
could easily overpower any Japanese resistance. Reacting to Russian intransigence, Japanese forces launched their surprise attack on the Russian fleet at Port Arthur and proceeded to stun not only the Russians, but also all of Europe and Asia, with their discipline and efficiency. Within a year, resounding victories by Japanese ground and naval forces would prompt the intervention of President Theodore Roosevelt. The outcome not only delivered a crushing blow to Russia, but also provided a solid foundation for the beginning of Japan's own empire. Just as the Boers' victories at the onset of the South African War had shaken Britain's confidence in its military might, so too the successful Japanese assault would wreak havoc with accepted international hierarchy. No longer would assumptions of Western superiority be a foregone conclusion.

If Irish and Indian coverage of imperial wars in Asia and Africa had already revealed critical differences in their attitudes toward the British Empire, the RussoJapanese War would produce an unprecedented polarization between the advancednationalist press in Ireland and the nationalist press on the subcontinent. Britain, while proclaiming its neutrality, had voiced its distrust of Russia. That suspicion was enough to determine Ireland's pro-Russian position for the course of the war. "Now, it is our interest to see England's downfall," proclaimed the United Irishman, and our concern to extricate ourselves from her ruin. ${ }^{, 52}$ The paper reveled in the notion that Irish nationalists had it within their power, referring to England, "to foil her designs and frustrate her schemes, of regaining her world influence. ${ }^{, 53}$ Even without the direct

\footnotetext{
${ }^{552}$ United Irishman, 5 March 1904.

${ }^{553}$ Ibid.
} 
involvement of Britain in the hostilities, the advanced-nationalist Irish journalists were determined to ensure that the conflict reflected poorly on the British Empire.

Yet there was a realization that the people of Ireland might not take an active interest in a conflict between Russia and Japan. "Blinded by the narrowness of our political training," queried the United Irishman, "how little beyond curiosity and speculation do the events of the present moment in the Far East excite in Ireland?"554 The paper attempted to lay out a rationale for Ireland to follow events half way around the world. Although acknowledging how tempting it was to despise the Japanese for what the paper referred to as arrogance, the United Irishman urged its readers to remember that Japan was "but the catspaw of the moment of circumstances, and that these circumstances are the insidious creation of England and England in America." 555 Indeed, the Southern Star went so far as to laud the Japanese people, asserting that their advancement "in the paths of civilsation, power and progress has been one of the most wonderful developments in National growth which the past century has witnessed." ${ }^{556}$ According to the paper, Japan's meteoric rise took on even more historical significance, given that only a few years previously, it was only an "obscure island in the Far East, inhabited by a small race of Yellow People." ${ }^{557}$ Such characterization of the Japanese people recalled earlier Irish denigration of the Chinese people as embodying "The Yellow Peril" and demonstrated the racism that still permeated the Irish nationalist press.

\footnotetext{
${ }^{554}$ Ibid.

${ }^{555}$ Ibid.

556 “The Rising Sun,” Southern Star, 20 February 1904.

${ }^{557}$ Ibid.
} 
By comparison to the Boer War, in which the combatants had all been white and Christian — and Irish soldiers had played an integral role — convincing the reader of the import of the Russo-Japanese conflict was destined to be a hard sell, and one which would be difficult to sustain. For much of the war, coverage reverted to the Irish press model created during the Boxer Rebellion, with many papers simply reprinting whatever news the cable services had assembled. There were occasional attempts to cover the war from a unique angle, with the Donegal News offering a primer in Japanese pronunciation, entitled "Geographical Jawbreakers," while the Freeman's Journal helpfully promoted a new article in Scribner's Magazine which promised to provide a portrait of the war from the Russian side. ${ }^{558}$ This publication, the paper seemed to suggest, was a matter of great import, given that "most of the accounts dialed up for 'British' consumption are distinctly from the Jap side." ${ }^{, 59}$ In addition to indicting the British press for printing only that information which favored the Japanese cause, the use of the pejorative "Jap" left the reader in no doubt as to the Freeman's Journal's support for the Russian effort.

Equally as important as the pursuit of nationalist goals within Ireland during this period was the spread of Irish nationalism beyond the country's borders. By the turn of the century, the impact of the Irish advanced-nationalist press - and, in particular, Griffith's brand of journalism — was being felt not only within Ireland, itself, but also on the far off shores of America, where so many Irish men, women, and children had emigrated in their flight from the Great Famine (1845-1850). Not all Irish expatriates living in the United States, however, had been chased from Ireland's shores by the

\footnotetext{
558 "Geographical Jawbreakers," Donegal News, 5 March 1904; “By the Way," Freeman's Journal, 13 September 1904.

559 "By the Way," Freeman's Journal, 13 September 1904.
} 
devastating potato blight. Fiery Irish nationalist John Devoy had been exiled to America, after serving five years of a fifteen-year sentence for treason for his part in an 1866 Fenian uprising. In 1903, Devoy founded the New York-based Gaelic-American, whose banner proudly blazoned, "A Journal Devoted to the Cause of Irish Independence, Irish Literature, and the Interest of the Irish Race." From the outset, the Gaelic-American bore the imprint of Irish advanced-nationalism, its outraged output mimicking that of its Dublin counterparts in terms both of content and tone. Unlike its Dublin-based source of inspiration, the United Irishman, however, the Gaelic-American splashed coverage of the Russo-Japanese war on its front page for the duration of the conflict. In addition to accusing the British press of misleading its readers, Devoy's journal indicted the Japanese for "using the tactics of the burglar or the highway robber" in attacking the Russian fleet without an official declaration of war. ${ }^{560}$ No sooner had those first shots been fired in the conflict than the paper revealed its anti-British, pro-Russian proclivities. Specifically, Devoy was convinced that Secretary of State John Hay was taking marching orders from the British Government, and the editor looked to Irish-Americans to quash a proposed alliance between America and Britain. Devoy informed his readers that in the matter of the Russo-Japanese War, "our present Anglophile administration under directions from Downing Street is entirely in accord with Japan." ${ }^{„ 561}$ Peppering its editorials with one of Griffith's pet phrases, the Gaelic-American asserted that the American people had been "humbugged" by what it characterized as the "flood of falsehood," in an effort to paint Russia in the blackest shade of villainy, while

\footnotetext{
560 "First Victory Won by Treachery, “Gaelic-American, 13 February 1904.

${ }^{561}$ Gaelic-American, 19 March 1904.
} 
simultaneously "cultivating sympathy with and admiration for Japan."562 Like Griffith, Devoy's real purpose in defending Russia had less to do with the war and everything to do with irritating the British by maligning their ally in the conflict.

If there remained any doubt that Devoy's Gaelic-American was marching in lockstep with Irish advanced-nationalist papers, the rampant anti-Semitism on view in its coverage of the Russo-Japanese War made the connection unmistakable. In the issue of 14 May, an article entitled "The Jap and the Jew" offered a foray into murky racial theory that revealed more about the writer than the subject. ${ }^{53}$ "Both have in their veins, as illustrated by anthropological research and psychological comparison, the same blood," asserted the author. ${ }^{564}$ The article offered helpful insights, stating that both the Jap and the Jew were not only "capable of violent emotion and fervor," but also "capable of intense fatalism, born in the case of the Jap by a nature naturally cruel and immune to suffering and due in the Jew to a recognition of his lack of physical courage."

The paper assailed the Japanese for reported atrocities, but assiduously refused to blame the Russian government for reported assaults on Jewish subjects, insisting that Jewish antipathy to Russia was "merely a matter of an excited imagination and racial prejudice." $" 566$ The writer concluded, "What Russia does to a Jew within her domains is of no more importance to a brother Jew in America than it is to any other American

\footnotetext{
562،Kuropatkin and Makaroff at Work," Gaelic-American, 2 April 1904.

563 “The Jap and the Jew," Gaelic-American, 14 May 1904.

${ }^{564}$ Ibid.

${ }^{565}$ Ibid.

${ }^{566}$ Ibid.
} 
citizen. At least it should not be." ${ }^{, 567}$ The Gaelic-American's virulent anti-Semitism and pro-Russian coverage of the Russo-Japanese War mimicked the reporting of the conflict in the United Irishman, providing tangible proof that the ideas of Griffith and his fellow anti-imperialists were taking hold among Irish nationalists worldwide. Devoy's paper not only ensconced itself firmly in Russia's corner, but also railed against the possibility of an Anglo-American alliance, warning its readers that America suffered by its association with the British Empire.

While the nationalist press in Ireland and Irish-America offered unflagging support of Russia, purely on the grounds of their pronounced disloyalty to the Empire, by contrast, Indian journalists appeared to fall in line and follow the lead of the Empire. The nationalist press in India spoke out fervently in support of Japan, on the surface appearing to hew to the company line. Evidence reveals, however, that Indian motives for backing the efforts of the Japanese had less to do with unquestioning loyalty and more to do with serving their own interests. If the bloody conflict in South Africa had indicated that a determined people could make life exceedingly difficult for the British forces, Indian papers now pointed to the Russo-Japanese War as a tangible demonstration of Asian superiority over the white man. M.A. Baig, a translator employed by the Government of India, noted in his annual report, "The sympathy of the entire Native Press was on the side of Japan," with word of each new Japanese victory "hailed with unbounded jubilation." ${ }^{568}$ Baig cited five reasons for India's prejudice in favor of Japan, including the belief that Japan was fighting in a just cause in the defense of its independence;

\footnotetext{
${ }^{567}$ Ibid.

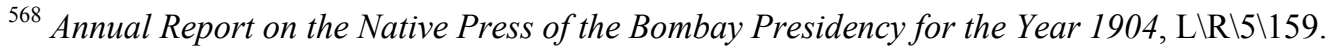


religious "affinities" between Indians and their Asian brethren; charitable donations from Japan during the famine of 1900; and the belief that Russia's setbacks would prevent any Russian incursion into India.

The last and perhaps most significant rationale Baig offered for India's sympathies was a native conviction that the all-encompassing nature of Japan's success at war and at home "had in some measure revolutionized the attitudes of the European mind towards the capabilities of Asiatic races to work out their own salvation." ${ }^{969}$ As if to underscore Baig's theory, Bal Gangadhar Tilak's Marathi-language paper, the Kesari, pronounced properly-equipped Asian forces "more than a match for any European army," and foresaw "nothing inherently improbable in the Asiatic nations becoming independent and taking rank with their European rivals. ${ }^{1570}$ Not content to cheer from the sidelines, Tilak's paper lobbied the Native Princes to outfit a much-needed hospital ship for the Japanese. Moreover, the paper launched a charity drive in the Deccan, collecting donations one rupee at a time, and ultimately sending four installments of 500 rupees to the Yokahama Specie Bank in aid of impoverished Japanese soldiers. ${ }^{571}$ Tilak looked to the example of Japan as a template for India's development as an independent nation. There was, in his writing, a strong core of Asian nationalism that looked for a profound significance in the outcome of the Russo-Japanese War. The victory was important not only for what it revealed about Japanese military strength, but also for what it announced to the world about the strength of the Asian character. Moreover, Tilak was undoubtedly

\footnotetext{
${ }^{569}$ Ibid.

${ }^{570}$ Cited in Ibid.

${ }^{571}$ Ibid.
} 
peering into the future - anticipating a time when India's political and commercial alliances lay with her Asian partners and not with the Raj.

Britain would have been wise to have taken note of the pan-Asian sentiment that the native press had earlier expressed during the Boxer Rebellion. Then, journalists had almost wistfully expressed admiration for the peasant farmers and their cause. The Chinese rebels, however, were victims, and despite their efforts to eliminate the Christian missionaries and oust the occupiers from their country, they could, in the end, function as little more than a symbol of Asian despair at Western oppression. The rise of the Japanese provided a dramatically different storyline, representing the first Asian nation to challenge and defeat a European empire. These were not peasant farmers on a mission whose failure was preordained; these were trained, disciplined warriors. As such, they represented the hope for the emergence of a new Asian empire that would elevate the status of all Asians, end the colonial status of millions, and usher in an era of independence from the Western yoke.

The Indian native press was thus decidedly vocal in in its expression of sympathy and support for the Japanese cause. "The Indians love the Japanese as their own kith and kin," gushed the Deshabhakta, demonstrating the surge of pan-Asian sentiment so prevalent on the subcontinent. ${ }^{572}$ Reminding their readers of Japanese assistance during the Indian famine, Tilak and his fellow editors exhorted their readers to reciprocate the kindness and contribute to the Japanese cause, not merely in terms of monetary donations and medical supplies, but also with the offer of Indian troops. ${ }^{573}$ Noting that all of this

${ }^{572}$ Deshabhakta, 21 February 1904.

${ }^{573}$ Kesari, 20 February 1904. 
support ran counter to Britain's demand that India remain neutral in the conflict, the sharp-tongued Kál commented, "All that we are required to do under their rule is to pay taxes to British officers and to be ready to starve at the approach of famine." ${ }^{\circ 74}$ Having criticized imperial policy for the manner in which it had conducted the wars in China and South Africa, the paper now used the Russo-Japanese conflict as a vehicle to lash out at Britain for her passive neglect of India.

Indian nationalist journalists saw in Japan's ascendancy a shift in the dynamics between Asia and Europe. Even before hostilities commenced, the Shri Sáyaji Vijay identified the consequences at stake, declaring, "The war will decide the momentous question whether Asia has vitality enough to maintain her own independence or whether she is destined to be in a position of perpetual servitude to Europe." ${ }^{575}$ The Kál, even more pronounced in its anti-British sentiment than the Kesari, crowed, "Every Asiatic is convinced that all European powers are bound to crumble before an energetic onslaught, while the Hitechchhu trumpeted its belief that Europeans would be guilty of the most profound folly if they continued to regard Asia "as only a happy hunting ground for the people of Europe to extend their sway." ${ }^{576}$ The Indian nationalist press was both confident and forthright in its belief that Japan's bold moves would dramatically alter the balance between the continents.

More than offering promise for a resurgent Asia, however, the Russo-Japanese War provided considerable opportunity for journalists to reflect upon what they viewed

\footnotetext{
${ }^{574}$ Kál, 15 January 1904.

${ }^{575}$ Shri Sáyaji Vijay, 16 January 1904.

${ }^{576}$ Kál, 18 March 1904; Hitechchhu, 29 May 1904.
} 
as pronounced differences between the status of Japan and the subcontinent. Pointedly observing that Europe continued to dominate Asia, with the notable exception of Japan, the Kál decried the fact that "Japan alone is completely independent, while India is completely under British domination." 577 "Alas!” exclaimed the Baroda Vatsal, before asking (referring to Indians), "When will they be free from this wretched condition of slavery and be fired with the spirit that animates the entire population of Japan today?"578 The Aronodaya lamented, "The position of the people of India has become like that of a child whose mother will not give it food and whose father will not allow it to beg." ${ }^{, 579}$ A degree of despair had crept into the columns of the native press, as India labored to recover from an onslaught of natural and man-made disasters. In an effort to explain why India gazed so "wistfully" upon the success of Japan, the Kál enumerated each adversity of the past ten years, listing among others plague, famine, the impotence of the Indian National Congress, the passage of "terrible and stringent laws," and the failure of the Government to grant political rights. ${ }^{580}$

The comparisons between the Japanese and the Indians echoed the tactics of the Irish advanced-nationalist press during the Second Boer War. In the same manner that the United Irishman and Workers' Republic had used the example of the independenceloving Boers as a spur to goad their Irish readers into fighting for self-government, so too Indian nationalist editors now identified the Japanese as a model for Indians to emulate.

\footnotetext{
${ }^{577}$ Kál, 18 March 1904.

${ }^{578}$ Baroda Vatsal, 22 May 1904.

${ }^{579}$ Aronodaya, 28 August 1904.

${ }^{580}$ Kál, 12 August 1904.
} 
The Gujarati asserted, "The people of India cannot but derive some elevating inspiration from the brilliant display of the magnificent qualities which the Japanese have exhibited in this epoch-making war." 581 Given the pessimism regarding India's future, Japan's successes certainly served as a beacon of hope, functioning as a possible template for how India could obtain her independence.

Yet, there were many voices in the native press warning that such slavish admiration of Japan would do nothing to advance the cause of India. The Gujarati, itself, advised, "Those who are content to plume themselves upon Japanese victories labour under very mistaken notions about the factors which go to build up the political greatness of a nation." 582 The paper cautioned, "If India remains satisfied with beholding the progress of other nations instead of endeavoring to ameliorate her own conditions, further degradation for her is inevitable. ${ }^{, 583}$ Moreover, not all journalists were convinced that India was even capable of following Japan's lead, identifying what they deemed stark differences between the Japanese and Indian characters. In an article strikingly reminiscent of D.P. Moran's essay on Irish character flaws, the Aryávart praised the Japanese as "energetic and diligent, unmoved by adversity and unflinching in danger," while dismissing the Hindu as "feeble and effete, sunk in sloth and indifferent to the best interests of his country." 584 In a comparison that surely would have surprised Moran, the Shri Fattehsinh Gazette spied a telling connection between the tactics of the Japanese and

\footnotetext{
${ }^{581}$ Gujarati, 4 September 1904.

${ }^{582}$ Gujarati, 18 June 1904.

${ }^{583}$ Ibid.

${ }^{584}$ Aryávart, 6 August 1904.
} 
the Irish, both of whom were "bent upon gaining independence." 585 The paper contrasted their actions with those of Indians, who had grown "inured to slavery and hypnotized by the crooked policy of the British." ${ }^{586}$ Weary of patiently coaxing their readers into asserting their rights, many in the Indian nationalist press now resorted to candid criticism of their countrymen, in an effort to break the pattern of Indian enfeeblement and complacency.

The Russo-Japanese War granted Indian journalists scope to examine India's relationship with Britain, and to compare their imperial experience with those of India's Asian neighbors. Whereas Japan had closed its borders to foreigners and actively maintained fierce control of its own government, India had been invaded, overrun, and subjugated. In February of 1904, a twelve-year-old letter from British philosopher and sociologist Herbert Spencer to Baron Kaneko, a Japanese jurist and philosopher, surfaced in the London Times — and became a timely talking point for Bal Gangadhar Tilak in both the Mahrátta and the Kesari. The letter had ostensibly cautioned the Japanese people to “keep the Europeans and the Americans as much as possible at arm's length," and suggested that Japan's intention to open its empire to foreigners and foreign capital was folly. Indeed, Spencer's letter had specifically warned his Japanese correspondent, "If you wish to see what is likely to happen, study the history of India."587 "Unfortunately," Tilak lamented, "there was no Herbert Spencer in the fifteenth and sixteenth centuries to give similar advice to the Indians when the country was exposed to the incursions of

\footnotetext{
${ }^{585}$ Shri Fattehsinh Gazette, 1 May 1904.

586 Ibid.

${ }^{587}$ Letter from Herbert Spencer to Kentaro Keneko, 26 August 1892. Internet; available at http://praxeology.net/HS-LKK.htm; accessed on 2 February 2013.
} 
European nations like swarms of locusts."588 Shivram Mahadev Paranjape, editor of the Kál, also seized upon Spencer's letter to condemn the actions of Christian nations who “send, as pioneers, missionaries of 'the religion of love,' and then pick quarrels with native races and take possession of their lands." ${ }^{, 589}$ Paranjape excelled at cataloguing for his readers the litany of grievances suffered at the hands of the European powers, as a result of what he characterized as hypocritical policies.

As with their coverage of the Boxer Rebellion, many leading Indian journalists viewed both religion and race as critical factors in the increasingly fractious relationship between Asia and Europe. The Hitechchhu painted a picture of "white demi-gods" utterly "panic-struck at the yellow peril," while the Kál extended its commentary to Africa and warned, "It is not only the Yellow Peril that Europe has to dread. A Black Peril seems also to be in sight." Exulting in the knowledge that the West "has been beaten with its own weapons," the Jam-e-Jamshed asserted that the Russo-Japanese War had not only demonstrated Japan's resources and daring, but also its training and discipline — placing the "white, black and yellow races on the same level."590 For an Indian people perennially reminded of their “inferior” status, Japan's rout of Russia

\footnotetext{
${ }^{588}$ Kesari, 23 February 1904.

${ }^{589} \mathrm{Kál}$, 20 May 1904. Herbert Spencer was not the only literary figure to whom the native press alluded in its coverage of imperial conflicts. Britain's incursion into Tibet found both the Kál and the Kesari looking for inspiration to the renowned novelist Count Leo Tolstoy. To provide support for its rationale in backing Japan, the Times of London had reprinted Tolstoy's letter to the Tsar, in which he offered a ringing denunciation of the Russo-Japanese War. The Kál chided the Times - and by implication the British Empire-for not seeing in the Russian behavior a reflection of its own actions in Tibet. (22 July 1904) The Kesari concurred, condemning the Tibet expedition, "though its real character is veiled under the sanctimonious name of a peace mission." (24 July 1904)

${ }^{590}$ Jam-e-Jamshed, 4 January 1905.
} 
provided tangible evidence that the days of Asian and African submission to Western tradition, custom, and religion were nearing an end.

Tilak's Marathi-language Kesari chose to harp on the religious bias that separated the West and East, assailing the hypocrisy of Christians who "preach philanthropy, benevolence, and the brotherhood of man," while simultaneously pursuing policies cloaked in "selfishness, cruelty and oppression." "591 "Though their religion teaches that all men are the children of one God," charged the Kesari, "they boldly maintain that the world was created by God for them, and that all other people are intended to be their slaves." 592 The paper provided its readers with historical examples of this pattern, noting that Christian nations "have hunted the Red Indians in America out of existence and also whitened the soil of Australia with the bones of the aborigines. ${ }^{\text {"993 }}$ The message was clear: the Christian British Empire would not be content until it had enslaved and converted the whole of the Indian subcontinent. Christian hegemony was obviously not a factor on which the Irish advanced-nationalist press was focusing. Indeed, they seemed curiously unaware of the prejudice they were displaying in their persistent references to the "Yellow Peril" and a "small race of Yellow People."

Japan's victory over Russia in the bloody Battle of Mukden afforded the Indian nationalist press even more reason for exultation, providing what journalists deemed demonstrative evidence of Japan's military discipline. The Kesari hailed it as an "epochmaking victory," while the Gujárati informed its readers that Japan had "covered itself in

\footnotetext{
${ }^{591}$ Kesari, 16 August 1904.

${ }^{592}$ Ibid.

${ }^{593}$ Ibid.
} 
imperishable glory." ${ }^{594}$ Notably, the latter paper attributed the victory to what it characterized as "peculiarly Asiatic" qualities of fearlessness, imperturbability, "thoughtfulness and resignation, abstinence and self-control, tenderness and humanity." 595 The message was clear: these were the same qualities present in the Indian people, who only needed to martial their inner resources to make the same dramatic impression on the West as their Japanese brethren. Native journalists used the war as a call to arms - a declaration that the time had come for India to seize control of its own destiny — and Japan's ultimate victory over Russia would only deepen those convictions. The Praja Bandhu asserted, "The idea that Christian nations are destined to rule the world has been rudely shaken to its foundations," while the Gujarati Punch declared that the war had taught the world that an Asiatic Power possessed both the intelligence and the military capabilities to best a European Power on the field of battle. ${ }^{596}$ The Indu Prakash issued the solemn pronouncement, "The restless West has rudely awakened the slumbering East." ${ }^{\text {597 }}$ Despite the fact that India's fairly harmonious association with Britain bore little resemblance to the combative relationship between Japan and Russia, Indian nationalist journalists continued to use the example of the war to encourage their countrymen to break the bonds of decades of subservience.

Watching and reading from his vantage point in Dublin, Arthur Griffith was encouraged by what he perceived as a possible shift in the balance of power in India. Sharing the Indian editors' contempt for the British, Griffith took delight in the idea that

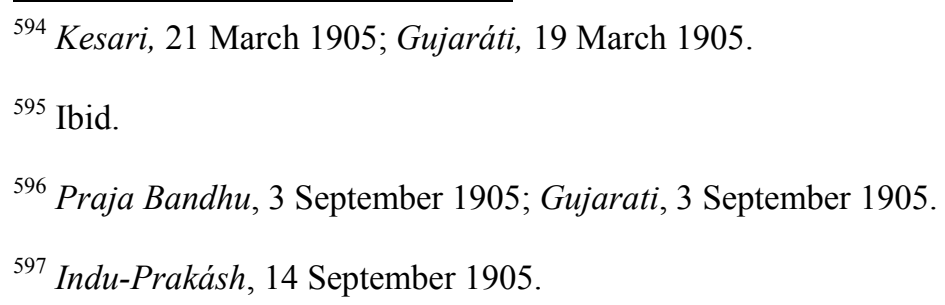


the Empire's aura of invincibility had been irreparably punctured by the defeat of the Russian Empire. The Irish editor was also quick to note the change in the tone of India's newspapers, crowing that the Hindu papers had supplanted their former "humbleness" with a new "manlier spirit." ${ }^{598}$ Griffith applauded the change in attitude wrought by the one-two punch of the Boer War and the Russo-Japanese War, crowing of Japan's ascendancy to the "paramount military, political, and commercial power of the Far East.. ${ }^{, 599}$ Not only did Griffith allege that Japan's surge to power had done irreparable harm to British trade and commerce, but also he anointed Japan as the Protector of India, "thus ending British-rule-by-prestige over the Hindus.",600 "India has developed a strong national spirit," Griffith exclaimed, "and embarked upon a fighting policy against England." ${ }^{601}$ It suited Griffith to depict India as ablaze with revolutionary zeal—an example to Ireland of a people committed to the glorious fight for independence. Although the Partition of Bengal undoubtedly galvanized India's nationalists, however, there was, as yet, no cohesion between the Moderates, who wished to work with the British Government, and the Extremists, who were beginning to espouse Home Rule.

Nor did all of India's native journalists embrace the war's end in a spirit of optimism. Just as Irish advanced-nationalists had deplored the Anglo-American alliance, so the chief source of unease for India's nationalist editors was the renewal of the 1902 alliance between Japan and Britain, which the Bhála declared "has dealt a death blow to

\footnotetext{
${ }^{598}$ United Irishman, 9 September 1905.

${ }^{599}$ Ibid.

${ }^{600}$ Ibid.

${ }^{601}$ Ibid.
} 
the military ambition of India." 602 There was the overwhelming sense that Britain had no faith in its loyal Indian subjects, given that Britain chose to align itself once again with Japan, a foreign power, "instead of keeping faith with them and training them for war.",603 With a threat of a Russian invasion no longer looming, the Bhála lamented what it perceived as the increasing effeminacy of the Indian people. "In course of time," warned the Bhála, "the country will be converted into a huge sheep-fold and the people, like sheep, will do nothing more than bleat when they are ill-treated."604 The Indu-Prakash worried that the alliance had robbed Japan's defeat of Russia of any of its benefits for the people of India, stating, "They expected that the rise of such a formidable power in Asia as Japan, added to Britain's old dread of Russia, would serve as a check on her despotism in India.",605 "Instead," argued the Indu-Prakash, "England has dexterously and at the price of her dignity and prestige as a European Power, liberated herself from all fear of Japan's might and influence, as well as from the dread of a Russian invasion of India." The renewal of the alliance may have improved the Empire's relations with Japan and lessened the fear of a Russian invasion of India, but it left the impression that Britain would never entrust the defense of India to native troops. The Empire's continued enfeeblement of the Indian people nettled nationalist journalists, who resolved to instill in their readers the same fire and intensity displayed by the Japanese.

\footnotetext{
${ }^{602}$ Bhála, 11 September 1905. The alliance was renewed again in 1911, and was not officially terminated until 1923.

${ }^{603}$ Swadesi, 4 November 1905.

${ }^{604}$ Bhála, 11 September 1905.

${ }^{605}$ Indu-Prakash, 16 September 1905.

${ }^{606}$ Ibid.
} 
The Russo-Japanese War marked the last of the grand international conflagrations jeopardizing the hard-won equilibrium of the British Empire. ${ }^{607}$ Despite the absence of a British imperial war for more than a decade after the Boer War had wound to a close, journalists in Ireland and India continued to turn their gaze overseas. Rather than focusing on military tactics and casualty reports, Irish and Indian nationalist editors found a rich source of inspiration in their mutual struggles for self-reliance. Journalists instantly recognized the common elements in the Indian program of Swadeshi and the Irish Sinn Féin policy, and undoubtedly derived a certain satisfaction in realizing that their contemporaneous movements were threatening to become dangerous distractions for the Empire. Significantly, nationalist editors went to great lengths to cover each other's internal battles with the Empire, in the process following their pattern of transforming foreign events into fodder for their own domestic agenda. Irish journalists covered the Partition of Bengal and the subsequent Swadeshi movement as if the events were clashes in yet another of Britain's imperial wars. For their part, Indian journalists tracked every aborted phase of Ireland's struggle to achieve Home Rule, informing their readership of Irish tactics and British treachery. Bal Gangadhar Tilak and Arthur Griffith assumed the lead in this crusade, characterizing the fledgling movements of Swadeshi and Sinn Féin as impassioned struggles pitting freedom-loving peoples against an overreaching Empire determined to smother Irish and Indian independence.

\footnotetext{
${ }^{607}$ Although Britain enjoyed several years without a major war, the intense rivalry between Britain and Russia - primarily over the domination of Central Asia - would continue to simmer for several more years. The two mighty powers had been engaged in this "Great Game" since the Russo-Persian Treaty of 1813, attempting to out-strategize and out-maneuver each other from the hills of Afghanistan to China, Mongolia, and Tibet. In 1907, the Great Game largely came to an end, as Germany's rise to world prominence demanded the necessity of an Anglo-Russian rapprochement.
} 


\section{The Sinn Fein Policy}

While the Indian nationalist press attempted to motivate the masses by concentrating its attention on the conflict in Asia, Arthur Griffith instead used these years to reinvigorate the cause of Irish nationalism by looking to the past. Significantly, the editor once again looked abroad, to continental Europe's recent history. In 1867, Hungarian Franz Deak had launched a campaign of non-cooperation-refusing to send representatives to the Imperial Parliament — which ultimately compelled Austria to form a dual monarchy with Hungary. Griffith held up the Hungarian model as evidence that Ireland could successfully combat the British without resorting to arms. Like his Hungarian counterparts, Griffith advocated a political policy of non-cooperation, demanding that Ireland withdraw its representatives from the British Parliament. In an editorial entitled "Is Emigration Inevitable?" the United Irishman denounced the "bloody, rapacious, and soul-shivering Imperialism of England" and proclaimed "Let us renounce the disastrous policy of making the Parliament House of England the arena of the Irish struggle - let us make the dissolution of the British Empire our immediate object and “Delenda est Carthago!" our rallying cry ...."608 Griffith's appropriation of the Elder Cato's classic call to arms indicated the editor's desire for Ireland to adopt its own scorched earth policy when it came to relations with England.

As the Indian nationalist press focused on the Russo-Japanese War throughout 1904, therefore, Griffith serialized "The Resurrection of Hungary” in the United Irishman, persistently drawing parallels between the two countries. Griffith was adamant

${ }^{608}$ United Irishman, 1 July 1899. 
that "what the Hungarians did for Hungary, Irishmen can do for Ireland." ${ }^{\text {,60 }}$ At year's end, desirous of reaching an even wider audience, the editor compiled the articles in a single volume. Griffith was rewarded for his effort, selling 20,000 copies of The Resurrection of Hungary within the first three months of its publication. Convinced of the rightness of their thinking, and adamant that any solution must come from Ireland and not Britain, Griffith and his fellow proponents soon adopted the name Sinn Féin—-for their movement. ${ }^{610}$ Convening the annual meeting of the National Council in December 1905, delegates proposed the new Sinn Féin policy of National Self-Determination, in which members pledged themselves to aid and support any nationalist group "not looking outside Ireland for the accomplishment of their aims." ${ }^{\text {"11 }}$ Not surprisingly, the Sinn Féin movement adopted the United Irishman as its official organ. Griffith's paper subsequently featured an invitation to join the new organization, urging its readers to show their support of the National Council by filling in the handy form on page eight. Not all advanced nationalists were enamored of Griffith's plans for Ireland. D.P. Moran, editor of the Leader, ridiculed adherents of the new political ideology, dubbing them "Griffith’s Green Hungarian Band."612 Socialist James Connolly offered more substantive criticism, listing a catalogue of adverse conditions in Hungary that included

\footnotetext{
${ }^{609}$ Arthur Griffith, The Resurrection of Hungary (Dublin: University College Dublin Press, 2003; first published 1904), 95.

${ }^{610}$ While there may be reasons this slogan was adopted by Griffith and his nationalist companions, it is difficult to discount the theory that they were influenced by Douglas Hyde's 1897 Irish poem "Waiting for Help," whose last verse reads, "Is mithid fios do bheith / Ag gach aon amadán / Nac bhfuil gair-faire / Is fiú aon aire / Acht ceann, Sinn Féin Amháin!' P.S. O’Hegarty's translation reads: "It is time for every fool to recognise that there is only one watchword which is worth anything-Ourselves Alone." Cited in P.S. O’Hegarty, Sinn Féin: An Illumination (Dublin: Maunsel \& Co., Ltd., 1919), 20.

611 “Invitation to join Sinn Féin,” 9 December 1905, in Ibid, 143.

${ }^{612}$ Cited in Kee, 157.
} 
historically high emigration to America, the "misery of the town and country workers," and the denial of the vote to the "producing classes," as reasons Ireland should not adopt the Hungarian model. ${ }^{613}$ "We are inclined to wonder," mused Connolly, "if our Sinn Féin orators know these things, or are they only presuming upon the ignorance of the Irish Workers." ${ }^{.614}$ These criticisms notwithstanding, Connolly had strong praise for the underlying concept of Sinn Féin, asserting, "It teaches the Irish people to rely upon themselves, and upon themselves alone, and teaches them also that dependence upon forces outside themselves is emasculating in its tendency, and has been, and will ever be disastrous in its results. ${ }^{, 615}$ Moreover, Griffith's ideology met with the approval of members of the Irish Parliamentary Party—long a target of the editor's scorn—with T.M. Kettle praising the program as "the largest idea contributed to Irish politics for a generation." ${ }^{616}$ The Sinn Féin emphasis on self-reliance did, indeed, invigorate the cause of Irish nationalism and transform the political landscape — not only in Ireland, but also in America, where John Devoy's Gaelic-American was instrumental in disseminating word of the program.

The economic policy expounded by Griffith and Sinn Féin, however, provoked a measure of controversy, rejecting as it did Britain's policy of free trade in favor of Irish protectionism. Once again drawing inspiration from continental Europe, Griffith had seized on the theories of the German economist Friedrich List, whose book The National

\footnotetext{
${ }^{613}$ James Connolly, "Sinn Fein and Socialism," The Harp, April 1908; Internet; available at http://www.marxists.org/archive/connolly/1908/04/sinnfein.htm; accessed on 10 February 2013.

${ }^{614}$ Ibid.

${ }^{615}$ Ibid.

${ }^{616}$ Cited in Colum, 77.
} 
System of Political Economy had been published in 1885. Writing in The Resurrection of Hungary, Griffith hailed List as "the man who saved Germany from falling prey to English economics," and lauded the German for linking economic policy to the principle of nationality. ${ }^{617}$ Already pledged to a glorious Gaelic revival, Griffith understandably approved of List's definition of a nation as possessing "a common language and literature. ${ }^{, 18}$ In Griffith's estimation, England had ignored Ireland's manufacturing capabilities in favor of classifying the island's resources as purely agricultural. ${ }^{619}$ The inequity between Ireland's "flocks and herds" and the manufactured goods of Britain placed Ireland at a distinct commercial disadvantage, always dependent on her wealthier trading partners. ${ }^{620}$ Warming to his subject, Griffith pleaded for the Irish "to clear their minds of the pernicious idea that they are not entitled or called upon to give preferential aid to the manufacturing industries of their own country." ${ }^{2621}$ As enamored of List's theory as he was of the Hungarian Policy, Griffith proved equally blind to its shortcomings as an economic solution for Ireland, given the limited resources to which Ireland had access on the island. ${ }^{622}$

${ }^{617}$ The Resurrection of Hungary, 142.

${ }^{618}$ Cited in Ibid, 143.

${ }^{619}$ The exception to this was, of course, Belfast, which was a hive of industry, led by the successful shipbuilding company of Harland and Wolff, established in 1861, builders of the RMS Titanic.

${ }^{620}$ The Resurrection of Hungary, 142.

${ }^{621}$ Ibid, 146.

${ }^{622}$ Taking a closer look at List's policies, Virginia Glandon commented, “Griffith apparently ignored List's argument that a small state could never perfect production within its borders because of inadequate resources." Glandon, 32. 
Yet, Griffith understood that there was resistance to his theories from those who questioned the practicality of Sinn Féin's policy of self-reliance. Responding to his critics, as well as the unconverted, Griffith launched a follow-up to his serialization of The Resurrection of Hungary, publishing a series of articles entitled "A Working of the Policy" that would run in the United Irishman throughout 1905. The editorials offered concrete proposals for transforming Ireland from a client state to a self-reliant country ready to assume its place among the nations of the world. Championing Irish investment in Irish industry and Irish consular representation on the Continent to promote trade, Griffith also promoted the founding of an Irish national university, an Irish Bar, and an Irish bank. Among his more provocative ideas was the establishment of an entente cordiale between Ireland, the Transvaal, India, and Malta. Acknowledging the complicity of Irish troops in suppressing dissent among the Boers, Hindus, and Maltese, Griffith asserted that such an entente would prevent the countries "from being used to strangle each other for England's benefit." ${ }^{, 623}$

\section{The Swadeshi Movement}

While Arthur Griffith was hammering out the details of the Sinn Féin policy, Indian nationalist journalists were shifting the attention of their readers from the RussoJapanese War to a firestorm erupting within India's own borders. On the surface, the 1905 Partition of Bengal — a populous province spanning 189,000 square miles and home to Bengalee editor Surendranath Banerjea — must have seemed like a bold administrative gesture, designed to ameliorate what Lord Curzon described as the "complete lack of

${ }^{623}$ United Irishman, 12 May 1905. 
touch between the centre and the extremities."624 "The necessity for relief is indisputable," argued the Viceroy, adding, "The administration of Bengal is bad, and it is bad because the work is far too great for any individual man." ${ }^{, 625}$ Certainly, the Viceroy was not blind to the possibility of protest from the residents of Bengal as well as from Indian nationalists. In particular, he identified the "wire-pullers" and "frothy orators" of the Indian National Congress as the font of agitation, noting, "They dominate public opinion in Calcutta; they affect the High Court; they frighten the Local Government; and they are sometimes not without serious influence upon the Government of India. ${ }^{626}$ Bengal had long been a seat of unrest and was threatening to become a hotbed of revolutionary crime. When word of the Government's plans leaked to the public, the rumblings of discontent soon grew to a roar.

Still, the Viceroy was convinced that however heated the protest against the Partition might be, it would be local in nature, as well as short-lived. Remarkably, the Viceroy seemed unconcerned about the impact the Russo-Japanese War was having on Indian aspirations. Notwithstanding his cognizance of the fervor of Indian nationalists, in this instance Curzon apparently elected to rely on the wisdom of a "Native gentleman," who had informed the Viceroy, "My countrymen always howl until a thing is settled; then they accept it." ${ }^{\text {,27 }}$ In pursuing the course of Partition, Curzon woefully

${ }^{624}$ Ibid.

${ }^{625}$ Lord Curzon to John Brodrick, 2 February 1905, 1904-5. The Lord Curzon. Correspondence with Secretary of State, Mr. Balfour, Lord Lansdowne, Sir A. Godley, \&c. Commencing from December 1904, MSS EUR F 111/164.

${ }^{626}$ Ibid.

${ }^{627}$ Ibid. 
underestimated the impact on the proud Indian psyche. Contributing to the native ire was the manner in which the government elected to divide Bengal, bisecting the province into an East Bengal with a Muslim majority and a West Bengal where a non-Bengali-speaking majority could overrule the wishes of a Bengali-speaking minority. Critics suspected the viceroy felt intimidated by the growing nationalist spirit among Hindus, and was attempting to create an equally vocal Muslim contingent to counterbalance the threat. The outcry in response to the Partition was immediate, insistent, and to Curzon's dismay, enduring, led by members of the Indian National Congress such as Gopal Krishna Gokhale, who accused the British government of callously demonstrating "utter contempt for public opinion. ${ }^{, 628}$ The Partition of Bengal not only produced a predictable Bengali backlash against the Empire, but, more importantly for the Raj, also gave birth to the nationwide Swadeshi ("self-sufficiency") movement. What had begun as a Bengal-based economic protest urging the boycott of all things British would evolve into an inwardlooking and forward-thinking national program of Indian self-reliance.

Predictably, the Indian nationalist press, led by Bal Gangadhar Tilak, mounted a ferocious protest against the Partition. Whereas the Mahrátta employed a more measured tone in criticizing the Government's strategy, the Kesari, published in the vernacular, issued a blistering condemnation of the imperial move, proclaiming: "Never before has public opinion been so ruthlessly trampled under foot by a hard-hearted and autocratic Viceroy as by Lord Curzon in the matter of the partition scheme. ${ }^{, 29}$ For Tilak, a man who had spent much of his life protesting the polices of the British in India, and

\footnotetext{
${ }^{628}$ Cited in Stanley Wolpert, A New History of India (New York: Oxford University Press, 2000), 273.

${ }^{629}$ Kesari, 20 August 1905.
} 
bemoaning the absence of collective, concerted agitation on the part of India, the Partition of Bengal offered unrivaled possibilities for achieving Indian solidarity. The Kesari stated unequivocally, "A boycott of foreign goods is the only remedy lying in the hands of an utterly helpless people like the Indians to enable them to compel Government to accede to their demands. ${ }^{930}$ Ever the opportunist, Tilak saw the efficacy of focusing his readers' anger, enlisting their energies in the cause of Swadeshi.

Throughout 1905 and 1906, the Kesari carped at those who did not comprehend the magnitude of the moment, or the need for action, warning, "Mere words are bound to be useless in removing the scales of selfishness and pride of authority that darken the vision of officials. ${ }^{631}$ In Tilak's estimation, boycott and Swadeshi were "two phases of the same movement indissolubly connected together. Exclude the boycott from the Swadeshi movement and the latter becomes lifeless. People will not persevere in the Swadeshi movement, unless they burn with indignation at Manchester forcing upon us thirty crores worth of piece-goods and robbing the country of so much wealth." ${ }^{, 632}$ Tilak was not the only Indian nationalist to make this connection. In a speech at College Square in Calcutta in 1907, Bengalee editor Surendranath Banerjea elaborated on the relationship between the two movements, explaining to his audience, "Boycott is the negative and Swadeshi is the positive aspect of the same question, and I, for my part, am not prepared to separate them.." ${ }^{, 633}$ Convinced that boycott and Swadeshi could not in and

\footnotetext{
${ }^{630}$ Kesari, 5 September 1905, from Weekly Report, $\mathrm{L} \backslash \mathrm{R} \backslash 5 \backslash 160$.

${ }^{631}$ Kesari, 22 August 1905, from Ibid.

${ }^{632}$ Kesari, 26 September 1906, from Weekly Report, $\mathrm{L} \backslash \mathrm{R} \backslash 5 \backslash 161$. The value of one crore is ten million; therefore, the "thirty crores worth of piece-goods" amounts to 300 million.
} 
of themselves constitute an enduring program of Indian nationalism, Tilak added two more basic tenets to the movement: the cause of national education and the pursuit of swaraj — home rule — with the editor proclaiming, "Swaraj is my birthright and I shall have it!"

Not surprisingly, Anglo-Indian papers such as the Times of India registered their dismay both at the movement itself and, particularly, at its support in the native press. In rejecting their complaints out of hand, Tilak asserted that the reason Swadeshi lacked support among the Anglo-Indian press was "because there are comparatively few matters relating to the Indian administration, which touch the Anglo-Indian Press to the quick as they do the Native Press." ${ }^{934}$ Still, just as Arthur Griffith's Sinn Féin movement had its notable detractors in the press, not everyone in the native press of India was as enamored of the movement as Tilak. The Jam-e-Jamshed — which would eventually stake out a position opposing the policies of the Indian National Congress - dismissed the campaign, sniffing, "The silly vapourings against the British Government, the seditious circulars, the letters of intimidation to peaceful citizens, and even outrages in certain cases have given to the present agitation an aspect which is far from merely comic." ${ }^{635}$ The Advocate of India predicted that the Swadeshi movement was doomed to failure, and expressed surprise that someone of Tilak's stature would allow himself to become embroiled in "such a piece of puerile folly." ${ }^{636}$ The Mahrátta refuted that characterization, urging the

\footnotetext{
${ }^{633}$ Reported in the Statesman, 4 August 1907. Cited in Note on the Origin and Character of the Swadeshi

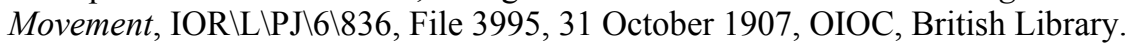

${ }^{634}$ Mahrátta , 27 August 1905, from Ibid.

${ }^{635}$ Jam-e-Jamshed, 30 September 1905, from Weekly Report, L $\backslash \mathrm{R} \backslash 5 \backslash 160$.

${ }^{636}$ Advocate of India, cited by Mahrátta, 27 August 1905, from Ibid.
} 
Bengali population "to strain every nerve to persist in the movement," confident that Swadeshi would prevail. ${ }^{637}$ The Kesari-as always the more outspoken of Tilak's two papers - denounced the complacency and lack of vision of India's middle and upper classes, labeling their leaders "poltroons"- cowardly both in their demeanor and their actions. ${ }^{638}$ The Bhala exhorted the Bengali people to "wreak vengeance upon Government a hundredfold," and "ostracize all black sheep amongst them, who are mean enough not to stand by them in the present crisis." ${ }^{939}$ While the Swadeshi movement had its detractors, the vast majority of India's native newspapers joined with the Mahrátta and the Kesari to throw their combined weight behind the Swadeshi movement.

\section{Hands Across the Sea}

Even more unsettling for the British Empire, however, was the fact that news of the Partition and the subsequent protests had reached an audience beyond the borders of the subcontinent. If events took on significance beyond their expected import, it was largely because the nationalist press in India and Ireland never stopped searching for ammunition with which to press their case. It was not unexpected that the Partition of Bengal would ignite a firestorm of controversy within Bengal and India. What proved more telling — and more problematic for the British Empire—was the focus on the issue by the Irish nationalist press. For Arthur Griffith and his Irish colleagues, events in India could not have proved more felicitous. To Irish nationalist proponents, the Partition of

\footnotetext{
${ }^{637}$ Mahrátta, 27 August 1905, from Ibid.

${ }^{638}$ Kesari, 5 September 1905, from Ibid.

${ }^{639}$ Bhala, 11 September 1905, from Weekly Report, L $\backslash \mathrm{R} \backslash 5 \backslash 160$, OIOC, British Library.
} 
Bengal and resultant outcry in India constituted yet another instance of imperial meddling, misreading, and mishandling of a global event. The fact that Britain and India were not, in fact, engaged in a war did not stop the Irish advanced-nationalist press from characterizing the parties involved as foes. In the same manner they had appropriated the Boer struggle for independence to exhort readers to go to battle on behalf of Ireland, journalists now seized upon Partition and the ensuing protests as a model for the Irish to emulate. "Our Mutual Enemy" ran the headline of the Connaught Telegraph, and, in an attempt to shame its readers into action, followed up with a sub-heading which read "Brave, India! —What is Ireland Doing?" ${ }^{400}$ In its coverage of a well-attended speech by Camillo F. Saldanha on the state of "Young India," the Freeman's Journal reported the audience responded with applause when the speaker alluded to "the bond of common suffering and the bond of common hatred against the common oppressor of India and Ireland. ${ }^{, 641}$

While many in the advanced-nationalist press were urging Ireland to follow the lead of India, there was also an attempt from some quarters to take credit for India's new political movement, suggesting that Indian nationalists had adapted Arthur Griffith's ideas for their own purposes. The Southern Star excitedly noted that Griffith's pamphlet, "The Resurrection of Hungary" had been translated into Cingalese and other Indian dialects and had circulated throughout India, giving birth to the Swadeshi movement. ${ }^{642}$ The Irish Independent informed its readers that Bengal had engaged in "a

\footnotetext{
${ }^{640}$ Connaught Telegraph, 25 December 1905.

641 "Young India and its Aspirations," Freeman's Journal, 12 November 1906.

${ }^{642}$ Southern Star, 1 December 1906.
} 
sort of Sinn Féin policy with remarkable effects," and hoped that "the two movements, Indian and Irish, might result to mutual advantage.." ${ }^{, 43}$ Noting gleefully that "England may soon have more than one Ireland to deal with," the paper provided a helpful pointby-point comparison between the grievances of the Indian and the Irish. In addition to “crippled home industries," the Irish Independent reeled off the suppression of public meetings, the neglect of native languages, and, in particular, constraints on freedom of the press as hallmarks of British rule. The Freeman's Journal informed its readers that Indian newspapers "are persistently persecuted" and that British authorities had imprisoned the editor of the Punjabee for a period of two months. ${ }^{644}$

News of the Indian movement became so prevalent in the Irish nationalist press that there was no longer any need to describe in detail the movement or its aims. The anti-imperial goals of the Swadeshi boycott had become common knowledge. Editors found they could insert the word not only as a means to incite their readership to action, but also to provide the occasional moment of levity. When reports circulated that British authorities had shipped a mere one dozen cats to India in an attempt to eliminate the entire rat population of India and thus stem the spread of the plague, the Freeman's Journal expressed its skepticism—before waggishly suggesting the idea was Swiftian in its conception and had perhaps been invented "by some Bengalese who believes in the Swadeshi movement. ${ }^{\prime 645}$ The invocation of the name of the great Irish satirist indicated that the paper considered the British idea for controlling the devastating Indian plague

\footnotetext{
643 “Sinn Fein in Bengal," Irish Independent, 2 February 1906; 7 March 1906.

644 “The Indian Movement,” Freeman's Journal, 1 September 1907.

${ }^{645}$ Freeman's Journal, 15 August 1907.
} 
equally as preposterous as Swift's darkly comic proposal for coping with the Irish poor. ${ }^{646}$ Crediting a Bengali native with proposing the scheme, moreover, was an acknowledgement of how much Irish nationalists enjoyed watching Britain squirm under the pressure of the Swadeshi movement.

Arthur Griffith clearly recognized the Indian program as the equivalent of his Sinn Féin policy, which by 1906 had its own eponymous political organ as Griffith replaced the United Irishman with the Sinn Féin weekly, Ireland's new 'National Industrial Journal. ${ }^{647}$ Its premier number, appearing on 5 May 1906, threw down the gauntlet, charging, "It is because England has disarmed this country, because she has impoverished it, because she is strong that we write 'humbug' to the policy of trusting in England's sense of justice." 648 Emblazoned on the front page of the four-page paper were inspirational banners, featuring memorable sayings from political and literary luminaries such as Frederick the Great and satirist Jonathan Swift. A particularly pointed citation from Henry Grattan, the leader of the eighteenth-century Independent Irish Parliament, warned, "When the liberty and security of one country depends on the honour of another, the latter may have much honour, but the former can have no liberty."649.

Never one to let an opportunity slip away, Griffith immediately set about drawing the attention of his readers to the profound parallels between his political invention and the new Indian movement, publicly applauding Swadeshi and the boycott and crowing

\footnotetext{
${ }^{646}$ In his 1729 "A Modest Proposal," Jonathan Swift suggested that the poor of Ireland could ameliorate their devastating economic condition if only they would sell their young as food to the wealthy.

${ }^{647}$ The Sinn Féin daily would supersede the Sinn Féin weekly in 1909.

${ }^{648}$ Cited in Glandon, 41.

${ }^{649}$ Sinn Féin, 2 June 1906.
} 
"Hindus have learned that one ounce of the Sinn Féin policy is more effective than a ton of appeal in getting home to the British conscience. ${ }^{, 650}$ Denouncing editorials in the British papers that claimed Swadeshi was proving a failure, the editor exhorted his readers to emulate the Hindu oath never to buy British goods. ${ }^{651}$ In a comment that managed simultaneously to tip its hat to the Swadeshi movement and take a swipe at the Irish Parliamentary Party, the United Irishman suggested the time had arrived for Ireland and India to unite. "A common enemy, a common purpose, and similarity of circumstances," asserted the journal, "should have long ago led to common action on the part of the two peoples, had Ireland possessed leaders whose horizon was not bounded by the British House of Commons." ${ }^{652}$

Observers outside of Ireland and India were also taking stock of the parallels between Swadeshi and Sinn Féin. After explaining to its readers that the Hindi and Irish words were synonymous with "nous-même" ("ourselves"), the Parisian newspaper $L a$ Liberté pronounced it "remarkable that the same idea should be being acted on at the same time in Ireland and in India." ${ }^{" 653}$ In London, the Nation proclaimed that "The spirit of Swadeshi and Sinn Féin is everywhere making its way." ${ }^{\circ 54}$ In England, a student at Cambridge also noted the striking similarities between the Irish and Indian programs of self-reliance. Though in 1907 Motilal Nehru had advised his son to steer clear of Irish disturbances in Belfast, Jawaharlal Nehru's response was to declare his admiration for

${ }^{650}$ United Irishman, 9 September 1905.

${ }^{651}$ United Irishman, 11 November 1905.

${ }^{652}$ Ibid. United Irishman, 18 November 1905.

${ }^{653}$ United Irishman, 14 October 1905.

${ }^{654}$ The Nation, cited in The Irish Independent, 22 August 1910. 
Sinn Féin: "It is a most interesting movement and resembles very closely the so-called Extremist movement in India. Their policy is not to beg for favours but to wrest them. They do not want to fight England by arms, but 'to ignore her, boycott Her, and quietly assume the administration of Irish affairs." ${ }^{655}$ Nehru's comparison of Sinn Féin to the Extremists in India was an apt one, given that it was Tilak, the leader of the Extremist movement, who was responsible for the distribution of Sinn Féin pamphlets in India.

To the same degree Tilak harbored a conviction that India's prosperity depended on her Asian alliances, Griffith was desirous that Ireland take her place among the nations of Europe. To that end, Griffith often reprinted material from European newspapers, and boasted in turn of the coverage Ireland received in continental journals. He was particularly pleased when news of the Sinn Féin movement circulated on the continent. In the issue of 18 November 1905, he crowed, "Fifteen French, four Belgian, four German, two Spanish, two Dutch, one Austrian and one Italian newspaper publish this week for the first time in their existence, news of the national existence of Ireland." ${ }^{656}$ Having observed at a distance Ireland's land wars, Parliamentary obstructionism, and boycotts, India was clearly mesmerized by this latest stratagem of Ireland's nationalists.

Just as Griffith and his fellow nationalist editors saw the wisdom of continually placing the example of India before their readers, so did India's nationalist journalists document the newest tactics adopted by the Irish in their struggle for independence. The Vehari exclaimed, "A terrible Swadeshi movement is set on foot in Ireland ... the Irish

\footnotetext{
${ }^{655}$ Jawaharlal Nehru, Nehru: The First Sixty Years, Two volumes, edited by Dorothy Norman (New York: The John Day Company, 1965), 12.

${ }^{656}$ United Irishman, 18 November 1905.
} 
have given up all hope of being benefited by laws passed by the British Parliament."

The paper issued a call to action, demanding not only a boycott of all universities

established by the British Government, but also urging its readers to follow Ireland's lead

by boycotting enlistment in the British army and refusing to invest Indian capital in

Britain's financial institutions. ${ }^{658}$ The Gujaráti also urged its readers to emulate the Irish, asserting, "It is as a result of the sacrifices made by Irish leaders that Home Rule for Ireland has been brought within the range of practical politics." 659 The paper added, "If Indians want Home Rule at the hands of Englishmen, they should be prepared to undergo similar sacrifices." $" 660$ The Patriot invoked the name of Irish patriot Daniel O'Connell, whose "monster meetings" in 1843 demonstrated his awareness of the vital role played by the masses in political agitation. ${ }^{661}$ Michael Davitt's letter to the editor of the Indian Review found its way into the pages of the Mahrátta, whose editor clearly supported Davitt's contention that "It is not humanly possible for a people to be sincerely loyal to an authority which grinds them down with oppressive taxation while denying them the most elementary rights of constitutional rule." ${ }^{\text {,62 }}$ Upon hearing of Davitt's death in 1906,

${ }^{657}$ Vehári, 19 March 1906, from Weekly Report, $\mathrm{L} \backslash \mathrm{R} \backslash 5 \backslash 161$.

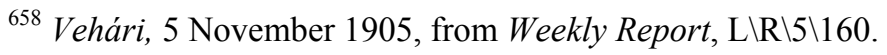

${ }^{659}$ Gujaráti, 9 June 1906.

660 Ibid.

${ }^{661}$ Daniel O'Connell (1775-1847), renowned as The Liberator, revived the moribund cause of Catholic Emancipation in 1829, and crusaded unsuccessfully in the 1840 s for the repeal of the 1801 Act of Union. Though not in favor of Irish separatism, he nevertheless promoted the idea of a united Irish front that could bring about political change. Campaigning throughout the Irish countryside, O'Connell addressed a succession of "monster meetings," whose attendance numbered in the hundreds of thousands. Indeed, with the example of Ireland always before them, India's nationalist leaders - from B.C. Pal to Mohandas K. Gandhi-would stage their own monster meetings, taking their movement to the masses.

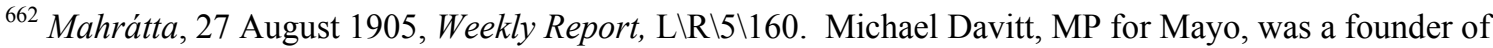
the influential Land League and one of the Irish Parliamentary Party's most activist voices. Frustrated, 
the Gujaráti Punch offered a mournful eulogy, intoning, "India's heart, even in the midst of her own wrongs and sufferings, ever goes out to Erin—-her sister in woe." ${ }^{963}$ The expression of sympathy may have spoken as much to the unhappy reality of India and Ireland's continued domination by Britain as it did to the passing of Davitt.

If there was one native newspaper the Government of India perennially labeled as dangerously seditious, it was the Bombay-based Kál. The paper urged its readership to heed Griffith's message and wrest primary, secondary, and collegiate education from the grasp of the British Empire. ${ }^{664}$ As Griffith and Tilak had documented in their papers, a British education omitted any mention of Irish or Indian culture and heritage, the English language took precedence over the Irish language or any of the several hundred Indian dialects, and British industry prospered at the expense of Irish and Indian industry. That being the case, Kál suggested that an occupying force did not need to employ brutal methods to produce a deleterious effect on the native population. Indeed, Kál claimed that Britain's "civilized mode of oppression and persecution is really far more dangerous and disagreeable than open torture or ill-treatment." ${ }^{\prime 655}$ Calling the effects of British rule in Ireland and India "strikingly similar and equally deplorable," the Kál exhorted its

\footnotetext{
Davitt left the House of Commons and turned his back on Parliament in 1896, uttering the fateful prediction that "no just cause can succeed there unless backed by physical force." Cited in Michael Davitt: Mayo's Most Famous Son, Connaught Telegraph; available at http://www.mayo-ireland.ie/Mayo/News/ ConnTel/CTHistry/MlDavitt.htm; Internet; accessed 14 November 2003.

${ }^{663}$ Gujaráti Punch, 10 June 1906.

${ }^{664}$ Kál, 15 June 1906, Vehari, 21 May 1906; from Ibid.

${ }^{665}$ Ibid.
} 
readers to follow the Irish example by becoming self-reliant, rather than depending upon British Parliament to grant Home Rule. ${ }^{666}$

The Kál also relayed Arthur Griffith's belief that the main problem confronting the Irish is "They do not at present realize ... that they form a nation." equated the Irish predicament with India's own dilemma, asserting that British rule "undermines the sentiment of nationality ... and reduces them [the natives] to a position worse than that of actual slaves. $" 668$ Bal Gangadhar Tilak similarly allotted generous space to Arthur Griffith's concept of nationality. Characterizing the misery of an Indian subject of the British Empire as identical to that of an Irish subject, the Kesari enumerated a quartet of elements identified by Griffith as the foundation on which to build a national movement. The critical ingredients were "(1) The realisation of those miseries; (2) the desire to be free from them; (3) patriots ready to work for freeing their countrymen from their miseries and (4) an educated middle class willing to give assistance to the patriots." 669 Indeed, Tilak worked to refine Griffith's first element in the evolution of national identity, by suggesting that misery was not, in itself, enough of a spur to action; rather, there must be the recognition of a common danger. In Tilak's estimation, that pervasive threat came in the form of imperial oppression. The editor of the Kesari asserted, "If no nation had been under foreign domination or at any rate exposed to the danger of such domination, the idea of nationality would never have

\footnotetext{
${ }^{666}$ Kál, 13 July 1906, from Weekly Report, from Ibid.

${ }^{667}$ Kál, 15 June 1906, from Weekly Report, L\R\5\161.

${ }^{668}$ Kál, 13 July 1906, from Ibid.

${ }^{669}$ Kesari, 13 February 1906, from Ibid.
} 
developed in the history of the human race." ${ }^{, 670}$ Underscoring the need for a unified front in the face of the British monolith, Tilak asserted, "The masses must have the power of cohesion, otherwise they will be like the particles of sand on the seashore." ${ }^{971}$ The editor left to his reader's imagination the unfortunate fate of those individual grains of sand when the next wave of imperial dictates washed over them.

This era was marked by a demonstrative spirit of solidarity between editors in Ireland, India (and even Irish-America), with a fluid exchange of ideas, as articles, commentary, and letters to the editor were printed in one paper, and rapidly reprinted in another. The Government of India had long prided itself on introducing western conventions of civilization and the rule of law to India, just as Dublin Castle was convinced that it exercised considerable restraint in dealing with the native Irish population. Yet, what the British regarded as paternal patience and tolerance was inevitably perceived by the native populace as condescension and patronization-a litany of polices designed to make India less Indian, Ireland less Irish. Recognition of their common plight forged a connection between Irish and Indian nationalist journalists. The Mahrátta frequently excerpted editorials from John Devoy's New York-based Gaelic-American, which fresh from its piercing, if biased, analysis of the Russo-Japanese War was calling for a triple alliance between Ireland, South Africa, and India. By joining the battle on three fronts, the paper asserted, "the war against the tyranny of the British can be brought to a successful and happy conclusion." ${ }^{672}$

\footnotetext{
${ }^{670}$ Kesari, 13 February 1906, from Weekly Report, L\R\5\161.

${ }^{671}$ Ibid.

${ }^{672}$ Mahrátta, 21 January 1906, from Weekly Report, L\R\5\161
} 
Such articles provided fodder for Tilak's ongoing battle with Gopal Krishna Gokhale, the leader of the Moderate wing in the Indian National Congress. Cleverly avoiding any appearance of a personal attack, Tilak instead let Devoy's paper speak for him. When Gokhale announced his belief that Ireland would achieve Home Rule within a year, the Gaelic-American scoffed that Anglo-Indian administrators had "grossly deceived" him, citing Ireland's forty-year history of agitation and Britain's equally long refusal to capitulate. The paper was insistent that "the rights and the hopes of the Irish and the Indian peoples are the same, and if one of them could be cheated out of their rights, as any and every British Government is capable of doing, the other would be defrauded in an equal measure." ${ }^{, 673}$ In a sign that Irish-Americans—-like the Irishrecognized the pressing need to present a united front against the British Government, the Gaelic-American rallied Tilak's readers: "We say to the Indian people then, go on with your Swadeshi movement."

Despite the fact that the Swadeshi movement monopolized the columns of the Indian nationalist press, editors on the subcontinent continued to monitor imperial policy abroad. In a move which set them apart from the anti-Semitic ravings of the Irish and Irish-American nationalist press, journalists in India repeatedly pronounced their outrage at Russian treatment of the Jews. The Madras-based Jaridah-i-Rosgar despaired that a Christian nation was so demonstrably lacking in humanity as to permit such "brutal murder," while the Calcutta-based Bharat-Mitra directed its scorn not merely at Russia,

\footnotetext{
${ }^{673}$ Mahrátta, 16 December 1906, from Ibid.

${ }^{674}$ Ibid.
} 
but at Britain and all of the European powers. ${ }^{675}$ The paper found it disturbing that Prime Minister Gladstone had spoken out so vehemently at the time of the Turkish atrocities in Armenia, yet "now that the Jews are being so mercilessly massacred in Russia, no Power thinks it worth its while to utter a single word." ${ }^{, 676}$ In a similar vein, the Hitavarta scoffed at the European powers whose "love of humankind would be overflowing" if such a massacre had happened in Asia, but who refused to criticize the Christian Czar, in a show of "political impartiality."677 Once again, the Indian nationalist press had not only brought to its readers' attention atrocities committed by a European power, but also had shown it was unafraid to make religion - and specifically Christianity - a critical issue in its analysis of Britain's imperial policy.

Nor were the attacks on the Jews the only foreign focus of the Indian nationalist press. Whereas the Boer War had ended in 1902, three years later life for the Indian population in the Transvaal had not improved. Equally galling to the native press were the generous overtures made by the British to the Boer population, while loyal India was perennially neglected and taken for granted. "The British pour milk into the Transvaal," charged the Swadesamitran, "while only water is given to the Indians."678 The InduPrakásh seized this opportunity to compare Britain's treatment of the Boers in the wake of the South African War with the treatment of its Indian subjects in a time of peace. The paper reminded its readers that the Boers had waged a bitter and violent three-year war in

${ }^{675}$ Jaridah-i-Rosgar, 18 November 1905.

${ }^{676}$ Bharat Mitra, 9 December 1905.

${ }^{677}$ Hitavarta, 24 June 1906.

${ }^{678}$ Swadesamitran, 3 May 1905. 
an attempt to oust the British from South Africa, only relinquishing their arms when the promise of future self-government was extended. By contrast, India had been compliant and loyal, and had "never once given an indication of a desire to put an end to Pax Britannica."679 Yet Britain had denied India even the hope of self-government, persistently alluding to internal divisions. The Indu-Prakásh rejected that rationale, claiming, "If Indians are unfitted for self-government on account of racial antipathies and conflicting class interests, so are the white colonists of South Africa — and especially so the uncompromising Boers. ${ }^{, 680}$ In the eyes of many Indian nationalist journalists, tension on the subcontinent between Hindus and Muslims paled in comparison to the Boers' intolerant treatment of Indian immigrants and African natives.

Irish advanced-nationalists also directed their gaze overseas. This tumultuous period coincided with the appearance of the Republic, a new Irish publication as pronounced in its anti-imperialism as it was in its adherence to the doctrine of Sinn Féin. Founded and edited by Belfast-born Bulmer Hobson - a member of the Irish Republican Brotherhood and one of the future founders of the Irish Volunteers - the Republic had a run of five months before merging with the Irish Peasant. ${ }^{681}$ During the paper's brief existence, it not only trumpeted the cause of Irish independence, but also of Indian and Egyptian nationalism. Hobson accused British officials of mischaracterizing the Indian Swadeshi movement as "a virulent outbreak of disaffection, engineered by underbred

\footnotetext{
${ }^{679}$ Indu-Prakásh, 27 April 2005.

${ }^{680}$ Ibid.

681 Together with Denis McCullough, Hobson founded the Dungannon Clubs, which celebrated the exploits of the Volunteers of 1782. The Dungannon Clubs would ultimately merge with Arthur Griffith's Cumann na $n$ Gaedheal, to form Sinn Féin. Although a staunch advanced-nationalist and an organizer of the Irish Volunteers, Hobson was opposed to open rebellion, a position which prompted the leaders of the Easter Rising of 1916 to kidnap Hobson, so that he could play no role in aborting the Rising.
} 
agitators for selfish ends," and assured his readers that Indian and Irish nationalists shared the same noble cause. ${ }^{62}$ Just as Hobson embraced the vision of an Irish Ireland, so he continuously espoused the possibility of Indian unity.

Like Hobson, Arthur Griffith commandeered the pages of his paper to argue for an Irish Ireland, but never ceased to exploit occurrences abroad. The paper included an "Over the Frontier" column that featured extensive coverage of India and regularly excerpted Indian papers. The names of prominent Indian nationalist leaders - from B.C. Pal to Surendranath Banerjea-were given pride of place in the column, with Griffith's paper reporting dutifully on Pal's monster meetings - patterned after O'Connell's — and the crowning of Banerjea as the "King of Bengal." 683 Griffith paid particularly close attention to India's quest for national education, reprinting the objectives of the National Council of Education in Bengal. ${ }^{684}$ On 8 September 1906, Griffith updated his readers on the progress of the Swadeshi movement, noting that the very idea of a united India was once deemed "too absurd for consideration."685 "But," explained the editor, "the forcible partition of Bengal, the defeat of a white power by a united people of another colour, and the rise and spread of the Swadeshi movement, have all served in bringing together the various races and the differing creeds of India in a national league of brotherhood. ${ }^{686}$

\footnotetext{
${ }^{682}$ Principles of the Swadeshi Movement," Republic, 9 May 1907.

${ }^{683}$ Sinn Féin, 8 September 1906.

${ }^{684}$ Sinn Féin, 29 September 1906. Among the objectives listed were an insistence on national control of primary, secondary, and collegiate schooling; the maintenance of high standards of qualification; and the inclusion of textbooks printed in the vernacular.

685 “Over the Frontier,” Sinn Féin, 8 September 1906.

${ }^{686}$ Ibid.
} 
In Griffith's estimation, it was that very unity that the British Empire most feared, with the editor alleging that imperial policy was specifically designed to set the factions against each other. "The fundamental of British rule in India," charged Griffith, "is to keep the Indians from uniting for their country by accentuating their religious differences." ${ }^{\circ 87}$ Thus, "Mahommedans and Hindus have been set at each other's throats in India as Protestant and Catholic have been set at each other's throats in Ireland." ${ }^{688}$ Writing in the Republic, Bulmer Hobson supported Griffith's allegations, pouring scorn on a Times of London article which Hobson claimed was written in "the spirit of deliberate murder and incitement to civil war." ${ }^{\prime 69}$ The editor decried the fact that the Muslim Indian "is patted on the pat and told that he can, and he will, clear the peninsula of Hindoo editor and Swadeshi patriot alike." ${ }^{690}$ Desirous of attributing the roots of such sectarian strife solely to British meddling in Ireland and on the subcontinent, Arthur Griffith chose to ignore the fact that Indian and Irish politicians were often complicit in alienating their fellow countrymen. Tilak's brand of nationalism was decidedly religious in nature, and his emphasis on Hindu mythology and ritual certainly proved detrimental to hopes of national unity, whereas Ulster's Protestant politicians regularly characterized Home Rule as "Rome Rule." As a native of Belfast, Bulmer Hobson was more aware of the enmity directed at Irish Catholics by Ulster Protestants.

Griffith, however, opted to ignore the homegrown voices of division, preferring to focus only on the exciting new homegrown Indian resistance movement that paralleled 687 “Over the Frontier," Sinn Féin, 15 September 1906.

${ }^{688}$ Ibid.

689 “Sinn Féin in India,” The Republic, 7 March 1907.

690 
his own Sinn Féin. The editor seemed to take inordinate glee in surmising what Swadeshi might portend for the future of the British Empire, predicting, "Against the enlightened and united India which we see being born, the power of England will be as

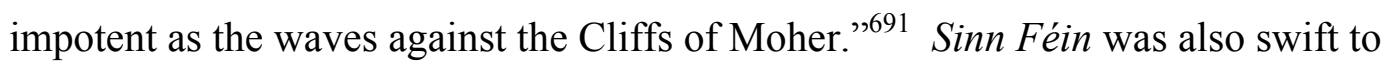
acknowledge India's efforts to hobble British banking, noting, "Almost simultaneously with the awakening of a desire in Ireland for the foundation of a National Bank, a movement has begun in India for the same purpose. ${ }^{.692}$ Given Griffith's desire to revitalize Irish industry, he sought to emphasize the economic success of the Swadeshi movement, noting the "appreciable rise" in wages for local laborers. ${ }^{693}$

Envisioning Indian patriots as brothers-in-arms who were new to the struggle against the British Empire, Arthur Griffith frequently imparted advice to his Indian counterparts. Upon the election of a new Liberal government, Griffith warned that the Indian National Congress would be as easily duped as the Irish Parliamentary Party into believing that the Liberals had the good of the Indian and Irish people at heart. He particularly took aim at John Morley, the new Secretary of State for India, asserting that just as Morley had kept the Irish "in subjection to the interests of British Liberalism," his policies would keep the Indian populace "in economic subjection to the Lancashire manufacturers." ${ }^{694}$ The Mahrátta reprinted the Gaelic-American's advice that Morley was not to be trusted, stating, "The Liberal hypocrites and occult influences that dominate the British policy alike in Ireland and India are using the reputation of Mr. Morley to

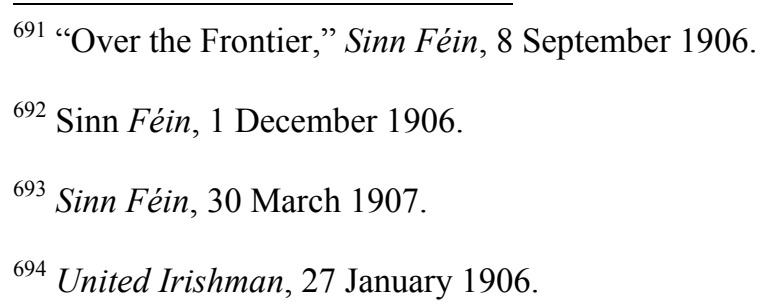


deceive the Indian people as they are using that of Mr. Bryce in Ireland. These two people have no more power to turn British policy in Ireland or India into channels of right or justice than a New York street sweeper." ${ }^{, 695}$

The Irish and Irish-American assessment of Morley may have been unnecessarily harsh. As Chief Secretary for Ireland (1886, 1892-95) and Secretary of State for India (1905-1910), Morley was uniquely positioned to assess the impact of repressive legislation on Her Majesty's subjects, and was often the Liberal voice of reason. When, in 1907, Lord Minto, Viceroy of India, suggested the necessity of muzzling the native press to prevent the spread of disaffection in the Indian Army, Morley observed that a press law always seemed to be the first recourse of a ruler confronted with unpleasantness. ${ }^{696}$ Making his own preference clear, he stated, "My principle is that a press law should come, not first, but last." ${ }^{\prime 697}$ Minto had confided his concerns to Morley, opining, "We must remember that we are dealing with the press of a country entirely different in its standard of morality and civilization than the countries of the Western world." ${ }^{, 698}$ While acknowledging that the press was exacerbating an already quarrelsome pay dispute in the Indian Army, Morley was still moved to demand of Minto, "How would a clumsy press law—and all such laws have been in every country,_-Austria,

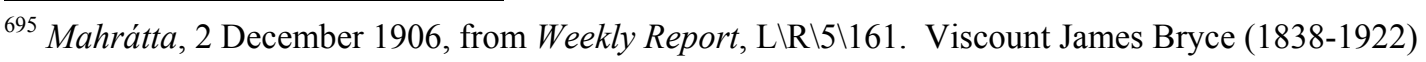
served as Chief Secretary to Ireland from 1905-06 before being named British Ambassador to the United States in 1907.

${ }^{696}$ Morley to Minto, 8 August 1907, Letters to the Earl of Minto, Vol.II, 1907. MSS EUR D 573/2, OIOC, British Library.

697 Ibid.

${ }^{698}$ Minto to Morley, 3 July 1907. Letters to Viscount Morley, MSS EUR D 573/12, OIOC, British Library.
} 
Russia, Ireland,_-clumsy, inflammatory, provocative — suppress all this?"699 Minto was particularly incensed over the importation of pamphlets from the American-based Irish nationalist organization, Clan-na-Gael, that had been "supplying large numbers of their abominable publications to the Native troops."700 Failing to understand how a new press law could combat American publications, Morley replied acerbically, "Surely it does not need an American leaflet to make a soldier, Native or European, think that his pay should be raised.",701

A series of press prosecutions in Bombay gave Minto pause, and he confided in Morley that he fully understood there was "considerable risk in muzzling free expression of opinions," but feared the dangers of an unfettered press "preaching of rebellion amongst an ignorant and inflammable population."702 Minto's characterization of the Indian masses not only recalled the words of Council member Alexander Arbuthnot during deliberations on the 1878 Vernacular Press Act, but also those of Chichester Fortescue denigrating Irish peasants at the time of the 1870 Peace Preservation (Ireland) Act. Nearly three decades after the passage of the Vernacular Press Act, there continued to exist among many quarters of officialdom a disdain for the Indian intellect and a fear of an excitable Indian temperament. For those reasons, Minto was insistent that the Government should not allow Bipin Chandra Pal "to stomp the country preaching

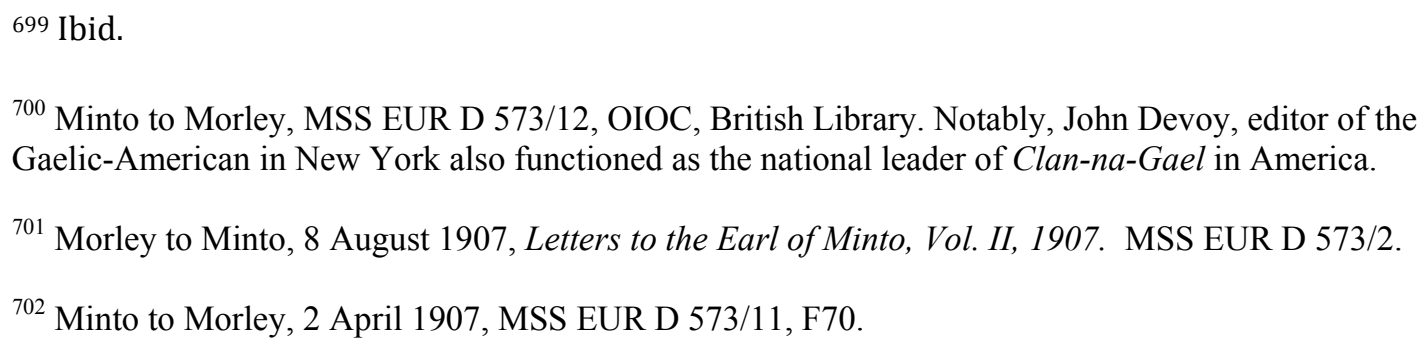


sedition," whereas Morley professed himself somewhat perplexed by the Government of India's surveillance and prosecution of Pal. ${ }^{703}$ In 1906, B.C. Pal and Aurobindo Ghose had founded the newspaper Bande Mataram, focusing on issues of Indian nationalism and Indian unity. Within a year, Ghose was sole editor, as Pal devoted himself to public speaking, addressing the topics of Swadeshi and swaraj at monster meetings throughout India. ${ }^{704}$ In Pal's estimation, the desire for swaraj was a direct result of the British mishandling of the boycott: "It is by hatching out boycott eggs that they have produced self-government youngsters. ${ }^{, 705}$ Alarmed by what they perceived as Pal's inflammatory rhetoric, the Government of India tracked Pal's movements throughout Madras, attending his public appearances and transcribing his speeches, which were not only printed in Bande Mataram, but were also sold as pamphlets. Notwithstanding the surrounding furor, Morley termed Pal's offenses trivial and irrelevant and the Government's actions "foolish and impolitic."706 Tried for sedition in British law courts, Pal appropriated a notable Sinn Féin tactic by refusing to give evidence. ${ }^{707}$

Aware of the growing power of the native press, the Government enacted the Newspapers (Incitement to Offences) Act, 1908, a bill that proscribed the publication of

\footnotetext{
703 Ibid.

${ }^{704}$ In 1908, Pal resumed editorial duties.

${ }^{705}$ A Collection of Speeches Delivered by B.C. Pal after His Return to Calcutta from the Madras Presidency. IOR/L/PJ/6/841, File 56, OIOC, British Library.
}

706 Morley to Minto, 26 September 1907, Letters to the Earl of Minto, Vol. II, 1907. MSS EUR D 573/2.

\footnotetext{
${ }^{707}$ In his memoir, The Indian Struggle (Bombay: Asia Publishing House, 1964), Subhas Chandra Bose recalled that Sri Aurobindo Ghosh, "had compared this policy with the policy of the Sinn Féin Party." Coverage of Pal's non-cooperation, coupled with his conviction and sentence monopolized both native and Anglo-Indian newspapers throughout the summer and fall of 1907.
} 
any commentary which functioned as an incitement to violence, and mandated the confiscation of any offending paper's printing press. The 1908 Newspapers (Incitement to Offences) Act was the Government of India's most efficient attempt, yet, to rid the country of troublesome journalists. Officials convicted Shivram Mahadev Paranjape, the editor of the Kál, on charges of sedition—stemming from articles on bomb-throwingand imprisoned Paranjape for a period of nineteen months. The Government, moreover, took the opportunity to ban the Kál outright, and used the powers of the new act either to suppress other papers convicted of sedition or drive the most subversive papers underground. ${ }^{708}$ Whereas, in private, Morley may have questioned the 1908 law, he ultimately defended the legislation in public. In a speech delivered to the House of Commons, Morley underscored the power of the native press to persuade and influence. "The native press aims at creating, not reflecting, public opinion," charged Morley, adding, "The violent language of the native press is no new thing, but it grows worse from year to year." ${ }^{709}$ The speech pointedly identified the Bombay and Bengal Provinces as the hotbeds of sedition, but noted that the Punjab and United Provinces were showing disturbing signs of following suit, and credited the "foolish" speeches of Bipin Chandra Pal as stirring up anti-imperialist protest from "feather-headed students.",710

Pal's speeches may have drawn the attention of authorities, but it was his arrest that caught the attention of Griffith and his fellow Irish journalists, who admired Pal's

\footnotetext{
${ }^{708}$ Sedition Committee Report. Calcutta: Superintendent Government Printing, India, 1918, 49.

${ }^{709}$ Speech Delivered by the Right Honourable John Morley, M.P., Secretary of State for India, in the House of Commons on the Indian Budget, 6 June 1907. Cited in Sydney Smith, the Edinburgh Review (Volume 206, Harvard College Library) 278-279.

${ }^{710}$ Ibid.
} 
campaign of resistance. As in Bal Gangadhar Tilak's 1897 trial for sedition, what was at issue was the very definition of disaffection. Pal wondered aloud how the British Government had managed to conflate disaffection with a simple want of affection. The Indian leader disputed that claim, arguing that Indian people might not love their British rulers, but the absence of warmth did not necessarily imply a desire to plot against the Raj. When the Indian leader advocated a policy of "benevolent indifference," Griffith's paper applauded the phrase, noting that India's emphasis on home-made products and national industry was the equivalent of Ireland's own Sinn Féin policy. ${ }^{711}$ By the edition of 30 March 1907, the paper was referring to the Swadeshi movement as the Indian Sinn Féin movement. Ireland's provincial papers followed suit, with the Anglo-Celt asserting that the Sinn Féin movement "is being propagated in the various provinces." "712 The paper was equally proud that progress of the Sinn Féin program in Ireland was being monitored by the native press in India. ${ }^{713}$

Tilak also continued to make pointed and favorable comparisons between the two movements. Referring to India as "a second edition of Ireland, subject, of course, to local limitations," the editor of the Mahrátta exhorted his countrymen not only to emulate Irish obstructionism in Parliament, but also to gain an appreciation for the Sinn Féin policy. ${ }^{714}$ Tilak, in fact, was insistent that observation of Griffith's program would prove instructive and enlightening. Though he recognized that Ireland was pursuing a similar course to

\footnotetext{
${ }^{711}$ Sinn Féin, 2 March 1907.

${ }^{712}$ Anglo-Celt, 27 July 1907.

713 Ibid.

${ }^{714}$ Mahrátta, 24 February 1907, from Weekly Report, L \R \5\162.
} 
that of India's nationalists, Tilak could not resist a pointed reference to the fact that "Ireland is largely represented in the British Parliament while India is not."

A lack of representation in Parliament was not the only thing that differentiated British treatment of Ireland and India. In addition to passing the Newspapers (Incitement to Offences) Act in 1908, a mere two years later the Legislative Council of the GovernorGeneral of India passed the 1910 Press Act, which mandated licensing of all newspapers and strengthened the bonds of censorship, forbidding the promotion of sedition or disaffection, "whether by inference, suggestion, allusion, metaphor, implication, or otherwise. ${ }^{, 716}$ It did not escape the notice of India's nationalist journalists that two separate pieces of legislation were enacted to rein in the native Indian press in a time of peace, while no such laws were devised to deal with the Irish press during this same period. The fact, moreover, that India's nationalist press had been, for the most part, demonstrably loyal during the Boer War and Boxer Rebellion-urging the Empire to deploy Indian troops - while the Irish nationalist press liberally boasted of its disloyalty and mounted anti-recruitment campaigns was yet another troubling indication of an enduring imperial double standard.

Sinn Féin and Swadeshi were domestic movements; yet, their impact was felt far beyond the borders of their origin. The very fact that the Indian Swadeshi movement and the Irish Sinn Féin policy were moving forward concurrently garnered international attention, from Britain's allies as well as rivals. Regardless of the fiery oratory that

\footnotetext{
${ }^{715}$ Ibid.

${ }^{716}$ Indian Press Act, 1910; Internet; available at http://awmin.nic.in/legislative/textofcentralacts/1910.pdf; accessed on 30 March 2013.
} 
accompanied their arrival on the scene, both programs were, by and large, peaceful in design and execution - a fact that did not stop editors from depicting the Irish and Indian participants as combatants engaged in a war with the Empire over the very soul of a nation. It was not by happenstance that the socialist leader James Connolly entitled his two-part polemic on the state of the subcontinent as "The Coming Revolt in India.,"117 Implicit in the title was the prediction that Britain's treatment of her supposed "jewel in the crown" could only result in violence. Connolly hinted, moreover, that violent acts might be the most effective method of compelling the British to capitulate, reminding readers that it was the terror engendered by the Fenian conspiracy that hastened the disestablishment of the Church, and "the smoke and fire of the Indian mutiny" that precipitated - in the same year - the establishment of universities in Bombay, Calcutta, and Madras. ${ }^{718}$

Connolly refuted the argument that India had benefited by British rule, claiming that sixteen million natives had died of starvation and that the Government spent only one-fiftieth of its revenue on education in India, whereas it spent almost twice that amount on education in England and Scotland. "India is regarded by its alien rulers as a huge human cattle farm to be worked solely in the interest of the dominant class of another nation," claimed Connolly. ${ }^{719}$ Embracing the Marxist characterization of religion as the "opium of the people," Connolly expressed particular disdain for the role of

\footnotetext{
${ }^{717}$ James Connolly, "The Coming Revolt in India II: Its Political and Social Causes" The Harp, February 1908. Internet; available at http://www.marxists.org/archive/connolly/1908/02/india2.htm; accessed on 17 February 2013.

${ }^{718}$ Ibid.

${ }^{719}$ Ibid.
} 
religion in Indian affairs, charging, "Religion, in fact, in India, as everywhere else, loses by being identified with the forces of a tyrannical government." ${ }^{, 720}$ Connolly warned that India could expect charity—but not justice—from Britain, as government coffers would reap no benefit from meting out justice. Together with other Irish and Indian nationalist editors, Connolly was issuing a challenge to his readers to take their destiny into their own hands, by whatever means necessary. Independence would not be magnanimously granted; it must be wrested from the Empire, by word and by deed.

Accordingly, Irish nationalist editors continued to point to Indian struggles as further evidence of Britain's tyranny, while Indian national editors alluded to Britain's continued subjugation of Ireland — despite teasing with the promise of Home Rule—as proof of the Government's hypocrisy. These years were critical to the development of the nationalist movement in India, Ireland, and Irish-America, the last of which was now actively funneling funds - and weapons - across the sea to those who had formed the physical force movement. Indeed, the Kál, edited by firebrand Shivram Mahadev Paranjape, made no attempt to downplay its delight that the Gaelic-American "has now hit upon a noteworthy expedient of at once promoting its own circulation and increasing the sale of Mauser rifles," by promising a new rifle to those who enlisted thirty new subscribers." ${ }^{, 721}$ Foreshadowing the embrace of physical force by some of India's own nationalists, the Kál indicated its approval of the Irish-American newspaper's scheme:

\footnotetext{
${ }^{720}$ James Connolly, "A Contribution to the Critique of Hegel's Philosophy of Right," in DeutschFranzösische Jahrbücher, 7 \& 10 February 1844; Paris; Internet: available at http://www.marxists.org/archive/marx/works/1843/critique-hpr/intro.htm; accessed on 27 March 2013. James. Connolly, "The Coming Revolt in India."

${ }^{721}$ Kál, 18 May 1906.
} 
"Excess of oppression suggests secret methods of emancipation.",722 The Vihari was equally bold in its pronouncement. "We commend to our countrymen the methods of resistance, active and passive, resorted to by the Irish in dealing with the British Government.",723 The paper unfavorably contrasted the "resolute" Irish nationalists with their "weak" Indian counterparts, and recommended that the people of India stop trembling and instead follow the Irish example. "The Irish who are tired of English oppression," pronounced the Vehari, "are proud of becoming martyrs in the cause of their country's emancipation., ${ }^{, 724}$ Leaving no doubt where its sympathies lay, the paper referred to the "Empire of the Feringees" as hell on earth. ${ }^{725}$ This level of anti-imperial hyperbole marks the passage from what was once gentle criticism, to a new and unabashed attack, and reflects the mounting frustration of India's nationalists.

Nationalist journalists in both countries recognized the propaganda value of charting each success — however small—of other British subjects struggling to escape from imperial domination. If they were to ask their readers to make sacrifices, it was not only helpful, but also necessary to characterize their national quest as part of a larger movement within the Empire. Thus, Tilak, Paranjape, Banerjea, Griffith, Connolly, and their colleagues celebrated their common cause, taking every opportunity in these years to underscore the similarity of methods, attitudes, and objectives. In an editorial that signaled Tilak was moving away from the agenda of the Indian National Congress, the

\footnotetext{
${ }^{722}$ Ibid.

${ }^{723}$ Vehari, 7 January 1907.

${ }^{724}$ Ibid.

${ }^{725}$ Vehari, 28 January 1907. "Feringee" had long been in use as the Hindu word to describe Europeans.
} 
Mahrátta — traditionally the more moderate of Tilak's two papers—suggested that constitutional methods had reached the end of their effectiveness. The paper recommended that its readers direct their attention to "the course of a self-reliant agitation conducted in Ireland, itself," where Tilak was convinced "we may gain more practical enlightenment than by marking the effects of the policy of obstruction pursued by Irish members in Parliament." ${ }^{, 726}$ Tilak's pronouncement about the futility of relying on the Indian National Congress indicated that India's Extremists were determined to pursue a parallel course to Griffith and the Irish advanced-nationalists.

Notwithstanding this period of marked solidarity, nationalist editors could not sustain the heightened sense of comradeship, and the strong awareness of common cause would dissipate in the coming years. When next India looked to Ireland, it would be in the aftermath of the 1916 Easter Rising, when boycott and obstructionism had given way to revolutionary violence. In the intervening years, matters within their own borders would compel journalists to look inward for solutions, not outward for support. Swept up in the vitality of their respective new movements, and immersed in the day-to-day operation of their newspapers, editors in both countries pounded away at their recurring themes: revival of native industry, reverence for ancient heritage, and insistence on a program of national education that emphasized Irish or Indian culture and history.

Yet even as editors sought to focus on their domestic agendas, tensions among the nations of Europe were coming to a head, and would once more impress upon journalists the necessity of looking beyond their own borders. The Irish advanced-nationalist press had railed as America forged an understanding with Britain, the Indian nationalist press

${ }^{726}$ Mahrátta, 24 February 1907. 
had despaired as Britain forged an alliance with Japan, and editors in both countries had rejoiced at finding themselves allied in the struggle for independence. Now, however, it seemed the world was a jumble of alliances, and that tangled web would determine the course of the coming conflict. The nationalist press in India and Ireland would need to decide to whom they owed their own loyalties.

At the turn of the century, as the Boxer Rebellion and the Boer War seized the attention of Europe and the world, advanced-nationalist newspapers in Ireland had viewed the British Empire with a pronounced animosity, whereas Indian nationalist journalists had time and again pledged their oath of fealty. Now, buoyed by the promise of the Third Home Rule bill coming to a vote in Parliament, the Irish Parliamentary Party was in the ascendancy once more, as constitutional methods finally appeared ready to produce the desired results. If Britain would finally grant some measure of independence to Ireland, perhaps the long-standing ill-feelings would dissipate and eventually disappear. By contrast, the voices of discontent in India had grown louder and more strident, driven into hardened opposition by the Empire's hapless handling of drought, famine, and plague; by its suppression of the rights of Indians in the Transvaal; its refusal to allow Indians a greater role in governing their own country; and its systemic neglect of India as Britain sought to expand its Empire. "It seems that England will not stop till she is completely ruined by her rage for unjust acquisition and the unjust maintenance of the Empire," warned the Kál. ${ }^{727}$ As the world hurtled toward war in August 1914, Irish nationalists clung to hope, sensing a new beginning; Indian nationalists saw only the beginning of the end.

${ }^{727}$ Kál, 24 April 1908. 


\section{Conclusion}

The British Empire was seemingly at its zenith—and yet it had never been more vulnerable. The war in South Africa had not only depleted its manpower, but also had revealed its weaponry as inadequate, and its tactics as outdated. The Boxer Rebellion had fractured the coalition of the European powers, while the Russo-Japanese War and, in particular, Germany's naval build-up, had impressed upon Britain the vital necessity of forming and renewing strategic alliances. Monitoring it all from the safety of the home front and eagerly snapping up every piece of information leaked from the War Office were the journalists of the Irish and Indian nationalist press - keen to use British conduct in the wars as ammunition in their own internal battles with the Empire. Notwithstanding the brilliant oratory of those in the Indian National Congress and the Irish Parliamentary Party, the leaders of the two nationalist movements could not maintain forward momentum without the will of the people. Therefore, for the nationalist movement to prosper, the editors moved forward on twin fronts, not only laying down the foundations of a viable national program, but also framing the debate in ways that would be both meaningful and accessible to the masses.

To reach the common people, few avenues proved as direct, as effective, and as impervious to attack as a newspaper column. A well-written editorial was a weapon to which the Empire was extraordinarily susceptible, as it could not easily protect itself without appearing to dishonor the tradition of a free press. Editors such as Bal Gangadhar Tilak (Mahrátta, Kesari), Surendranath Banerjea (Bengalee), and Shivram Mahadev Paranjape (Kál) in India and Arthur Griffith (United Irishman, Sinn Féin), 
James Connolly (Workers' Republic), and D.P. Moran (The Leader) in Ireland, as well as the exiled Irishman John Devoy (Gaelic-American) in America understood the power of the pen to provoke outrage or evoke a sympathetic response. They designed their newspapers to appeal equally to the intellect and the emotions. Under the guise of educating their readers, editors shaped the form and content of their weekly lessons by carefully selecting the evidence presented and the manner in which it was delivered.

The reciprocity of ideas, the parallel tracks of Irish and Indian nationalism, and the emergence of a pantheon of extraordinary visionaries who brilliantly straddled the worlds of politics and journalism mark this as a particularly telling era in the long history of the British Empire. At the heart of the increasingly contentious relationship between the British Government and the members of the nationalist press in both Ireland and India was the fact that elements in both countries were chafing under British rule, eager to shed their status as subjects of the British crown and to assert their independence. What journalists sought was evidence to support their claim that the status quo was no longer acceptable. With a seemingly relentless series of conflicts and conflagrations that spanned several continents, the British Empire supplied the substance. The nationalist journalists of Ireland and India provided the style.

War clearly benefited nationalists in both Ireland and India, delivering unexpected dividends in the form of Britain's transparent motives and surprisingly inept handling of the crises. Coverage of the imperial wars offered an unequaled opportunity to place before Indian and Irish readers proof of Britain's expansionist obsession and often brutal military tactics. The Irish and Indian nationalist press artfully manipulated news from 
South Africa and China, cherry-picking those items that supported their ideology and invigorated their base.

A side-by-side examination of Irish and Indian coverage of Britain's imperial conflicts identifies comparable strategies adopted by Irish and Indian nationalist journalists, but also underscores the glaring differences in the methods and motives of those particular factions. The Irish nationalist press criticized the Empire almost wholly on political grounds, perennially supporting the cause of Britain's enemies. From the outset, the nationalist press in Ireland felt little loyalty to the British Empire, and consciously made every attempt to use the Boxer Rebellion and the Boer War to its advantage. In particular, the advanced-nationalist press—crusading for nothing less than full Irish independence — eagerly relayed to their readers every British misstep, setback, and reversal. The reporting was colored by animosity and driven by passion for the cause of Irish nationalism. That Britain prosecuted the war in South Africa by adopting methods that earned it the disapproval of much of the civilized world merely played into the hands of the press in Ireland, giving it added ammunition with which to continue its journalistic assault. Pro-Boer, Pro-Boxer, and anti-British in its rhetoric, the Irish advanced-nationalist press, led by Arthur Griffith, reveled in its disloyalty—at the same time claiming protection under the freedom of press granted to journalists as British subjects. Irish nationalist journalists used the imperial wars to highlight, as well, Britain's flawed management of its colonies and cavalier treatment of its subjectsexhorting its readers to wrest control of Ireland from the grasping hands of the Empire, and decide, for good or for ill, their own destiny. 
The Indian native press was much slower to exploit the wars, and, indeed, made a great show of expressing its loyalty to the Empire. Whereas the Irish press predetermined the manner in which it would cover the war, events in China and South Africa proved the determining factors in how the Indian native press reported the hostilities. Journalists used the imperial wars not only to underscore Britain's mishandling of its empire, but also to focus attention on the religious and, in particular, the underlying racial prejudice which influenced the course of British policy. The Empire's willingness to use native troops in China while simultaneously refusing to deploy them in South Africa — a White Man's War—was exactly the evidence journalists needed to bolster their assertion of an imperial double standard. The behavior of western missionaries in China gave rise to suspicions about Christianity's claim to brotherhoodsuspicions which were deepened as the Indian native press watched two Christian nations engage each other in battle in the Transvaal. The destruction of farms and natural resources and the internment of women and children handed Indian editors the necessary tools to present a portrait of an Empire without conscience, adrift from its liberal moorings. Britain's handling of its imperial wars convinced Indian nationalists that Home Rule must be the endgame - the reward for decades of selfless dedication and loyalty to the British war effort in China, South Africa, and, ultimately, the battlefields of the First World War. Those same wars convinced Irish advanced-nationalist journalists that Home Rule for Ireland was no longer the panacea once imagined; only full independence — a free Ireland for the Irish—would suffice.

Given the obvious contrast in their approaches to the wars, the nationalist press in Ireland and India might have remained isolated cases--were it not for the British 
propensity to view them through the same filter of suspicion. Britain saw only the similarities - attempting to apply the lessons of Ireland to a strikingly different situation on the subcontinent. Ireland's advanced-nationalists professed no loyalty to the Empire, launched protracted anti-recruitment campaigns in their papers, and used their columns to urge rebellion. India's nationalist papers expressed loyalty, argued for the inclusion of Indian troops within the British Army, and, until after the Great War, sought to remain within the Empire. Yet, imperial authorities repeatedly enacted legislation designed to censor and suppress native Indian papers and imprison their editors - with the Newspapers (Incitement to Offences) Act 1908 and the 1910 Indian Press Act enacted in times of peace. Britain's conviction of its racial superiority was the foundation for its condescension toward India's uneducated masses, and fueled a belief that even the mildest hint of anger or disaffection from the nationalist press could spark a revolution.

Issues of time and place played an integral role in British treatment of the Irish and Indian nationalist press. The British Government could afford to be more tolerant of Irish anti-imperial rhetoric, owing to the ease and speed with which officials could read and suppress those newspapers. Authorities frequently seized hold of Arthur Griffith's United Irishman in the Post Office, halting its circulation throughout Dublin and the Irish countryside. In India, however, the Marathi-language Kesari and Kál had circulated throughout the Bombay Presidency and beyond, long before Government of India translators could deliver an English translation of Tilak's or Paranjape's inflammatory editorials. Always one step behind, the Empire overcompensated with aggressive prosecutions, a stance criticized by Parliamentarians at home in England, who had the advantage of being several thousand miles away from Indian agitation. By contrast, as a 
series of Press Laws and Coercion Acts indicate, Westminster always grew animated over the prospect of a rebellion just across the Irish Sea. Fortunately for the officials, easy access to the offending Irish papers - published in English—enabled Dublin Castle to short-circuit their influence in a timely fashion. That felicitous pattern, however, would soon change.

The very fact that Britain felt compelled to rein in the anti-imperial rhetoric of the Irish and Indian nationalist press provides tangible evidence that the Government acknowledged and feared the effectiveness of the war coverage. Imperial response showed a marked change over time, with officials resorting to methods of coercion and repression that proved diametrically at odds with Britain's standing as a beacon of liberalism. Increasingly embroiled in an international rivalry with Germany, and beset by domestic strife in the form of labor disputes and women's suffrage, the British government was ill-equipped to cope with the barrage of criticism launched from the pens of Irish and Indian nationalists. Despite its tortuous attempts to muzzle its critics, the British government proved unsuccessful in meeting the challenge presented by the combined journalistic assault. Ultimately, Britain's reactionary response to Irish and Indian criticism of its military policy served to unite journalists in a common cause. The nationalist press in Ireland and India not only continued to exploit the imperial wars as a means of furthering their agendas, but also ingeniously used each other's tales of resistance to buttress their own nationalist platforms and establish a global context for their shared nationalist aspirations. 


\section{Epilogue}

A Serbian nationalist had assassinated Archduke Ferdinand of Austria, Kaiser Wilhelm was preparing to turn the full weight of Germany's formidable military force in support of its allies, and all of Europe was on the verge of mobilization. Yet, in the heat of the long summer of 1914, it was not world war that preoccupied the British Government; it was the very real possibility of civil war. At the heart of the tension was the Government of Ireland Bill—long-delayed legislation that would establish an Irish Parliament, eliminate the reign of Dublin Castle, and grant Home Rule to Ireland. In the north of Ireland, Ulster's Protestants, led by firebrand Unionist Edward Carson, were incensed at the idea that the bill—which they derided as "Rome Rule" — would compel them to answer to Catholic nationalists in the south. ${ }^{728}$

With passage of the Act imminent, irate Unionists founded the Ulster Volunteers, a group that numbered in the hundreds of thousands by the summer of 1914. In contravention of a December 1913 proclamation prohibiting the importation of weapons into Ireland, the Ulster Volunteers illegally armed themselves with German guns - an act the Anglo-Celt characterized as "a deliberate device by the Carsonites to intensify the spirit of hatred towards Catholics in the ranks of the Protestant masses. ${ }^{, 729}$ Not to be

728 On September 28, 1912, Carson had been the first to affix his signature to the Solemn League and Covenant - the Ulster Covenant - in which the 237,368 male signatories pledged "to stand by one another in defending for ourselves and our children our cherished position of equal citizenship in the United Kingdom and in using all means which may be found necessary to defeat the present conspiracy to set up a Home Rule parliament in Dublin." Women were not permitted to sign the Covenant, but 234,046 instead signed a Declaration, aligning themselves with the position of Ulster's men. Cited in Public Record Office of Northern Ireland Historical Topic Series; Internet; available at http://www.proni.gov.uk/

historical_topics_series_-_05_-_ulster_s_solemn_league_and_covenant.pdf; accessed on 20 March 2013.

729 “The North-East’s Outlook,” Anglo-Celt, 1 August 1914. 
outdone, advanced nationalists formed the Irish Volunteers and sought to import their own cache of 900 Mauser rifles. ${ }^{730}$ In India, the nationalist press lost no time weighing in on the Irish crisis. "It would be by no means an exaggeration," proclaimed the Bengalee, "to say that the eyes of the whole world are just now turned towards Ireland."731

For a British Government confronting the very real possibility of civil war in Ireland over the impending passage of Home Rule, therefore, the timing of the First World War must have seemed almost fortuitous. Rather than face the wrath of an outraged Edward Carson and his fellow Ulster Unionists, who were growing increasingly militant, the Government tabled indefinitely all discussion of the Government of Ireland Bill — as well as the equally problematic Amending Bill desired by the Unionistsclaiming that the first order of business must be the war effort. Apparently struck by the gravity of the moment, Irish Parliamentary Party leader John Redmond delivered a stirring Westminster speech that not only offered Irish loyalty to the Government, but also held out the prospect of harmony between Nationalist Catholics and Protestant

\footnotetext{
${ }^{730}$ The landing of weapons at Howth precipitated a confrontation with the Metropolitan Police and Scottish Borderers and ended with a Dublin riot and the shooting deaths of three civilians in what would come to be known as the "Massacre of Bachelor's Walk." Nationalist headlines screamed in bold letters, "Dublin Outrage" and "Dublin Horror," furnishing readers with dramatic accounts of the shooting and offering heated condemnations of the Ulster Volunteers and of the ineptitude of the Government. "Dublin Outrage," Donegal News, 1 August 1914; "The Dublin Horror, Kildare Observer, 1 August 1914. "The shooting in Dublin and the consequent loss of life," proclaimed the Review of Reviews, "is only one more proof-were proof needed - that Castle government is as stupid and as irresponsible as ever." "The Progress of the World," in The Review of Reviews; Aug 1914; 50, 296; British Periodicals pg. 85. To the nationalist press, the fact that Ulster's importation of arms met with no Government resistance only highlighted British hypocrisy, and underscored the urgency of obtaining — by whatever means possible - an independent Ireland.

${ }^{731}$ Bengalee, 14 July 1914. Even before word of the Dublin shooting, native editors viewed the moves of Ulster's Unionists with disdain. "If a hundredth part of what is being done in Ulster had been done in India, there would have been numerous deportations without trial," asserted the Hitavadi, adding, "But no one has dared to injure even a single hair of Sir Edward Carson's head." Hitavadi, 26 July 1914. This was not merely a case of India's nationalists criticizing Irish Unionists and identifying with Irish nationalists; the Hitavadi was calling attention to the relatively mild treatment meted out to the Empire's Irish subjects, while its Indian subjects - including those in the press - remained objects of suspicion and mistrust.
} 
Ulstermen. "I say to the Government that they may tomorrow withdraw every one of their troops from Ireland," declared Redmond, adding, "if it is allowed to us, in comradeship with our brethren in the North, we will ourselves defend the coasts of our country."732 The vision of nationalists and unionists uniting in support of Britain was a welcome prospect for the beleaguered British Government, which only hours before had feared it would become embroiled in two wars.

From across the Empire came an immediate outpouring of support for Britain in its hour of need. Nationalist editors in both India and Ireland lifted their voices in a rousing chorus of patriotic fervor, expressing gratitude for being part of the British Empire, offering aid and assistance to the war effort, and pledging undying loyalty. Redmond's speech found its way into the columns of the Freeman's Journal, the official organ of the Irish Parliamentary Party, as well as the Irish Independent, the Connaught Telegraph, the Anglo-Celt, and the Nenagh News, while the Southern Star expressed confidence that the speech "was certain to make for a really united Ireland, peaceful, prosperous and free."733 The Gujarati exclaimed, "Never in the history of British India has there been such an outburst of enthusiastic and fervent loyalty to His Majesty's Government as has been witnessed during the last few days." ${ }^{, 734}$ For its part, the Indu Prakash took a moment to proclaim a special pride in the performance of the Indian press, which, it boasted, had "acquitted themselves brilliantly in educating the public into

\footnotetext{
732 "Statement by Sir Edward Grey," Hansard Parliamentary Debates, House of Commons, 3 August 1914, series 5, vol 65, cc 1809-32. Internet; available at http://hansard.millbanksystems.com/commons/1914/ aug/03/statement-by-sir-edward-grey\#S5CV0065P0_19140803_HOC_71; accessed on 22 May 2013.

${ }^{733}$ Southern Star, 8 August 1914. By 1919, the Southern Star, together with the Meath Chronicle, Sligo Champion, and Nenagh Guardian, among others provincial papers, had shifted their allegiance, and made a practice of distributing Sinn Féin notes.

${ }^{734}$ Gujarati, 16 August 1914.
} 
perceiving clearly the great issues of the war"-reminding its readers that Britain was the "champion of European Liberty.,"735 The Kesari, however, sought to qualify that position, insisting that "the duty of newspapers consists not only in publishing news but also in commenting on them." "736 Tilak's words harkened back to his manifesto of 1902, in which he had stated unequivocally that the role of the press was not merely to parrot official pronouncements, but also to uncover the shades of grey with which every imperial issue seemed to be imbued.

For all their avowed loyalty, Indian journalists did not absolve the British Empire of its continued neglect and misuse of Indian troops - a complaint which had first been voiced in the Boer War. When informed that the combined forces of all of the European powers totaled eighteen million, the Amrita Bazar Patrika offered the observation that "this number could have been supplied to England by India alone, if the former had but pursued a policy of greater trust and less suspicion towards her greater dependency.",737 More pointedly, Tilak's Kesari found Britain's attitude perplexing, given the contrast between Irish and Indian attitudes toward the Empire. "It is an undisputed fact," asserted the paper, "that India is more loyal than Ireland which has offered to protect itself from the enemy."738 "But," the Kesari continued, "Indians cannot evince their loyalty beyond speaking and thinking of it. They cannot give any physical help. This is very

\footnotetext{
${ }^{735}$ Indu Prakash, 18 August 1914.

${ }^{736}$ Kesari, 25 August 1914.

${ }^{737}$ Amrita Bazar Patrika, 10 August 1914.

${ }^{738}$ Kesari, 11 August 1914.
} 
regrettable."739 Once again, Britain's refusal to repay Indian allegiance with anything other than suspicion and condescension rankled the nationalist press.

In Ireland, the initial effusive display of loyalty must have been heartening to Government ministers who had steeled themselves to expect screeds of anti-British venom. Appearances, however, were not what they seemed. Bubbling beneath the surface of this display of Irish patriotic unanimity lay the roiling discontent of the Irish advanced-nationalist movement, whose editors were conspicuous by their absence from the outburst of flag-waving ardor. The radical press had proliferated during the preceding decade, with twenty-three Dublin papers identifying themselves as socialist, associated with the Sinn Féin movement, or linked to the Irish Republican Brotherhood at the onset of the war. ${ }^{740}$ Just as British forces hunkered down in the trenches seeking safety from German artillery, so did the British Government find itself under sustained attackbombarded by a relentless barrage of Irish criticism, launched from the pens of Arthur Griffith, James Connolly, D.P. Moran, and their compatriots.

The question of how the Irish advanced-nationalist nationalist press would cover Britain's entry into the war had preoccupied the British Government, which had sought a solution in the Defence of the Realm Act (DORA), enacted in August 1914. The Act empowered the Government to wield the weapons of censorship and suppression "to prevent the spread of false reports or reports likely to cause disaffection to his

\footnotetext{
${ }^{739}$ Ibid.

${ }^{740}$ DORA (CO 903/19/1: Chief Secretary Intelligence Reports, 1915. Table on circulation of seditious newspapers, fl.40.), cited in Benjamin Z. Novick, "DORA, Suppression, and Nationalist Propaganda." In New Hibernian Review. (Vol 1, No. 4, Winter 1997), 42.
} 
Majesty."741 Within the first few months of the war, however, the British Government found itself harried and harangued by an increasingly entrenched group of journalistic adversaries. In addition to the always problematic newspapers of Griffith and Connolly, a new crop of papers had sprung into being, all taking aim at the British lion. The Irish Freedom, founded in 1910, proved adamant in its anti-imperial stance, declaring that "even if this paper stood alone in Ireland against all forces of stupidity and imbecility which cluster around the new imperialism, even if we stood alone against a people gone mad, we would still stand for right." ${ }^{, 72}$ Characterizing the British Empire as a menace to the peace of the world, the Irish Volunteer, the official organ of the Irish Volunteers, exhorted its readers to break free of Britain's hold. “Our only safety, our only hope of national development and national honour," decreed the paper, "lies in cutting ourselves free from the last tie that binds us to English Imperialism." ${ }^{, 73}$ Leaving no doubt as to where its loyalties resided, the Irish Volunteer concluded, "Our only path to the glorious and happy Ireland of our aspirations lies through the downfall of the British Empire., ${ }^{, 74}$ In particular, the anti-recruiting articles, leaflets, pamphlets, and posters sponsored by the advanced-nationalist press seriously undercut Britain's ability to enlist the necessary quota of Irishmen. In a pointed and fairly obvious attempt to curtail these anti-imperial exploits, Parliament voted to amend the 1914 Defence of the Realm Act, making interference with army recruitment an actionable offense. The patent

\footnotetext{
${ }^{741}$ Defence of the Realm Act 1914 (DORA); Internet; available at http://www.nationalarchives.gov.uk/ pathways/firstworldwar/first_world_war/p_defence.htm; accessed on 9 March 2013.

${ }^{742}$ Irish Freedom, September 1914.

${ }^{743}$ Irish Volunteer, 7 November 1914.

${ }^{744}$ Ibid.
} 
responsibility of the Irish advanced-nationalist press for subverting recruitment raised the ire of British politicians and Ulster Unionists, who rose to their feet in the House of Commons and the House of Lords to demand that the Government take immediate action against the "grossly seditious" Irish press. ${ }^{745}$ The Earl of Desart berated those Irish newspapers whose articles and widely circulated leaflets were of "the most violent character against England," and produced a "considerable" effect on recruiting ${ }^{746}$ of special concern were the Irish Volunteer, the Irish Freedom, the socialist Irish Worker, and Arthur Griffith's Sinn Féin - four papers singled out by the Times of London for their relentless anti-recruiting efforts.

The tactics of the advanced-nationalist press were not merely a distraction for the British Government; they dramatically impeded the British war effort-hampering its ability to recruit in Ireland and forcing it time and again to divert its attention from the European front. The ability of the advanced-nationalist press to derail Government efforts at recruitment in Ireland was particularly galling, given that Ireland had for decades contributed overwhelmingly to the ranks of Britain's imperial soldiers. Not only did the advanced-nationalist press deter young Irishmen from enlisting in the British army; but also they encouraged them to take up arms and fight for Ireland against the

\footnotetext{
745 "Power to Make Regulations as to the Defence of the Realm," Hansard Parliamentary Debates, House of Commons, 25 November 1914, series 5, vol 68, cc 1269-1270. Internet; available at http://hansard.millbanksystems.com/commons/1914/nov/25/clause-1-power-to-make-regulations-as-to; accessed on 22 May 2013.

746 "Recruiting in Ireland," Hansard Parliamentary Debates, House of Lords, 24 November 1914, vol 68, cc 117-118. Internet; available at http://hansard.millbanksystems.com/lords/1914/nov/24/recruiting-inireland; accessed on 22 May 2013.
} 
Empire. ${ }^{747}$ Socialist James Connolly was unrelenting in his stance concerning the war, arguing that the conflict would do nothing to benefit the Irish worker. "If you are itching for a rifle, itching to fight, have a country of your own," argued Connolly, "better to fight for our own country than for the robber empire. If ever you shoulder a rifle, let it be for Ireland." ${ }^{\text {748 }}$ Parliamentary supporters of the Government responded to such anti-imperial rhetoric with splenetic attacks on the writers, urging the Press Bureau to censor and suppress the offending organs, including the Gaelic-American, copies of which Rowland Hunt claimed were circulated in the thousands "for the purpose of poisoning the minds of Nationalists in Ireland against the British Government." ${ }^{, 79}$ Pushed to the limit, the Government announced its intentions to suppress the offending newspapers.

Accordingly, Dublin Castle sent its emissaries to shut down the operations of Griffith's Sinn Féin, together with the Irish Freedom, Irish Volunteer, and Irish Worker.

In Ireland, Arthur Griffith met the news of the impending crackdown with his customary sang-froid, convinced that the Government would never obtain a conviction. "If it prosecutes us without packing the jury, we win; if it prosecutes us and packs the

\footnotetext{
${ }^{747}$ The Irish Volunteers published their wartime manifesto in the Dublin-based Irish Review, in which they stated unequivocally that any Irishman who elected to fight for either Britain or Germany was a slave. Only the Irishman "who knows he should be under Irish rule and no other" was capable or worthy of obtaining freedom. Among those affixing their names to the Manifesto were several contributors to Irish advanced-nationalist organs, including Patrick Pearse, Piaras Beaslai, Sean MacDiarmada, and Bulmer Hobson of the United Freedom, newly founded in 1910. Hobson also moonlighted as the Dublin correspondent for John Devoy's Gaelic-American, which kept up a persistent anti-Empire drumbeat throughout the war.

748 “Our Duty in This Crisis," Irish Worker, 8 August 1914.

749 “Seditious Press (Ireland)," Hansard Parliamentary Debates, 26 November 1914, vol. 68, cc1290-1291. Internet; available at http://hansard.millbanksystems.com/commons/1914/nov/26/seditious-press-ireland; accessed on 22 May 2013.
} 
jury, we win," Griffith taunted. ${ }^{750}$ The editor expressed confidence in the righteousness of his position, avowing, "No unpacked Irish jury will brand felon on the brow of those who have stood between the youth of Ireland and the plot to immolate them in England's interest." ${ }^{, 751}$ For all his bravado, however, Arthur Griffith knew he could not combat the wartime operation of Dublin Castle and elected to shutter the Sinn Féin, putting an end to the series of aggressively anti-British articles for which he had become both renowned and infamous.

Not one to be deterred by prosaic regulations, Arthur Griffith rebounded from the suppression of the Sinn Féin with an ingenious plan to circumvent the Defence of the Realm Act. Scissors and Paste was a wickedly clever invention comprised solely of previously-published excerpts from other newspapers. The one fillip was that Griffith artfully interspersed among breaking news of the war carefully chosen past pronouncements from key political figures that undermined their current stance on the conflict - thus providing subversive editorial commentary without writing a single original word. Although the journal was technically not in violation of the Defence of the Realm Act, Under-Secretary of State for War Harold Tennant informed Westminster that the paper consisted of cuttings "selected for their derogatory references to the cause or military operations of the Allies and for their praise of the methods and successes of

\footnotetext{
${ }^{750}$ Sinn Féin, 14 November 1914.

${ }^{751}$ Ibid.
} 
the enemy." ${ }^{\text {752 }}$ Scissors and Paste soon followed the Sinn Féin newspaper into oblivion. Within months, Griffith was publishing yet another newspaper, Nationality.

While Arthur Griffith used the opening months of the war to exhort his countrymen to thwart the British war effort, his counterpart in India, Bal Gangadhar Tilak, took a different approach to the war, as did most of the Indian nationalist press. Newly released from a six-year prison term for sedition just prior to the onset of the war, the editor of the Mahrátta and the Kesari chose not to impede the war effort, and even traveled the country in support of war bonds. Indeed, in his articles and speeches, the editor joined the chorus of Indian nationalist organs who had urged support of the Empire, in the belief that the British Government would ultimately have to reward Indian cooperation.

Yet, Tilak also realized that the nationalist movement in India had foundered during his incarceration. Not only had the Government of India dampened Tilak's influence by imprisoning him for six years, but also authorities had permanently removed as an agitator Tilak's fellow Chitpavan Brahmin, Shivram Mahadev Paranjape. Once considered Poona's two "most influential journalists," Tilak and Paranjape both

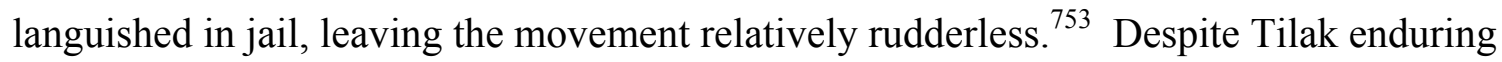
the longer prison sentence, the Kesari and Mahrátta managed to survive their editor's incarceration, while the Kál did not outlive Paranjape's much shorter absence. Already subject to the 1908 Newspapers Act and the 1910 Press Act, the onset of the First World

\footnotetext{
752 “Irish Newspapers (Defence of the Realm Act)," Hansard Parliamentary Debates, House of Commons, 10 March 1915, series 5, vol 70, cc1424-1425W. Internet; available at http://hansard.millbanks.com/ written_answers/1915/mar/10/irish-newspapers-defence-of-the-realm-act; accessed on 22 May 2013.

${ }^{753}$ Sedition Committee Report. Calcutta: Superintendent Government Printing, India, 1918, 13.
} 
War brought yet another restrictive bill. In March 1915, the Legislative Council passed the Defence of India Act, 1915, roughly equivalent to the Defence of the Realm Act in its aim and scope. Like that 1914 legislation, the Defence of India Act, 1915 singled out the press for heightened scrutiny, threatening the suppression of newspapers, confiscation of machinery, and imprisonment of offending editors.

Undaunted by his lengthy imprisonment—or by the parade of new regulationsTilak sought to infuse the nationalist cause with new energy and purpose. As the war dragged on, Tilak became convinced of the foolishness of delaying the next move until the end of hostilities, in the possibly vain hope that the British would show their appreciation in some vague and indeterminate manner. At the end of the year, the Indian National Congress and the All-Indian Muslim League, which had been founded in 1906, convened for a joint session in December 1915, signing the Lucknow Pact, which promised Hindu-Muslim cooperation in attaining rights for the Empire's Indian subjects. Building on that newfound sense of unity, Tilak joined with Annie Besant- the leader of the Theosophical Society—as well as the Muslim leadership, to found the All India Home Rule League in 1916. Its aim was simple: if India was going to continue to support the British Empire with men, money, and natural resources, it expected the Empire to grant self-government at the conclusion of hostilities. Always aware of Tilak's enormous influence with the masses, the Government of India once again charged the editor with sedition, for a series of lectures he delivered in 1916. Although Tilak's first two sedition trials in 1897 and 1908 had ended in convictions, Muhammad Ali Jinnahwho would become Pakistan's first Governor-General—successfully defended Tilak on the 1916 accusations, and the Bombay High Court dismissed all charges against Tilak. 
1916 would, of course, prove to be a watershed year for Ireland, as well. Tired of waiting for the enactment of the Third Home Rule Bill, and no longer content to accept any form of government that required the country to remain part of the Empire, advanced-nationalists moved the country inexorably towards the Easter Rising. The advanced-nationalist press in Ireland was the single most effective weapon in the arsenal of those seeking Irish independence. Indeed, the evidence for the integral role played by that particular segment of the Irish press is reflected in the number of journalists who actively participated in the 1916 Easter Rising. Among those executed for their involvement were James Connolly (Workers' Republic), Patrick Pearse (Irish Freedom), Sean MacDiarmada (Irish Freedom); and Roger Casement (Irish Freedom). Significantly, so great was his reputation for exhorting his countrymen to press for independence that Dublin Castle ordered the arrest and imprisonment of Arthur Griffith (Nationality), although the editor played no part whatsoever in the Easter Rising.

At the war's end, the Government of India would continue to focus on the power of the nationalist press to promote disaffection, with Justice Rowlatt presiding over the Sedition Committee. The Committee sought to investigate acts of terrorism-most notably in Bengal and in the Punjab - as well as possible links to the governments of Germany and Russia. Passed in spite of vocal opposition lodged by Indian members of the Supreme Legislative Council, the Rowlatt Act dramatically curtailed civil liberties, and effectively extended wartime legislation to a country then at peace. Quickly dubbed the "Black Acts" by outraged nationalists, the legislation drew the ire of the Indian nationalist press, as well as the attention of Arthur Griffith's Nationality and other Irish advanced-nationalists organs, which noted a more than passing resemblance to the 
wartime Defence of the Realm Act. The press took an even more ardent interest in the 1919 British massacre of unarmed Indian civilians at Amritsar — an event which immediately followed on the heels of the Rowlatt Act's passage. ${ }^{754}$ One year later, the shooting of Irish civilians in Croke Park earned the event the dubious sobriquet of the Irish Amritsar. ${ }^{755}$ Once again, editors in India and Ireland looked across the sea and found common cause in their treatment at the hands of the Empire.

Britain emerged from the First World War victorious, but bloodied and reeling. It had engaged the foe on several continents, but, almost as tellingly, it had also battled adversaries on the home front_-journalists critical of its imperial alliances, recruitment policy, and military strategy. In Ireland, the Empire had responded with surveillance and suppression — which led neither to an increase in British army recruits, nor even to the cessation of anti-imperial rhetoric. Rather, the draconian measures prompted heightened resentment and renewed attacks in the advanced-nationalist press of an even more aggrieved and aggressive tone. By the same token, Britain's refusal to acknowledge the validity of the criticism emanating from the Indian nationalist press materially hampered its war effort. The failure to acknowledge the contributions of India, compounded by a persistently paternalistic attitude toward Indian troops and a pattern of regarding its

\footnotetext{
${ }^{754}$ On 13 April, Brigadier-General Reginald Dyer marched his troops into the enclosed area known as the Jallianwala Bagh, in which 20,000 Indians were assembled. Without warning, Dyer ordered his men to open fire on the unarmed crowd. 1,650 rounds later, 1,500 Indians had been wounded and 379 were dead. Indian sources have disputed the numbers, claiming that the number of dead approached one thousand. For more on how Ireland's advanced-nationalists exploited events at Amritsar, see Richard Davis, "India in Irish Revolutionary Propaganda." Journal of the Asiatic Society of Bangladesh. Volume XXII, No. 1, April 1977, 66-89.

${ }^{755}$ On 21 November 1920, a day that came to be known as "Bloody Sunday," the Royal Irish Constabulary mowed down fourteen civilians - including one footballer - at a Gaelic Football match in Dublin's Croke Park. That same morning, the assassination of twelve members of British Intelligence had been carried out on the orders of Michael Collins, the leader of the Irish Republican Brotherhood.
} 
Indian subjects with suspicion would have grave consequences for future relations between India and the Empire.

Over the course of two decades, while the Empire eyed new territory, shifted alliances, and fought from the Transvaal to the trenches of France, the nationalist press in India and Ireland waged their own war of words. They used the columns of the newspapers to launch ideological trial balloons, school and drill their recruits, and whet their readers' appetite for the ultimate prize: independence. For Irish and Indian nationalist editors, it became a simple case of publish or perish—and their combined journalistic output inflicted wounds that would fester and refuse to heal. There would be no retreat, no end of hostilities until the Empire lowered the Union Jack, raised the white flag of surrender, and retired from the field. 


\section{BIBLIOGRAPHY}

\section{Primary Sources}

\section{Papers in the Indian Office Records, British Library}

Grant Duff Collection. MSS EUR F 234.

Morley Collection. MSS EUR D 573/1-5; 573/7-25.

Curzon Collection. MSS EUR F 111-112.

Lytton Collection. MSS EUR E 218/146-147.

Papers of Sir Richard Temple. MSS EUR F 86/214.

Political and Secret Records. IOR \L\PS $\backslash 7 \backslash 316$.

Public and Judicial Papers. IOR $\backslash L \backslash P J \backslash 6 \backslash 484,488$.

\section{Papers in the British National Archives, Kew, England}

Cabinet Records. CAB 37

Dublin Castle Papers. CO 904, 906.

Records of the Colonial Office: Ireland. CO 903.

\section{Papers in the National Library of Ireland, Dublin}

Arthur Griffith Papers

William O’Brien Papers

Native Newspapers in the India Office Records, British Library

Annual Report on the Native Press of the Bombay Presidency for the Year 1903. $\mathrm{L} \backslash \mathrm{R} \backslash 5 \backslash 158$

Annual Report on the Native Press of the Bombay Presidency for the Year 1904. $\mathrm{L} \backslash \mathrm{R} \backslash 5 \backslash 159$.

Reports on the Native Papers - Bengal Presidency. L $\backslash \mathrm{R} \backslash 5 \backslash 25-41$.

Reports on the Native Papers - Bombay Presidency. L $\backslash \mathrm{R} \backslash 5 \backslash 133$; 136; 156-169.

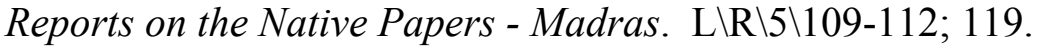

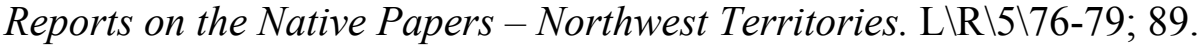

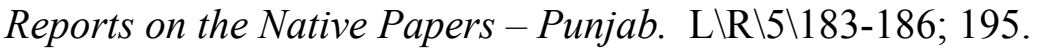

\section{Irish Newspapers}

An Geadhal

Anglo-Celt (Cavan)

Connaught Telegraph

Donegal News

Evening Herald (Dublin)

Fianna Fail (Dublin)

Freeman's Journal (Dublin)

Ireland (Dublin)

Irish Freedom (Dublin)

Irish Independent (Dublin)

Irish People (Dublin) 
Irish Volunteer

Irish World (Dublin)

Irish Worker (Dublin)

Kildare Observer

Meath Chronicle

National Volunteer

Nenagh Guardian

Nenagh News

Scissors and Paste (Dublin)

Sinn Féin (Dublin)

Sligo Champion

Southern Star (Cork)

The Irishman (Dublin)

The Leader (Dublin)

The Nation (Dublin)

The Republic (Dublin and Belfast)

The Spark (Dublin)

United Irishman (Dublin)

Workers' Republic (Dublin)

\section{Indian Newspapers}

Advocate of India

Akhbár-i-'Am

Amrita Bazar Patrika

Aronodaya

Aryavart

Bande Mataram

Bangabandhu

Bangavasi

Baroda Vatsal

Basumati

Bengalee

Bhála

Bharat Mitra

The Champion

Charu Mihir

Civil and Military News

Darussaltanat and Urdu Guide

Decca Prakush

Deshabhakta

Gujarati

Gujarati Punch

Gurakhi

Guzerat Mitra

Hablul Mateen 


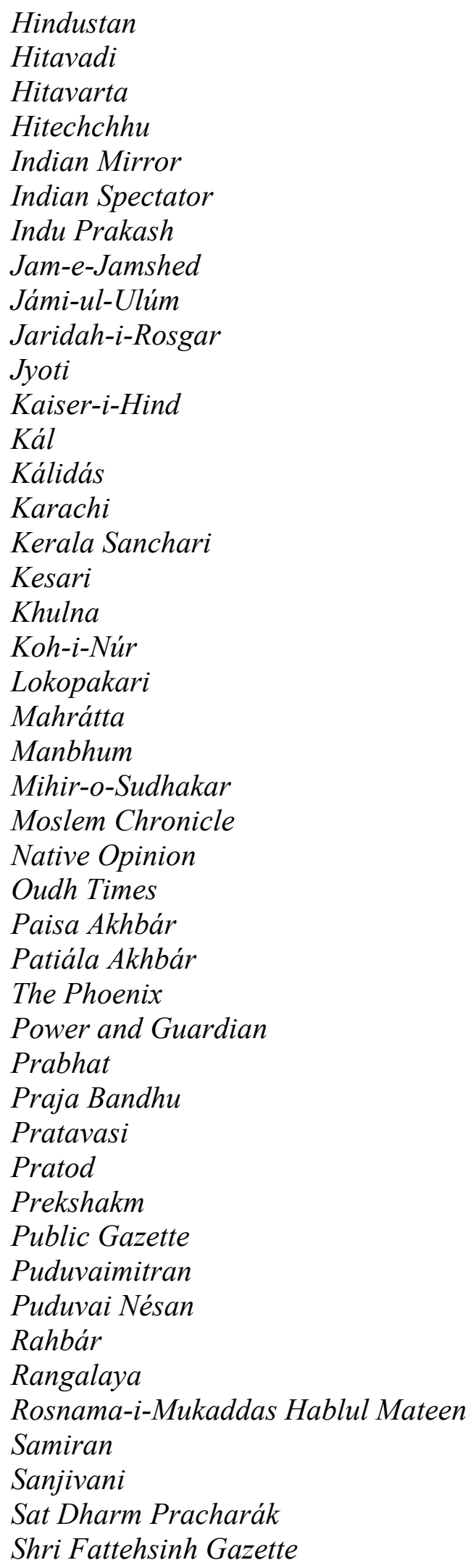




\author{
Shri Savaji Vijay \\ Siálkot Paper \\ Som Prakash \\ Swadesamitran \\ Swadesi \\ Taj-ul-Akhbár \\ Tripura Hitaishi \\ Vehari \\ Vrittanta Chintamani \\ Vrittanta Patrika \\ Wakil \\ Wasir-i-Hind
}

\title{
English Newspapers
}

Daily Express

Evening Telegraph

Manchester Guardian

The Nation

Times (London)

\section{American Newspapers}

Gaelic-American (New York)

New York Daily Tribune

New York Herald

New York Times

\section{Australian Newspapers}

Launceston Examiner

\section{Government Publications}

Admiral Togo's official report of the attack on Port Arthur, 10 February 1904. Internet. Available at http://www.russojapanesewar.com/togo-aar1.html. Accessed on 14 February 2013

The British Monarchy, Internet. Available at http:/www.royal.gov.uk/HMTheQueen/ TheQueenandspecialanniversaries/Factfiles/QueenVictoriasDiamondJubilee.aspx; Accessed on 27 January 2013.

Council of India. Act No. IX of 1878. An Act for the better control of Publications in Oriental Languages.

Defence of the Realm Act 1914 (DORA); Internet; Available at http://www.nationalarchives.gov.uk/pathways/firstworldwar/first_world_war/ pdefence.htm. 
Emperor vs. Bal Gangadhar Tilak on 9 November, 1916. Bombay High Court. Internet. Available at http://indiankanoon.org/doc/1188602/. Accessed on 11 March 2013.

Far Eastern Staff Plans of Naval Operations, 1901-3. Internet. Available at http://www.russojapanesewar.com/russ-game.html. Accessed on 14 February 2013.

Hansard Parliamentary Debates, Series 3, Volumes 200, 242 (1870).

Hansard Parliamentary Debates, Series 4, Volume 77 (1899); $78-79$ (1900).

Hansard Parliamentary Debates, Series 5, Volumes 65, 68 (1914); 70 (1915)..

. Public General Acts. 33 and 34 Victorie. London, 1870. The Peace Preservation Act (Ireland Act), 1870.

Indian Penal Code. Internet. Available at http://indianlawcases.com/ActIndian.Penal.Code,1860-1557. Accessed on 25 December 2012.

Indian Press Act, 1910. Internet. Available at http://lawmin.nic.in/legislative/ textofcentralacts/1910.pdf. Accessed on 30 March 2013.

Ray, R.E.A. Report on the Activities of Terrorists in Bengal. Calcutta: Bengal Government Press, 1931.

Samanta, Amiya K., ed. Terrorism in Bengal: A Collection of Documents on Terrorist Activities from 1905-1939. Six volumes. Calcutta: Government of West Bengal, 1995.

Sedition Committee Report. Calcutta: Superintendent Government Printing, India, 1918.

Treaty of Nanking, 1842, Article I. Internet. UCLA International Institute. Available at http://www.international.ucla.edu/article.asp?parentid=18421. Accessed on 13 March 2013.

\section{British and Irish Periodicals}

Bodkin, M. McD. "Why Ireland is Disloyal," in Fortnightly Review. December 1902, Volume 72. Reprinted in British Periodicals, 1019-1027.

Brayden, W.H. "Press Prosecutions in Ireland." In The Speaker: The Liberal Review. May 4, 1901. Reprinted in British Periodicals, 132-134. 
Griffin, Lepel. "South Africa and India." In The Nineteenth Century and After: A Monthly Review. May 1902. Volume 51. Reprinted in British Periodicals, 706715 .

H.C. "Some Indian Questions." In The Speaker: The Liberal Review. Sep 20, 1902.Reprinted in British Periodicals, 649-650.

Howorth, Henry H. "Our Indian Troops." In The Nineteenth Century: A Monthly Review. January 1900, Volume 47. Reprinted in British Periodicals, 36-40.

Irish Volunteers, "Manifesto to the Irish Volunteers." In The Irish Review. Vol. 4, No. 42. Sep.-Nov., 1914, 281-286.

Rees, J.D. "The Native Indian Press." In The Nineteenth Century and After: A Monthly Review. May 1901. Volume 49. Reprinted in British Periodicals, 817-828.

Sen, A.P. "Does English Education Breed Sedition in India?" In Westminster Review, August 1902, Volume 158. Reprinted in British Periodicals, 168-178.

TRUTH. "Why the Native Press Should Be Licensed." In Calcutta Review. January 1900. Volume 110, Pg. 219. Reprinted in British Periodicals, 130-151.

"The Progress of the World," in The Review of Reviews; Aug 1914; 50, 296; British Periodicals, pg. 85.

\section{Miscellaneous Published Material}

Banerjea, Surendranath. Address to the Eleventh Congress, Poona, 1895. In G.A. Natesan, Indian National Politics: Indian National Congress, 1898.

Besant, Annie. England, India, and Afghanistan and the Story of Afghanistan or Why the Tory Government Gags the Indian Press: A Plea for the Weak Against the Strong. Adyar, Madras, India: Theosophical Publishing House, 1931.

Bose, Subhas Chandra. The Indian Struggle. Bombay: Asia Publishing House, 1964,

Connolly, James. "British and Russian Imperialism I," in Workers' Republic, 3 September 1898. Internet. Available at http://www.marxists.org/archive/ connolly/1898/09/britrus1.htm. Accessed on 31 March 2013.

. "The Coming Revolt in India: Its Political and Social Causes." The Harp. Feb 1908. Internet. Available at http://www.marxists.org/archive/ connolly/1908/02/india2.htm. Accessed on 17 February 2013.

. "Home Rule Journalists and Patriotism: An Object Lesson." In Workers' Republic, 13 August 1898. Internet. Available at http://www.marxists.org/ archive/connolly/1898/08/journalists.htm. Accessed on 23 March 2013. 
. "Our Duty in This Crisis." Irish Worker. 8 August 1914. Internet. Available at http://www.marxists.org/archive/connolly/1914/08/dtycrsis.htm. Accessed on 17 February 2013.

. "Resolution of Sympathy with the Boer Republics." Workers' Republic. 20 June 1900. Internet. Available at http://www.marxists.org/archive /connolly/1900/06/ sympboer.htm. Accessed on 17 February 2013.

. "The Roots of Modern War," in Workers' Republic, 18 August 1898. Internet. Available at http://www.marxists.org/archive/connolly/1898/08/rootowar.htm. Accessed on 31 March 2013.

. "Sinn Fein, Socialism, and the Nation.” Irish Nation. 23 January 1909. Internet. Available at http://www.marxists.org/archive/connolly/1909/01/ sfsoclsm.htm. Accessed on 17 February 2013.

. "The South African War I." Workers Republic. 19 August 1899. Internet. Available at Available at http://www.marxists.org/archive/connolly/ 1899/08/sawar1.htm. Accessed on 17 February 2013.

. “The South African War II." Workers Republic. 18 November 1899. Internet. Available at http://www.marxists.org/archive/connolly/1899/11/sawar2.htm. Accessed on 17 February 2013.

. "Speech on War's Outbreak." Irish Worker. 5 September 1914. Internet. Available at http://www.marxists.org/archive/connolly/1914/09/wrsotbrk.htm. Accessed on 17 February 2013.

Dacosta, John. Remarks on the Vernacular Press Law of India, or Act IX. of 1878. London: W.H. Allen and Co., 1878.

Davis, Richard and Marianne Davis, eds. The Rebel in His Family: Selected Papers of William Smith O'Brien. Cork, Ireland: Cork University Press, 1998.

Davitt, Michael. Michael Davitt: May's Most Famous Son. Connaught Telegraph. Internet. Available at www.mayo-ireland.ie/Mayo/ News/ConnTel/ CTHistry/ MIDavitt.htm. Accessed 14 November 2003.

De Valera, Eamon. India and Ireland. New York: Friends of Freedom for India, 1920.

Devoy, John. Michael Davitt: from the Gaelic American. Edited by Carole King and W.J. McCormack. Dublin: University College Dublin Press, 2008. First reprinted in installments in the Gaelic American in 1906. 
Ghose, Aurobindo. Sri Aurobindo's Political Thought. Haridas Mukherjee, Uma Mukherjee, eds. Calcutta: K.L. Mukhopadhyay, 1958.

Griffith, Arthur. The Resurrection of Hungary: A Parallel for Ireland. Dublin: University College Dublin Press, 2003. First published 1904.

Heehs, Peter, ed. The Essential Writings of Sri Aurobindo. Delhi: Oxford University Press, 1998.

Henry, R.M. The Evolution of Sinn Fein. New York: B.W. Huebsch, Inc. 1920.

Kaiser Wilhelm. In Germany History Documents. Internet. Available at http://germanhistorydocs.ghi-dc.org/sub_document.cfm? document_id=755; Accessed on 22 May 2013.

Khan, Muzaffer Husain, B.A., LL.B., High Court, Vakil. The Indian Press Act, Act I of 1910. Calcutta: R. Cambray \& Co., 1919.

Macaulay, Thomas Babington. "Minute on Indian Education," Modern History Sourcebook. Internet. Available at http://www.fordham.edu/halsall/ mod/1833macaulay-india.asp. Accessed on 17 January 2013.

Martin, W.A.P. The Siege in Peking, China against the World. New York: F.H. Revell, 1900.

Marx, Karl. "A Contribution to the Critique of Hegel's Philosophy of Right." Deutsch-Französische Jahrbücher. Paris, 7 \& 10 February 1844. Internet. Available at http://www.marxists.org/archive/marx/works/1843/critiquehpr/intro.htm. Accessed on 27 March 2013.

Mitchel, John. Jail Journal of John Mitchel. Dublin: M. H. Gill \& Son, 1913.

Morley, Viscount. Speech Delivered by the Right Honourable John Morley, M.P., Secretary of State for India, in the House of Commons on the Indian Budget, 6 June 1907. Cited in Sydney Smith, the Edinburgh Review. Volume 206, Harvard College Library.

. Recollections. Two volumes. New York: The Macmillan Company, 1917.

Nehru, Jawaharlal. Nehru: The First Sixty Years, Two volumes, edited by Dorothy Norman. New York: The John Day Company, 1965.

O'Brien, William. Evening Memories. Dublin and London: Maunsel and Co., Ltd., 1920. 
. Irish Ideas. London: Longman's, Green, and Co., 1893.

. The Irish National Idea. Cork, Ireland: Printed and Published for the Cork

Young Ireland Society by Francis Guy, 70, Patrick Street, 1886.

. Recollections. New York: The Macmillan Company, 1905.

Spencer, Herbert. Letter to Kentaro Keneko, 26 August 1892. Internet. Available at http://praxeology.net/HS-LKK.htm. Accessed on 2 February 2013.

Stephens, James. Arthur Griffith, Journalist and Statesman. Dublin: Wilson, Hartnell, \& Co., 1924.

Swift, Jonathan. Drapier Letters. Internet. Available at http://www.usna.edu/ EnglishDept/ilv/swift.htm. Accessed 7 December 2003.

Tilak, Bal Gangadhar. "Address to the Indian National Congress, 1907." Modern History Sourcebook. Internet. Available at http:// www.fordham.edu /halsall/mod/1907/Tilak.html. Accessed 29 December 2004.

. Letters of Lokamanya Tilak. M.D. Vidwans, ed. Poona: Kesari Prakashan, 1966.

. Loyamanya Tilak in England, 1918-19: Diary and Documents. V.D. Divekar, ed. Pune: Tilak Smarak trust, 1997.

. Selected Documents of Lokamanya Bal Gangadhar Tilak. Four volumes. Ravindra Kumar, ed. New Delhi: Anmal Publications, 1992.

Webb, Alfred. The Autobiography of a Quaker Nationalist. Cork: Cork University Press, 1999.

\section{$\underline{\text { Secondary Sources }}$}

Anderson, Benedict. Imagined Communities. London and New York: Verso, 1983.

Barns, Margarita. The Indian Press: A History of the Growth of Public Opinion in India. London: George Allen \& Unwin, Ltd., 1940.

Bender, Jill C. "Mutiny or Freedom Fight? The 1857 Indian Mutiny and the Irish Press." In Simon Potter, Reporting the British Empire, c. 1857-1921. Dublin: Four Courts Press, 2004.

Brasted, Howard. "Indian Nationalist Development and the Influence of Irish Home Rule." Modern Asian Studies, Vol. 14, No. 1, 1980, 37-63. 
. "Irish Models and the Indian National Congress, 1870-1922." South Asia, Vol. 8. No. 1-2 (1985). 24-45.

Brillman, M. L. "A Crucial Administrative Interlude: Sir Antony MacDonnell's Return to Ireland, 1902-1904." In New Hibernia Review, Volume 9, Number 2. Summer 2005, 65-83.

. "Loyalty and Repeal: The Nation, 1842-46." Irish Journalism Before Independence: More a Disease than a Profession. Manchester: Manchester University Press, 2011.

Brown, Stephen J. The Press in Ireland: A Survey and a Guide. Dublin: Browne and Nolan Limited, 1937.

Butt, Ikram Ahmed. Lord Curzon and the Indian States, 1899-1905. AuthorHouse, 2006.

Cahill, Sean (Seán Ó Cathail). "The Politics of the Irish Language under the English and British Governments," In The Proceedings of the Barra Ó Donnabháin Symposium; Internet. Available at http://irelandhouse.fas.nyu.edu/docs/CP/

4172/0111-0126_PoliticsOfTheIrishLanguage.pdf. Accessed on 22 March 2013.

Cashman, Richard I. The Myth of the Lokamanya: Tilak and Mass Politics in Maharashtra. Berkeley: University of California Press, 1975.

Ch'en, Jerome. "The Nature and Characteristics of the Boxer Movement-A Morphological Study." Bulletin of the School of Oriental and African Studies. University of London, Vol. 23, No. 2, 1960.

Codell, Julie F., Ed. Imperial Co-Histories: National Identities and the British and Colonial Press. Madison: Fairleigh Dickinson University Press, 2003.

Colum, Padraic. Arthur Griffith. Dublin: Browne and Nolan Limited, 1959.

- Ourselves Alone: The Story of Arthur Griffith and the Origin of the Irish Free State. New York: Crown Publishers, Inc., 1959.

Cook, S,B. Imperial Affinities: Nineteenth Century Analogies and Exchanges Between India and Ireland. New Delhi: Sage Publications, 1993.

Crangle, John V. "Irish Nationalist Criticism of the Imperial Administration of India (1880-1884).”' Quarterly Review of Historical Studies (India), 1971/72, Vol. 40, No. 4: 189-194.

Crawford, Arthur. England Sympathizes with the Peoples of India: Opinions of The English \& Anglo-Indian Press, 1894-1899. London: William Fraser, 1901. 
Cumpston, Mary. "Some Early Indian Nationalists and Their Allies in the British Parliament, 1851-1906." English Historical Review, Vol. 76, No. 299 (Apr., 1961), 279-297.

Das, M.N. India under Morley and Minto. London: George Allen and Unwin, Ltd., 1964.

Davis, Richard. Arthur Griffith. Dundalk: Dungalgan Press for the Irish Historical Association, 1976.

. Arthur Griffith and Non-Violent Sinn Fein. Dublin: Anvil Books, 1974.

. "The Influence of the Irish Revolution in Indian Nationalism: The Evidence of the Indian Press 1916-22." South Asia, Vol. 9, No. 2 (1986), 55-68.

. "India in Irish Revolutionary Propaganda." Journal of the Asiatic Society of Bangladesh. Volume XXII, No. 1, April 1977, 66-89.

De Nie, Michael. "'Speed the Mahdi!' The Irish Press and Empire during the Sudan Conflict of 1883-1885." In Journal of British Studies, Vol. 51, No. 4. October 2012.

Echenberg, Myron J. Plague Ports: The Global Urban Impact of Bubonic Plague, 18941901. New York and London: NYU Press, 2007.

Edgerton, Robert B. Warriors of the Rising Sun: A History of the Japanese Military. Basic Books, 1999.

Esherick Richard. The Origins of the Boxer Uprising. Berkeley: University of California Press, 1987.

Ferguson, Niall. Empire: How Britain Made the Modern World. London: Penguin Books, 1983.

Fingerhut, Jeffrey. "Sahib and Sepoy: An Inquiry into the Relationship between the British Officers and Native Soldiers of the British Indian Army." Military Affairs, Vol. 18, No. 1 (Jan., 1984).

Foley, Tadgh and Maureen O'Connor, eds. Ireland and India: Colonies, Culture, and Empire. Irish Academic Press, 2006.

Fraser, T. G. "Ireland and India." In Keith Jeffery, ed. "An Irish Empire?" Aspects of Ireland and the British Empire. Manchester: Manchester University Press, 1996. 
Gilbert, Marc Jason. Lord Lansdowne in India: At the Climax of an Empire, 1888-1894, A Study in Late Nineteenth Century British Indian Policy and Proconsular Power. Los Angeles: University of California, 1978.

Glandon, Virginia. Arthur Griffith and the Advanced Nationalist Press, Ireland, 19001922. New York: Peter Lang, 1985.

Gopal, Ram. Lokamanya Tilak: A Biography. London: Asia Publishing House, 1956.

Gopal, S. British Policy in India 1858-1905. Cambridge: Cambridge University Press, 1965.

. The Viceroyalty of Lord Ripon, 1880-1884. London: Oxford University Press, 1953.

Gordon, Leonard A. Bengal: The Nationalist Movement 1876-1940. New York: Columbia University Press, 1974.

Hampton, Mark. Visions of the Press in Britain, 1850-1950. Urbana and Chicago: University of Illinois Press, 2004.

Hobbs, Andrew. "When the Provincial Press Was the National Press, c. 1836-1900;" Internet. Available at http://www.academia.edu/187659/ When_the provincial_press_was_the_nationalpress_c.1836-1900. Accessed on 27 January 2013.

Hobsbawm, Eric. The Age of Empire 1875-1914. Great Britain: Abacus Press, 1987.

Holmes, Michael and Denis Holmes. Ireland and India: Connections, Comparisons, Contrasts. Dublin: Folens, 1997.

Inamdar, N.R., ed. Political Thought and Leadership of Lokamanya Tilak. New Delhi: Concept Publishing Company, 1983.

Inglis, Brian. The Freedom of the Press in Ireland, 1784-1841. London: Faber and Faber, Ltd., 1954.

Jackson, Alvin. Home Rule: An Irish History, 1800-2000. Oxford: Oxford University Press, 2003.

James, Lawrence. Raj: The Making and Unmaking of British India. New York:

St. Martin's Griffin, 1997.

Jasanoff, Maya. Edge of Empire: Conquest and Collecting in the East 1750-1850. London: Fourth Estate, 2005. 
Jeffery, Keith, ed. “An Irish Empire?” Aspects of Ireland and the British Empire. Manchester: Manchester University Press, 1996.

Jog, N.G. Lokamanya Bal Gangadhar Tilka. Delhi: Ministry of Information and Broadcasting, Government of India, 1962.

Legg, Marie-Louise. Newspapers and Nationalism: The Irish Provincial Press, 18501892. Dublin: Four Courts Press, 1999.

Kabdebo, Thomas. Ireland and Hungary. Dublin: Four Courts Press, 2001.

Karmarkar, D.P. Bal Gangadhar Tilak: A Study. Bombay: Popular Book Depot, 1956.

Kaul, Chandrika. Media and the Empire. Houndmills, Basingstoke, Hampshire: Palgrave Macmillan, 2006.

Kee, Robert. The Green Flag. Three volumes. London: Penguin Books, 1972.

Keer, Dhananjay. Lokamanya Tilak: Father of the Indian Freedom Struggle. Bombay: Popular Prakashan, 1969. First published 1959.

Kennedy, Christopher M. Kennedy. Genesis of the Rising 1912-1916 : A Transformation of Nationalist Opinion. New York: Peter Lang, 2010.

Khan, Mohammad Shabbir. Tilak And Gokhale: A Comparative Study Of Their SocioPolitico-Economic Programmes Of Reconstruction. Ashish Publishing House, 1992.

Knudson, Jerry W. "Late to the Feast: Newspapers as Historical Sources." In American Historical Association Perspectives (October 1993); Internet. Available at http://www.historians.org/perspectives /issues/1993/9310/9310ARC.cfm. Accessed on 13 March 2013.

Lahiri, Shampa. Indians in Britain: Anglo-Indian Encounters, Race and Identity 18801936. London, Frank Case, 2000.

Larkin, Felix M. "Arthur Griffith and the Freeman's Journal. Irish Journalism Before Independence: More a Disease than a Profession. Manchester: Manchester University Press, 2011.

Legg, Marie-Louise. Newspapers and Nationalism: The Irish Provincial Press, 18501892. Dublin: Four Courts Press, 1999. 
Lowry, Donal. "Nationalist and Unionist Responses to the British Empire in the Age of the South African War." In Simon Potter, Reporting the British Empire, c. 1857-1921. Dublin: Four Courts Press, 2004.

. The South African War Reappraised. Manchester: Manchester University Press, 2000.

MacMunn, Lieutenant General Sir George. The Martial Races of India. London: Sampson, Low, Marston and Company, Ltd., 1933.

Mansergh, Nicholas. The Prelude to Partition: Concepts and Aims in Ireland and India. Cambridge: Cambridge University Press, 1976.

Maume, Patrick. The Long Gestation: Irish Nationalist Life, 1891-1918. Dublin: Gill \& Macmillan, 1999.

Maye, Brian. Arthur Griffith. Dublin: Griffith College Productions, 1997.

McCracken, Donal P. The Forgotten Protest: Ireland and the Anglo-Boer War. Belfast: Ulster Historical Foundation, 2003. First published Johannesbuurg and Capetown: Perskor Publishers. 1989.

. The Irish Pro-Boers 1877-1902. Johannesburg and Capetown: Perskor, 1989.

McGovern, Bryan P. John Mitchel: Irish Nationalist, Southern Secessionist. University of Tennessee Press, 2009.

Meehan, Ciara. "The Prose of Logic and Scorn: Arthur Griffith and Sinn Fein, 19061914. Irish Journalism Before Independence: More a Disease than a Profession. Manchester: Manchester University Press, 2011.

Morgan, Kenneth O. Kenneth O. Morgan, "The Boer War and the Media.” Twentieth Century British History, Vol. 13, No.1, 2002.

Mukherjee, Prof. Harida and Prof. Uma Mukherjee. "Bande Mataram" and Indian Nationalism (1906-1908). Being a study in the ideas of India's First Freedom Movement based on those rare editorial articles of Sri Aurobindo and Bepin Chandra Pal which first appeared in the famous Bande Mataram daily between 1906 and 1908. Calcutta: Firma K.L. Mukhopadhyay, 1957.

. Sri Aurobindo's Political Thought (1893-1908). Calcutta: Firma K.L. Mukhopadhyay, 1958.

Munter, R. L. A Hand-List of Irish Newspapers, 1685-1760. Cambridge: Cambridge University Press, 1967. 
North, John S. The Waterloo Directory of Irish Newspapers and Periodicals, 1800-1900. Waterloo: North Waterloo Academic Press, 1986.

Novick, Benjamin Z. "DORA, Suppression, and Nationalist Propaganda." In New Hibernian Review. Vol 1, No. 4, Winter 1997, 41-57.

O’Hegarty, P.S. Sinn Féin: An Illumination. Dublin: Maunsel \& Co., Ltd., 1919.

O’Malley, Kate. Ireland, India and Empire: Indi-Irish radical connections, 1919-64. Manchester: Manchester University Press, 2008.

Omissi, David and Andrew S. Thompson, Eds. The Impact of the South African War. Houdsmills, Basingtoke, Hampshire: Palgrave, 2002.

Omissi, David. "Some Perceptions of Race and Empire." The Impact of the South African War. Houndsmills, Basingtoke, Hampshire: Palgrave, 2002.

Oram, Hugh. The Newspaper Book: A History of Newspapers in Ireland, 1649-1983. Dublin: MO Books, 1983.

Pakenham, Thomas. The Boer War. New York: Random House, 1979.

Potter, Simon. News and the British World: The Emergence of an Imperial Press System, 1876-1922. Oxford: Clarendon Press, 2003.

. Newspapers and Empire in Ireland and Britain: Reporting the British Empire, c. 1857-1921. Dublin: Four Courts Press, 2004.

Rafter, Kevin, Ed. Irish Journalism Before Independence: More a Disease than a Profession. Manchester: Manchester University Press, 2011.

Regan, Jennifer M. Cosmopolitan Nationalism in the Victoria Empire: Ireland, India, and the Politics of Alfred Webb. Houndmills, Basingstoke, Hampshire: Palgrave MacMillan, 2009.

. "We Could Be of Service to Other Suffering People." In Victorian Periodicals Review. Volume 41, Number 1. Spring 2008.

Rosenkranz, Susan. "Breathing Disaffection: The Impact of Irish National Journalism on India's Native Press," in Southeast Review of Asian Studies (SERAS), 2005.

. "Publish or Perish: The Role of the Native Press in Promoting National Identity in Ireland and India," in Ireland and India: Colonies, Culture, and Empire. Irish Academic Press, Ltd., 2006. 
Roy, Somnath. "Repercussions of the Vernacular Press Act, 1878." Journal of Indian History. No. 135, Vol. XLV, Part III, December 1967.

Silvestri, Michael. Ireland and India: Nationalism, Empire and Memory. Palgrave Macmillan, 2009.

. "The 'Sinn Fein of India': Irish Nationalism and the Policing of Revolutionary Terrorism in Bengal, 1905-1939.” Journal of British Studies. October, 2000.

Streets, Heather. Martial Races: The Military, Race and Masculinity in British Imperial Culture. Manchester: Manchester University Press, 2004.

Sundaram, Chandar S. "Treated with Scant Attention": The Imperial Cadet Corps, Indian Nobles, and Anglo-Indian Policy, 1897-1917.” In Journal of Military History. Volume 77.1, 41-70.

Tahmankar, D.V. Lokamanya Tilak: Father of Unrest and Maker of Modern India. London: John Murray, 1956.

Van de Ven, Hans. "Robert Hart and Gustav Detring during the Boxer Rebellion." Modern Asian Studies, Vol. 40, No. 3. Jul., 2006.

Wilde, Richard H. "The Boxer Affair and Australian Responsibility for Imperial Defense." In Pacific Historical Review. Vol. 26, No. 1. (Feb., 1957), 51-65.

Wollaeger, Mark. "Seduction and Estrangement: World War I Recruiting Posters and the Politics of Ulysses." Internet. Available at http://hjs.ff.cuni.cz/archives/v2/ wollaeger/index.htmlhttp://hjs.ff.cuni.cz/archives/v2/wollaeger/index.html. Accessed on 26 February 2013.

Wolpert, Stanley. A New History of India. New York: Oxford University Press, 2000.

. Tilak and Gokhale: Revolution and Reform in the Making of Modern India. Berkeley: University of California Press, 1962. 


\section{VITA}

\section{SUSAN ANN ROSENKRANZ}

\section{Education}

Ph.D., History, Florida International University History (August 2013)

Dissertation: To Hold the World in Contempt: The British Empire, War, and the Irish and Indian Nationalist Press, 1899-1914. Dr. Rebecca Friedman, Chair.

MA, History, Florida Atlantic University, 2005

Thesis: Four Hostile Newspapers: The Role of Bal Gangadhar Tilak and Arthur Griffith in Constructing a National Identity in India and Ireland. Dr. Heather Frazer, Thesis Advisor

Bachelor of Arts, Theatre, Florida State University, 1974

\section{Teaching Experience}

2011-Present Graduate Teaching Assistant, Florida International University World History; Western Civilization: Modern Europe

2005-2012 Public School Teacher, Coral Glades High School, Coral Springs, Fl. Courses: World History; Government and Economics; Drama I, II, III, IV; Introduction to Film; Mass Media; French I Teaching Awards: 2009, 2010

2004-2005 Adjunct Professor, Florida Atlantic University (Dept. of Communications) Courses: Introduction to Media Studies

2003-2005 Graduate Teaching Assistant, Florida Atlantic University Western Civilization; World History

\section{Other Professional Experience}

2003-Present Public history documentarian

1984-2003 Freelance writer/producer for broadcast and cable clients, including HBO, CBS, and National Geographic

\section{Grants and Fellowships}

Southeast Conference of the Association for Asian Studies Travel Award, 2005 Levenson Chair in Asian Studies Grant, 2005

FAU Graduate Fellowship for Academic Excellence, 2004

John O'Sullivan Travel-to-Research Grant, FAU Department of History, 2004

FAU Graduate Grant Committee grant for thesis research, 2004

FAU Graduate Grant Committee travel grant: Conference; Galway, Ireland, 2004

\section{Awards and Honors}

SEC/AAS Graduate Student Paper Prize - Honorable Mention, 2005

Frances Edelman Award for Teaching Assistant of the Year (History), FAU, 2004

Super Graduate Assistantship, FAU Department of History, 2004 


\section{Publications}

2005 "Publish or Perish: The Role of the Native Press in Promoting National Identity in Ireland and India," in Ireland and India: Colonies, Culture, and Empire (Irish Academic Press, Ltd., 2006

2005 "Breathing Disaffection: The Impact of Irish National Journalism on India's Native Press," in Southeast Review of Asian Studies (SERAS), 2005.

\section{Presentations}

2013 "The Perfect Place to Become Violent: The Playboy Riots in Early Twentieth Century America." Presented at American Conference of Irish Studies, South; Georgia Southern University

2005 "Breathing Disaffection: The Impact of Irish National Journalism on India's Native Press," Presented at Southeast Conference for Association of Asian Studies, University of Kentucky

2004 "Publish or Perish: The Role of the Native Press in Promoting National Identity in Ireland and India." Presented at the Fourth Annual Conference on Colonialism, National University of Ireland, Galway

\section{Public History Documentaries - as Writer, Director, and Producer}

2009 The Jaffe Center. The Jaffe Center houses an internationally acclaimed collection of artist's books, in a new wing of the FAU Library.

2003-05 Arthur and Mata Jaffe Collection: Books as Aesthetic Objects.

1992-94 Circus of Hope: The Story of the Belfast Community Circus School. Documentary set against the background of marching season in Belfast. Filmed entirely on location in Northern Ireland, before the IRA ceasefire.

\section{Professional Memberships/Affiliations}

American Conference for Irish Studies

American Historical Association

North American Conference on British Studies

Southeast Conference, Association for Asian Studies

Phi Alpha Theta, Florida Atlantic University chapter: Vice President, 2003

Writers Guild of America, East (Inactive)

\section{Courses Prepared to Teach}

Survey courses: World History; Western Civilization; Modern Europe Non-Western History: Modern India

European history: Modern Europe; Nineteenth Century Europe; 20th Century Europe to WWI; British Empire; Modern Britain; Modern Ireland

Film and Media: Intro to Media Studies, Intro to Film 